Western University

Scholarship@Western

Digitized Theses

Digitized Special Collections

1983

\title{
Food Resource Utilization By Five Species Of Benthic Feeding Fish In Passamaquoddy Bay, New Brunswick
}

John Stevenson Macdonald

Follow this and additional works at: https://ir.lib.uwo.ca/digitizedtheses

\section{Recommended Citation}

Macdonald, John Stevenson, "Food Resource Utilization By Five Species Of Benthic Feeding Fish In Passamaquoddy Bay, New Brunswick" (1983). Digitized Theses. 1239.

https://ir.lib.uwo.ca/digitizedtheses/1239

This Dissertation is brought to you for free and open access by the Digitized Special Collections at Scholarship@Western. It has been accepted for inclusion in Digitized Theses by an authorized administrator of Scholarship@Western. For more information, please contact tadam@uwo.ca,

wlswadmin@uwo.ca. 
The author of this thesis has granted The University of Western Ontario a non-exclusive license to reproduce and distribute copies of this thesis to users of Western Libraries. Copyright remains with the author.

Electronic theses and dissertations available in The University of Western Ontario's institutional repository (Scholarship@Western) are solely for the purpose of private study and research. They may not be copied or reproduced, except as permitted by copyright laws, without written authority of the copyright owner. Any commercial use or publication is strictly prohibited.

The original copyright license attesting to these terms and signed by the author of this thesis may be found in the original print version of the thesis, held by Western Libraries.

The thesis approval page signed by the examining committee may also be found in the original print version of the thesis held in Western Libraries.

Please contact Western Libraries for further information:

E-mail: libadmin@uwo.ca

Telephone: (519) 661-2111 Ext. 84796

Web site: http://www.lib.uwo.ca/ 


\section{THESES CANADIENNES SUR MICROFICHE}

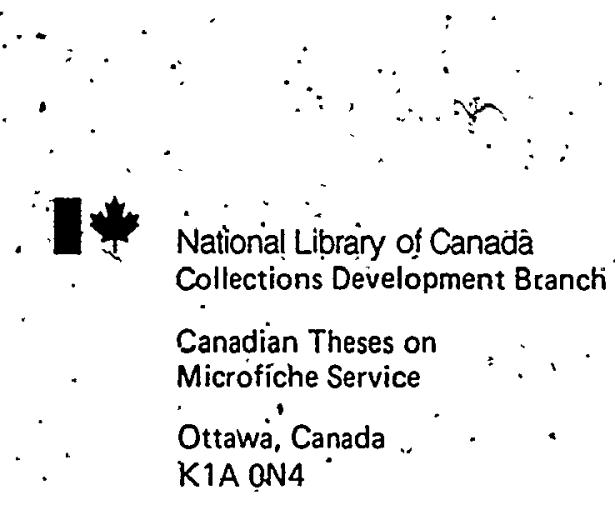

\section{Bibliothèque natıonale dú Canada \\ Direction dú développement des collections}

Service des thèses cąhadiennį̣s surmicrofiche
NOTICE

The quality of this microfithe is heavily dependent upon the quality of the original thesis submitted for microfilming. Every effort has been made to ensure. the highest quality of reproduction possible.

If pages are missing, contact the university which - granted the degree.

Some pages may have indistinct print especially if the original pages were typed with a poor typewriter ribbon or if the university sent us a poor photocopy.

Previously copyrighted materials ljournal articles, published tests, etc.) are not filmed.

Reproduction in full or in part of this film is governed by the Canadian Copyright Áct, R.S.C. 1970, c. C-30. Please read the authorization forms which accompany this thesis.

\section{AVIS}

La qualité de cette microfiche dépend grandement de la qualité de la thèse-soumișe au microfilmage. Nous avons tout fait poour asșurer une qualité supérieure de reproduction.

S'il manque des pages, veuillez communiquer avec l'université qui a conféré le grade.

La qualité d'impression de certaines pages peut laisser à désî́rer, surtout si les pages originales, ont été dactylographiées à l'aide d'ún ruban usé ou si l'univer sité nous a fait parvenir une photocopie de mauvaise qualitè.:

Les documents qui font déjà l'objet d'un droit d'auteur (articles de revue, examenș publiés, etc.) ne sont pas microfilmés.

La reproduction, même partielle, de ce microfilm est soumise à la Loi canadjenne sur le droit d'auteur, SRC 1970, c. C 30 . Vèuillez prendre connaissance des formules d'autorisation qui accompagnent cette thèse.

\section{THIS DISSERTATION HAS BEEN MICROFILMED EXACTLY AS' RECEIVED}




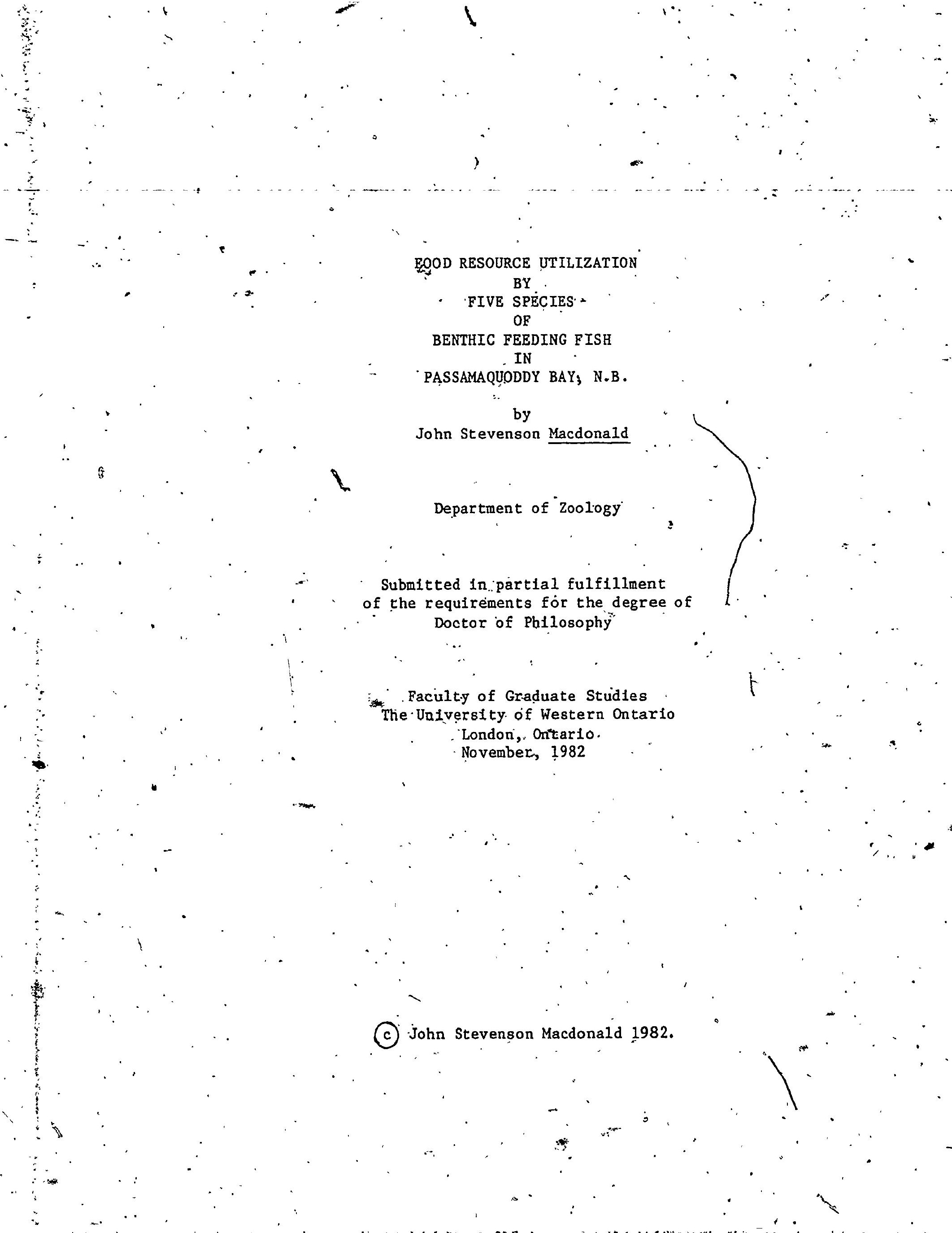


Feeding relationships of various fish spectes, and thetr relationship to the composition of the surrounding sedimenț, were observed fọ one year at two stites in the lower Bay of Fundy region. The fishes were the ocean pout (Nacrozoarces americanus), winter flounder (Pseudopleuronectes americanus), pliaice (Hippogiossoides platessoides),-cod (Gadus morhua) and witch, flounder (Glyptocephalus cynoglossus). After reducing the size' 'of the ata matrix by removing redundant variables (prey items), interspecific diet overlap and the degree to which stomach contents reflect benthic composition were assessed using discriminant functions analysis. Variables were ranked by their power to discriminate among pairwise comparisons of groups:; fish spęcies and benthic samples. Many amphipods $\infty$ were utilized to a greater extent than thelr, abundances in the sediments. would suggest. Many annelids were underut1lized. Each fish species. has. developped spectalized feeding behaviours, digestion techniques and morphologies to segregate food resources. Al.1 species tend. to increase prey intake at those places and times when berithic abundance of prey common to. their diets increases. visual predators (fiounders) show different functlonal responses towards increased prey jabundances that non-visual predators (ocean pout). In some cases dvallability is determined by prey size rather than prey abundance.:

Only a few prey speçes show benthic densitty changès as a result of predation. Benthfe populations may be held at an-early successionary, highly productive stage by extreme physicali conditions. 'Large fíctua-. tions in temperature, salinlty and current, could provide a force regulating benthic species abundance that is at least as foportant as fish predation. 
I wish to express my gratitute to the many, people who have helped at varfous stages of the research.

The staff and students of the St. Andreys Blological Station and Huntsman Marine Laboratory provided support at every stage of the thesis. Messrs. W. McMullon and C.F. Cunningham prepared many of the figures. Captains J. Allen; D. Hurley and $C_{0}$ Wright and their crews, provided bost time and helped in many other ways. Drs. K. Wațood and M: Dadswell provided laboratory and office space and a great deal of constructive criticism. The ifterest, and energy they show töwards the field of fisheries sclence" is very contagious. Dr. D. 'Wildish kindly provided. much of the trivertebrate feeding habits data." Thanks also to Joanne Powers, Dave Methven; Leslie Linkletter, Ralph Appy, Leslie Davidson and Derek. Knox for hẹlp with the sampling and the hours gre grueling microscope work. Mike Butler helped by beling one of the best expediters I know.

I would like to acknowledge and thank the many people at Western for their. help and support throughout the years." The past and present members of the colilp famlly, Graham Sudbury, Jim Carpenter, Brian Bietz, Bev. Hicks, Ke1th Somers, Brienda Goodsơn, Doug Noltie,-Greg Goff, Hélène Dupuis and simon Courtenay, have all contributed stimulating discưssion - and friendly rlvaliry: Thanks also to the staffef the computer centre for their patience: Drs. G. Wells and J. Kớl of the statistics and Actuarial Sclence Department at Western helped in designing and analysing 'this study.'. 
$\therefore$ I am grateful to the members of my committee, prs $\therefore$ H. B. Scot e; M.H.A. Keenleyside and s. Singh for their patience, and encouragement: A very special thanks to Dr. R. H. Green, not only my guiding light and source of energy but also al very close friend.

I am grateful to Ý one Pepper for typing the manuscript on such short. notice, Rick van Vloten; who is still a marine blologist,at heart, and my. - father for proofreading the early drafts. This work was financed by N.S.E.R.C. operating and strategic grants to Dr. R.H. Green. 


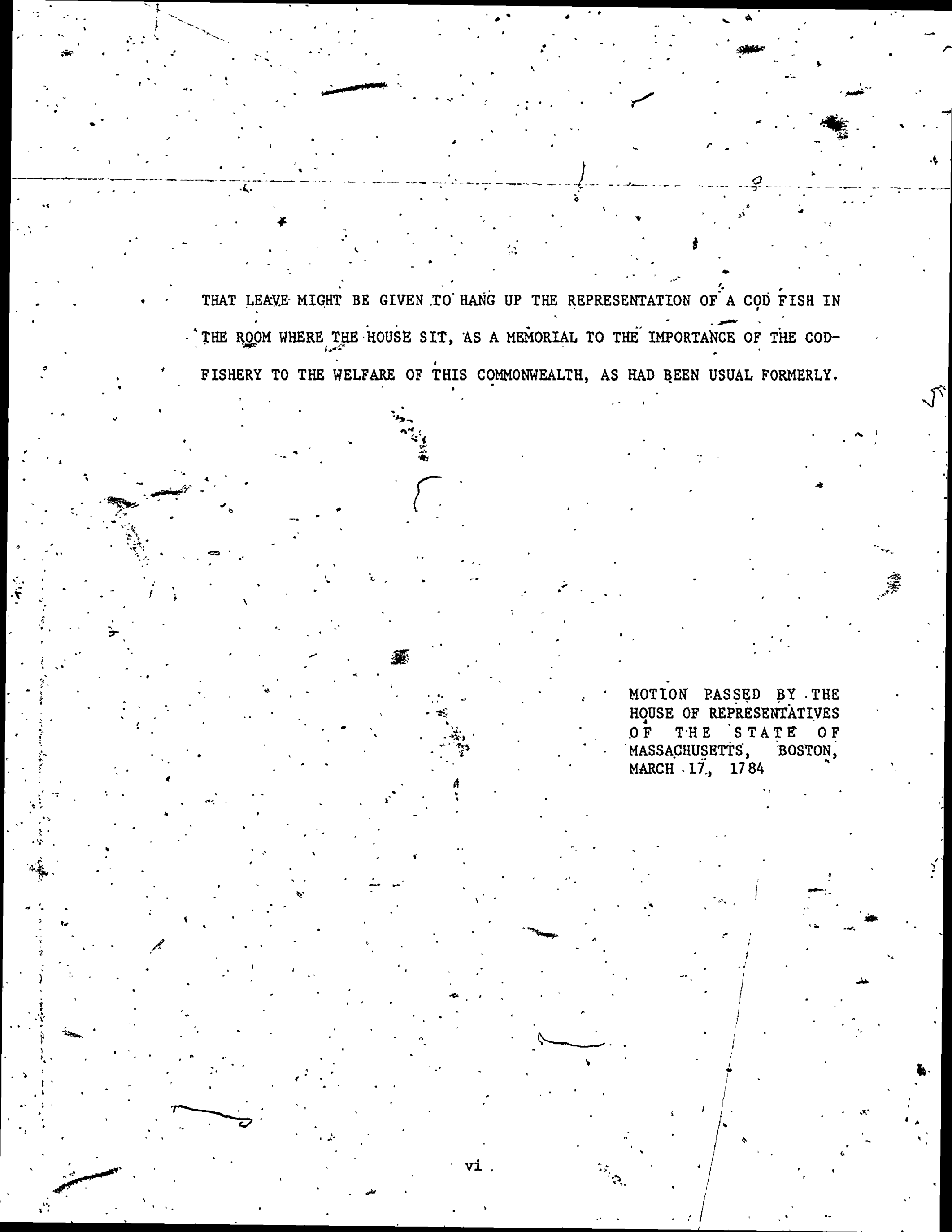


APPENDIX.III Feeding Chronology and Dally Ration

Calculations for Winter Flounder (Pseudopleuronectes americanus), Plaice (Hippoglossoides platessoides), Cod (Gadus morhua), and. Ocean Pout

(Macrozoarces americanus) with consideration of prey type

APPENDIX IV Feeding Behaviour of the Ocean Pout

- (Macrozoarces americanus) and winter

Flounder (Pseudopleurnectes

americanus) in Passamaquoddy

Bay, N.B.

APPENDIX $V$ Redundancy in. Environmental Variables

-APPENDIX VI

List of Variables Collected in the

,

Course of the Study

..........

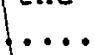

APPENDIX VII

FORTRAN" Program to calculate

Electivity Indices and Percent

Frequency of -Occurrence Data

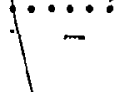

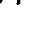

APPENDIX VIII Spietial and Temporal Variations in

Densitles of Variables in Each

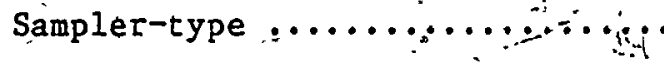

APPENDIX IX FORTRAN Program to calculate $95 \%$

Confidence El tpses Around Group

Centroids

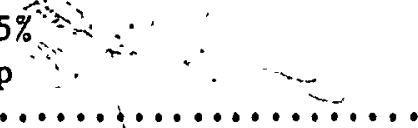

VITA

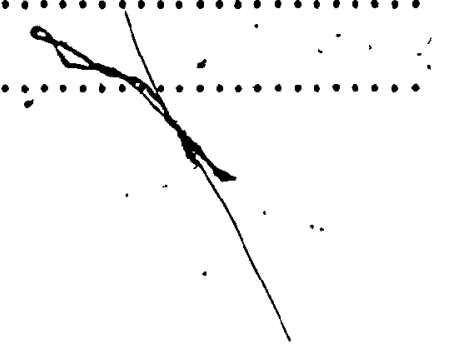


LIST OF TABLES

Table

Description

Page

2.1 Fish sizes and collection times

11

2.2 Discriminant function coefficients

20

3.1 Invertebrate life history data

$3 \dot{4}^{2}$

3.2 Benthic variables that discriminate between sites ....... 46

3.3 Benthic variables that discriminate among times $\ldots \ldots \ldots \ldots, 48$

3.4 Eigenvalues among fish diets and benthic

$\therefore$ composition

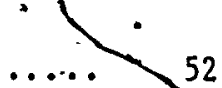

3.5 Variables ranked by their ability to discriminate among sampler-types

52

3.6 Eigenvalues among diet composition of each fish species

62 
LIST. OF FIGURES

Figure

Description

Page.

2.1 Sediment Analysis

2.2 Data Cube

2.3 Data Matrix

Discriminant analysis using different date types

Mean species diversity in each sampler-type at.each , sampling time.

3.2 Mean number of items in each sampler-type at each

sampiing time

3.3 Percentage of 1 tems in each of three major phyla

3.4 Mean size of three common benthic species with time

3.5 Three dimenstonal separation of benthic siample discriminant scores

3.6. Reference map for Figure 3.5

3.7 Two dimensional separation of discriminant scores

from all sample $\vec{r}-t y p e s$ at each-collection time

3.8 Predator functional responses to different densitles of prey

3.9 Two dimensional separation of discriminant scores

from all fish specles at each collection time

3.10. Mean'mediment depths of 12 types of benthic

inyertebrates 
In the past few years many researchers have emphasized the Importance of the benthos in understanding the dynamics of marine ecosystems. Models of energy flow through the benthos show the need for knowledge of trophic interrelationships between demersal fishes and their benthic prey (Téal 1962; Odum 1971; Sțeele 1974; Arntz 1975, 1978c; Mearns and Young 1978; 'Prince et a1 1979). 'In particular we need to know: what macrobenthic items are tmportant for fish food and at what rate they are assimilated, how benthic composition and production affect the production of fishes and in return is the benthos modifled by the predation pressure - of the fishes, and how effectively and by what mechanisms fishes partition their resources (Mills 1975). Principles used in studies of this nature must be based on theories of competition and niche space as these theories are major structuring forces in animal communties (Schoener 1975; Pianka 1978; Ricklefs 1979).

Information about food habit and food resource partitioning by northwestern Atlantic demersal fishes has been collected for more than twentyfive years (Powles 1958; Tyler 1971, 1972; DeGroot 1971; Frame 1974; Bowman 1977, 1980, 1981a, 1981b; Langton and Bowman 1980, 1981;。 Wa1wood et a1 1979): However, food habits of most fish species vary with spatial and temporal changes in the avallable food resources. Knowledge of the benthic composition within the fishes' foraging area is necessary to quantitatively appraise the degree to which fish "select" (this is not meant to imply that fishes select in any deliberate sense of the word) their prey (Ivlev 1961), and to test optimal foraging and niche volume theories. Predictions of degree of niche overlap and optimal foraging 


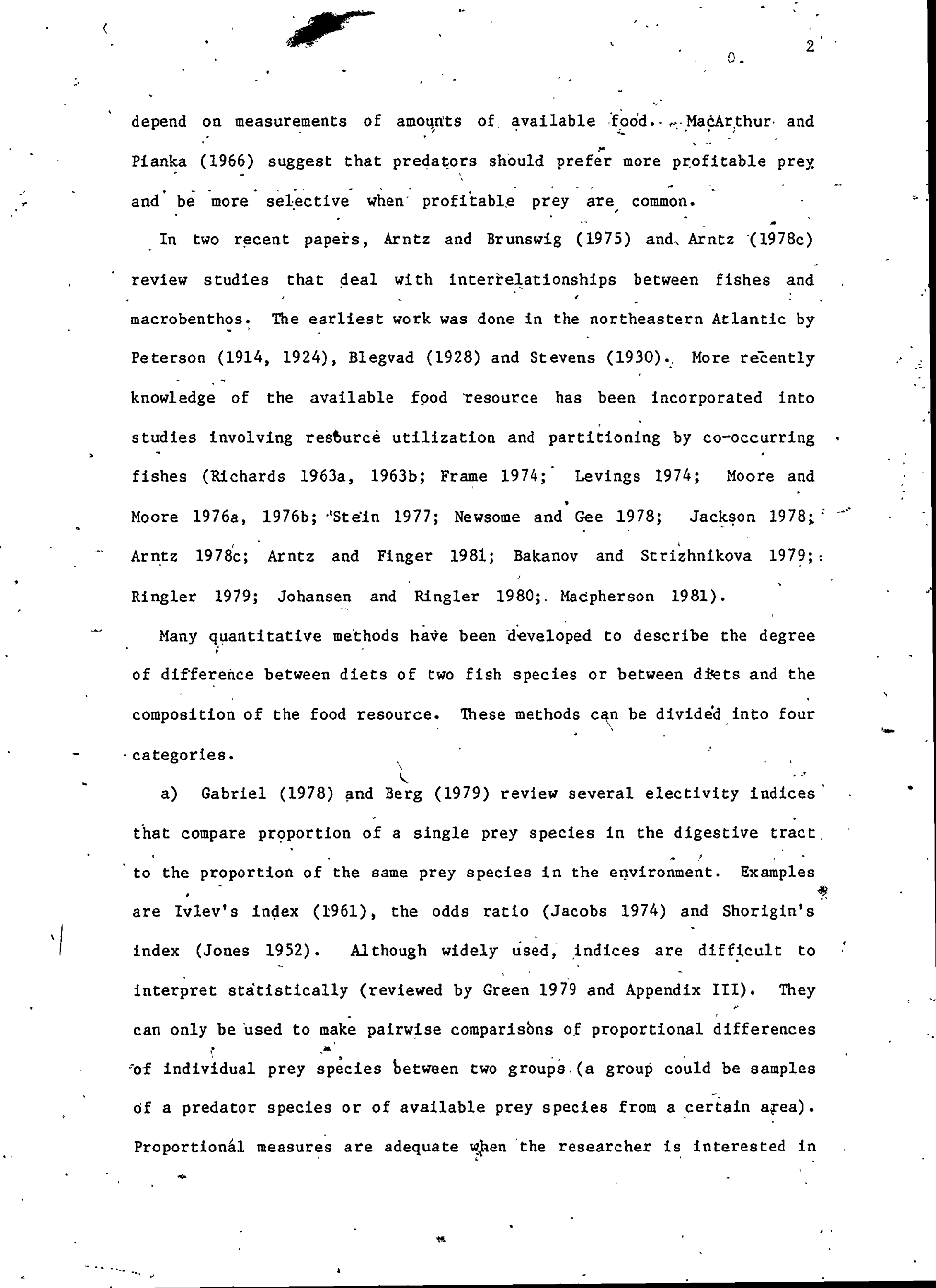


answering questions about fish" feeding "selectivity". 'However,'.. more recently there has been an additional tnterest" in daily rates of assimilation in order to determine what effect fish predation has on the population structure of the food source (Mills 1975). Therefore; diet overlap among predators, and comparisons with the food source, should consider actual préy species abundances. :

b) Feinsinger et al (1.981) "revièw the development of sample similarity indices (eg. Colwel1-Futuyma method 1971): They differ from electivity indices' in that all prey specles are comparied between two" groups at once. The index measures the area of intersection between two frequency distributions. They share many of the disadvantages mentioned in. category a).

c) Correlation coefficients have been applied to determine whether there is a significant relationship, between ranked prey items in the diets of two predators (Fritz 1974). :This method is an improvement on methods already mentioned in that it dọes. allow the "establishment of probability estimates and it can be used with actual rather than proportional measures of prey abundance. However, none of the above methods estimates the variation of prey species abundance within.each predator species, or, the environment (ie. no within-group. error. estimation). 'Other people have recognized this problemi. Horn (1966) noted: "Indices..... are only approprtate in situations in' which there is Implicit confidence that the proportions of Items in each category are adequately characterized." Frame (1974), when comparing percent diet overlap measures between winter flounder stomachs and benthlc samples, also" compared overlap within stomachs and withln grabs. "There were greater overlaps, within g̈rabs and stömachs "ṭan betceen" them. 
- d) Analysis of variance (ANOVA) is more appropriate when comparing within group to among group variation. When there are multiple dependent variables (fe. prey speciēs) a multivarlate ANÓd (MANOVA) should be used. A MANOVA can consider any number of groups and will determine significance levels of estimates of the group means. Multi-factor MANOVAs can be used to test food composition differences among fish sizes, site and sampling times as..werl as differences among predator $\therefore$ species. However, few researchers on fish. feeding have used multivariate techniques to compare diets. Ross (1977) measures similarity among congeneric searobins using cluster analysis to detect group structure based on diets. Ellison (1978) and. Desselfe et al (1978) use discriminant analysis and MANOVA techniques to test for significant predator group differences. In their studies varlable loadings on discriminant functions are used to isolate which variables differ among groups. There are alternate ways to isolate variables which discriminate amoing groups.(Jancey.1979).: These will be discussed later. : s.

Crow, during a recorded discussion at the 1978 Fish Food Habit' Workshop, has critized Ellison for violating the assumptions of parametric discriminant analysis. - However, Green'(.1979) and Klecka (1975) discuss the robustiness. of discriminant analysts and other parametric statistics to many of the violations of parametrfe assumptions.: This will be, discusséd later in greater depth.

This study is an extension of a five year survey of the distribution of fishes in the lower Bay of Fundy and Passamaquoddy Bay (Appendix I). It attempts to determine what effect temporal and spatial changes of the macrobenthos will have on the food utilization and partitioning by the demersal fish community. The objectives of the thesis can be presented 
as four hypotheses:

1. Five fish species, winter flounder (Pseudopleuronectes americanuś), plaice (Hippoglossoldes platessoldes), witch flounder (Glyptocephalus cynoglossüs), ocean pout (Macrozoarces americanus) and cod (Gadus mgrhua) show no "preference". for prey species: Food composition In the gtomptis a random sample of the composition of the benthos:

2. Any öbserved "preference" for food will not change with a spatial or temporal change in the benthic composition.

These hypotheses direct thoughts about the correlation between the $\therefore$ benthos and patterns of food utilization by fishes. If benthic composition totally dictates the food camposition in fishes' stomachs, hypothesis 1 , will be accepted and spatial-temporal changes in the bottom fauna will merely cause the fishes' food hablts to change accordingly: If, however, fishes do select food items preferentially then the consequences of the selection process will not be known untll the flshes' feeding reactions to a changing benthic composition are, determined.

3. All fish species consume the same food at the same space-time combination. Therefore, there is no niche, separation among the - predators, along the prey abundance dimensions.

4. If niche separation does occur then the niche "positions"- of all predator species remain the same despite spatial and temporal chänges in the benthos.

3 
- The importance that spatial and temporal variation. in size distributions of common benthic prey species has on patterning food utilization by fishes is also considered. $\sim$

These hypotheses are important in guiding the direction of data exploration. It is not the purpose of this thesis to test them rigidly at a specified probability Ievel. Rather than a strict decision making approach of the hypothesis testing procedure, a scientific inference $\therefore=$ -approaich is taken in which evidence is gathered to support"or refute each hypothesis. The complexity of the system is such that formal statistical tests of the hypotheses would probably not be possible in any case. Exploration of these hypotheses has génerated many more hypotheses. Some of them are explored in the attached appendices. Appendix I is a summary of a five year survey of the distribution of fishes in the lower Bay of Fundy region. Only two of the fifteen stations included in Appendix I were used in the rest of the-thesis but all the information was used to choose five syntopic fish specles that would be abundant throughout a one year sampling pẹriod.

Variation in the digestion pattern of different prey. is an important variable in evaluating diet consurtion rates and food préference of wild fishes. The degree to which differential digestion and/or evacuation of prey 'types influence the researcher's perception of diet composition is presented in Appendix II, as are models used to describe gastric evacuation.

Appendix III describes diel feeding periodicity and the amount of food consumed daily by the fishes in this study. Different feeding times among fish species may; serve to reduce interspecific competition. 
Appéndix IV describes the methods by whych winter flounder and ocean' pout search and capture prey. Different hunting imethods among fish species may be, one of , the factors linvolved in resaurce diviston. Appendix $v$ examines the information redundancy associated with three measurement-variables: prey abundance, p̈rey wệght and percent frequency of occurrence.

At the time of writing all but Appendix III had beẹn submitted for publication. Appendices II; IV and V have been accepted. The data collection, analysis, Interpretation and "presentation was the sole responsibility. of the $\mathrm{PhD}$ applicant in alt but Appendix $I$. The first three of five years data collection in Appendix I was made by the coauthórs ișted.

- The reader should be familartwith the contents of the first refive. appendices', before proceeding. 


\section{MATERIALS AND METHODS.}

2.1 Study Sites

With the exception of the fish distribution portion of this thesis (Appendix I), all fish and-benthic samples were collected along $21.6 \mathrm{~km}$ transects; one in Passamaquoddy Bay (A) and the other in the Bay of Fundy ( $B$; Appendix I - Fig.1). The sites were 55 and $80-m$ deep respectively and were relocated each collection period using a depth finder and radar. The añnual temperature range was is: less at site B but the salinity was generally higher (Appendix I Fig.2). Site A had stronger currents, particularly at the southerly end, due to the tidal flushing effects of Passamaquoddy Bay. Sediment samples taken with a PONAR grab in July 1979 at site B and the northwestern half of site $A$ were composed of silt and clay. The other half of site $A$ is composed of sand (Fig.2.1). Both sieve and hydrometer techniques were used to analyse the sediments (Bowles 1970). Sediment sanples were subjected to $550^{\circ} \mathrm{C}$ temperatures for $2 \mathrm{~h}$ to burn off the organic fraction. "Samples from both sites, consisted of approximately $7 \%$ organic material. Site $A$ was the same site sampled by Tyler (1971) during 1965 and .1966. . $^{\circ}$ Data Collection.

Fishes were collected using a $3 / 4-35$ shrimp trawl constructed of $3.8 \mathrm{~cm}$ stretch mesh nylon with a $15.5 \mathrm{~m}$ head rope. The negt was towed with the 150 h.: p., 14 m stern traler Pandalus II. Repeated tows were made along each transect once a month for 7 months during

the period of July 1979 to June 1980. (Table 2.1). Site A was not samplêd during December 1979 because of the proximity of lobster trap 11nes. Within "3 days of each fish collection, 10 , benthic 
1 $\therefore \quad \div$. $\because$

$\therefore$

$:$
$=$

- FIGURE 2.1 - Grain size distribution of benthic sediments: taken from site $A$ and $B$. Site $B$ moles are consistent along the transect (rife r-to map," Fig. I-1):" Sediment "samples from the northern end of site A have a similar grain size -distribution to "those from site. B: They -get

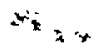
progressively coarser approaching Deer Ts land. $\therefore \div=-\because-$ Site $A$ Site B 


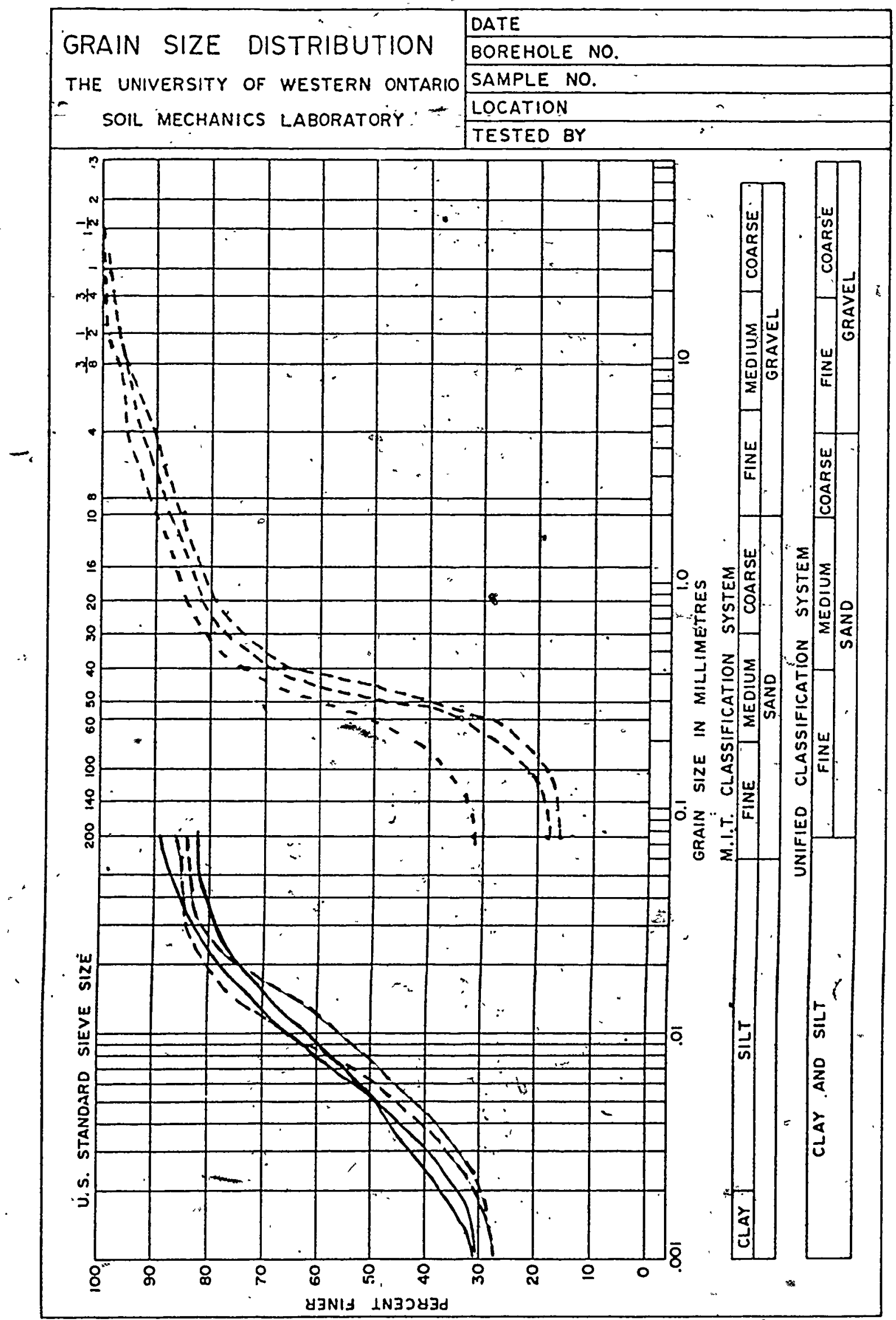


$\gamma_{1} \ldots$

11

TABLE 2.1 Summary, of numbers $(n)$, mean lengths $(\bar{X} L, c m)$, standard deviations of lengths (S.Dev), age ( $\bar{X}$ age, years) and sex of all fish -species, collected at each sampling time. Fish length range within each. fish species was minimized and an; , attempt was made to collect 10 of each "fish species att ea ch site and time. This was not always possible. Each male fish was given a.value of zero and each, female fish a value. of one. The means of, all values for each specters are presented to indicate the proportion of hales and females collected at each site and time. 
TABLE 2.1

SAMPLINYG DATES

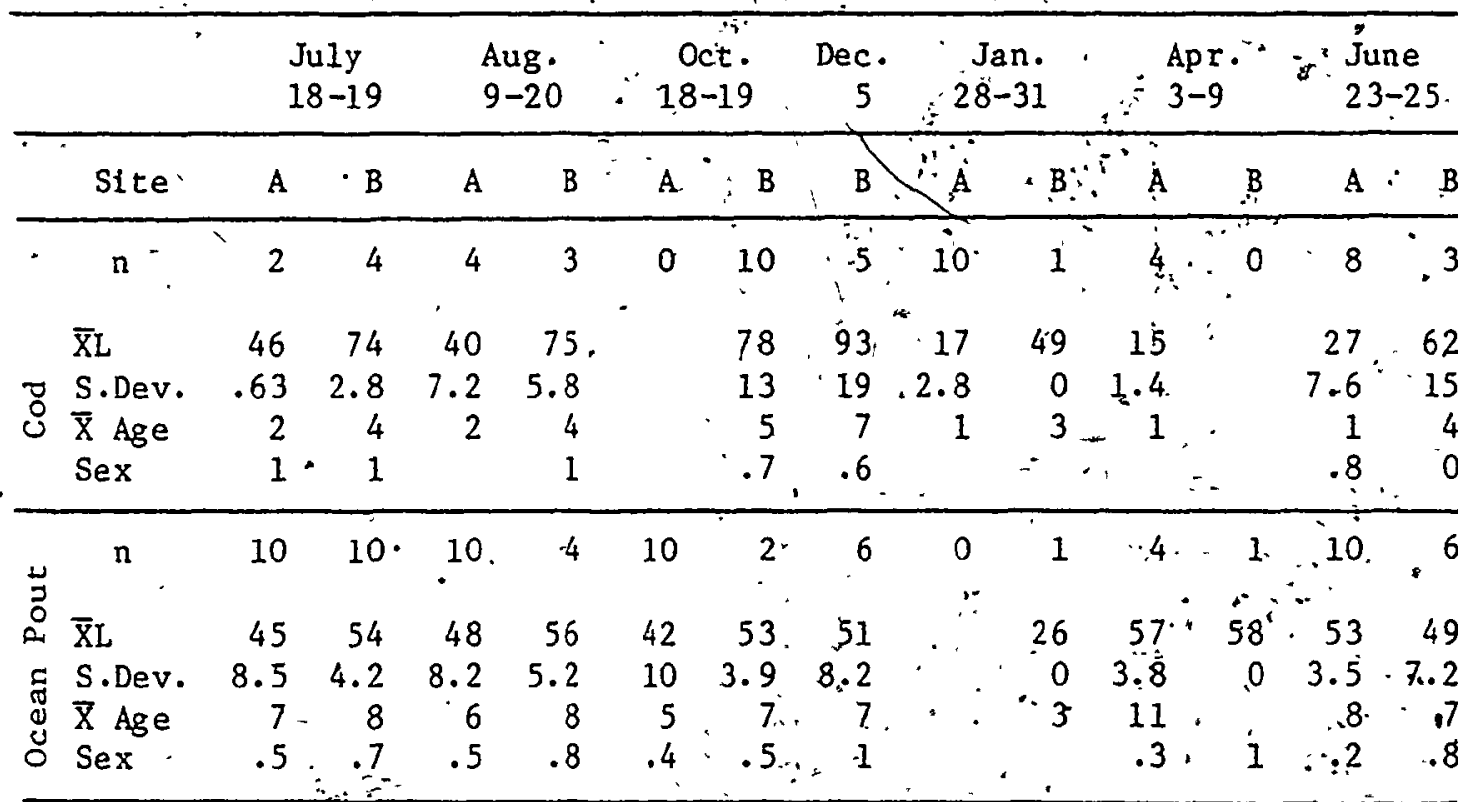

$4 \pi \quad 10 \quad 2,10-3 \quad 10 \quad 4 \quad 10,10 \% 10: 10-10$ io 4 .

$\begin{array}{llllllllllllllll} & 32 & 37 & 34 & 40 & 34 & 34 & 38 & 32 & 25 & 26 & 28 & 27 & 28 & 38\end{array}$

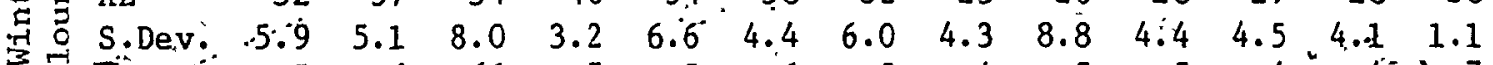

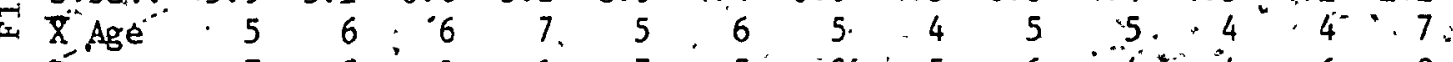

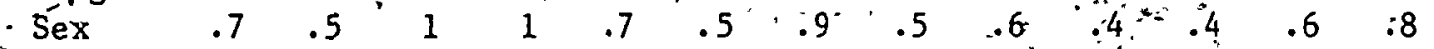

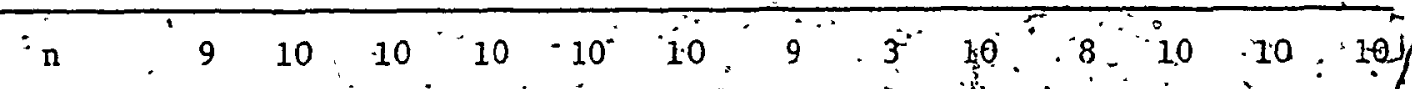

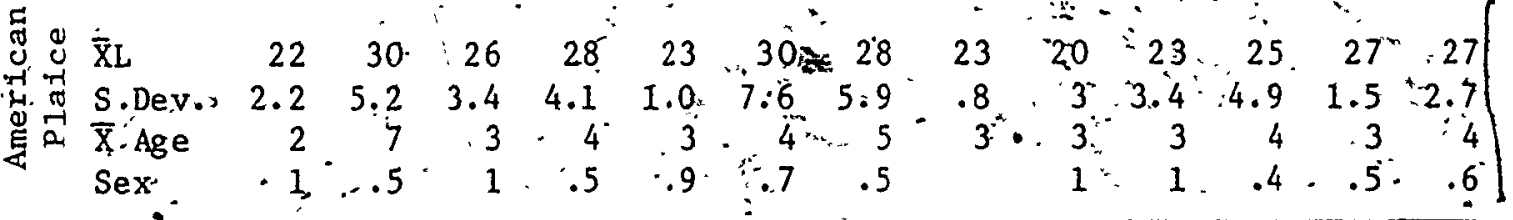

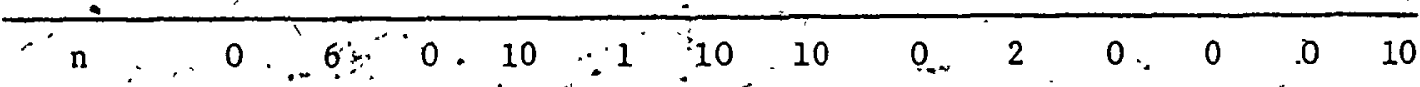

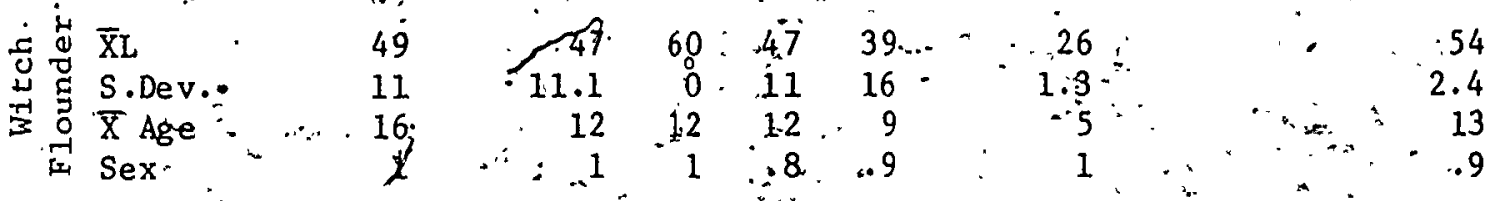


samples were taken at each site from the RV Miss Michelle using a PONAR grab. Eạch grab sampled a $23 \mathrm{~cm}^{2}$ area. If sufficient pumbers were captured, 10 winter flounder, cod, plaice, ocean pout and witch flounder were selected. Witch flounder were not çaught at ste A. Total length (to the nearest $\mathrm{cm}$ ), weight - (to the nearest $g$ ) and sex estimates were made for each specimen. To reduce the effect. of fish size on food habits the size range of fish collected within leach species was kept to a minimum (Table 2.1). Unfortunately there was a large sige variation in the cod sampled: Cod become increasingly piscivorous as they grow (Powles 1958; Arntz 1974; L L $11 y$ and Fleming 1981). This increased the "prey species variation within the cod sámples.

$*$ "Immediately after capturing the fishes their stomachs were removed and placed singly in numbered jars of $10 \%$ buffered foralin. remed and placed singly in numbered jars of $10 \%$. buffect formalin. Fn the laboratory prey species were transferred to po\% e thanol and " - iater keyed to the lowest possible taxonomic leve? (Appendix VI). Mollusk viscera were keyed when valves were not present (Appendix $\therefore$ IV) Blotted wet weight (to the nearest $0.01 \mathrm{~g}$ ) and number of each

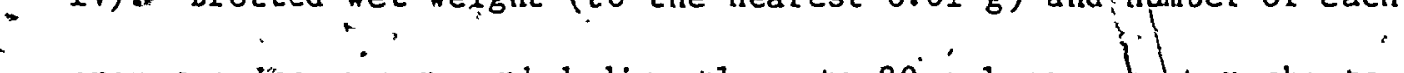
prey speciles was recorded directly onţo $80^{\circ}$, column copppter sheets.. otoliths were removed and stored $1 n$ an equal mix of glycerin and Acohol. Fishes' ages were determined by the aging sectidp of the st. Andrews' Fisheries and Oceans Laboratory (Table 2.1) $\because$ Benthic samples were washed ihrough a 1 mm screen and stored in $10 \%$ buffered formalin. Laboratory analysis of grab samples was similar to" that of stomach samples.. In addition, three. common benthic spécies (Casco bigelowi, Leptocheirus pinguis and- Yoldia sapotilla) were measured (total length). using a computer Inked 
measuring device (Tektronix 4954 digitizer). The technique described by Macdonald and Sudbüry (1982) was followed. A 2 factor analysis of variance (ANOVA) was used to test for mean length differences of each species fuetween sites and among collection times. Computing was done using the ANOVA subprogram (classical aproach) in the statistical packages for the social sciences (SPSS). on a Cyber 170 at the University of Western Ontario computer centre. To measure the depth-within-the-sediment, preferences of common benthic prey species, ten mud samples were collected with a tall Ẹckman grab (dimensions:- $14 \times 14 \times 23 \mathrm{~cm}$ ) at site A. during June 1980. The column of that resulted from each grab (approximately $10 \mathrm{~cm}$ high) was immediately sliced into five $-2 \mathrm{~cm}$ sections. Each section was sieved through a $1 \mathrm{~mm}$ screen and stored in $* 0 \%$ buffered formalin. Species were identified to their lowest taxonomic level. A one factor ANOVA. followed by an SNK multiple range test was used to examine mean depth differences among the benthic species. The " depth information was $1 n(x+1)$ transformed before the analysis to remove dependence of the varlance on the mean.

Communication. with fellow scientists and literature sources were used to estimate feeding strategies, spawning times, 1ife spans and migratory behaviour of some tof the common benthic organtsms. -

$2: 3$ Data Analysis

This was a three dimensionaldmultivarlate study where six. sampler-types (five fish spefies and the bottom grabs) were colilected from two sites at seven-times during a year (Fig.2.2): There were 217 prey or patential prey species (dependent varlables) identified from one or more of the sampler-types (Appendix VI). 
FIGURE 2.2 Data cube showing the 3 dimensional nature of this study. December-site A is:empty because lobster lines prevented sampling. Witch, flounder, were not commonly caught at site $A$ and therefore were not included in the analysis of site A.'

$$
\begin{aligned}
& G=\text { grab } \\
& F-\text { winter flounder } \\
& 0-\text { ocean pout } \\
& P-\text { plaice } \\
& C-\text { cod } \\
& W-\text { witch flounder }
\end{aligned}
$$

FIGURE 2.3 Data as they were prepared for computer analysis. Note that each of the 217 wariables (prey species) is expressed as a number and a weight. There were 527 fishes, and benthic grab samples (cases). They were divided in groups of each sampler-type at each site-time ? combination. 
16

6

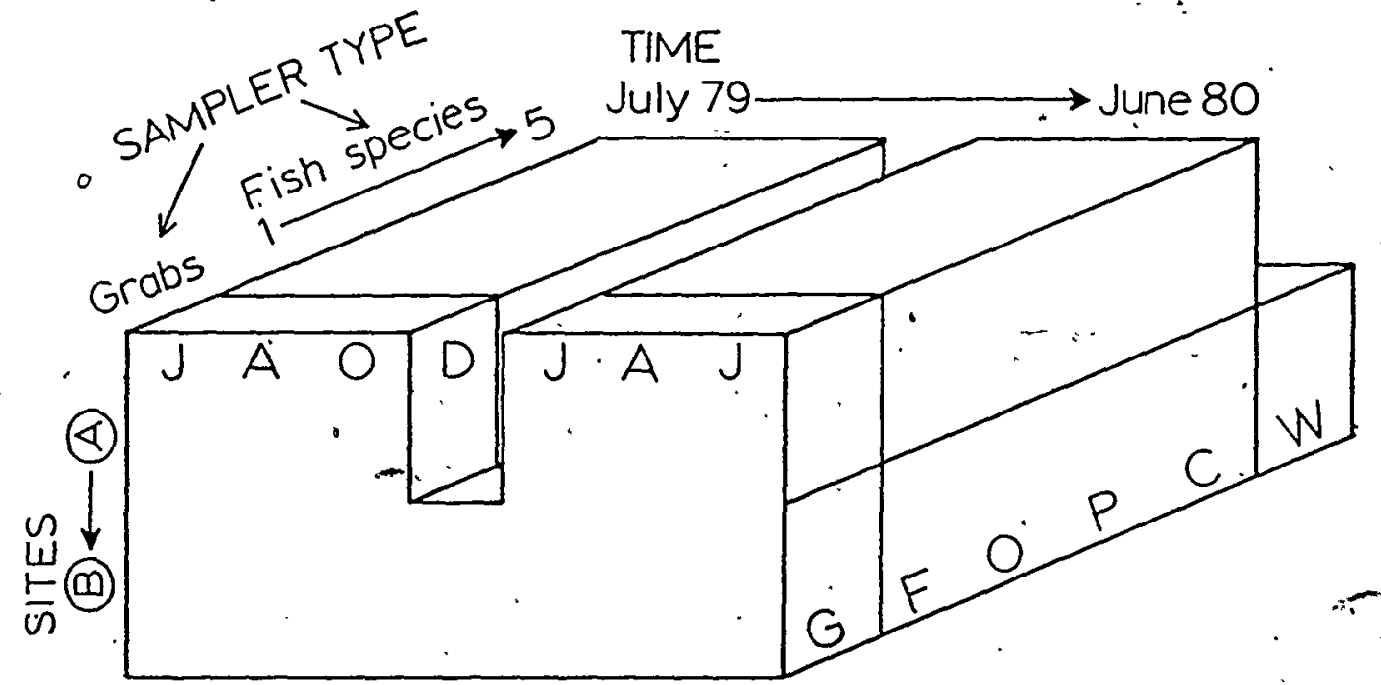

0

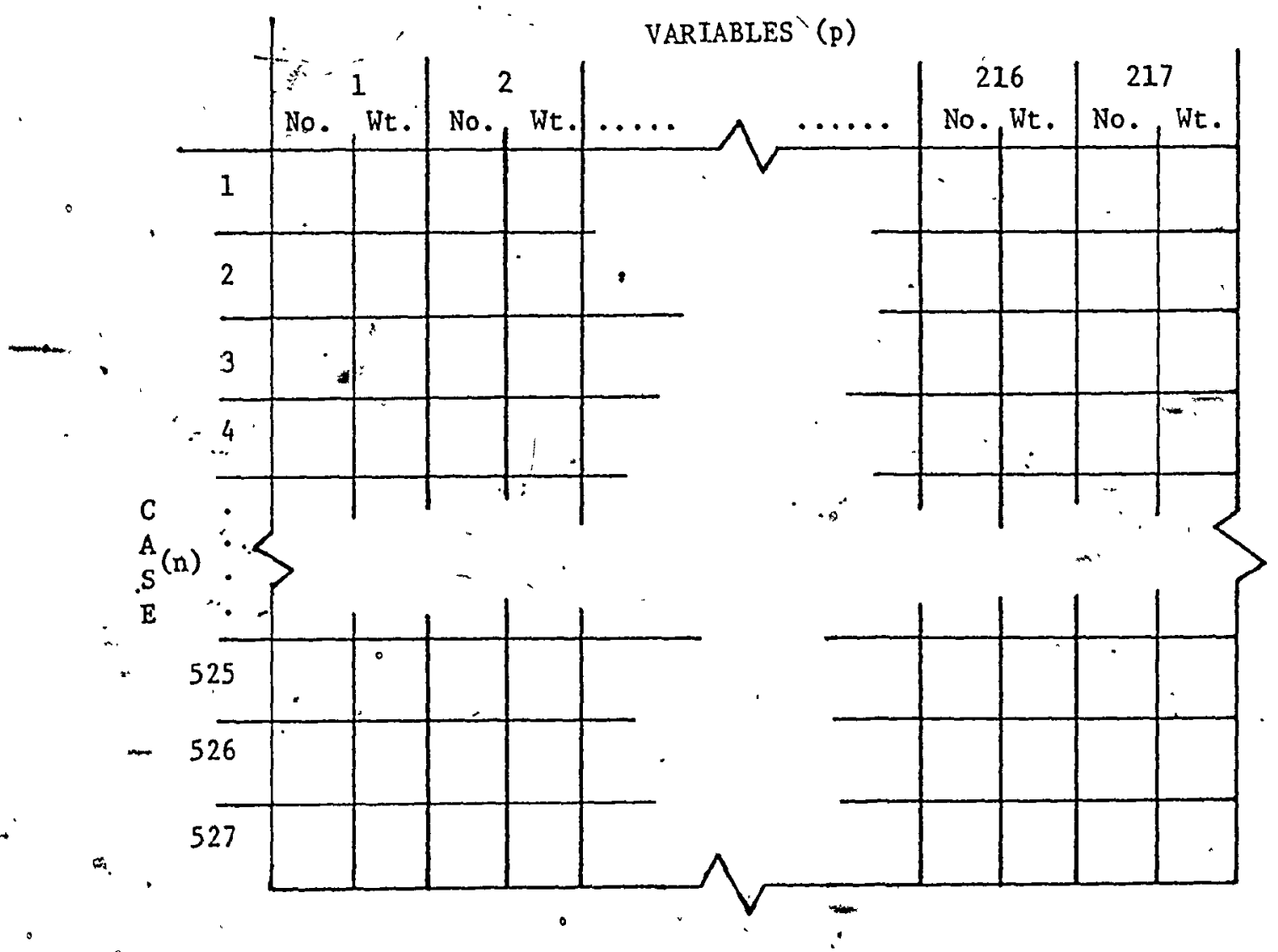


In preparation for analysis the data were stored on the disk - system of the Cyber 170 computer in a two dimensional matrix format (Eig.2:3). A matrix of this size needed to be reduced because there is usually a great deal of information redundancy when large numbers of variables are used (Green 1979). Three methods were used to reduce the size of the matrix:

a) Only number of prey measurements (not weight) were used in the analyses. Measures of number, weight and percent frequency of occurrence for a single varlable are highly correlated. Little $*$ Information is gained by using more than one measurement type. (Append $1 \mathrm{x}$ V).

b) A correlation technique was used to rank the variables (prey species) according to the additional information each one added to the entire data matrix (Green and Macdonald in prep; Orlóc1 1978 program called Rank). The variable given the lowest rank has the highest Pearson" product - moment correlatión coefficient with the - other variables. If two or more yariables are highly correlated with one another only the one with' the greatest amount of information will be used. In this manner 217 variables were reduced to 126 .

c) Vartabies that occurred in less than $2 \%$ of the 527 cases were - eliminated because they add very little information to the data matrix. This left the 74 variables that were used in the food habit - analyses (Appendix VI). They included most of the 22 principal prey of demersal fish in Passamaquoddy Bay in Tyler's (1972) study. A series of graphical techniques was used to describe spatial and temporal changes in mean abundance of the major components of the 
fishes' diets and benthIc samples. A FORTRAN program was used

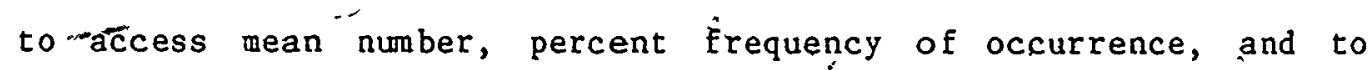
calculate Ivlev's (1961) electivity indices (Appendix VII). Electivity indices were not used in this thesis because ratio index variables (ie. number of a prey species in stomach divided by number in benthic samples) are difficult to compare statistically. For a more thorough discussion see Green (1979) and Appendices III and $v$. However, electivity indices are avallable' should they be required by the reader.

Abundance -data are generally non-normally distributed (contaglous) because of large numbers of variables with zero values in the data matrix. Many, parametric based statistical tests (eg. ANOVA, Discriminant Analysis) are robust to non-nomal distribution of variables particularly when thêre is a large error degree of freedom;(Klecka 1975; Green 1979; 1980; J. Koval per.comm•). A more serious violation occurs when the variance is heterogeneous among groups, which often results from dependence. of the variance on. the mean. This is particularly, true when sample sizes are unequal. An Ln $(X+1)$ transformation was used to remove dependence of the variance on the mean. This transformation was determined using Taylor's power law (Elliott 1977; see Appendix.V). Log transformations are commonly used when dealing with organism. abundance data to stabiliz̃e varlances and to reduce the skewness and non-additivity of varlance components (Sokal and Rolhf 1973; Marriöt 1974; Green 1979, 1980).

A three factor multivarlate analysis of variance (MANOVA) was used to test for overall significant differences among mean prey 
abundances of all site-time-sampler type groups within the data matrix. Then discriminant analysis was performed to compare benthic composition among sites and times. It was used again later, at each site-time combination to find the discriminant functions (DF), and their variable loadings, that gave the maximum separation among groups of fishes and the benthic samples. In this manner diets of. all fishes were. compared to the potential food components in the sediment. These analyses were made using SPSS at the University of Western Ontario. A portion of the differences among sampler-types, in this anaiysis, is due to the grab taking a larger number of organisms than the fishes (Fig. 3.2). However, discriminant analysis is legitimate for my purpose. "The largest discriminant function coefficients, (loadings) of the first discriminant functon of each site-time analysis were generally divided between positive and negative values (Table $2 . \dot{2}$ ). When variables with large loadings have opposite signs it indicates large: abundances in opposite groups. The first vector describes differences in benthic species proportions among sampler types as well as sample size differences (Jolicoeur and Mosimann 1959).

The series of discriminant analyses was repeated on fishes only (with benthic grab samples remaved) to give a better plcture of the .degree of feeding niche. separation that occurred apong $f$ ish species. Ninety-five percent confidence ellpses ọn group centrolds were plotted (Sokal and Rohlf 1969). The FORTRAN prograth used to calculate them is presented in Appendix IX. Loadings on the. DF's could have been used to Adentify the variables which contribute the. most to the group differentiation. However, when three, or more 
20

TABLE 2.2

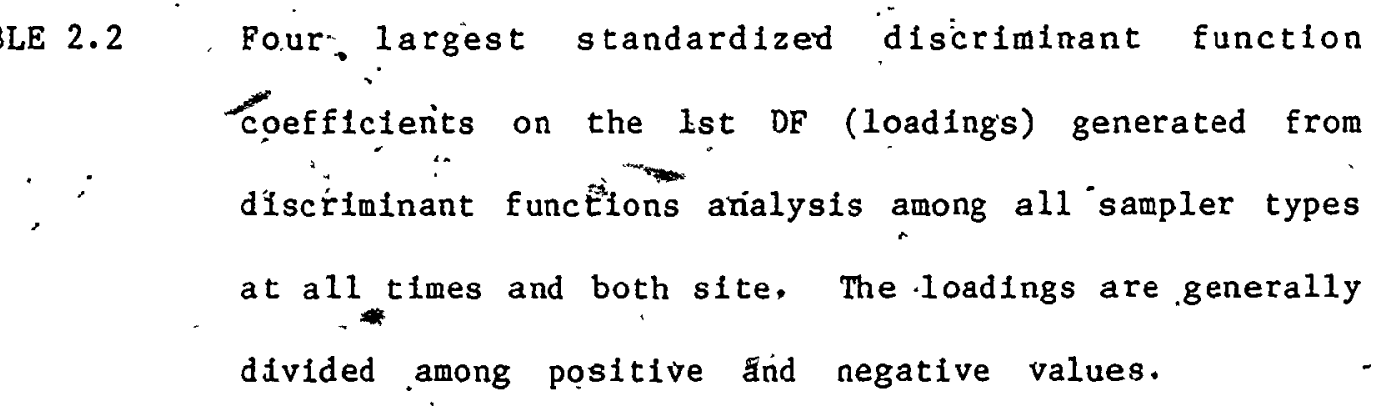



23

FIGURE 2.4 Repeated discriminant analyses on feeding data from Julysite A using 4 data types. The percentage of variation associated with each discriminant function (DF) is . presented. Eigenvalues, significance levels and

3 percentages of groups correctly classified are..presented. Only variables that pass the tolerance test were used.

Fish used were:

0

$\Delta \quad$ - winter flounder

$\Delta$ - ocean pout

- plaice

$\therefore$ 


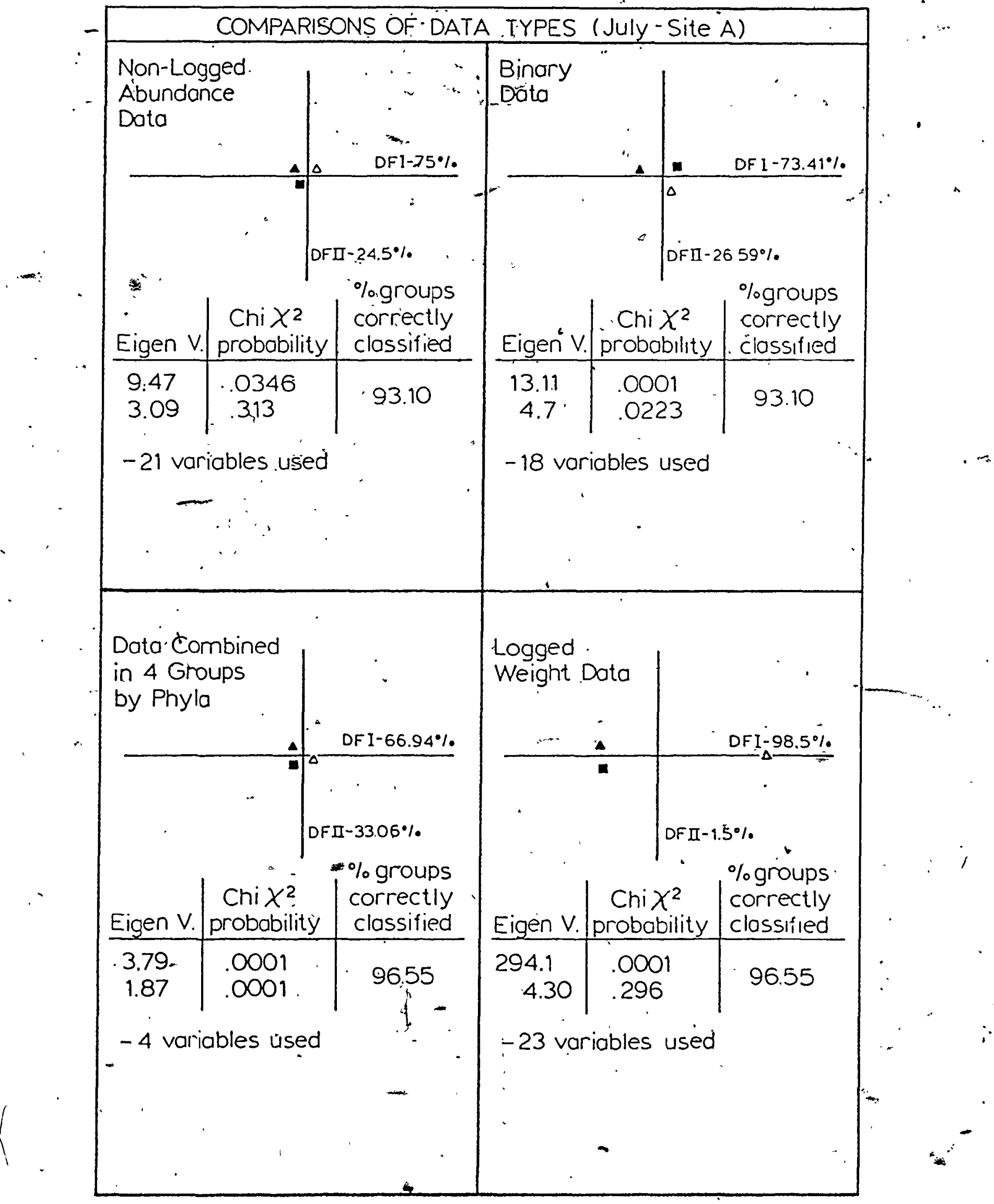




\section{RESULTS}

3.1 Fish Distribution - summary of the five year study

During the five year survey of fifteen sites in the lower Bay of Fundy region sixty-two fish. species in five groups were identified: an estuarlne group, a beach group, a deep hard bottom group, a deep soft bottom group and a pelagic group (Appendix I). Flatfish, gadolds; sculpins, clupëoids and rays dominated all groups, both. in species numbers and individuals. Species and/or age-class components. of each group varied seasonally, but * communities could be recognized at all times. Growth rates of winter flounder, cod, plaice, ocean pout and witch flounder did not differ between sites. There was a progressive seaward displacement of groups from shallow inshore habltats to deeper, offshore habitats in winter and a reverse movement in sumer. Changes in species occurrence and abundance recorded during the study period were mostly att́ributable to ocean climate variation. $\checkmark$ Changes in abundance since a similar study at site, A in 1965 reflect fluctuations in commercial stocks throughout the Maritimes. The beach zone was a major nursery area for juvenile gadoids, flatflshes and clupeolds. A more detalled account of the fish distribution work is presented in Appendix I.

3.2 Benthic Composition and Food Utilization - one year feeding study with the fishes described in Table 2.1.

3.2.1 Graphical Analysis.

Food utilized by the'fishes and benthic samples consisted of 217 infaunal and epifaunal invertebrate species. Very few fish species and no plants were consumed (Appendix VI). The.flshes, 
particularly cod and.plaice, did not utilize all the prey specles. that were sampled from the sediment.(Fig..3.1). Cod and plaice also consumed fewer prey tems (Fig. 3.2): The specles diversity and number of individuals in the sediment peaked at both sites $1 \hat{n}^{\prime}:$ late fali or early winter. However, as the water temperature declined in the 'fall, cod, ocean pout and winter flounder consumed decreasing - numbers of prey, spècies and individuals . " (Appendix I - Fig. 2). The plaice and witch fllounder dịd not show the same trend:- There was a greater species diversity and number of individuals in the sediment at site $A$ than at site $B$. However, there was no between-site difference in the number of items or species taken by each predator with the possible exception of the winter flounder consuming more 1 tems at site $A$.

Ninety-seven percent of the number of benthic invertebrates at - both sites were either annelids (35\%) mollusks (20\%) "or arthropods (42\%). Site A had large numbers of arthropods (45\%) and annelids (50\%) but few mollusks (5\%). Site B was annelid $(65 \%)$ and mollusk $(20 \%)$ rich with fewer arthropods (15\%). At both sites more worms were sampled from the sediment in the winter and early spring than during the warmer months (F1g. 3.3). Winter flounder fed on large numbers of annelids at site $B$ and large Humbers of arthropods at ste $A_{;}$Cod fed primarily on arthropods at both sites and times. Plaice-fed on large numbers of ánnelids and arthropods throughout. the year. They also took mollusks at most times of year. Alaice fed more heavily of arthropods at site A than site B. Ocean pout: sampled during the summer and fall held large numbers of mollusks: Those sampled in 



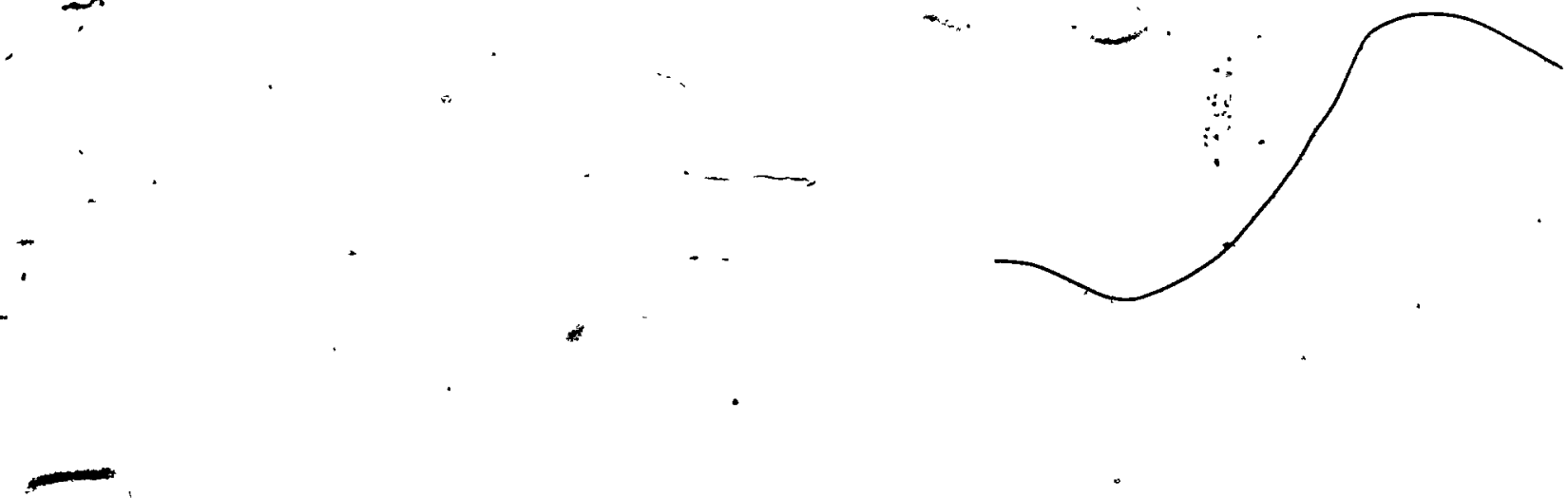

-FIGURE 3.2 Graph of mean number of items sampled from each sampler- type at each collection time. Vertical lines indicate 1 standard error of the mean. Site $B$ bars are shaded and site $A$ are clear. A dot without a bar indicates that 

31

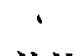

$\because \cdots$

FIGURE 3.3 Percent by number of individuals in Annelid, Arthropod and Mollusk phyla collected by each sampler-type at each site and time.

\section{SYMBOLS}

TIME SITE A

SITE B

\begin{tabular}{lcc} 
& $\frac{\text { SYMBOLS }}{i}$ & \\
TIME & SITE A & SITE B \\
\hline July & 1 & A \\
Aug. & 2 & B. \\
Oct. & 3 & C \\
Dec. & - & D \\
Jan. & 5 & E \\
Apr. & 6 & F \\
June & 7 & G \\
\hline
\end{tabular}

A

FIGURE 3.3

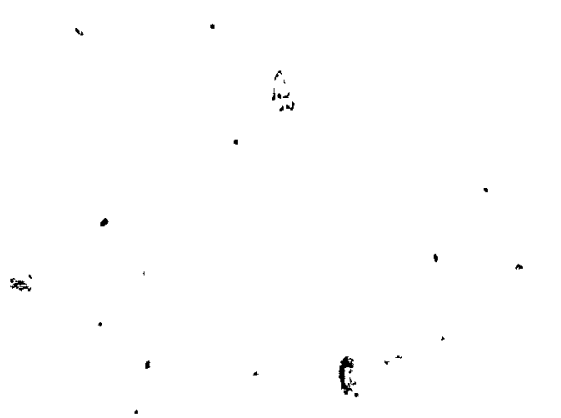


the spring contained larger numbers of arthropods (site A) or annelids (site B). Witch flounder fed on arthropods at all times of year (Fig. 3.3).

The following variables had lower densities in the winter at both sites: Thyasira flexuosa, Yoldia sapotilla, Nucula delphinodonta, Sternaspis scutata, Ninoe nigripes and many amphipod species. Leptocheirus 'pinguis, Syrrhoe crenulata, Praxillellà praetermissa, Nucula proxima, Arctica 1slandica, Nuculana 'tenuisulcata and Owenia fusiformis had lower densities in the winter at site A only. Cerastoderma pinnulatum had a lower density in the winter at site $B$ only (Appendix VIII). Many benthic species were commonly found at both sites (eg. Lumbrineris fragilis, Nephtys incisa, Scalibregma inflatum and $\underline{Y}$. sapotilla etc.). Others were particular to one of the two sites. Site A the annelid - arthropod community, had a dense assemblage of the annelids: $\underline{P}$ praetermissa, Harmothöe imbricata, Eteone trilineata, Amphipolis squamata, family Ampharetidae, Melinna cristata, the arthropods: ‥ pinguis, Diastylls quadrispinosa, three species of Unciola and the mollusks: $\underline{C}$. pinnulatum and $\underline{N}$. proxima. Site $B$, the annelid community, had a dense assemblage of the annelids: $\underline{S}$. scutata, Heteromastus fillformis, Rhodine loveni, Chaetozone setosa; the mollusks: N. tenulsulcata, N. delphinodonta, Periploma fragile; and the arthropod: Casco bigelowi.

The macrobenthos was divided into three groups according to thelr feeding methods (Table 3.1). Unt1l more autecological information is avallable a rough food classification scheme was 
34

Table of benthic species that" occurred in large numbers at both'sités (C), site B (B) or site A (A). An 'S', at sich marks species that show seasonal fluctuations in abundance; Where avaliable, feeding -methods (D deposit, SU - suspension and C - carnivore), spawning times, life spans (SH 1 - 2 yrs, L. $2+$ ỵ̦s.) and diel vertical migration patterns within the water column (+ migrates, - does not migrate) are indicated. 
TABLE 3.1

\begin{tabular}{|c|c|c|c|c|c|}
\hline Species & $\begin{array}{l}\text { Occur- } \\
\text { rence }\end{array}$ & $\begin{array}{l}\text { Feeding } \\
\text { Method }\end{array}$ & $\begin{array}{l}\text { Spawning } \\
\text { Times }\end{array}$ & $\begin{array}{l}\text { Life } \\
\text { Span }\end{array}$ & $\begin{array}{l}\text { Vertical } \\
\text { Migrations }\end{array}$ \\
\hline Praxiliella praetermissa & $S-A$ & $\mathrm{D}$ & & & - \\
\hline Harmothoe imbricata & A & C & Apri1 & $\mathrm{SH}$ & $\because \quad+$ \\
\hline$\overline{\text { Eteone trilineata }}$ & c & $D$ & & & \\
\hline Amphipholis squamata & C & su & & ' & - \\
\hline Ampharetidae & A & $\mathrm{D}$ & May. & Sil & - \\
\hline Melinna cristata & A & D & & & - \\
\hline Heteromastus f11iformis & B & D & Apr. -May & & - \\
\hline Rhodine loveni & B & D & & & - \\
\hline Chaetozone setosa & B & D & & & - \\
\hline$\overline{\text { Sternaspis }}$ scutata & $S-B$ & D & Sept. & & - \\
\hline Cerastoderina pinnulatum & $S-A$ & SU & & & - \\
\hline Nucula $\mathrm{sp}$. & . $\mathrm{s}$ & $\mathrm{D}$ & & & - \\
\hline Nuculana tenuisulcata & B & D & * & & - \\
\hline$\overline{\text { Astarte }} \mathrm{sp}$. & $A$ & SU & & L & - \\
\hline Periploma Eragile & B & su & 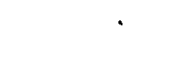 & & - \\
\hline Leptocheirus pinguis & $S-A$ & $\mathrm{SU}$ & $\begin{array}{l}\text { Jan. or } \\
\text { July }\end{array}$ & $\mathrm{SH}$ & \\
\hline Diastylis sp. & A & $\mathrm{D}$ & & $\mathrm{SH}$ & + \\
\hline Unciola sp. & A & D & & SH & \\
\hline Casco bigelowi & $S-B$ & D & July & SH & \\
\hline Arctica islandica & $s-c$ & SU & & & - \\
\hline $\overrightarrow{\text { Syrrhoe }} \overrightarrow{\text { crenulata }}$ & $s-c$ & $\mathrm{D}$ & & $\mathrm{SH}$ & ; \\
\hline Nephtys Incisa. & C & $\mathrm{D} / \mathrm{C}$ & May & $\mathrm{L}$ & \\
\hline Lumbrineris fragilis & c & $\mathrm{C}$ & July-Aug & & - \\
\hline Scalebragma inflatum & c & $\mathrm{D}$ & & & \\
\hline Yolidia sapotilla & $s-c$ & D & Winter & & - \\
\hline Harpina propinqua & C & $\mathrm{D}$ & & SH & \\
\hline Thyasira flexuosa & $s-c$ & SU & 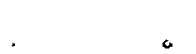 & & - \\
\hline Haploops fundlensis & $s-c$ & SU & & $\mathrm{SH}$ & \\
\hline Orchomonella minuta & $\mathrm{C}$ & D & & SH & \\
\hline Ninoe nigripes & $S-C$ & D & Sept. & & - \\
\hline Owenia fusiformis & $s-c$ & SU/D & & SII & - \\
\hline
\end{tabular}


all that was possible. The majority of the benthic invertebrate specles were omnivorous, feeding on bacteria, algae, other inicroorganisms and non-living detritus thạt accumulates in the sediment (Arntz 1975): Surface and subsurface deposit feeders feed on living and non-living micro-organisms on or within the sediment. Suspension feeders filter detritus and organic material suspended above the sediment surface. Carnivores are predators on other benthic invertebrates (Barnes 1968; Wildish and Linkletter pers. comm.). Many cumaceans and Harmothöe 1mbricata ascend at night and are therefore avallable to fish prédators.

Most benthic animals in Passamaquoddy Bay spawn in spring or mid-summer and their life span is úsually less than two years (Lacalli 1981). Leptocheirus pinguis sampled from the mud were smallest $(0.56-0.76 \mathrm{~cm})$ in summer $(P<0.05)$ and therefore probably spawned in late winter or early. spring (Fig. 3.4 ). Wildish (1980) reports this spectes to spawn twice, in January and August. Casco bigelowi spawns once, in July at both sites, with juventles appearing in the spring $(0.57-1.0 \mathrm{~cm})$. Casco bigelowi lives longer than most other amphipods (3-yr) (W1ldish). The presence of several age classes explains the variability in size at each collection time. Yoldia sapotilla are largest in. late summer or early fall $(0.68 \mathrm{~cm})$ and smallest in early spring $(0.17 \mathrm{~cm})$ at both sites. Spawning probably occurs over winter: Individuals at site $A$ are larger than those at site $B \quad(P<0.05$, Site by time 2 Factor ANOVA; Fig. 3.4).

Generally, the fishes' food resource habits were a function of 
37

- FIGURE 3.4 Mean $\{$ ire of 3 common. benthic species collected throughout the year at two sites (only $\underline{L}$. pinguid from site $A$ were measured). Vertical 1 ines are $95 \%$ confidence limits about each mean. 'Sample sizes' are: $\underline{\text { L. }}$ pinguid $\mathrm{n}=426, \underline{\mathrm{Y}} \cdot \underline{\text { sapotilla }} \mathrm{n}=359$ and $\underline{\mathrm{C}} \cdot \underline{\text { bigelowi }}$ $\mathrm{n}=218$.

$0=-\operatorname{site} A-1$.

O - site B 

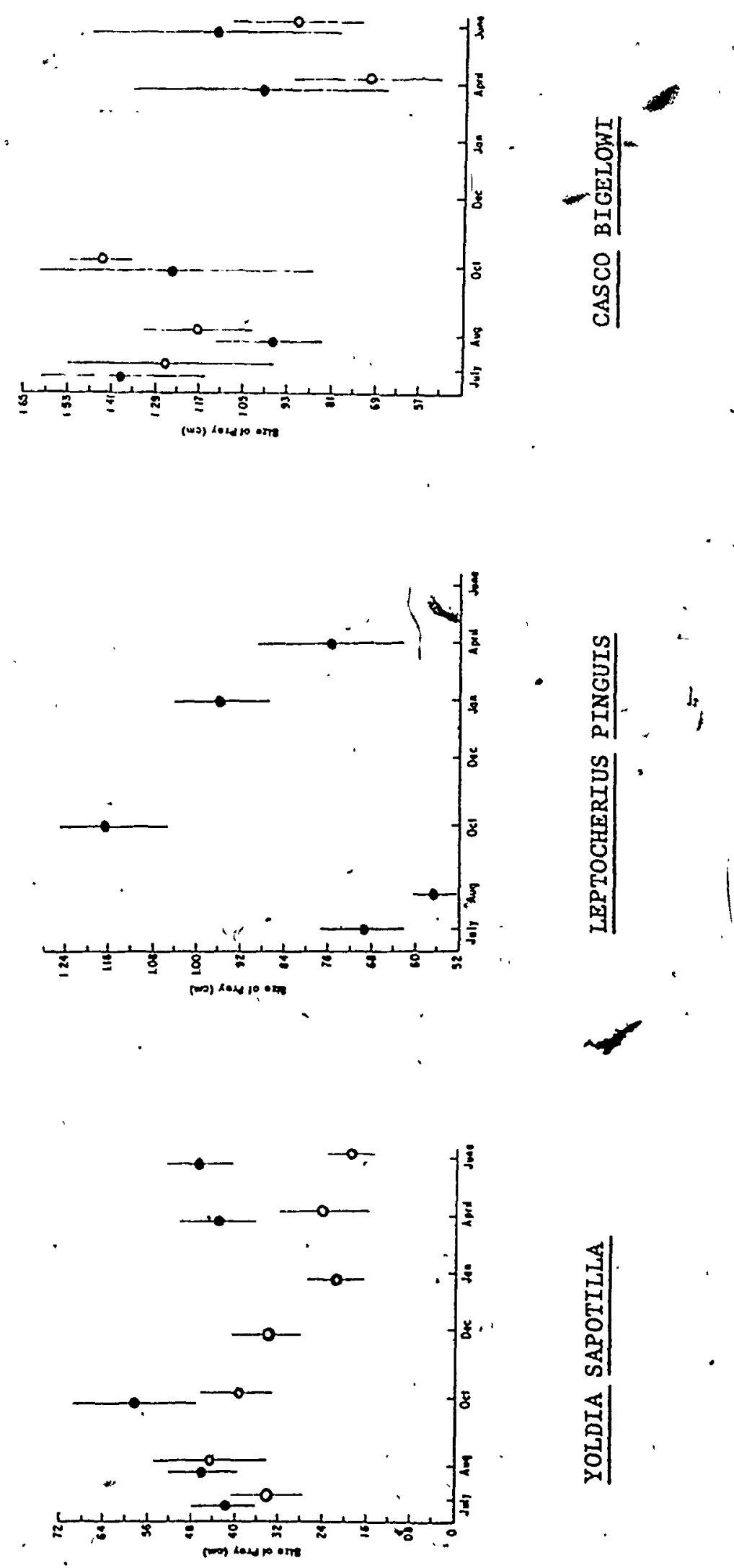

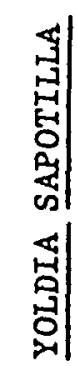


fish species and of spatial and temporal fluctuations in benthic prey species density. Examples and exceptions to this are introduced at this point using detalls from Appendix VIII. However, the fishes' reactions to benthos density changes is the major theme of the next section of the results (3.2.2 Statistical Analysis).

Praxillella praetermissa, $\underline{H}$. imbricata, E: trilineata, Ampharetidae, $\underline{\text { D. quadrispinosa, }} \underline{\text { L. pinguis, }} \underline{\text { C. bigelowi }}$ and $\underline{\mathrm{S}}$. scutata are all consumed in the largest quantities by winter flounder at those times and sites where they arẹ most abundant. However, despite large quantities at site B, mollusk consumption was restricted to $\underline{Y}$. sapotilla at site A.' More Yoldia were consumed in the summer and early fall than in spring.

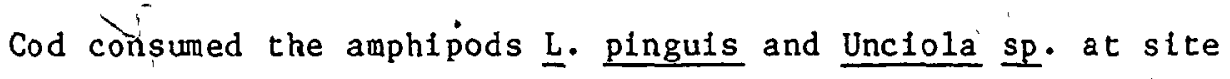
$A$, mysids rand the euphausiid Meganyctiphanes norvegica at site B. Unfortunately mysids and euphausids cannot be sampled accurately. with a benthic grab but both types of amphipods were more abundant at site A. Unciola spp., were consumed in the largest quantities when they were least abundant in the sediment, during spring. However, the smallest cod were caught in the spring and $\theta^{*}$ crustaceans are eaten more frequently by small cod than larger opes (Arntz 1974; 1978a). Annelids and mollusks were consumed in large numbers in the summer.

palce utilize N. incisa, S. scutata, L. pinguis, E. rubrocincta, $\underline{C}$. bigelowi, $\underline{A}$. squamata and Ampharetidae in relative quantities that reflect benthic abundance at most times and sites. There 1s, however, an exception to this. At site B 
in July, plaice reduced their intake of $\underline{Y}$. sapotilla and $\underline{S}$. scutata to consune $\underline{C}$. bigelowi. At approximately the same time, at both sites, ocean pout switched from arthropods (Unciola spp.,

$\because$ c. bigelowi, $\underline{\text { L }} \cdot$ pinguis) to mollusks and annelids (s. 'scutata, c. alba, $\underline{\text { Y. }}$ sapotilla, , Nucula spp.). Neither of the shifts coincided with changes of benthic prey density in the sediments.

Witch flounder consumed $\underline{\mathrm{s}}$ : scutata, ㄴ. fragilis, N. nigripes,

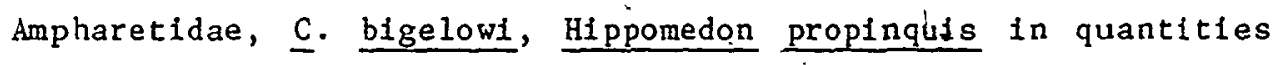
that reflect benthic abundance. Yoldia sapotilia is the only mollusk consumed in large numbers and is taken more often, in the summer while arthropods are favoured in the spring.

\subsection{2 . Statistical Analysis}

Significant three way interaction occurred among sites, times and all sampler-types ( $P<0.01$, MANOVA). Before the analysis could be performed, the data from December and the data from witch flounder were removed to give a fully crossed design. Bartlett's test for homogenelty of variances was significant due, partially, to skewness of the data $(P<0.05)$. Partioning the matrix into all posstble two-way designs and one-way ádesigns at each site-time combination showed there to always be significant data structure to be explored in this study $(K 0.01)$. With the aid of three dimensional stereograms (Fewster and orloci 1978) and discriminant analysis, spatial and temporal "fluctuations in benthic composition were displayed (Figs. 3.5 and 3.6). Species compositions in the mud at sites $A$ and $B$ are significantiy different (DFI, $P<0.01$ ). Both sites show temporal variation although composition of spectes in the mud at site $A$, 
41

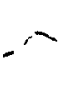

1

$+-$

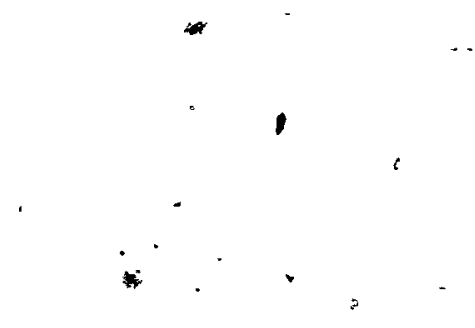

$?$

FIGURE 3.5. A three dimensiónal stergogram, when viewed with a stereoscope, shows separation in five distinct clusters. one cluster coifresponds to discriminant scores for all collection times at site B. The other four show the.$- "$ separation that occurs among the temporal groups at site A. A reference map to Identify the groups is presented in Fig. 3.6 .

$\theta$ 

43

- FIGURE $3.6^{\prime \prime}$ Reference map to identify the cluster's from the

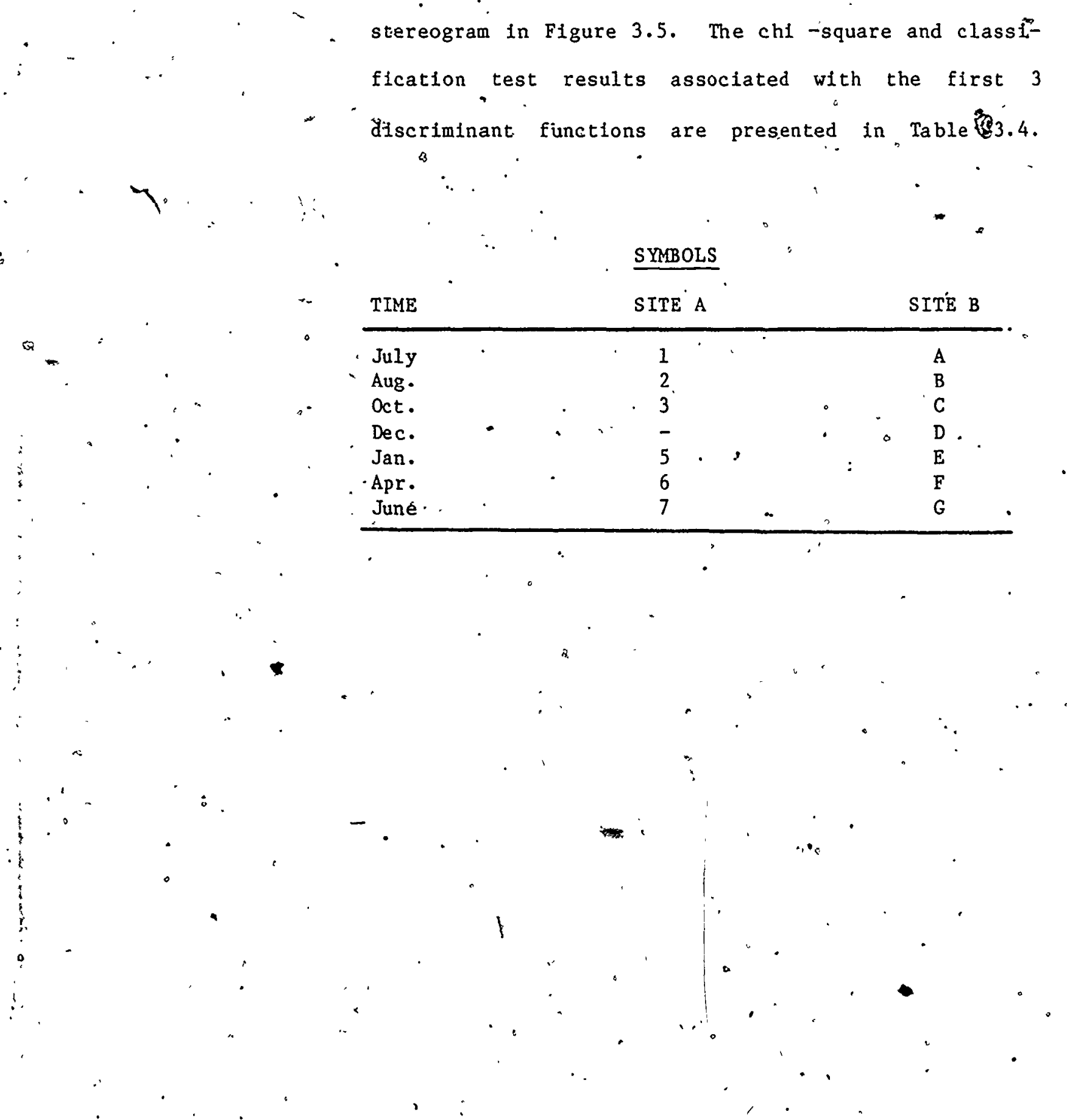




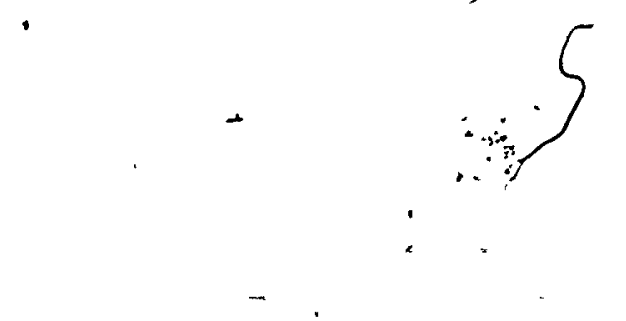

44

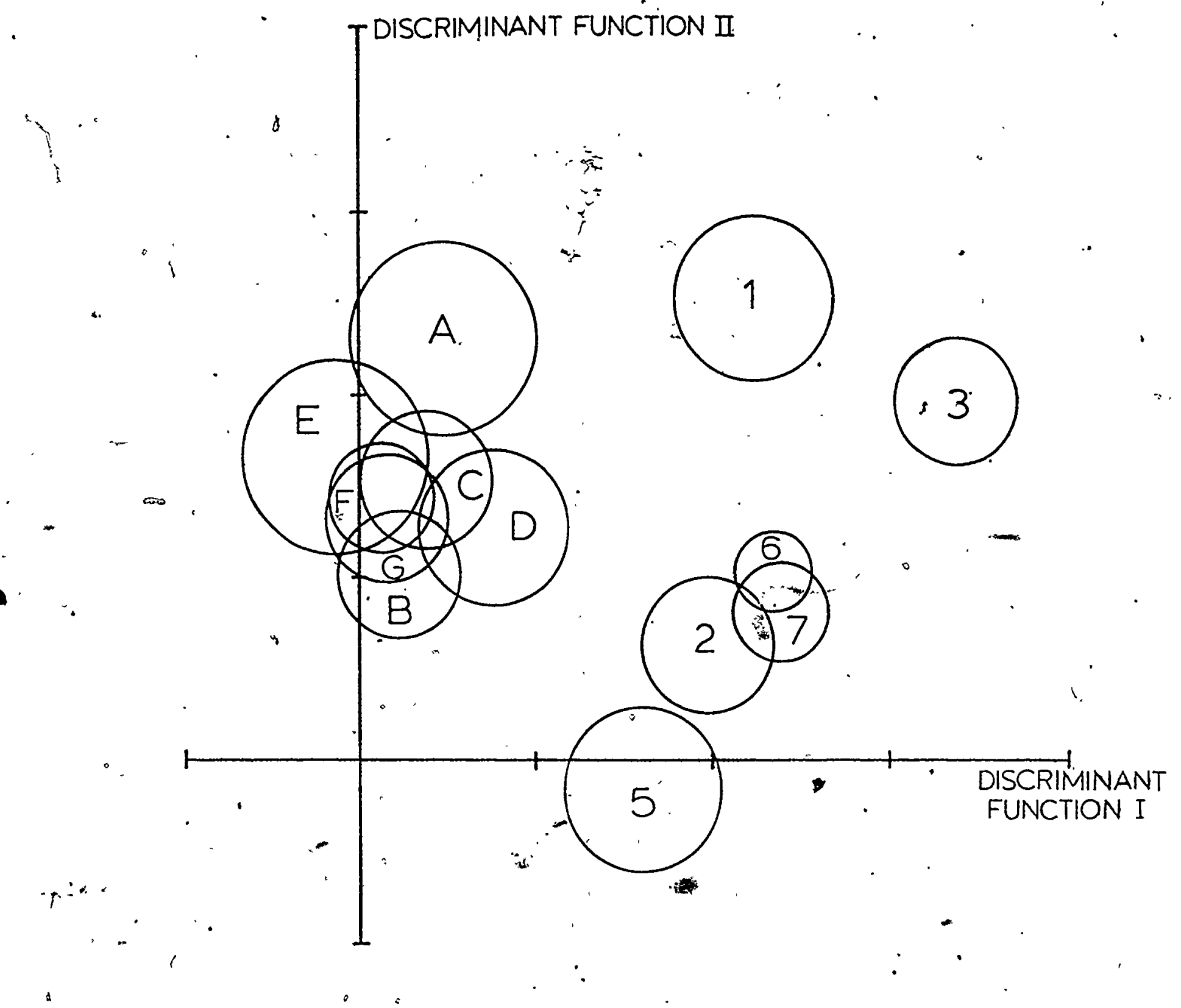




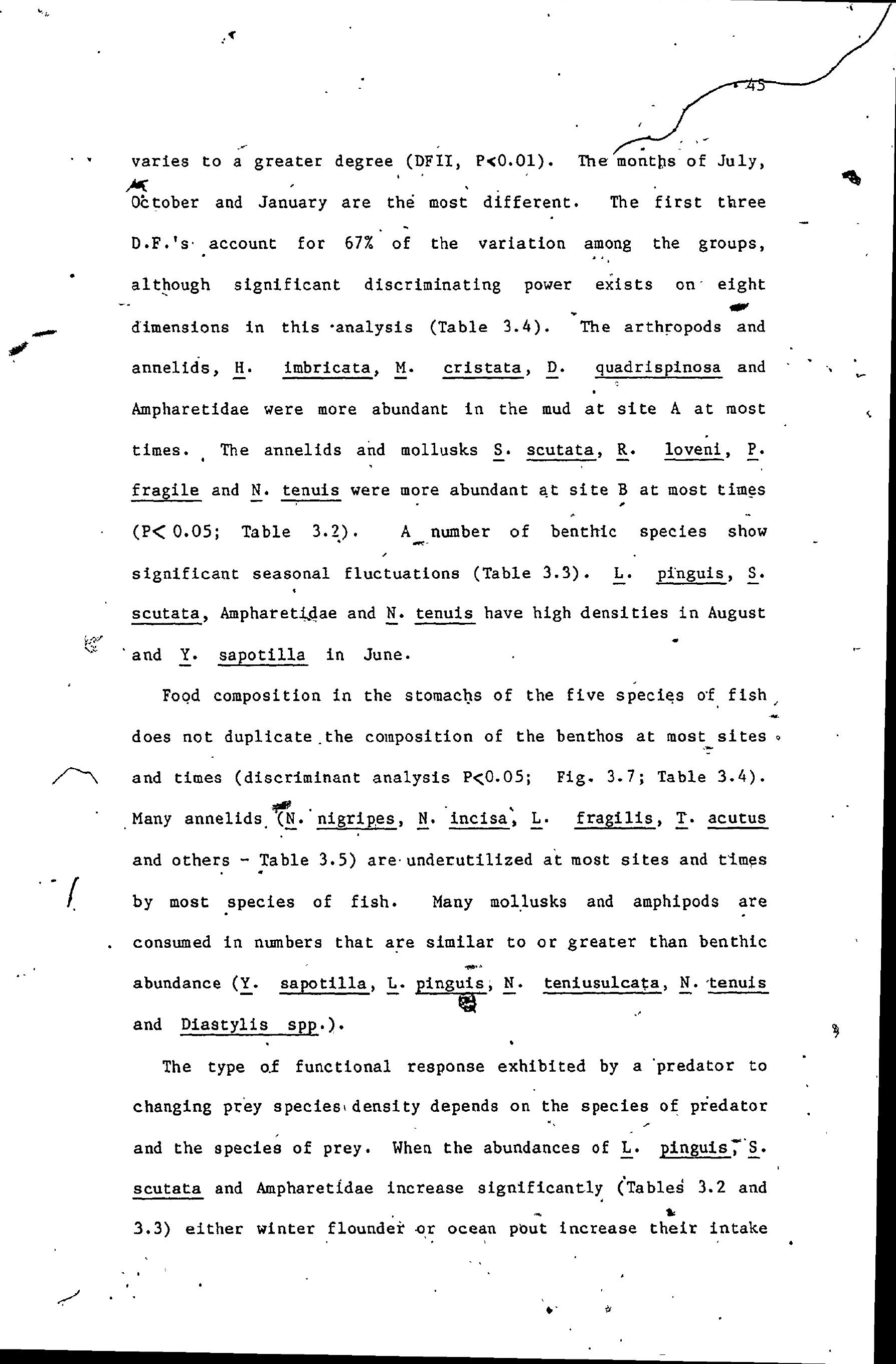


L

46

*.

TABLE 3.2

Ranked log abundance variables that discriminate between sites using the F-statistic (Jancey 1979). Variables are significant at the 0.05 level after Bonfernoni's inequality equation was applied. 'Letters 'indicate site at which each variable was most abundant during each collection period. 


$$
\because=
$$

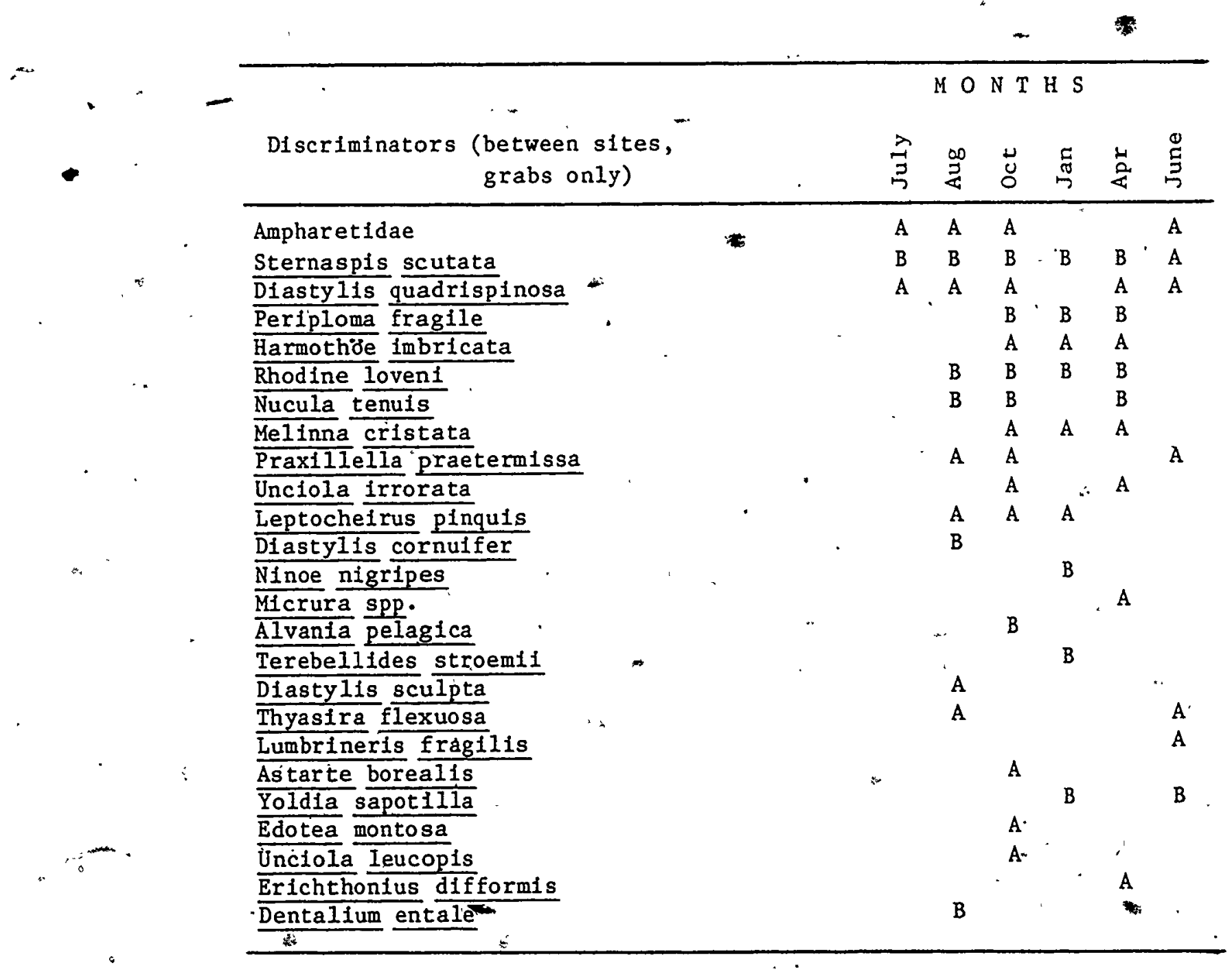


Variables are ranked by their abllity to discriminate betweèn all pairwise comparisons-of successive collection times at each site using the F-statistic (Jancey 1979). Variables are significant at the 0.05 level, after Bonferroni's fnequality equation was applied. Letters in. brackets indsate the month at which each variable was. most abundant. Variables were logged to reduce skewness.

s.

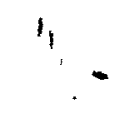




\begin{tabular}{|c|c|c|c|c|}
\hline TIME & \multicolumn{2}{|c|}{ SITE A - DISCRIMINATORS } & \multicolumn{2}{|l|}{ SITE B - DISCRIMINATORS } \\
\hline July-Augg & $\begin{array}{l}\text { Diastylis quadrispinosa } \\
\text { Ampharetidae } \\
\text { Praxillella praetermissa } \\
\text { Periploma fragile } \\
\frac{\text { Diastylis }}{\text { Lumbrineris }} \frac{\text { sculpta }}{\text { fragllis }} \\
\frac{\text { Leptochelrus }}{\text { Harmothóe imbricata }}\end{array}$ & $\begin{array}{l}(\mathrm{J}) \\
(\mathrm{J}) \\
(\mathrm{A}) \\
(\mathrm{J}) \\
(\mathrm{A}) \\
(\mathrm{A}) \\
(\mathrm{A}) \\
(\mathrm{A})\end{array}$ & 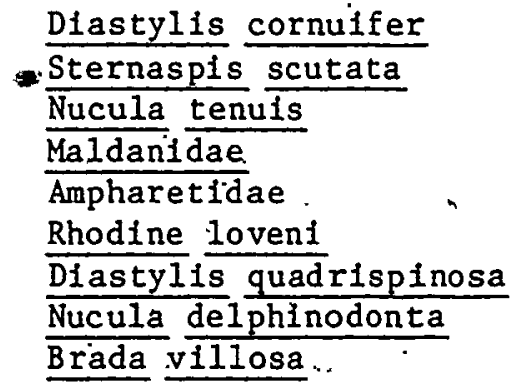 & $\begin{array}{l}\text { (A) } \\
\text { (A) } \\
\text { (A) } \\
\text { (A) } \\
\text { (A) } \\
\text { (A) } \\
\text { (A) } \\
\text { (A) }\end{array}$ \\
\hline Aug $-0 c t$ & $\frac{\text { Edotea montosa }}{\text { Phyllodoce groenlandica }}$ & $\begin{array}{l}(0) \\
(0)\end{array}$ & $\frac{\text { Alvania }}{\text { Diastylis colagica }}$ & $\begin{array}{l}\text { (0) } \\
\text { (A) }\end{array}$ \\
\hline Oct-Dec & -- & - & $\frac{\text { Chaetozone sétosa }}{\text { C. pinnulatum }}$ & $\begin{array}{l}\text { (D) } \\
\text { (0) }\end{array}$ \\
\hline $\begin{array}{l}\text { Oct-Dec } \\
\text {-Jan }\end{array}$ & $\begin{array}{l}\text { Diastylis quadrispinosa } \\
\text { Astarte borealis }\end{array}$ & $\begin{array}{l}(0) \\
(0)\end{array}$ & $\frac{\text { Chaetozone setosa }}{\text { Nephtys incisa }}$ & $\begin{array}{l}\text { (D) } \\
\text { (D) }\end{array}$ \\
\hline Jan-Apr & Ninoe nigripes & (A & Terebellides stroemi1 & $(\mathrm{J})$ \\
\hline Apr-June & $\frac{\frac{\text { Uneiola }}{\text { Yoldia }} \frac{\text { irorata }}{\text { sapotilla }}}{\text { Lumbrineris fragilis }}$ & $\begin{array}{l}\text { (A) } \\
\text { (J) } \\
\text { (J) }\end{array}$ & $\therefore$ & $\cdot$ \\
\hline 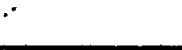 & - & & & \\
\hline
\end{tabular}




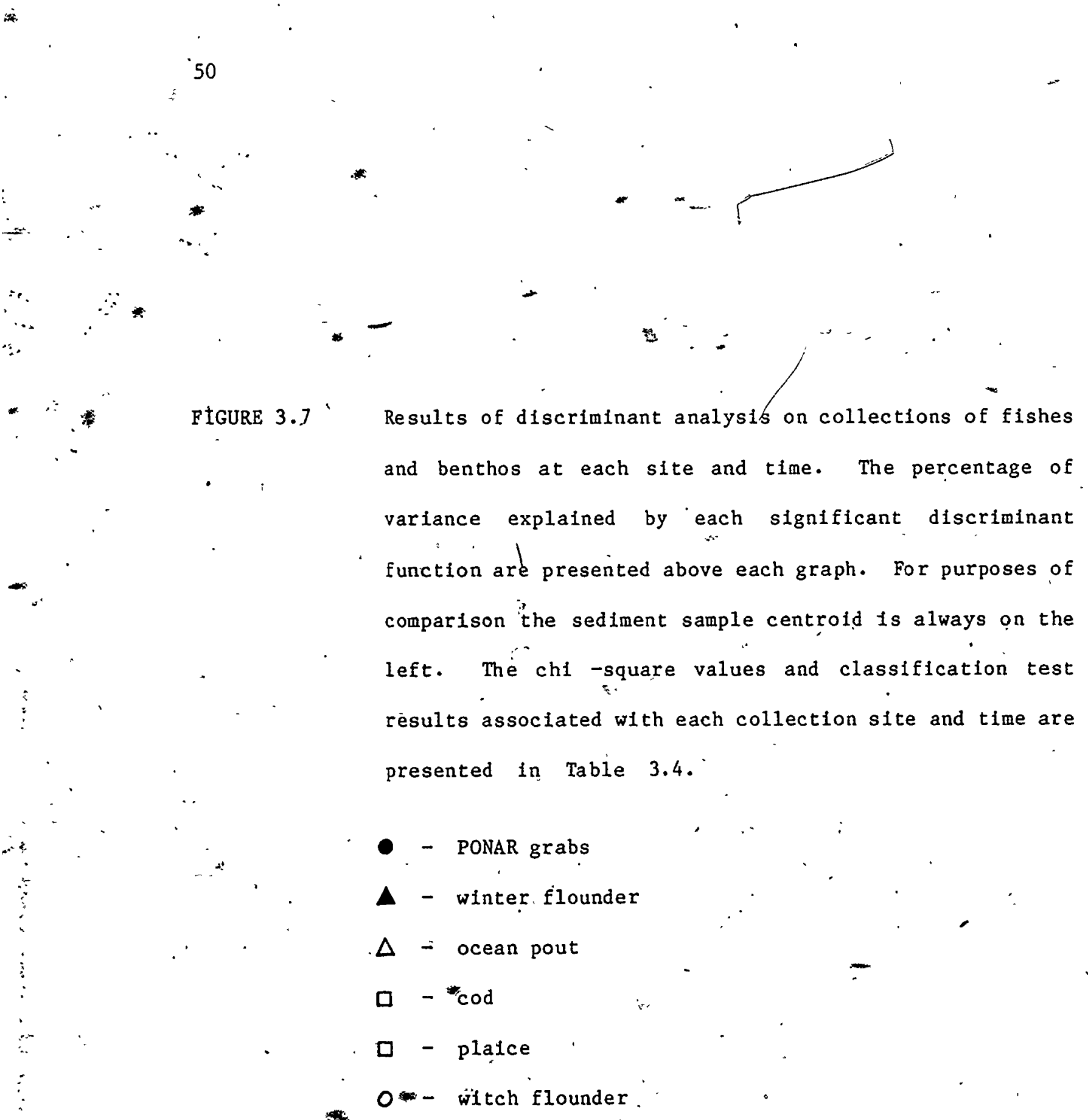




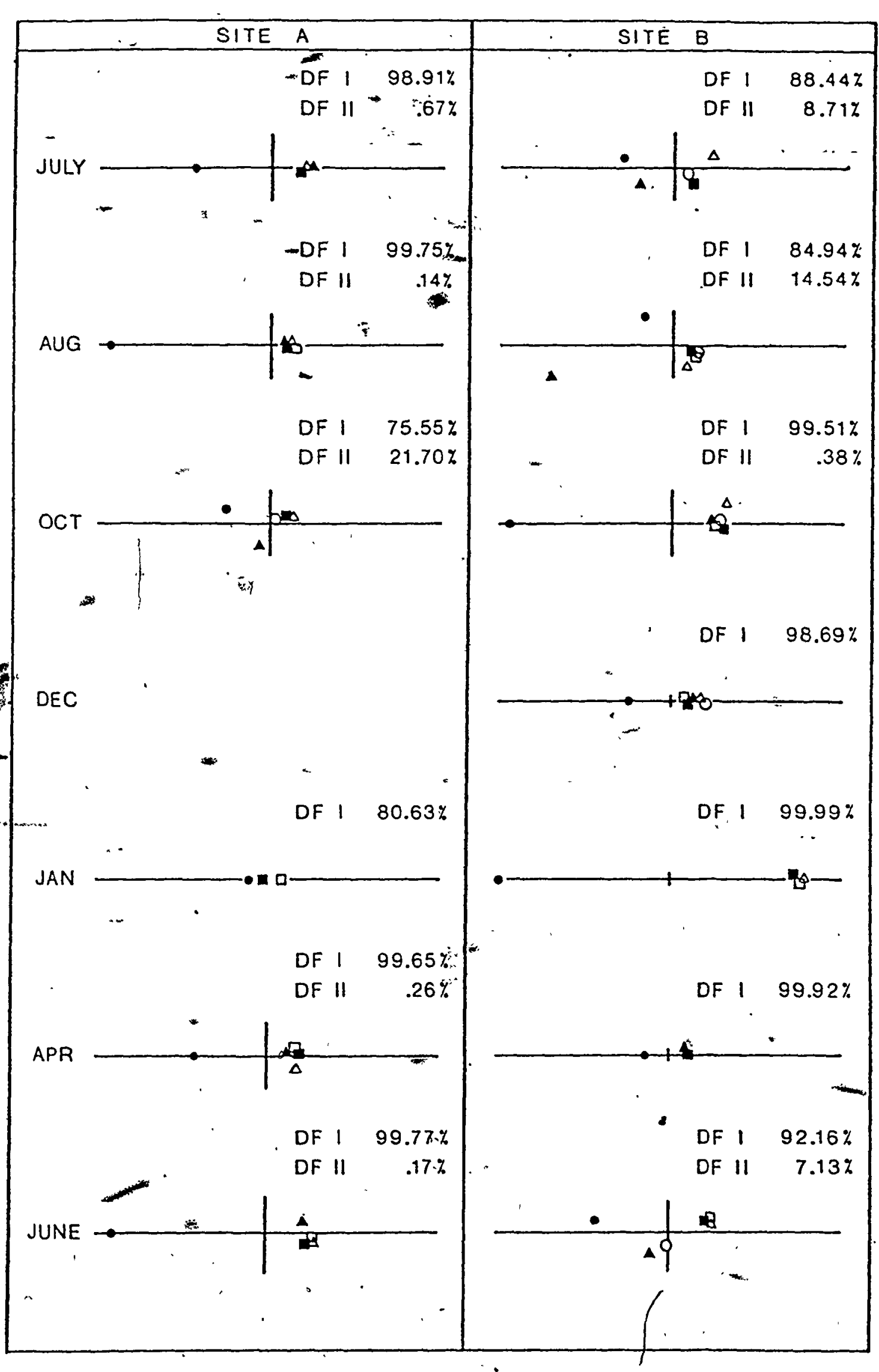


TABLE 3.4 Eigenvalues (variances), cumulative percent variation, chi -square test significance levels and results of the SPSS classification test results for the discriminant analyses performed on benthic:-and fish species groups' collected at each site-time combination.

\section{,} $\ldots$

$\cdots$

.

$\because$
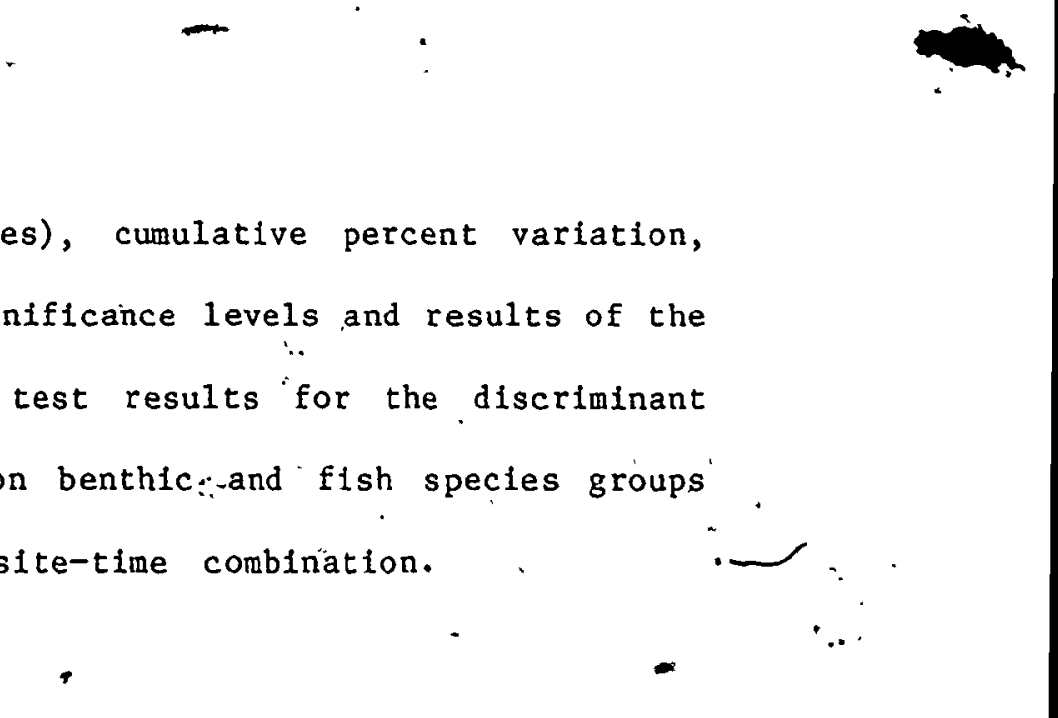

- 
DISCRIMINANT ANALYSIS RESULTS

PONAR GRABS AND ALL FISH SPECIES -

DISCRIMINANT FUNCTIONS

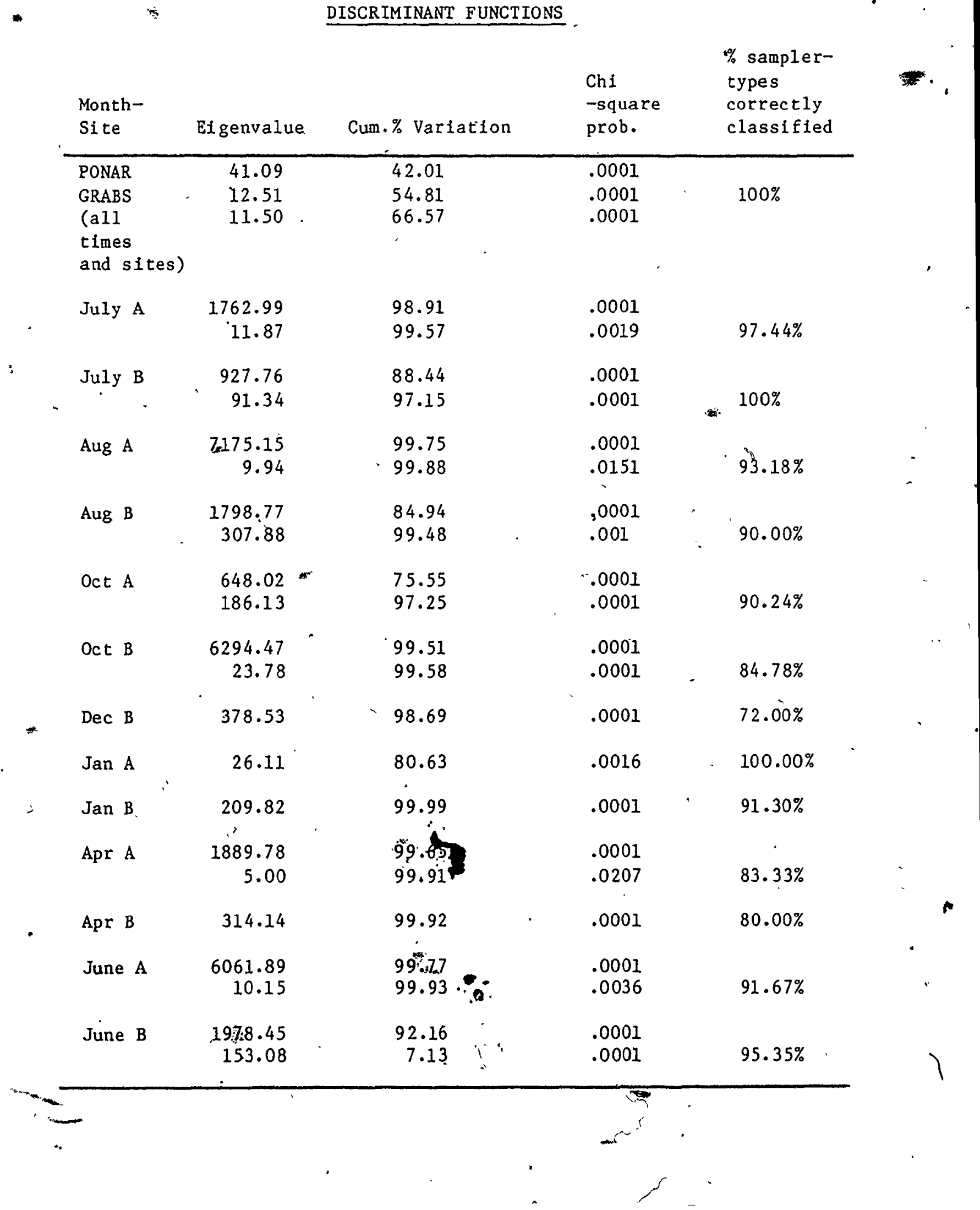


TABLE 3.5 Prey species ranked by F-values on their overa11 ability to significantly discriminate among sampler types $(P<0.05$ after Bonferron's inequality equation was used to obtain an overall confidence probability from a series of tests - Snedecor and Cochran 1980). Numbers assign rạks to each species at that particular site and time. Horizontal bars joln sampler-types with similar numbers of prey. Sampler-types are labelled, G-grab sample, F-" winter flounder, 0-ocean pout, P-plaice, C-cod and $W-$ witch flounder. Numbers of each prey in each samplertype decrease from left $(+)$ to right $(r)$. Variables that do not appear in this table show no significant abundance differences among sampler-types. 
SITE A

SITE B

Discriminators $\odot \oplus \Theta$ Discriminators $\oplus \oplus$.

Ninoe nigripes

Nephtys incisa

Sternaps is scutata

L. fragilis

Yoldia sapotilla
S Tharynx cacutus
Ampharetidae

D. quadrispinosa

P. praetermissa

L. pinguis

Maldanidae
1. $G \mathrm{FOCP}$

2 G F O C P

4 G FCOP.

$5 \longdiv { O G F P }$

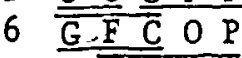

$\because \frac{\mathrm{G} \overline{\mathrm{F}} \mathrm{C} \mathrm{P}}{\mathrm{G}}$

$8 \longdiv { G O C F P }$

$10 \widehat{G C O P}$

$3 \longdiv { G O G P }$

$9 \frac{\mathrm{G} \overline{\mathrm{P} C F O}}{\mathrm{P}}$
Ninoe nigripes

Nephtys incisa

Sternaps is scutata

Yoldia sapotilla.

Rhodine loveni

Peripluma fraigile

Thyasira flexuosa

$N$. Eenuisulcata

Nucula tenuis
$1 \mathrm{GWF} C \mathrm{C} O \mathrm{P}$

6 GEPCQW

3. GEWOCP

2 OGWECP

4 GECOPW

5 GECOP W

8 GCFWPQ

. 7. OGCFPH

$9.0 G E C P$
Ninoe nigripes

Nephtys incisa

L. fragilis

Yoldia sapotilla

芘

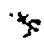

Tharynx acutus ......

Ampharetidae

D. quadrispinosa

P. praetermissa

L. pinguis

Thyasira flexuosa

Diastylis sculpta

$\$$
8 G F C P

1 G $\overline{P O C}$

3 G F $P$ O C

7 Q GPC

9- $C$ P F O

$6 \longdiv { \mathrm { G } \overline { \mathrm { FPO } } }$

4 GOF C

$2 \mathrm{G}$ FPOC

10 FGC P

$5 \frac{G C \bar{O}^{-P}}{G C C}$

11 GCP
Ninoe nigripes

Nephtys incisa.

L. fragilis

Tharyix acutus

Ampharetidae

Iี 0 . quadrispinosa

P. praetermissa

L. pinguis."

Melinna cristata

H. imbri:ata

Unicola irrorata

Astarte borealis

Eteone trilineata

$H$. fundiens is
$12{ }^{-G}$ F P O Ninoe nigripes

$13 \bar{G} \bar{F} \because$ Nephtys incisa

7. $\underline{G E P}$

$5 \quad \underline{G} E \mathrm{P} O$

2-, $\mathrm{G} F \mathrm{P} O$

$4 \quad G O P F$

6 GEPO

14

3

1

10

8

9

11
GF $O P$

$G \overline{E Q P}$

$\underline{G} \underline{O F P}$

$\mathrm{G} F \mathrm{PO}$

$G$ EPO

- $\underline{G P O}$

G F P O
L. fragilis

Rhodine loveni

D. cornuifer

Nucula tenuis

w. brevicalcar
Ninoe nigripes

Nephtys incisa

Sternaps is scutata

Yoldia sapotilla

Rhodine loveni

D. cornuijer

C. pinnulatum

Nucula tenuis

Qvenia fusiformis

Brada villosa

A. has ata

N. delphinodonta

Sternaps is scutata

Yoldia sápotilla

Periploma fragile

N. tenuisulcata

C. pinnulatum".

Alvania pelagica.

\begin{tabular}{|c|c|}
\hline 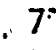 & $\mathrm{GEOC}$ \\
\hline 10 & $\mathrm{G} F \mathrm{OCW}$ \\
\hline 1 & $G Q E W C P$ \\
\hline 3 & $G 0 W F C P$ \\
\hline 5 & $G E \subset W P Q$ \\
\hline 2 & Go F N C P \\
\hline 8 & $Q G C E W P$ \\
\hline 6 & $\mathrm{GECQP \textrm {W }}$ \\
\hline 11 & GPQCEH \\
\hline 4 & $\mathrm{GPWCQVE}$ \\
\hline 9 & $0, C F W P$ \\
\hline 12 & $\mathrm{GEOCWP}$ \\
\hline
\end{tabular}

10

11

Q P W C

3 GWQEP C

12 GEWOC P

$40 G W P F C$

2 G CWPOF

8 G O F C P W

50 OGWCP

6 OGFP

7 OGEPW

9 GQFCP.W

1 QCEWCP

13 G FOW C P 


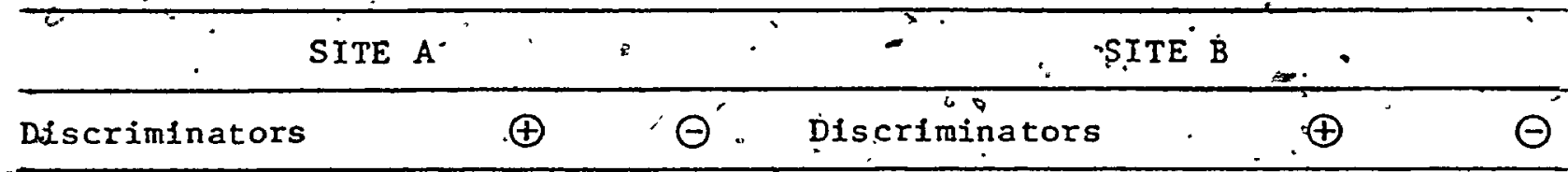

畏

$:=\quad+1$

L.'fragilis

Tharynx acutus Ampharetidae

$z$ L. pinguts

Melinna cristata

E. rubrocincta

H. imbriciata
Ninoe nigripes

Nephtys incisa

Sternapsis scutata

L. fragilis

Yoldia sapatilla

Tharinx acutus

N.. tenuisulcata

chaétozone setosa
.8 G C W O F P

1 G ${ }^{2} \mathrm{CO} P$

$2 \mathrm{G} W O F P$

$4 \overline{G ~ W O F ~ P ~}$

$3 \widehat{G ~} \bar{W} C O F P$

7 G C W O F P

6-. G CWOP

$5 \longdiv { \mathrm { W } C } \bigcirc \mathrm { FP }$
Ninoe nigripes

1. Fräilis

- Tharynx decutus

- Anipháretidae

D. quadrispinosa

$P$ : practermissa

Melinna cristata

H. imbricata
8 G C O F P? Ninot rigripes

1 G $\overline{F P C}$. Nephtis incisa

- 2 G O.P P C

$-5 \quad \bar{G} \bar{C} \quad 0 \quad F \quad P$

$4 \frac{G \overline{C O}}{\mathrm{G} P}$

$7 \overline{\mathrm{G}} \overline{\mathrm{C}} \overline{\mathrm{F}}$

$6 \longdiv { \mathrm { GCO } F \mathrm { P } }$

$3 \longdiv { G C F P }$

Sternapsis scutata

Yoldia sapotillia

Tharenx acutus

Periploma fragile

Thyasira flexuosa.

Vucula tenuis.

Micrura sp. '

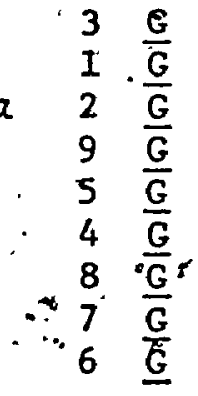

Ninoe nigripes

Nephtys incisa

siteirapsis scutata

L. fragilis

Yoldia sapotilla

Tharynx acutus

Ampharetidae

N. quadrispinos a

5. P. praétirnissa.

L. pénguis.

- Thyasira frexuosa Melinna cristata

N. teriuisutcata

Curenia busibormis 14 G O P C F

2. G F C P

$6 \quad \bar{G}$ F O C

is $\mathrm{G}$ OF P C

- I G F O.P

7: $\overrightarrow{G_{m}} \cdot \overrightarrow{0} \cdot \overrightarrow{F C}$

3. GEOP

$4 \mathrm{G} F O \mathrm{OC}$

10. G F O P C

9 G F OP.C

$: 12$ O.CFG

5 G O.F C.P

15 G. FC P O

$14 \overline{G P C F}$

$11 \cdot \overline{\mathrm{G} C \cdot O \mathrm{P}}$

$13 \overline{\mathrm{C}} \mathrm{FOP}$

16
- Unicola irrorata

Núcula proxima
Ninoe nigripes.

Nephtys incisa

- Sternaps is scutata

Tharynx acutus"

Periploma fragjile

- Qvenia fus iformis

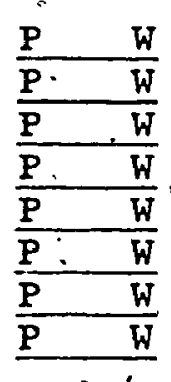

Ninoe nigripes.

Sternapsis scutata

$1 \mathrm{G}$

$4 \quad \frac{G}{G}$

$3 \frac{G}{G}$

8 .

. 6

5

क

2 。高. 
to consume significantly more than' ${ }^{\circ}$ the other fish and occastonaliy more than the number, sampled by the grab (Table 3.5). Ocean pout tend" to consume a constant proporition of mollusks ( $\underline{Y}$ sapotilia,$\underline{N}$ tenius) and other hard-body prey regardless of density unless an upper limit is set by sätiation (eg. D... quadríspinosa; Fig.3.8). Winter and witch flounder show a lagg response at:ílow densities of many prey spectés, and a rapid -increase, in consumption rate at higher densities. Exceptions to this may be $\underline{D}$. quadrispinosa, where there are" no data at intermediate prey densities, and L. fragilis.' Other predators respönd müch less dramătically to increasing prey density. Functional' response by 'cor may' be independent. -of prey density. However, some of the common prey spectes of cod could not be

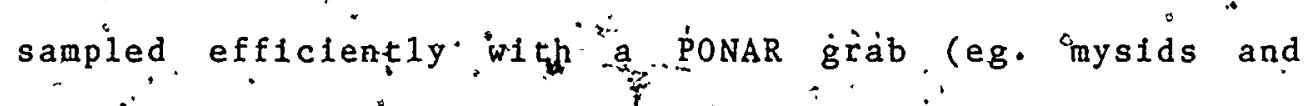
euphausilds) and therefore "abundance neasures "of avalfability" "could not be made'.

After ${ }^{\circ}$ repeating the series of discriminant analyses without the benthic grab samples 1 was clear that there was a great deal of foodresource partitioning among the pedators ( $P<0.05$; Fig. 3.9; Table 3.6). The prey spectes that show a significant difference in degree of utilization" among sampler-types are " 1isted in Table $3.5 !$ The results agree quite 'closely with the findings from'Appendix VIII: In fact, Table 3.5 appolles significant levels to the results already presented from Appendix VI.II.

The smallest amountrof of resource partitioning occurred during the collectlons when feedding rates were low (FIg; $u^{3.2}$ - December, 
58

FIGURE 3.8 Mean number of eight common species of prey consumed at different prey densities by the five predator species. Only prey that show significant changes in density among

- the sites and times sampled are exhibited (Table 3.2,

. 3.3). Data is not recorded for months when fishes were not' feeding (Fig. 3.2) or for fishes feeding on prey not common to their diet. Lines are fitted through the points by eye.

$\Delta$ - winter flounder (F)

$\Delta$ - ocean-pout

$(.0)$

a $-\operatorname{cod}$

(C)

- plates

(P):

. O - witch flounder (W) 


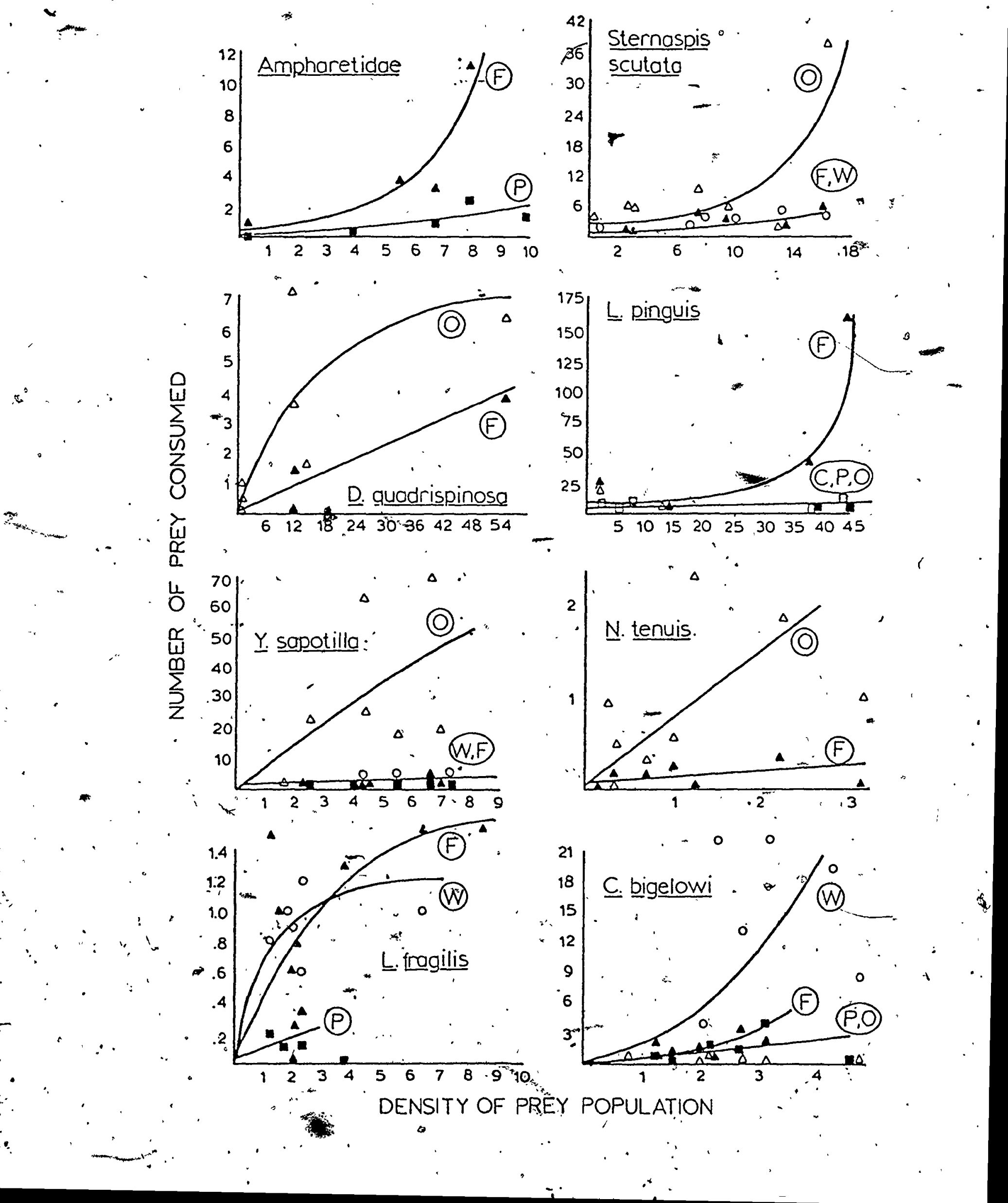


60

FIGURE 3.9

Results of discriminant analysis, on fish stomach collections at each site and time. The percentage of variance explained by each significant discriminant function is presented above each axis: Each centroid is surrounded by a $95 \%$ confidence ellipse. Asterisks refer to fish species where. the variance was too low to. calculate ellipses. Low variance may be caused by low sample number or empty stomachs. A discriminant score scale is presented in the lower left hand cornex-of the figure.

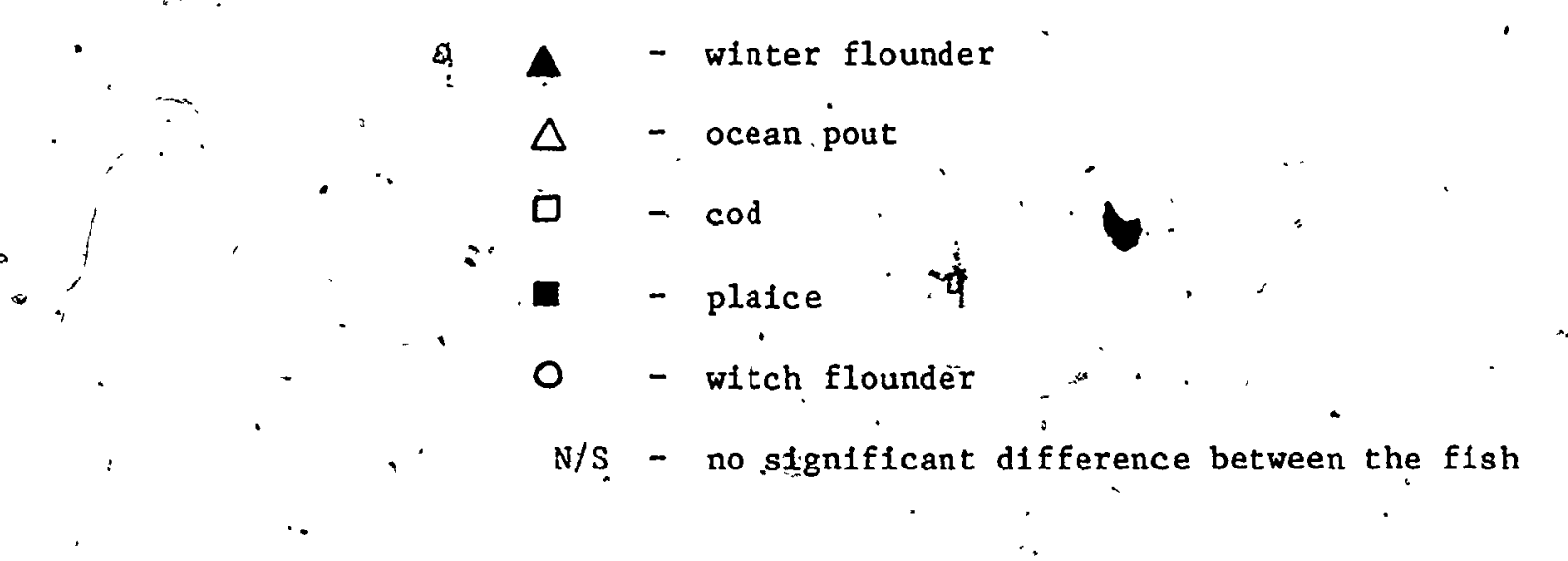


61

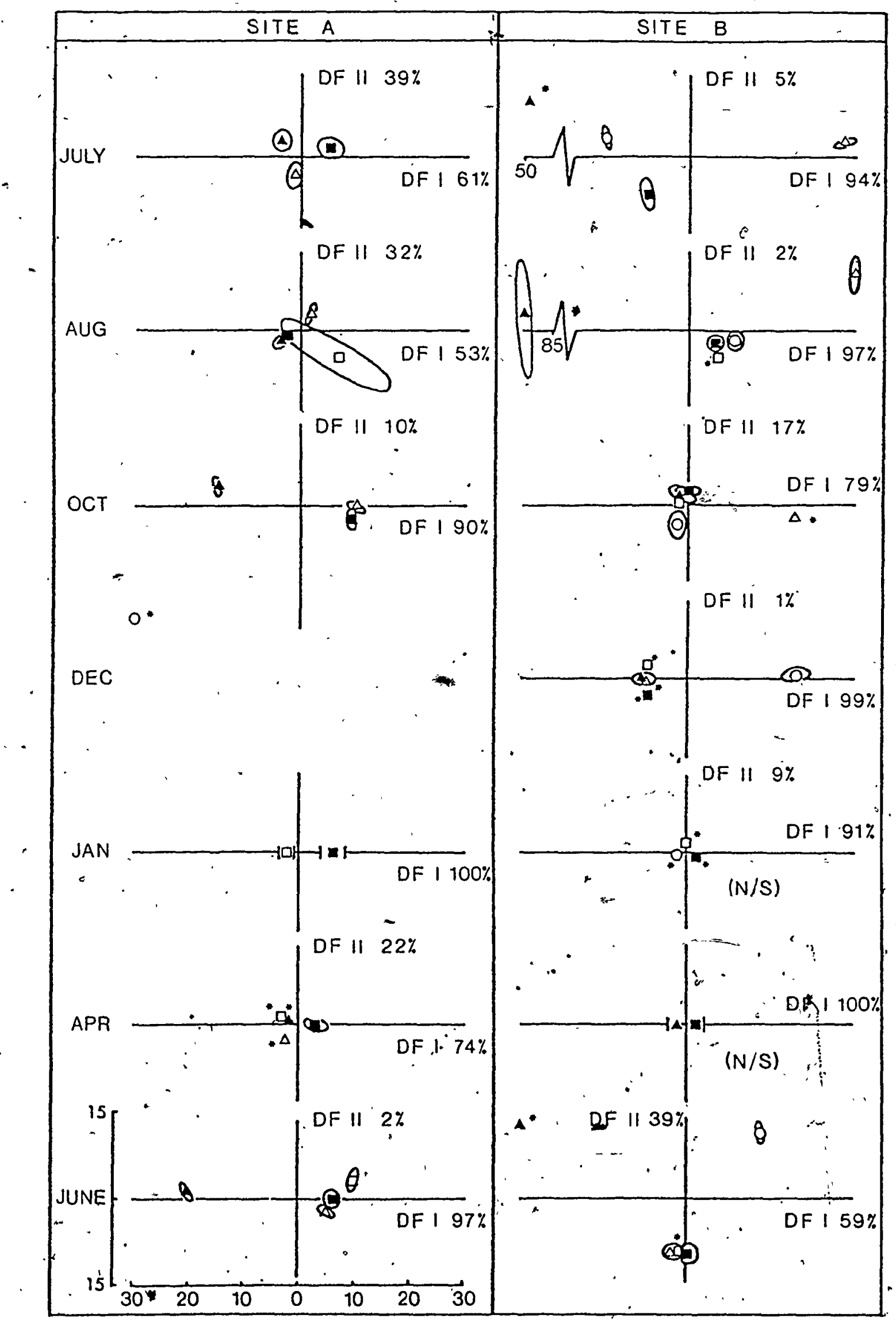



Chi -square test significance levels and results of the classification test results for the discriminant analyse's performed on fish species groups collected at each siteElme combination. Benthlc samples have been removed.

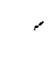

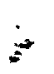
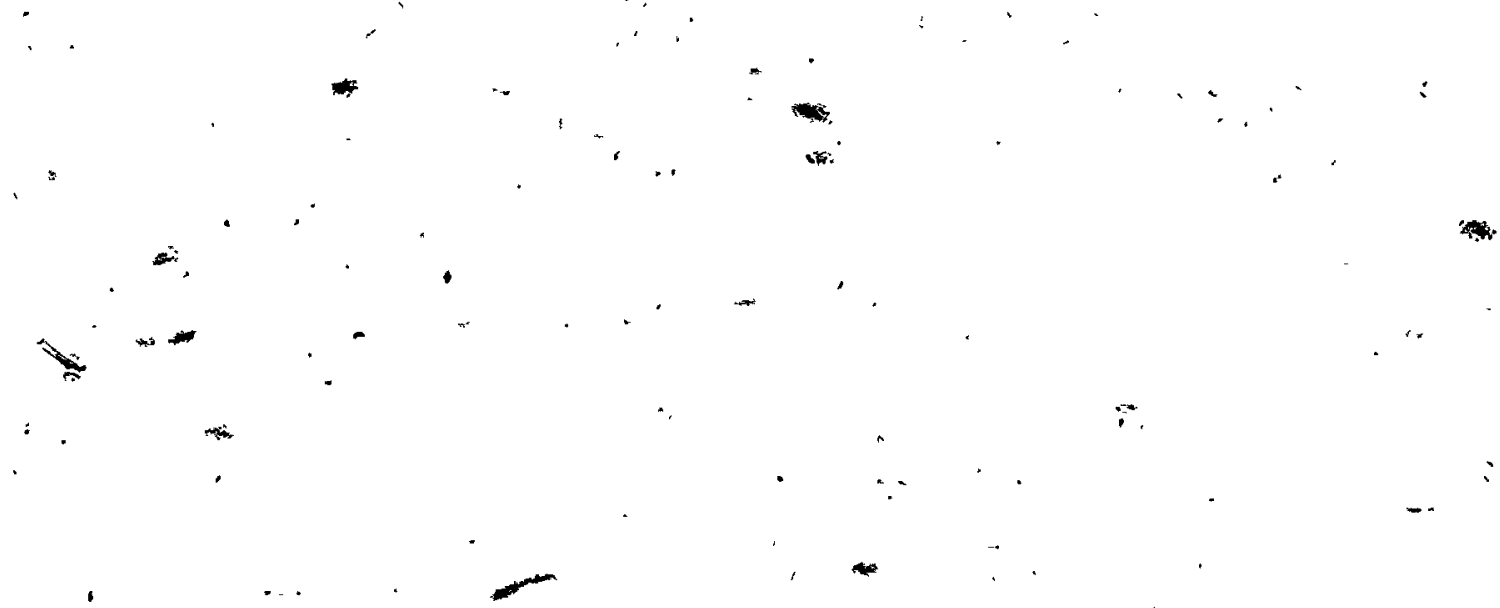

$\pi$

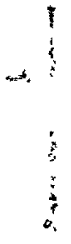




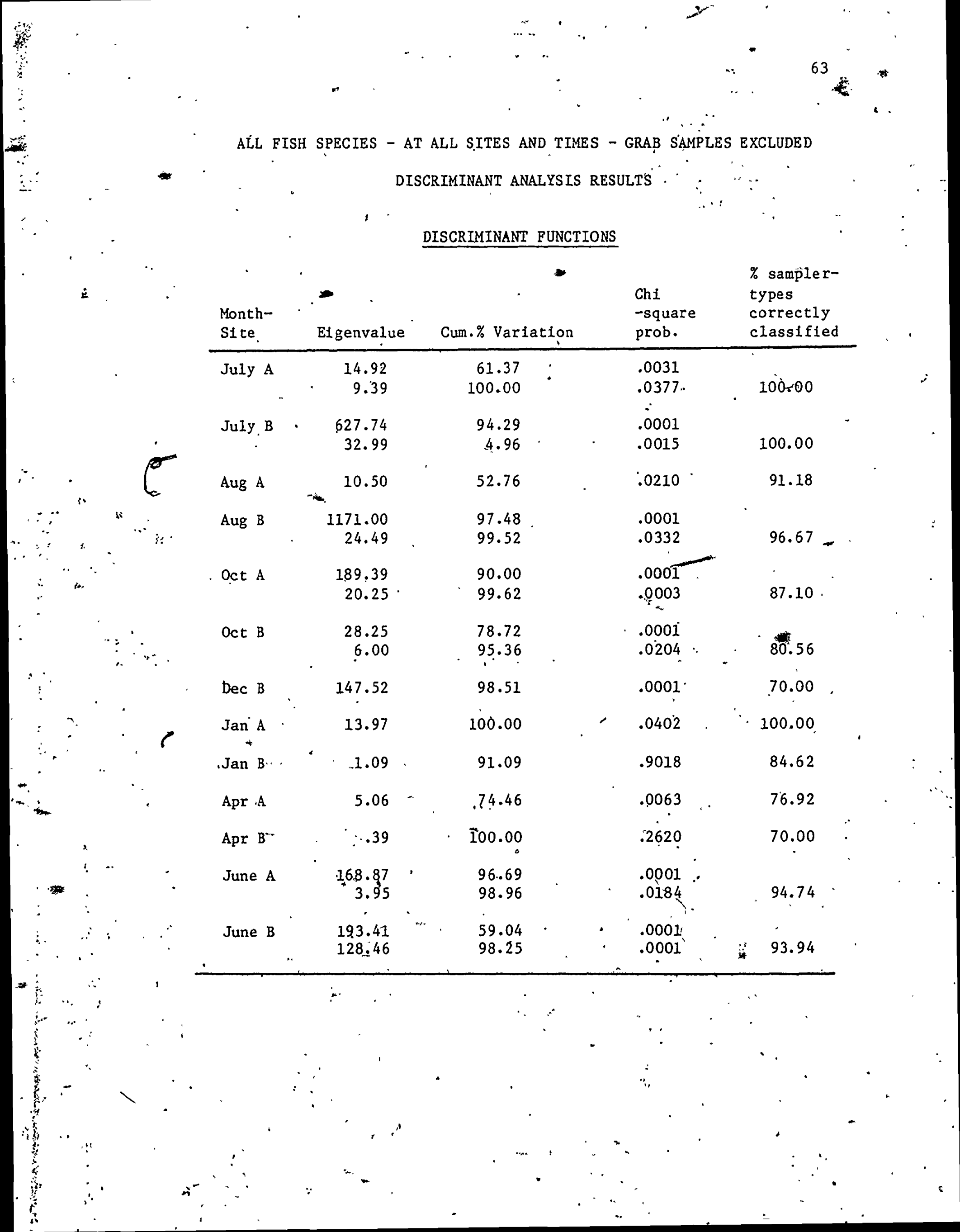


January and Apri1) or during August (site A) and actober. (site

- B). In most cases niche overlap among two or more predators was the result of the sharing of many prey species. - This makes it difficult to develop a direct link between benthic change and changes in niche overlap among predator species. For instance, winter flounder in August (site A) and Octóber (site B) 'share similar abundances of almost all prey species with cod and platce (Table 3.5; Appendix VIII). At most other times and sites there was at least one prey species that was consumed in greater abundances by winter flounder (eg. N. nigripes - July 'B; $\underline{\text { n. }}$ fraglis - October A). Ocean pout and witch flounder differ from the other predators in August and October; ocean pout because it consumes mollusks ( $\underline{Y}$. sapotilla,,$\underline{N}$ tenuisulicata) and witch

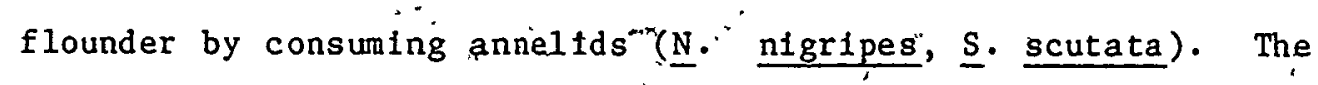
similarities between feeding patterns of ocean pout and plaice were traced to months when they both feed primarily on arthropods (Fig. 3.3*- October and June, site A) or an arthropod - annelid mix (June, site B). Unciola spp., D. quadrispinosa and $\underline{C}$. blgelowi were among the prey being shared (Appendix VIII).

3.3. Feeding behavlour of the Ocean Pout and Winter. Flounder

Observations of winter flounder and ocean pout feeding on a variety of natural prey intems provide an example of feeding methods influencing food resource division among syntoplc fish Fi:

(Appendix IV). The ocean pout sorts mouthfuls of bottom sediment to obtain infaunal prey species such as bivalves. The winter flounder relles more on vision to select prey exposed on the surface of the substrate. Winter floynder were also seen to. 
remove the viscera from shells of bivalves that presumably were too large to swallow; however, the required. increase. In hand ing time may make bivalves a suboptimal prey.

3.4 Prey species depth within the sediment

- Mean sediment depths at which prey are found differ significantly among prey species $(P<0.01)$. Ten samples were taken in June at site A only (Fig. 3.10). Amphipods, Ampharetids

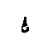
and scutata live in the upper sections of the mud and some " species of mollusks (Pitar morrhuana, Cylichna alba, and Periplome fragile) and Nemerteans (Micrura sp. and Cerebratulus sp.) in the lower sectrons ( $P^{\prime \prime} 0.05$, sNK multiple range test). - Yoldla sapotilla had a shallower mean depth than the other mollusks. The variances of the prey groups were homogeneous after Ln-transformation (Bartlett-Box $F$ test, $P<0.05$ ). The cumaceans samplëd were mainly $D$. quadrispinosà and the amph1pod category was $\underline{\mathrm{C}} .-$ blgelowi and Byblis gaimardi.

3.5 Rates of digestion of different prey

A visual index method of evaluating prey evacuation shows that polychaete worms followed by anphipods become unrecognizable before bivalves do. Factors to correct for varlability in digestion rates of prey (Table II - 4) were not applied to the stomach contents of fishes collected in this thesis. They show: the, degree to which variability of digestion characteristics among prey species can affect the researcher's perception of diet composition. Before corrections can be made to"stomach content data the digestion characteristics of more prey species at many , temperatures muṣt be made.' 
. 66 
67

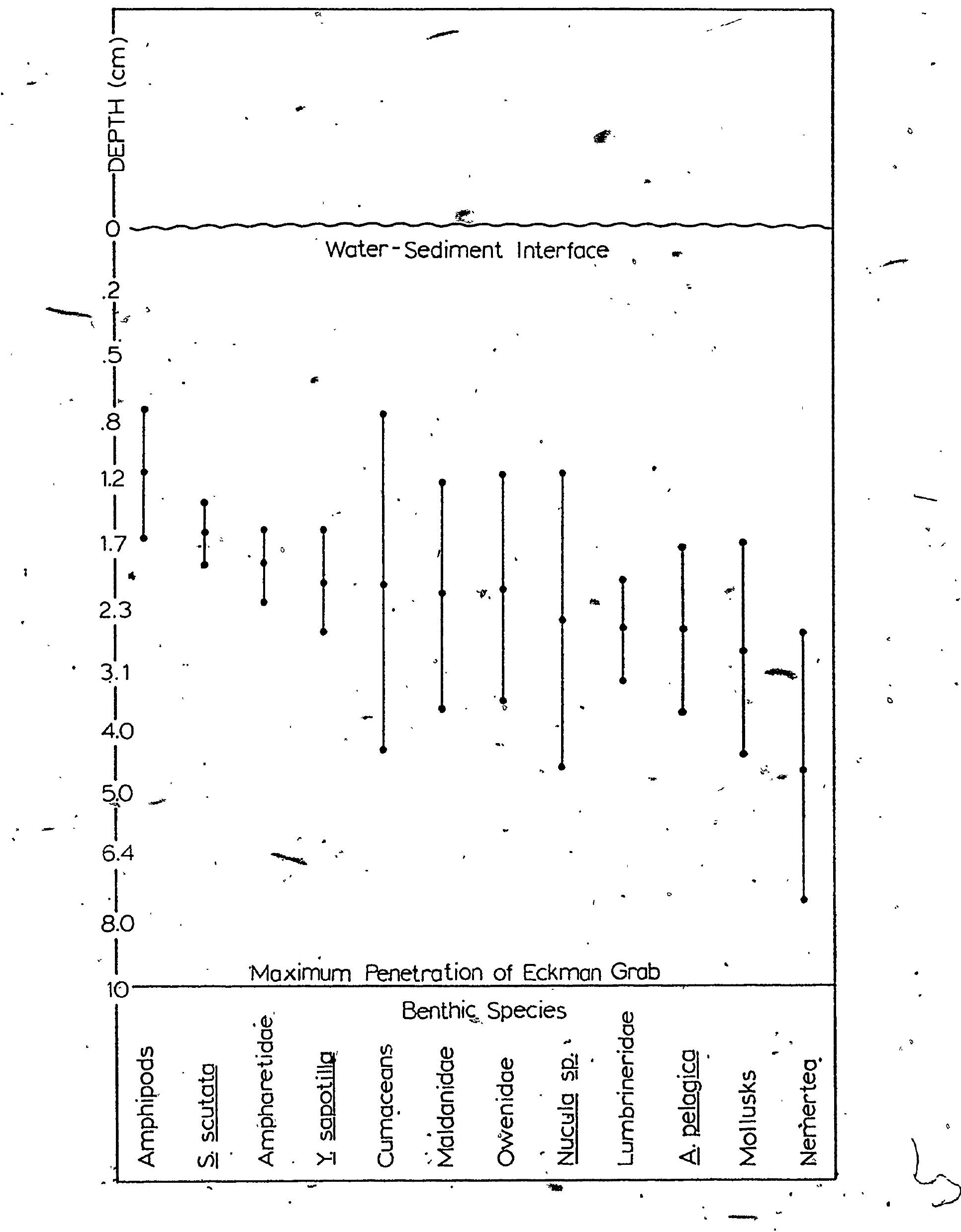


From plots of percentage of each prey recovered versus time * since feeding, it can be seen that annelids and amphipods were evacuated at a significantly greater rate than bivalves. of three models fitted to "the decay curves the exponential model gave the best overall fit to the data. However, a,linear model gave a good or better fit to the decay rate of the bivalve. The evacuation rates of different, prey should be considered when estimating daily rations of fish in their environments (Appendix II).

3.6 Feeding chronology and datly ration calculations

Using three methods to estimate feeding periqdicity discussed in Appendix III, it was found that winter flounder, plaice and ocean pout are' diurnal feeders with plaice feeding more heavily - later in the'day. Cod show no change in feeding activity with time of day: winter flounder and cod consume the most food per gram of fish followed by ocean pout and plaice. The winter flounder dally ration estimate $(1.65 \%$ body wt $/$ day) was similar to the 'estimates of ryler and Dunn ( $2 \%$ for dally fed fish) and Huebner and Langton $(1.8-2.4 \%)$ for laboratory studies Huebner and Langton $(1.8=2.4 \%)$ for laboratory stcudies at similar temperature." 


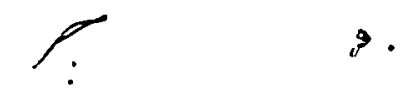

\section{- 4. DISCUSSION}

4.1 Annual Feeding Cycles

It is likely that cooler temperatures and approaching spawning times are responsible "for the decrease in feeding activities of" winter 'flounder, acean. pout and cod during the suonths b̆etween Decémber and Apr11 (FIg. 3.2). Similar responses have been recorded for plaice (Plèronectès platessa), cod, and flounder (Platichthys flesus) in the western Baltic (Arntz 19:4, 1978a, 1978b; Arntz and Finger 1981), dover sole (Microstomus pacificus) off Oregon* (Pearcy

$\because$ and Hancock 1978$)$, and wintèr flounder and ocean pout in the western north Atlantie (01sen and, Merriman 1946; Pearcy 1962; Richards 1963a; Tyler 1971; Hacunda 1979)- "These species first feed in A $\overline{\mathrm{pr}} 11$ or May when temperatures reach 3 or $4^{\circ} \mathrm{C}$ (Appendix I, Fig. 3:1). Seasonal sfood quantity trends were less evident for plaice

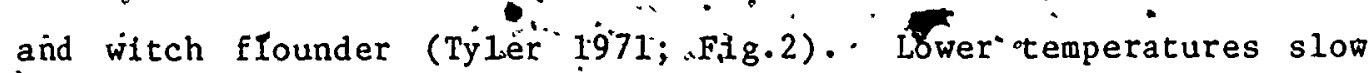
metabolism and Ingestion "rates, and reduce the amount of food - equired by all flishes in the winter community in the lower Bay of Fundy (Tyler 1970; Edwards 1971; Persson 1979, 1981).

- Comparisons of number of items per stomach among fish species a re misleading, (FIg. 3.2). "Mean sizes of the fish species (Table 2.1) and type of prey'specles eaten will affect daily ration estimates (Appendices IT, III).

4.2 Generai Feeding Habits

$\therefore$ Literature reports suggest that demersal fish spectes' food habits vary from region, to region. Wtater flounder feed primarily on polychaetés (Richards 1963a; 1963b; Tylër 1972;" "Langton" and Bowman 1981), molitusks and amphipods in the New England regions ..." 
(Frame 1974), and amphipods and polychaetes in the Bay of Fundy region (figure 3.3) - Ocean pout feed on ectinoderims ạnd crustaceans

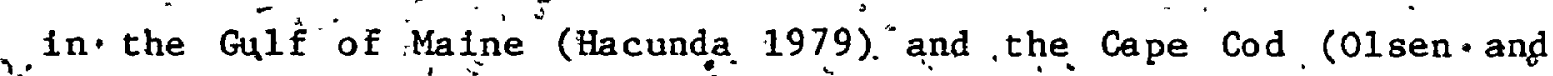
Merriman 1946) regions. ' They. feed primạrily on môtlusk's in . Passamaquaddy. Bay (Tyler 1972). Plalce feed "on mollusks, Éshes ando crustaceans in the western Baltic (Arntz I981) and Passamaquoddy Bay ( Tyler iğ2), polychaetes, of soythern few England (Bowman 1981a, '1981b) and echinóderms on the' Grand Banks (Macdonald unpublished).

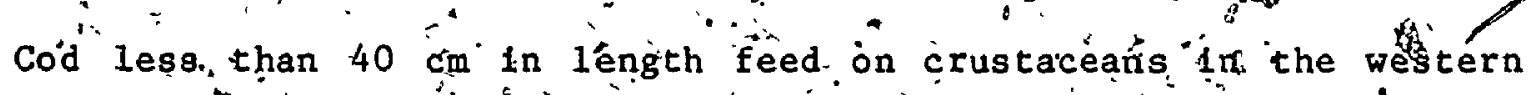
Baltic and trię northwestern Atlantic. Fishes and mollusks become Increasingly. 1mportant ta cod as they grow (Powles igso; Tyter 1972; "it Arntz 1974; Hacunda 1979; B Bownan ighola): DeGroot (1971) describes the witch flounder as a polychaete, mollusk and amphipod feeder in the North Sea.. They feed primarily on arnelids of the New Englahd

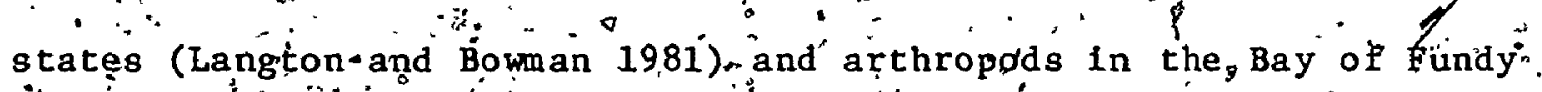
(E1g. 3.3\%. Jartation in the size of each fish species collected in each A : $3.370, \ldots$ study, and perhaps différences in feeding behaviqur among years and inyartes of evacuajtion among-different prey spectes, partially explain the differences in food habits repledted the literature -(Appendix If - Table 4). "Họever, demersel fushes gre'opportunistic feeders: and therefore food habit differences among different studies are primartiy the result of differences in the avaliable food source

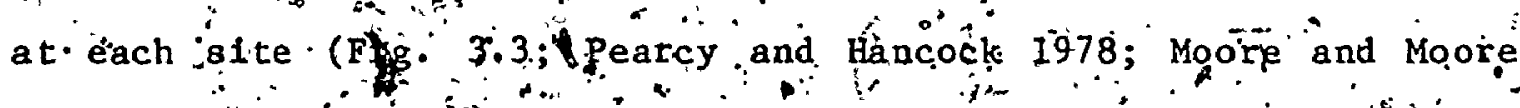
(1978a). Séasónal and spatial changes to diéts are bst examined after spatial and temparal changes on the bentic composition are d.1sćcusied 


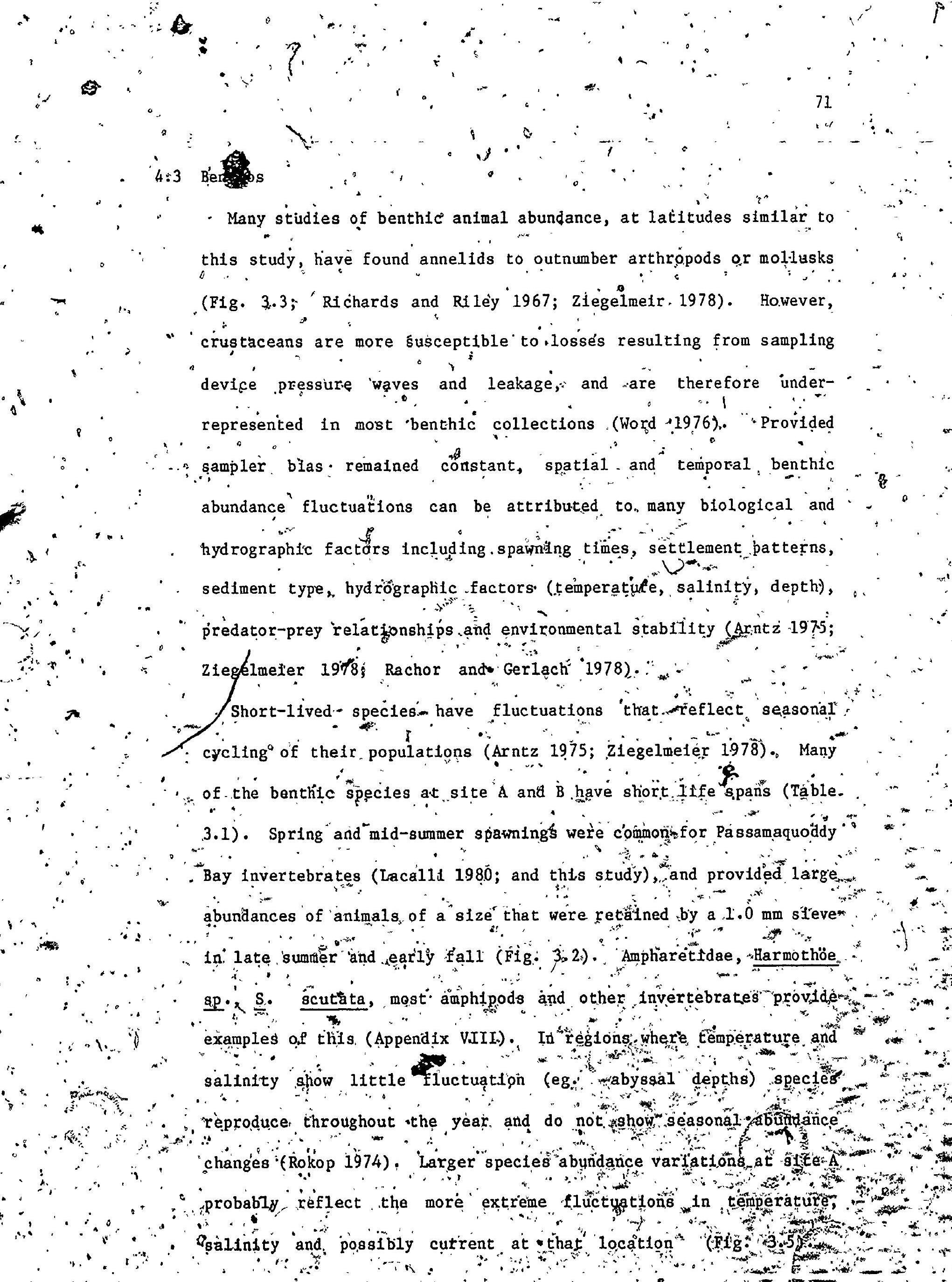




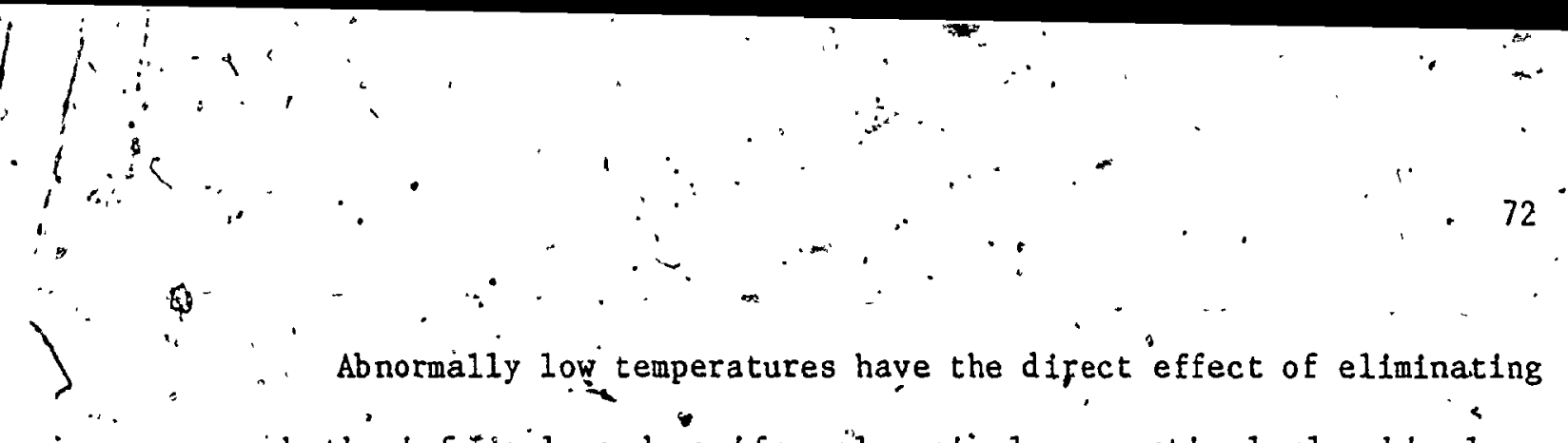
both' Infạuinal and epifaunal animals, particularly bivalves (Zlegelneter 1978). More extreme yearly temperatures may explain the lower densities of bivalves at site A (Appendix I- Fig. 2, 'Fig. i

(3.3). Other spatial faunal composition differences may.reflect depth and sediment typexdifferences., Sediments become coarser with decreasing depth and fincreasing currents (site A; McIntyre 1978). Arntz and Brunswig (1975) found the highest faunal diversity. to occur in conditions stailar to those at the northern half of site $\dot{A}$ (Fig. 2.1). However, while individual physical features undoubtedly control spatial, and temporal benthic patterns, the critical controlling factor is the degreg of envitonmental stability. Sanders (1968) has shown how all communities are a result of the r physical and biological components. Physical conditions are of primary importance, when each. specties has to adapt to" a "broad spectrum of phyștcal" changes', To survive, each spectes must utflize large portions of the environment and therefore fewer specles can Texist than when physlcal cọndityons are more constant. "With constant physical conditions blological interrelationstips develop" and community control occurs through biological accommodation. Blologically accommodated communties usually have a higher species diversity вoth sites were primarily controlled by physical hydrographical conditions (currents" and fluctuations in temperature and salinfty). Levinton: (1972), Rachor and Gerlach (1978) and Rhoads et al (1978) have shown how extreme temperatures and wind, wave:and current exosion can prevent successionary advancement to a later successtonary stage. 'The. faúna of early 
successionary stages feed on newly settled or suspended organic matter (bacteria) by filter feeding or surface deposit féeding "(Rhoads et al 1978). Both sites had many animais with these "feeding strategies (eg. S. scutata, Nucula spp., most small crustaceans, Ampharatidae, Owenidae; Table 3.1). Fewer sub-surface déposit feeders and carnivorous species, which are common in later successionary stages, were, present (eg. : Nephtys sp., Glycertd - Pectinerids, Lumbrinertds). The fauna at both sites show other $r$ selected characteristics that are common to colonizing species, Most animals were small, had high reproduction rates, high dispersability and short life spans (Table'3.1; Odum 1971; Levinton 1972; Rhoads' et.al 1978; Wildish 1980).

Many pioneering species live near the sediment surface and are therefore more susceptible to fish predation and wave erosion (eg. S. Scutata, Ampharetidae, 吕 sapotilla, Maldanidae; Fig. 3.10.. Rhoads et al 1978). Most of these antmals are surface suspension or deposit feeders. Many deeper animals are subsurfăce deposit feeders (Lumbrineridae, Nucula sp. and Nemerteans) or filter feeders (‥p morrhuana, $-\underline{P}$ fragile). Despite their depth Rhoads describes many as ploneering spectes.".

- Unfortunately measurements of the depths at which animals live in the sediment were made only at one site and time: Seasonal depth variation was not measured. Reading and McGrorty (1978) found Macoma balthica to be deepest in the winter. "Th1s. may be an evolutionary response to avold the eroding effects of winter storms and bird predation. s. : $?$ and $\because$ It is difficult to detect successional stage differences betwoen 
. 6

sites because little information is avallable on feeding methods and habitation depths of many of the invertebrates. Si te $B$ may support species that are at a higher successlonary stage. It has slower currents, fewer extreme hydrographic factors, more cionsistent sediment structure and was deeper so less susceptible to wave erosion. Surfáce feeding animals (eg. amphipods) were less abundant at site B. The dominant amphipod at site $B(\underline{C}$. bigelowi) was a large relatively long-lived species which shows other) K-sel'ected characteristics. - It can rework sediments to depths of $20-25 \mathrm{~cm}$ (Wildish 1980). The fish species assemblage was more sedentairy at site B than at site. A (Appendix I). However, site A had a. higher species diversity than site. B which is a characteristic of biologicaliy accomodated, stable compunities, that are at later.". successionary stages.

- 5 Site A was a better fish feeding ground. The benthic antmals were more abundan (Fig. 3.2) and potentlally .lived shallower in the !sediment. Ámphlpods; which were more abundant at site $A$, have higher.caloric values than most other prey species (Tyl 1973). A - great number of demèrsal fishes make seasonal migrations into Passamaquoddy Bay (s1te A) to feed (Appendix-I).

The degree to which fish feetiging affects the benthos is of Interest to manys researchers: (Huebiner and Langtón $1981 ; \mathrm{J}$. Grassle and M.J. Dadswell pers.comm.)!' Richards (1967), Levings (1974) and Arntz and Brunswig (1975), have found, the density of a few prey. ispecies populations to be reduced' by demersal flsh predation. Accurate estimates of fish predation, expressed as a percentage of benthic production, are happered by lack of autecological knowledge 
of many of the common-prey species. Important parameters are fecundity, death rates and growth rates. Year-round daily ration estimates are required for the predators as well." There are many demersal predators at both sites, 1ncluding fishes (Appendix I) echinoderms and carnivorous polychaetes. Communities with a large number of carnivorous invertebrates are poorer fish feeding grounds because a large portion of the available benthic energy flow goes to the - Inyertebrates (Richards 1967; Mills 1975). Fish-benthos interactions are considered below but at this stage ft will suffice to say, that while fishes may have an effect on some components of the benthós, the benthos at both sites is held at an early o successionary, highly productive stage. by varíable physical cond

conditions. Fluctuating temperatures, and 'ave and current actions, are almost certainly more, fimportant in regulating spatial and temporal benthic spectes abundance and diversity than are predatory fishes.

,

4.4 'Resource Utilization and Partitioning

Dermersal fish in many parts of the world consume fewer. polychaetes and more amphipods than would be expected from benthic samples (Fig. 3.3, Appendix VIII, Pig. 3.7, Table 3.5; Arntz 1978Kdel Bay; Rjchards 1963 - Long Island Sound; Moore and Moore 19.76a - : Severn Estuary): However, the researcher's, view of what is apparently available. is quite different - From what is potentially" ayaliable to each fish spectes (Hyatt 1979). A PONAR grab and a fish's mouth are qufte different sampling devices. "Predator spectes will respond in a variety of ways to differences in distribution;" - escape response, degree of concealment and size of prey spectès. 
The efficiency of the predator's digestion characteristics and feeding methods toward each prey type will determine, what is 'observed by the researcher as stomach contents (Steven 1936; Moore and Moore 1976a; Jones 1978; Robb 1981; Appendix II; IV).

Invertebrates that were distributed just below the sediment

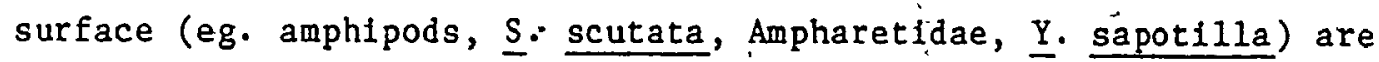
more likely to be fed upon than those that are deeper. Moore and Moore (1976b) speculate that a burrowing polychaete may be difficult for a predator to find and remove. Peiriploma fragilet, deepdwelling mollusk, occurred in large numbers at site $B$ but was neyer consumed by fishes. "The shallower $\underline{\underline{y}}$ : sapotilla was. consumed in large numbers by most fish species. It was the only mollusk consumed regularly by winter and witch flounder (Fig. 3.10, Appendix. VII.I.). Reading and McGorty (1978) found the sediment depth of Macoma balthica $=0$ be the factor that controlled predation rates of wading birds.

Epibenthic invertebrates (mysids, 's euphausilds, decapods's use underwater vegetation and other 'obstacles for protection. Nightly vertical migrations by benthic species, are probably timed to avoid the peak feeding actipity of visual predators. However, early a. morning and late, evening feedling activgty by fish may take advantage $\therefore$ of vertical migrations by prey spectes (Arntz 1975; Table 3.1). In the , lower Bay of Fundy non-visual feeders (ocean pout) may consume large' numbers. of Diastylis spp. at this time (Appendices III, IV, VIII).

Much of the food resource partitioning and food "selectivity" obperved in. demersal fish feeding studies 1s', correlated with 
4

differences in the morphological adaptations and feeding behaviour of each fish species (Brian. 1957; DeGroot 1971). Visual feeders

- such as cod and pleuronectids respond to prey movement and therefore feed on eptbenthic and shallow infaunal items (eg. arthropods; Brown 1969; Jones 1978; Ringler 1979; L1bey and Cole 1979; F1g. 3.3; Appendix IV). Ocean pout sort mouthfuls of sediment and thus have access to deeper infaunal material (most mollusks). Cod and winter flounder will eat infaunal material, the cod by digging and the flounder by nipping off siphons or crushing the shells (Bishop and? Odense 1966; Frame 1974; Appendix IV). Winter flounder mouths are too smaill to consume large whole objects. Shells must be completely broken down before they can pass through the narrow pyloric sphincter of cod. The extra time required to handle mollusks makes ther' suboptimal prey to cod, winter flounder and probably witch flounder (Appendicés IF and IV). Plaice have larger mouths and therefore are able to consume more mollusks than other pleuronectids (Fig. 3.3, Appendix VIT̃I): They eat large quantities of large calcareous prey on the. Grand Banks (sand dollars and sea urchins, Macdonald - unpublished) and fish in Kiel Bay (Arntz and Finger $1981)$

Calcareous and to a lesser extent chitonous prey were evacuated -at a slower rate by most predators and will therefore appear to be. eaten in greater numbers than they actually weré. Removal of this bias could reduce, the degree of food niche overlap that exists. between the annelid-anthropod predators and the mollusk predators (Appendix/II - Table 4: Fig. 3,9). 
4.5 Feeding reactions to spatial and temporal benthic shange

Generally the utilization pattern of benthic prey by each demersal fish.species is correlated 'with the abundance of prié in the sediment: This is particularly true when comparing dietary patterns among predator groups that have signiflcantly different, avalláble food resources such as site A vs site B (Table 3.2). Many annelids (Ampharetidae, P. ṕraetermissa, 热 1mbricata, s.'scutata), anthropods (C. bigelowi, L. pinguis, Unciola spp. Diastyils spp:) and mollusks (Nucula spp.) were consumed in greater abundances at the sites and the times that they were more abundant in the sediment (Appendix VIII). However, demersal fishes to not specialize at the spectes level. Rather theg consume food of a general type. For instance, oceän pout eat cumaceans at both sites. At site they eat. D, quadrispinosa and D. sculpta where they have a higher benthic abundance than site. A. At site B they eat $\underline{D}$. cornuifer which is the imore abundant cumacean there. Winter flounder eat amphipods at both sites. At site A they consume the dominant L. pinguis, at site $\dot{B}$ the dominant $C$. bigelowi.

1 Feeding methods may 'have a direct effect on predator specles' reactions ta. changes in prey, species density. Predators that use "visual cues to feed (eg. winter and witch flounder; Appendix IV) are Iikely to develop search limages towards' commonly utilized prey species (Tinbergen 1960). The functional responses of one or both of the flounders to high densities of $\underline{L}$. plnguls, ' $\mathrm{C}$. bigelowt and Ampharetidae, are explained by, search image. development (Appendix VIII; F1g. 3.8; Table 3.5). Non-v1sual feeders (eg. ocean pout) are less likely to develop search images (RIngler 1979). Thethr 
predation rate is likely - to' remn-constant ith increasing". densities of prey animals.

Some seasonal prey utilization patterns were, not related to : changes in potential prey species density. Changes in size of benthic animals can also be responsible for dietary shifts (Pearcy 1962; Levings 1974; Moore and Moore 1976a; -Arntz 1974; 1978a). According, to optimal foraging theory, the predator will ignore small prey where the yield in energy per unit foraging 'time is low. Since energy content increases with size of prey (Kerr 1979) there exists a prey size where, the ratio of energy gained to' time spent foraging is maximized (MacArthur and Planka 1966; Krebs 1978). Larger prey will also be more visíble. For example, L. pinguis was more heavily utilized by most fishes when it was largest in spring. Yoldia $\frac{\text { sapotifla }}{l^{2}}$ is more heavily utilized by winter and witch flounder and ocean pout when $1 t$ is largest in the summer. Casco bigelowi is more hedvily utilized in the summer when it is largest, by platice and winter flounder (Fig. 3.4, Table 3.5, Appendix VIII). These shifts were not caused by benthic antmal density changes. In fact $\underline{Y}$. sapotilla and $\underline{\text { L. pinguts }}$ are more abundant during the times of year when predation pressure is minimal. Therefore demersal fishes may play a role in controlling, population levels of a few common species, as Levings (1974). found, but predatign impact on most benthic species is negligible (Richards 1963 and Arntz 1978b had similar concilusions).

$\therefore$ The upper limit to population size of many marine' demersal fish species is determined in.the first year of life (Jones 1978). It is therefore unlikely that food is a limiting resource for older fish: 
If food were limiting, then optimal foraging theory would predict that the fishes on the poorer site (site B), would have more diverse diets (Warner and Hall 1974). Si te B had fewer animals and in particular fewer energy rich spectes such as amphipods. However, there was no differénce in the diversity of prey consuned by each predator (Fig. 3.1, 3.3).

Increase in availability of potential prey specles has been shown to Increase the degree of overlap among predatory fishes (Zaret and Rand 1971; Sedberry and Musick 1978; Pearcy. and Hancock 1978; Ringler 197.9; Macpherson 1981). In Passamaquoddy Bay the demersal fishes at both sites" show significant food resource segregation (Fig. 3.9; Tyler 1972). The greatest diet overilap observed in this study occurred in August (site A) and October (site B) when benthic density and diversity was highest (Fig. 3.1, 3.2, 3.9). Other factors, such as dally feeding times (Appendix III), spatial and temporal varlation in predator abundance (Appendix I) ahd vertical differences in areas of feeding activity (Johansen and Ringler 1980), may serve to reduce nichè overlap particularly among winter. floundèr, plaice and cod in August (site A) and October (stee B). However, these three species are found together in large abundances at these sites and times (Appendix I - Table 2). It is likely that food type is the major niche segregating factor. similar. conclusions have been made by Gascon' and Leggett (1977), Keast (1978), Kravitz et al (1976) and Macpherson (19181). 
5. CONCLUSION

Seasonal movement of the fish species in the lower Bay of Fundy 1 region was largely from an inshore, shallow water locality in summer to an offshore, deep water locality in winter with a reverse movement occurring in spring (Appendix I). The cause of this movement may have a large physiological component related to temperature effects on the osmoregulation of, many marine fishes. Juvenile fishes of many species $\leq "$.

use the shallow water habitat as a nursery area. "Thenare susceptible to" coastal impacts from development, degradation, and pollution.

Analyses of 'systems as complex as this lend themselves well to multivariate statistical modelling techniques' where the object is to explore data structure rather than make formal statistical tests at specified probability-levels. Discriminant gnalysis and multi-factor MANOVA are appropriate methods to explore food composition differences among groups of fish species collected at different sittes and timés. Prey species which contribute most to group differentiation äre more gasily identifled using the variable reduction method developed by Jancey (1979) 'than by using varlable loadings on discriminant functions, Numbers of prey measurements (not weight) were used in the analysis? Additional information galned decreases rapidly as more measurement variables are Included (Appendix V).

Differences in diets among 'fish specles is the major 'niche' segregating fattor. Other factors, such as daily feeding times (Appendix III) and spatial and temporal varfation in "predator abundance (Appendix I) are less important.

$\therefore$ - Fishes do not "prefer" and "select" specific prey in the deliberate sense of the words. Rather, food speclallza,tion and dietary niche 
separation are $\bar{a}$ result of evolutionary development of unique feeding behaviours, digestion morphologies and techniques, and mouth structures which interact with the size, behaviour, distribution and abundancë. characteristics of certain types of avallable benthic fauna. For instance the development of techniques to feed and process infaunal food: efficiently partially explains the predominance of mollusks and sedentary

polychaetes in the diet of the ocean pout (Appendices II and IV). Visual feeders (winter flgurder, cod, plaice, and witch flounder) are more likely to consume epibenthic iprey. Ás"a result many demersal fish species segregate, the resource by having somewhat specialized food habits. However, this also cope with spatially and temporally, changing food resources and therefore specialize'ln general prey typés, not 'prey species.

The perception of the diet composition and consumption rates. that fishes have in the natural environment, and our models for describing the 'digestion processes, are affected by variability in the digestion characteristics of each prey spectes (Appendix II). Analysis of consumption rates' requires that the rate of weight loss by the prey be -applied to the model, which best describes the digestion process. it is unlikely that food is a limfting resource to demersal.fishes In the lower Bay of Fundy region because: a) the upper $11 \mathrm{mit}$ to populationrsize. is probably set in the. first year of $1 \cdot 1 f \dot{e}$, b) only a few prey species show density changes as a result of predation and c) spatial and temporal benthic density changes observed in this study are largely “due to pirysical perturbations. 1.. Further work is required to estmate the production of common - befthic species/and the datiy rathons of fighes throughout the year so" 
$\therefore$
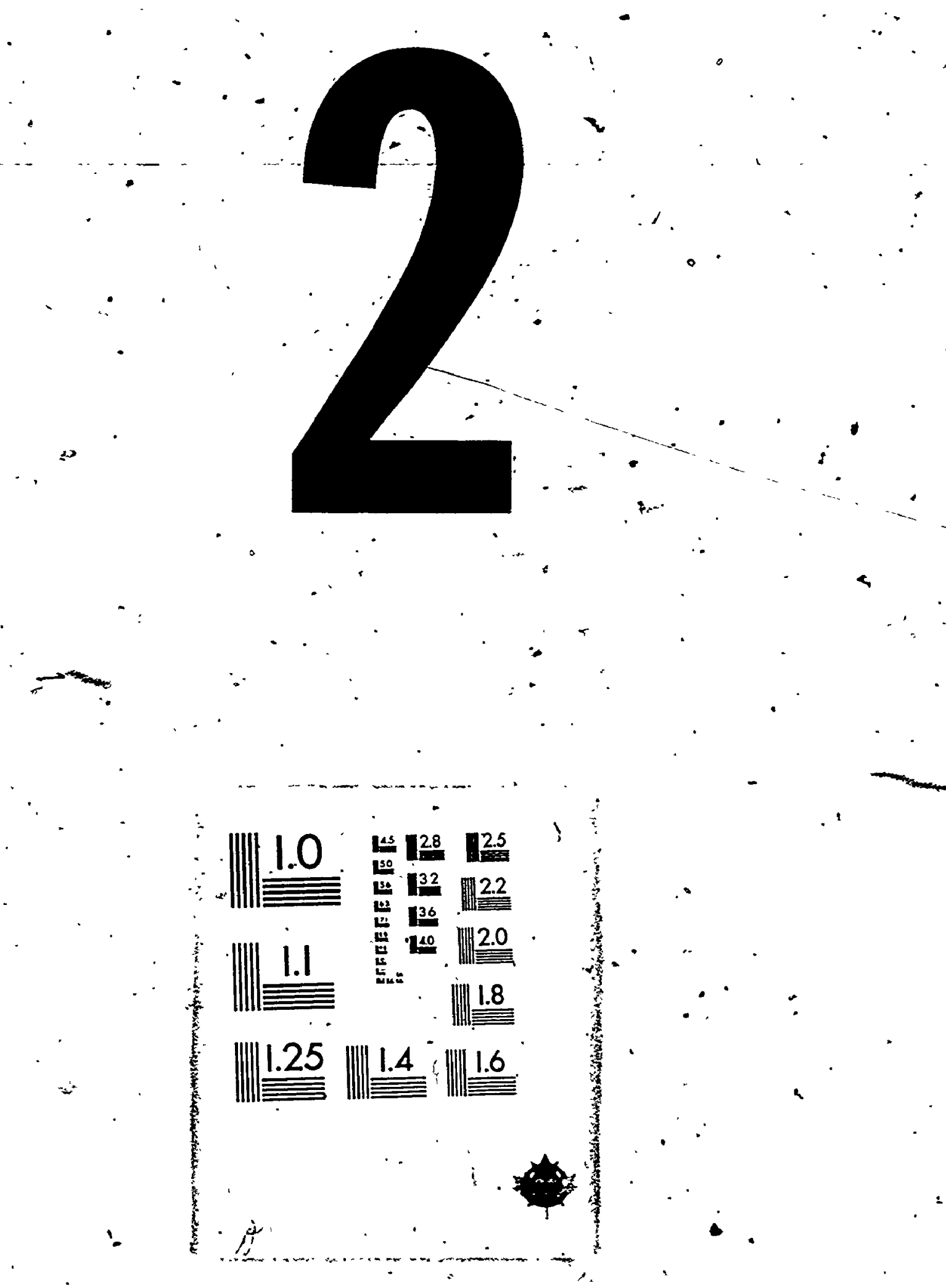

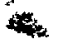




\section{REFERENGES}

ABBOTT, R.T. 1974. American Seashells (2nd ed.).

Van Notrand ReInhold Co., Toronto, Ont. 663p.

APPY, T.D., L.E. Linkletter, and M.J. Dadswe11, 1980. A guide to the marine flora and fauna of the Bay of Fundy: Annelida: Polychaeta.'

F1sh. Res. Board Can. Tech. Rep. 920: $124 \mathrm{p}$.

ARTTZ, W.E., 1974. A contribation to 'the feeding ecology of juventle cod

(Gadus morhua L.) in the western Baltic. Rapp. P. -V. Revun. Cons. int. Explor. Mer 166: 13-19.

ARNTZ, W.E., 1978a: The food of adult cod (Gadus morhua L.) in the western Baltic. Meeresforsch. ,26: 60-69.

ARNTZ, W.E., 1978b. Predation oh benthos by flounders, Platichthys flesus (L.) In the deeper parts of Kiel Bay. Meeresforsch 26: 7078.

ARNTZ, W.E., 1978c. The "upper part" of the benthic food web: the role of macrobenthos in the western Baltic." Rapp. P. -V. Reun. Cons: int." Explor. Mer, 173: 85-100.

ARNTZ, W.E., and D. BRUNSWIG, 1975. Studies on structure and dynamics of macrobenthos in "the western Baltic carried out by the joint research programme "Interaction. Sea - Sea Bottoin". 10th European Symposium in Marine Biology. 2: $17-42$.

ARNTZ, W.E. and I. FINGER, 1981. Demersal fish in the western Baltic: . their feeding relations, food colnctdence and food selection. International Council for the Exploration of the Sea C.M. 6: 28p. BAKANOV; A.I., and L.N. STRIZHNIKOVA. 1979. On the relation between changes in the food supply and the feeding of the eastern bream 
(Abramis brama orientalis) in the Volga Arm of Rybinsk reservolr. J. of Ichthyology 19: ifig-126.

BARNES, R.D., 1968. Invertebrate Zoology (2nd.ed.). W.B. Saunders Co., Toronto, ont. 74lp.

BERG, J. 1979. Discussion of methods of investigating the food of fishes, with reference to a preliminary study of the prey of Bobiusculus flavescens (Gobildae). Marine Biology 50: 263-273. BISHOP, C., and H. H. ODENSE. 1966. Morphology of the digestive tract of.. cod, Gadus morhua. J. F1sh. Res. Board Can. 23: 1607-1615. BLEGVAD, H. 1928. Quantitative investigations of bottom invertebrates in the Limfjord 1910-1927 with spectal reference to the platce food. Rep. Dan. biol. Stn. 34: 33-52.

BOWLES, J.E. 1970. Engfineering properties' of soils and their measurements. McGraw-Hiliz Toronto. $187 \mathrm{p}$.

BOWMAN, R.E. 1977. Seasonal-food habits of demersal fish in the N.H. Atlantic - 1972. N.0.A.A. Data Report 77-01: 31p.

BOWMAN, R.E. 1980. Food of Silver Lake (Merluccius bilinearis). Lab. Rèf. Document 80-31; 46p.

BOWMAN, R.E. 1981a. Food of 10 species of northwest Atlantic juvenile 'groundfish. Fish. Bul1. 79: 200-206.

BOWMAN, R.E. 1981b. Stomach contents of 24 species of fish caught in - Cape Cod Bay/or Massachusetts Bay during the period 1972-1978. Lab. Ref. Document 81-14: 34p.

BRAWN, V.M. 1969. Feeding behaviour of cod (Gadus morhua). J. Fish. Res. Board Can, 26: 583-596.

BRIAN, A.D. 1957. Differences in the flowers visisted by four species of 'bumblebees and their causes. J. An 1m. Ecol. 26: 71-98. 
BRINKHURST, R.O., L.E. LINKLETTER, E.I. LORD, S.A. CONNORS, and M.J. DADȘWELL, 1976. A preliminary guide to the 1 ittoral and sublittoral marine invertebrates of Passamaquoddy Bay. Fish. Res. Board, Can, I.D: Centre Pub. St.Andrews, N.B: $166 \mathrm{p}$.

COLWELL, R.K., and D.J. "FUTUMMA. 1971. On the measurement of niche breadth and overlap. Ecology 52: 567-576.

DeGRôoT, S.J. 1971. On the inter-relationships between morphology of the alimentary tract and food and feeding behaviour in flatfishes (Pices: Pleuronectiformes). Neth. J. Sea Res. 5: 121-196.

DESSELLE, W.J., M.A. POIRRIER, J.S. ROGERS and R.C. CASHNER. 1978. A -discriminant fugctions analysis of suntersh (Lepomis sp.) foodhabits and feeding niche segregation in the Lake Pontchartrain, Louisianna Estuary. Trans. Am: Fish. Soc. 107: 713-719.

EDWARDS, D.J. 1971. Effect of temperature on rate of passage of food through the alimentary canal of the plaice pleuronectes platessa. J. Fish. Biol. 3: 433-439.

ELLIOTT, J.M.,. 1977. Statistical analysis of samples. of benthic - Invertebratés. Sc1. Publ. No.25, Freshwater Biological Association, Ferry House, U.K: '160p.

ELLISON, J.P. 1978. The use of discriminate analysis in the study of fish, food habits, p.80-86. In S.J. Lipoysky and C.A. Simensted - [ed.] Fish food habit studies 2nd Pacific N.W. tech. workshop. Proceedings. Untversity of Wash., Wash.

FEINSINGER P., E.E. SPEARS and R.W. POOLE. 1981. A simple measure of niche 'breadth. Ecology 62: 27-32'.

FEWSTER, P., and L. ORLOCI, 1978. Stereograms to ald group recognition and trend identification in vegetation data. Can. J. Bot.,56: 162165. 

HUEBNER, J.D., and R.W. LANGTON. 1982. Rate of gastric evacuation for winter flounder (Pseudopleuronectes americanus, Walbaum) 'Can. J. : : Fish. Aquat. Sc1. 39: 356-360:

HYATT, K.D. 1979. Feeding Strategy. In W.S. Hoar and D.J. Randall [ed.] Fish physiology. Academic Press, New York 8: 71-119.

IVLEV, V.S., 1961. Experimental ecology of the feeding of fishes. Yale Univ. Press, New Haven, Conn: 302p.

JACKSON, P.D. 1978. Benthic invertebrate fauna and feeding relationships of brown trout, Salmo trutta L., and river blackfish, Gadopsis mármoratus Richardson, in the Aberfeldy River, Victoria. Aust. J. Mar. and Freshev. Res. 29: 725-742.

JACOBS, J. 1974.. Quantitative measurement of food selection: . a modification of the forage ratio and Ivlev's electivity index. Decologia (Berlin) 14: 4i3-417.

JANCEY, R.C:,' 1979. Species ordering on a variance critérion. Vegetatio 39: $59-63$.

JOHANSEN, P.H., and N.H. RINGLER. 1980, Diets of juventle coho salmon (Oncorhynchus kisutch and steelhead trout (Saimo gairdineri) relative to prey avallability. Can. J. Zool. 54: 553-558.

JOLICOEUR, P., and J.E. MOSIMANN. 1960. Shape variation in the painted turtle, a principal component analysis. Growth 24: 339-354.

JONES, N.S. 1952. The bottom fauna and the food of flatfish of the Cumberland coast. J. Anim. Ecol. 21: 182-205.

JONES, R. 1978. Competition and co-existance with particular reference to gadold fish species. Rapp. P. -V. Reun. Cons. Int. Explor. Mer, 172: $292-300$.

KEAST, A. 1978. Trophic and spatial inter-relationships in the fish 
species of an Ontario temperate lake. Env. Biol. Fish. 2: 53-70. KERR, S.R. 1979. Prey avallability, metaphoetesis and slze sitructure of lake. trout .stocks. - Invest Pesquera-43; 187-198.

KLECKA, W.R. 1975. Discriminant analysis. In statistical package for the social sciences (2nd ed.). McGraw-Hill, New York. $6 \dot{7} 5 \mathrm{p}$. KRAVITZ, M.J., W.G. PEARCY and M.P. GUIN. 1976. Food of five species of co-occurring flatfishes on Oregon's continental shelf. Fish Bull. 74: $984-990$.

KREBS, J.R., 1978. Optimal foraging: decision rules For predators, p.2363. In J.R. Krebs and N.B. Davies [ed.] Behavioural ecalogy. : Blackwelk Scientific Pub., Oxford.

LACALLI, T., 1981. Annual" spawning cycles and planktonic larvae of benthic invertebrates from Passamaquoddy Bay, New Brunswick. Can. J. Zoo1. 59: $433-440$.

LANGTON, R.W., and R.E. BOWMAN. 1980. Food of fifteen Northwest Atlantic gadiform fishes. N:O.A.A. Tech. Rep. 740: 23p.

LANGTON, R.W. and R.E. BOWMAN. 1981. Food of elght northwest Atlantif pleuronectiform fishes. N.0.A.A. Tech. Rep. 749: 15p.

LANGTON, R.W., and R.E. BOWMAN. 1981. Food of elght northwest Atlantic pleuronectiform fishes. N.0.A.A. Tecti. Rep. 749: 15p.

LEIM, A.H., and W.B. SCOTT, 1966. Fishes of the Atiantic coast of Canada. Fish. Res. Board Can. Bull. 155: 485p.

LEVINGS, C.D. 1974. Seasonà changes in feeding and particle selection by winter flounder (Pseudopleuronectes americans). Trans. Am. Fish.

LEVINTON, J.S. 1972. Stability and trophic structure in deposit-feeding and suspension-feeding communtites. Am. Naturalist 106: 472-486. 
LIBEY, G.S., and C.F. COLE. 1979. Food habits of yelllowtall flounder, $\therefore$ Limanda ferruginea (Storer). J. Fish, Biol. 15: 371-374.

LILLY, G.R., and A.M. FLEMING, 1981. Size relationships in predation by. :

Atlantic cod, Gadus morhua on capelin, Mallotus villosus and sand lance, Ammodytes dubius, in the Neqfoundiand area. NAFO Sci. Coun." Studies 1: $41-45$.

MacARTHUR; R.H., and E.R. PIANKA. 1966. On the optimal use of a patchy environment. Amer. Natur. 100: '603-609.

MACDONALD, J.S., and G.S. SUDBURY, 1982. Use of a digitizer to estimate length at age co-ordinates for yellow perch' (Perca flavescens) using a backcalculation procedure. Univ. of Hestern ont. Statistical Tech. Rep. TR-8,2-04: $10 \mathrm{p}$.

MacPHERSON, E. 1981. 'Resource partitioning in a Mediterranean demersal fish community. Marine Ecol - Progress Serieș 4: 183-193. MARRIOTT, F.H.C., 1974. The interpretation of multiple observations. Academic Press Inc., $\mathrm{NY}$ : $117 \mathrm{p}$

MEARNS, A.J., and D.R. YOUNG. 1978. Pollutant flow through marine food webs, p:107-117. S.J. Li povsky and C.A. Simenstad [ed.] Fish food habit studies 2nd Pacific N.W. tech. workshop. Proceedings. University of Wash., Wash.

MILLS, E.L. 1975. Benthic organisiss and the structure of marine 0 ecosystems. J. Fish. Res. Board Can., 32:-1657-1663. McINTYRE, A.D. 1978. The benthos of the western North Sea. Rapp. P. -V. Reun. Cons. Int. Explor. Mer. 172: 405-417. MOORE, J.W., and I.A. MOORE. 1976a. The basis of food selection in flounders (Platichthys flesus) in the severn estuary. J. Fish. B1ol. 9: 139-156. 
MOORE, J.H., and I.A: MOORE. 1976b. The basis of food, selection in some estuarine fishes. Eels, whiting, sprat and 'stickleback. J. Fish.. B1ol. 9: $375-390$.

NEWSOME, G.E., and J.H. GEE. 1978. Preference and selection of prey by - creek chub inhabiting Mink River, Manitoba., Cań. J. Zooí. 56: $2486-2497$.

ODUM, E.P. 1971. Fundamentals of ecology (3rd ed.). W.B. Saunders Co., Torontò, Ont: $574 \mathrm{p}$.

OLSEN, Y.N., and D. MERRIMAN. 1946. Studies on the marine resources of southern New England. IV. The blology and economic 1mportance of the ocean pout, Macrozoarces americanus (BIock and Schneider). Buil. Bingham Oceanogr. Collèct. Yale U. 9: 1-183.

OŔLOCCI, L., 1978. Multivarpate analysis in vegetation research (2nd ed.). W. Junk, The Hague. 451 p.

PEARCY, W.G., 1962. Ecology of an esturarine population of winter flounder, Pseudopleuronectes americans (Walbaum). IV. Food habits of larvae and juveniles. Bull. Bingham Oceangr. Collect. Wale U. 18: $1-78$

PEARCY, W.G., and D. HANCOCK. 1978. Feeding habits of Dover sole, Microstomus pacificus; rex sole, Glyptocephalus zachirus; slender sole; Lyopsetta exilis; and Pacific sanddab, Citharichthys sordidus, win a region of diverse sediments and bathymetry off Oregon. Fish. Bull; 76: 641-652.

PERSSON, L. 1979. The effects of temperature and different food organisms on the rate of gastric evacuation in perch (Perca fluvatilis). "Freshw. B101. 9: 99-104.

PERSSON, L. 1981. The effects of temperature and meal size on the rate 
of gastric evacuation in perch (Perca fluvialilis) fed on fishi: larvae. Freshw. Biol. 11: 131-138,

PETERSEN, C.G.J. 1914. Valuation of the sea. II. The animal communities of the sea bottom and their importance for marine zoogeography. Rep. Dan. biol. Stn: 21: 1-68.

PETERSEN, C.G.J. 1924. A brief survey of the animal communities in Danish waters, based 'upon quantitative samples taken with the bottom sampler. Am. J, Sci. 5: 343-354.

PIANKA, E.R. 1978. Evolutionary ecology (2nd ed.j. Harper and Row Rub., London: $397 \mathrm{p}$.

POWLES, P.M., 1958. Studies of reproduction and feeding of At lantic cod (Gadus callarias L.) in the southwestern, Gulf of St.Lawrence. J. Fish. Res. Board Can. 15: 1382-1402.

PRINCE, E.D., O.E. MAUGHAN, D.H. BENNETT, G.M. SIMMONS, Jr., J. STAUFFER, Jr., and R.H. STRANGE, 1979. Trophic dynamics of a freshwater artificlal tire reef, p.459-474. In R.H. Stroud and H. Clepper. [ed.] Predator-prey systems in fisheries management. Sport Fishing Inst., Wash. D.C.

RACHOR, E., and S.A., GERLACH. 1978. Changes of macrobenthos in a sublittoral sand area of the German Bight, 1967-1975. Rapp. P.-V. Reun. Cons. int. Explor. Mer 172: 418-431.

READING, C.J., and S. MCGRORTY. 1978. Seasonal variation in the burying depth of Macoma balthica (L.) and its accessibility to wading birds. Estuarine and Coastal Marine Sc. 6: 135-144.

RHOADS, D.C., P.L. MCCALL, and J.Y. YINGST. 1978. Disturbance and production on the estuarine seafloor. American Sclentist 66: 577586. 
RICHARDS, S.W. 1963a. The demersal fish populations of Long Is land Sound. II. Food of the juveniles from a sand-shell locality. Bull. Bingham Oceanogr. Collect. Yale U. is: 32-72.

RICHARDS, f.H. 1963b. The demersal fistr populations.of Long Is land $\therefore$ Sound. III. Food of the juventles from a mud locality. Bull. Bingham Oceanogr. Collect. Yale U. 18: 73-93.

RICHARDS, S.W., and G.A. RILEY. 1967. The benthic epifauna of long Island Sound. Bull. Bingham Oceangr. Coll. Yale U. 19: 1-136. RICKLEFS, R.E. 1979. Ecology (2nd-ed.). Chiron Press, New York: 966p. RINGLER, N.H. 1979. Prey' selection by, benthic feeders, p.219-229. In R.H. Stroud and H. Clepper [ed.] Predator-prey systems in fisheries management. Sport Fishing Inst., Wash. D.C.

ROBB, A.P. 1981. Observations on the food and diel feeding behaviour of pelagic 0-grp. gadoids in the northern North Sea. J. Fish. Biol. 18: $183-194$.

ROFF, J.C., 1978. A guide to the marine flora and fauna of the Bay of Fundy: Copepoda: Calanoida. F1sh. Res. Board" Can'. Tech. Rep. 823: $29 \mathrm{p}$.

ROKOP, F.J. 1974: Reproductive patterns in the deep-sea benthos. Science 186: $743-745$.

SCHOENER, T.W. 1975. Presence and absence of habitat shift in some widespread Ifzard speices. Ecol. Monog. 45: 232-258.

SEDBERRY, G.R., and J.A MUSICK. 1978. Feeding strategies of some demersal fishes of the continental slope and rise of the ridAtlantic coast of the U.S.A. Mar: Biol. 44: 357-375.

SMITH, R.I. [ed.] 1964. Keys to martine Invertebrates of the Woods Hole region. Contrib. No.11, Systematics - Ecology Program, Mar. Biol. 
$\therefore \quad$ Lab, Woods Hole, Maśs. 208p.

.SNEDECOR, G.W., and W.G. COCHRAN. 1980. Statistical methods (7th ed.). . Iowa State Univel Press., Iowa. 507p.

SOKAL, R.R., and F.J. ROHLF. 1969. Biometry. W.H. Freeman and Co., San Francisco. $776 \mathrm{p}$.

SOKAL, R.R., and F.J. ROHLF., 1973. Introduction to blostatistics. Freeman, San Francisco: 368p.

STEELE, J.H. 1974. The structure of marine ecosystems. Harvard Univ. Press, Cambridge. Mass: 128p.

STEIN, R.A. 1977. Selective predation, optimal foraging, and the predator-prey interaction between fish and crayfish. Ecology 58: 1237-1253.

STEVEN, G.A. 1936. Botton fauna and the food of fishes. J. Mar. Biol. Assoc. 16: $677-707$.

TEAL, J.M. 1962. Energy flow in the salt marsh ecosystem of Georgia. : Ecology 43: 614-624. '

TINBERGEN, L. 196.0. The natural control of insects in pinewoods, I: Factors influencing the intensity of predation bongbirds. Arch. Neer1. 2001. 13: 266-336.

TYLER, A.V. 1970. Rates of gastric emptying in young cod. J. Fish. Res. Board Can. 27: 1177-1189.

TYLER, A.V., 1971. Monthly changes in stomach contents of. demérsal fish" . , in Passamaquoddy Bay, N.B. Fish. Res. Board Can. Tech. Rep. $288: 80 \mathrm{p}$

TYLER, A.V., 1972. Food resource division among northern, marine, dermersat fishes. J. Fish. Res. Board. Can. 29: p.997-1003. TYLER, A.V. 1973, Caloric values of some north Atlantic invertebrates. 
Mar. B1. 19: 258-261.

HATWOOD, K.G., J. MAJKOWSKI and" G." KIETH. 1979. Food habit's and: consumption rates of cod from the southwestern Gulf of St - Lawrencer C.A.F.S.A.C. Res. Document 80/37: 17p.

WERNER, E.E., and D.J. HALL. 1974. Optimal foraging and the size selection of prey by the bluegill sunfish (Lepomis macrochirus). Ecology 55: 1216-1232.

WILDISH, D.J., 1980. Reproductive blonomics of 2 sublittoral amphìpods - in a Bay of Fundy estuary. Int. Journal of Invert. Rep. 2: 311320.

WORD, J.Q. 1976. An evaluation of benthic invertebrate sampling devices for investigating feeding habits of fish, p.43-55. In s.s. Liporsky and C.A. Simensted [ed.] Fish food habit studies lst. Paclfič N,W. tech. workshop. Proceedings. Unfversity of Wash.; Wash. 1

ZARET, T.M., and A.S. RAND. 1971. Competition in tropical stream fishes: support for the competitive exclusion principle. Ecology 52: 336342.

ZIEGELAEIER, E. 1978. Macrobenthos investigations in the eastern part of the German Bight from 1950-1974. Rapp. R.-V. Reun. Cons.'Int. Explor. Mer, 172: 432-444. 
$\boldsymbol{F}$

4

APPENDIX I

Fishes, Fish Assemblages, and Their Seasonal Movements

In the. Lower Bay of Fundy and Passa年aquoddy Bay, Canada

by

$-$
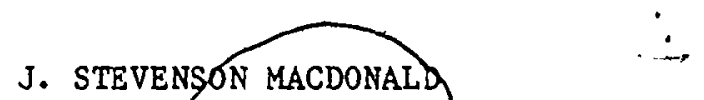

- Department of Zoology,

University "of Western Ontario,

London, Ontario, Canada

MICHAEL J. DADSHELL, RALPH G. APP, GARY D. MELVIN

Fisheries and Environmental Sciences

- Department of Fisheries and Oceans

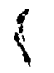

Biological Station

St. Andrews, New Brunswick EOG $2 \times 0$

and

DAVID METHVEN

The Huntsman Marine Laboratory

St. Andrews, New Brunswick EOG 2XO

96. 
Although the fish fauna of the Bay of Fundy-Gulf of Matne sistem is - , well documented (Bigelow and Schrqeder 1953; Richards 1963; Leim and Scott 1966), few studies have examfned long-term spatial and temporal changes and interrelationships of the fish assemblages. Previous studies in this region were concerned with the blology and seasonal movements of a single species (McKenzie and Tibbo 1961; McCracken 1963) or the occurrence and composition of communtities at a single site (Tyler 1971). "Moore (1977) and Quinn (1980) have emphasized the need for long-term research to establiṣh baseline information and estimates of natural variability for fisheries assessments and polflution impact studies. This is particularly true for inshore regions because of their importance as nurseries and feeding. grounds (Warfel and Merriman 1944; Rauck and 2ijlstra 1978). The increasing interest in food habits of fishes of an entire community is further reason to document movement, abundance, and co-extstence of fishes potentially utilizing the same food resource \&, (Richards 1963; Keast 1970; Tyler 1972; Steiner 1976; Hacunda 1979). This study examines spatial and temporal variation in fish diversity and abundance over a five year period at two offshore stations within Passamaquoddy. Bay, orie offshore, station in the Bay of Fundy, and at Inshore and beach stations in Passamaquoddy Bay. One of the offshore stations sampled had been sampled by Tyler (1971) in 1965-66. An effort. was made to determine whether changes have occurred over the intervening years. 
- Three offshore stations in the Bay of Fundy (B) and in Passamaquoddy Bay $(A, C)$ (Fig. 1) were sampled at approximately monthly intervals over a 5-yr period, 1976-81 (Table 1). Station $A$ was the same site sampled by Tyler (1971) during 1965-66. F1sh were collected using a 3/4-3.5 shrimp trawl (3.8- $\mathrm{cm}$ stretch mesh nylon; $15.5-\mathrm{m}$ foot rope) towed by the 150h.p., 14-m stern trawler, Fisheries and 0ceans R.V. PANDALUS II. Tows at each station were along a $1.6-\mathrm{km}$ transect at approximately $4 \mathrm{~km} / \mathrm{h}$. Sites $A$ and $B$ were sampled once per trip between $1976-79$ and site $C$ was sampled sporadically. From 1979-81 tows at A and B were replicated and site C was sampled regularly. Captured fishes were identifled as to species. Juveniles and adults were then counted separately. During the final year of collecting, fork length of ail fishes was recorded to the nearest centimetier and otoliths were collected from cod, ocean pout, plalce, winter flounder, and witch flounder for age determifation. Collections in the final year could not be made in December at site $A$.

Between June and September 1976, 12 estuarine, intertidal, and inshore marine stations were sampled within Passamaquoddy Bay and Head Harbour Passage ( $\dot{F} 1 g_{\text {. }} 1$ ). In addition, station 3 was sampled monthly during the period May 1976-November 1977, station 8 was sampled at approximately weekly intervals from May-September 1981, and stations 1 and 10 were sampled in December 1980 (Table 1). Fish were collected using a $9-\mathrm{m}, 1.3-\mathrm{cm}$ mesh beach seine,. a $3.7-\mathrm{m}$ shrimp trawl with a, 3 -mm codend towëd behind a 5-m Boston whaler, or bottom-set gillnets with stretched mesh sizes, ranging from $7.6-17.8 \mathrm{~cm}$. Standard fishing efforts employed with each gear type were: shore seine hauls of $5 \mathrm{~min}$ during the 
99

.0 
100 
101

TABLE I-1. Physical and chemical characteristics and sampling history of stations in the study area: Car: Si = shrimp . trawl; $S=$ seine; $G N=$ glint. Bottom type: $M=$ mud; $\mathrm{Sa}=$ sand; $\mathrm{Rk}=$ gravel or rock. 


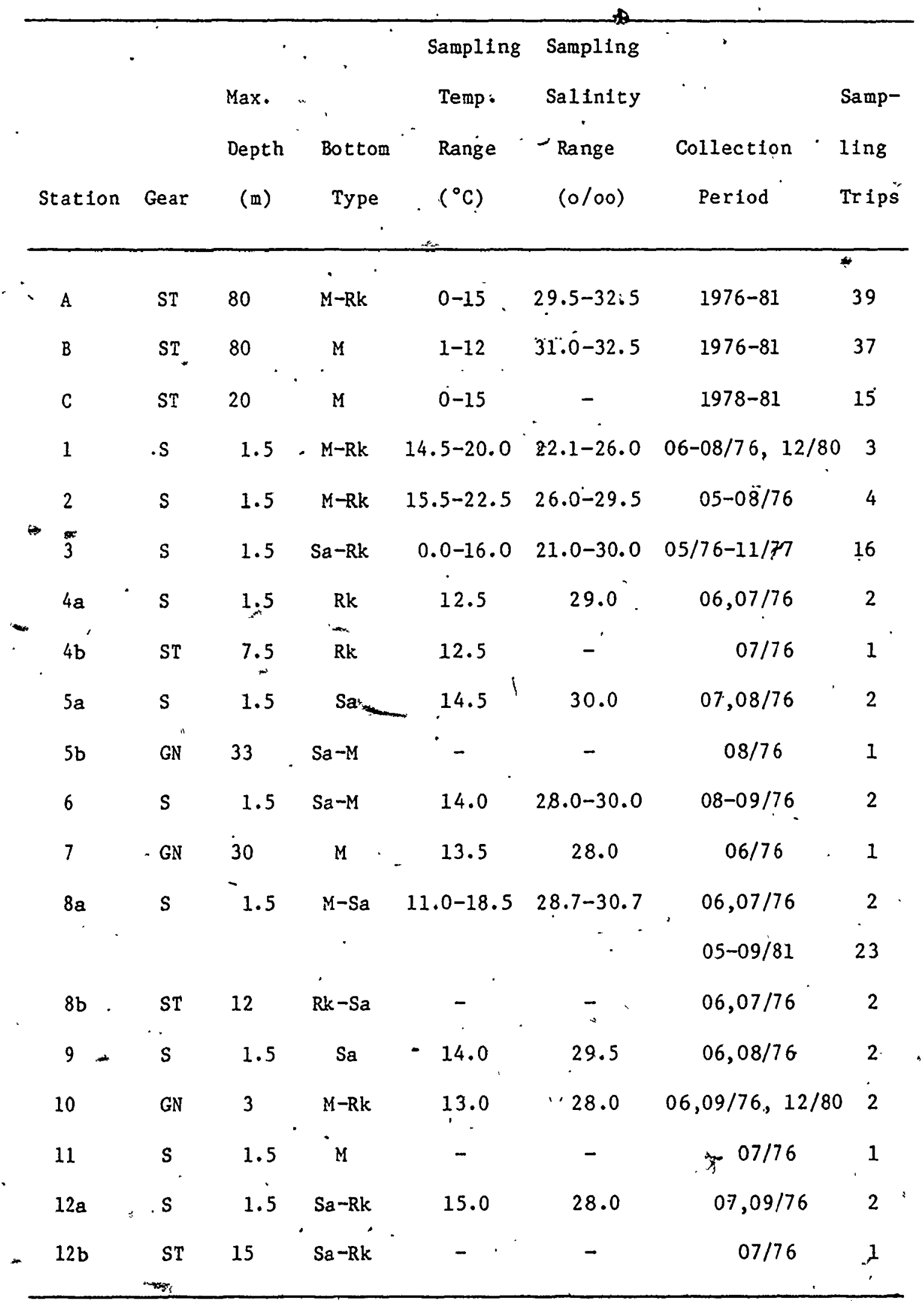




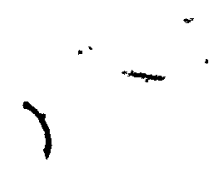

2-h period before and after low water; trawl tows of $10 \mathrm{~min}$; and overnight gilliet sets of $16-\mathrm{h}$.

Temperature, salinity, and substrate type were recorded for most sampling sites (Table 1 ). Temperature and salinity data inside and outside Passamaquoddy Bay came from routine monthly sampling by the Department of Fisheries and Oceans at a site opposite the Biological Station (near site A) and at "Prince 5" $2 \mathrm{mi}$ south of Bliss Island in the Bay of Fundy (near site B): Temperatures at deep stations were taken with a reversing thermometer attached to a Nansen bottle and at shallow stations with a hand thermometer. Salinities were determined with a laboratory salinometer from samples collected in the field. Substrate samples at deep stations were obtained with a PONAR grab: At shallow stations, substrate type was assessed visually.

Fishes were identified using Leim and Scott (1966) with the exception. of red and white hake, which were determined using Musick (1973).

\section{RESULTS AND DISCUSSION}

Station Environmental Characteristics.

- Temperature and salinity at stations $A$ and $B$ followed the typical yearly cycle of a cold temperate sea (Fig. 2). Annual temperature range In the Bay of Fundy was less than In Passamaquoddy Bay. Summer temperatures at Inshore sites were similar to the deep sites but were higher at eștuary stations (1e. I and 2) (Table 1). Three notable variations occurred: the early months of 1977 and August 1978 were 


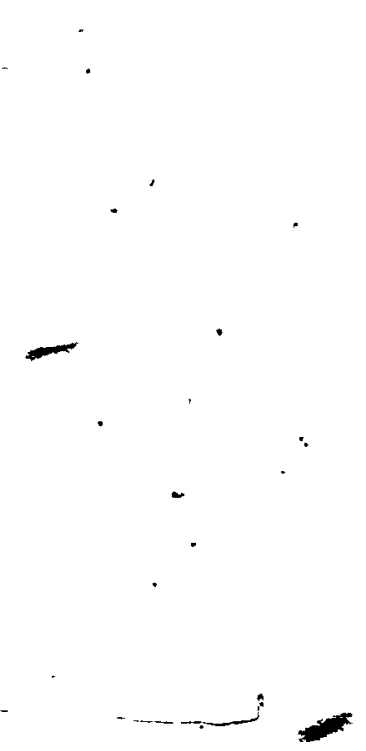

(3)

1

FIGURE I -.2. Temperature and salinity at station $B$ in the Bay of Fundy and station A in Passamaquoddy Bay during 1976-1981."

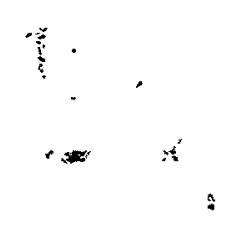

w
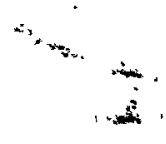

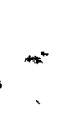


Temperature ("C)

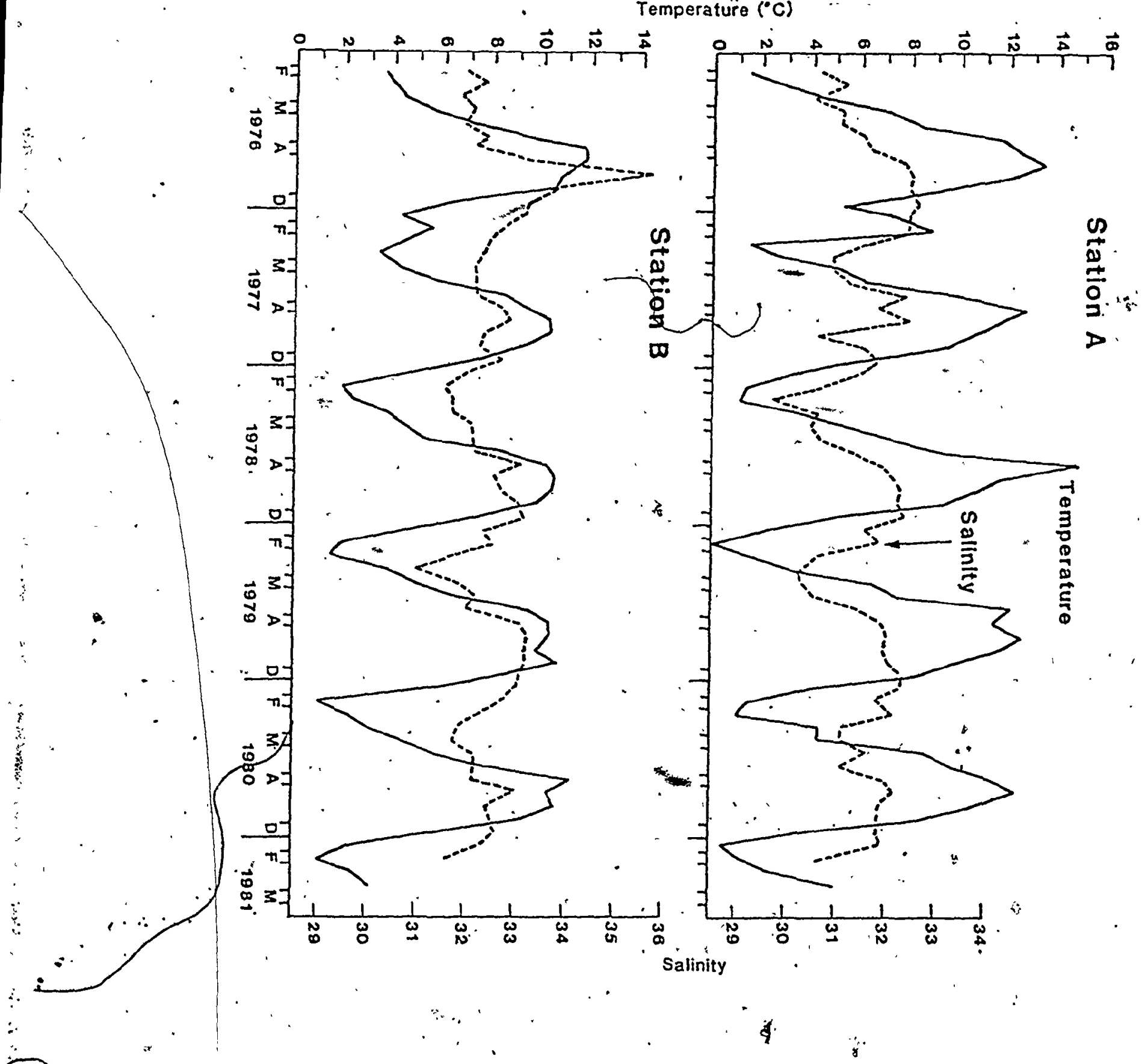


abnormally warm, particularly at station A (J. Hull, pers. comm.); at station B, temperatures increased and decreased earlier than usual during 1980; and throughout the study period there was a generalized cooling trend.

Salinities were'highest in late summer-early fall and lowest in early spring at both sites but highest in winter in the-Bay of Fundy (B) (F1g. 2). - Inshore sites had salinities of 1-2 p.pt less than station $B$ and salinities in estuarine sites were as low as 22 ppto during summer (Table 1).

The substrate at stations $B$ and $C$ was mud and at station $A$ mixed mud, gravel, and rock (Table 1). Station A had the steepest slope, approximately $20 \mathrm{~m} / \mathrm{km}$. Slopes at jations $B$ and $C$ were $4 \mathrm{~m} / \mathrm{km}$ and 6 $\mathrm{m} / \mathrm{km}$, respectively. Substrate types at coastal intertidal sites were mixed sandy mud andorock. Slopes were gradual, about 1:100 m. Gillnet collections at stations 5 and 7 were $30-33 \mathrm{~m}$ in depth with mud bottom. Estuarine stations (1, 2 and 10$)$ had extremely soft mud bottoms and. station 2 had extensive eel grass beds.

Fishès-and Seasonal Occurrence

S1xty-two spectes of fish were captured during the study period (Tables 2 and 3). Residency perlod and abundance are Indicated. F1sh occurrence is expressed as part of the summer component (July-actober), the winter component (November-June), the regular, component (caught year roụndx, or the occasional component. Fishes that were occastonal components show no seasonal abundance pattern and were collected less than 70 times at stations $A, B$ and $C$ or 1 ess than 15 fimes at stations 
1.07

$$
\hat{.}
$$

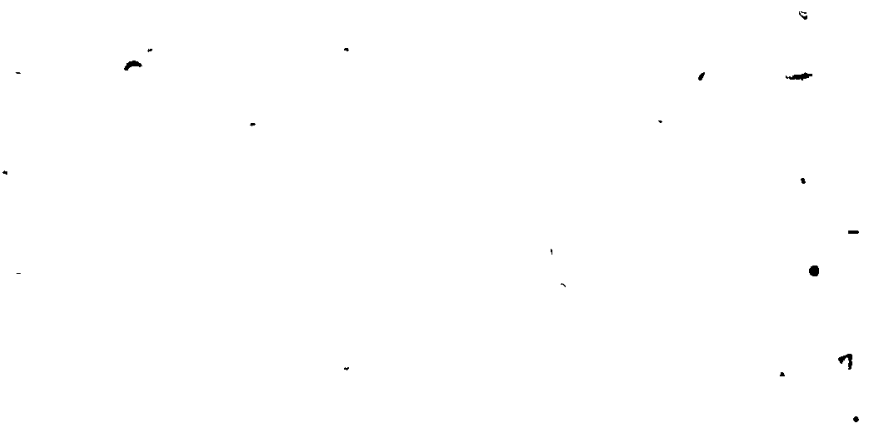

$\div$

TABLE I - 2. Residency and abundance of fishes occurring at deep sampling stations in the Bay of Fundy and Passamaquoddy Bay. Residency is: R (regular; S (summer); W (wintér); 0 (occasional); N (never encồuntered). Abundance is: a (abundant); $\quad c$ (common); $r$ (rare). 1

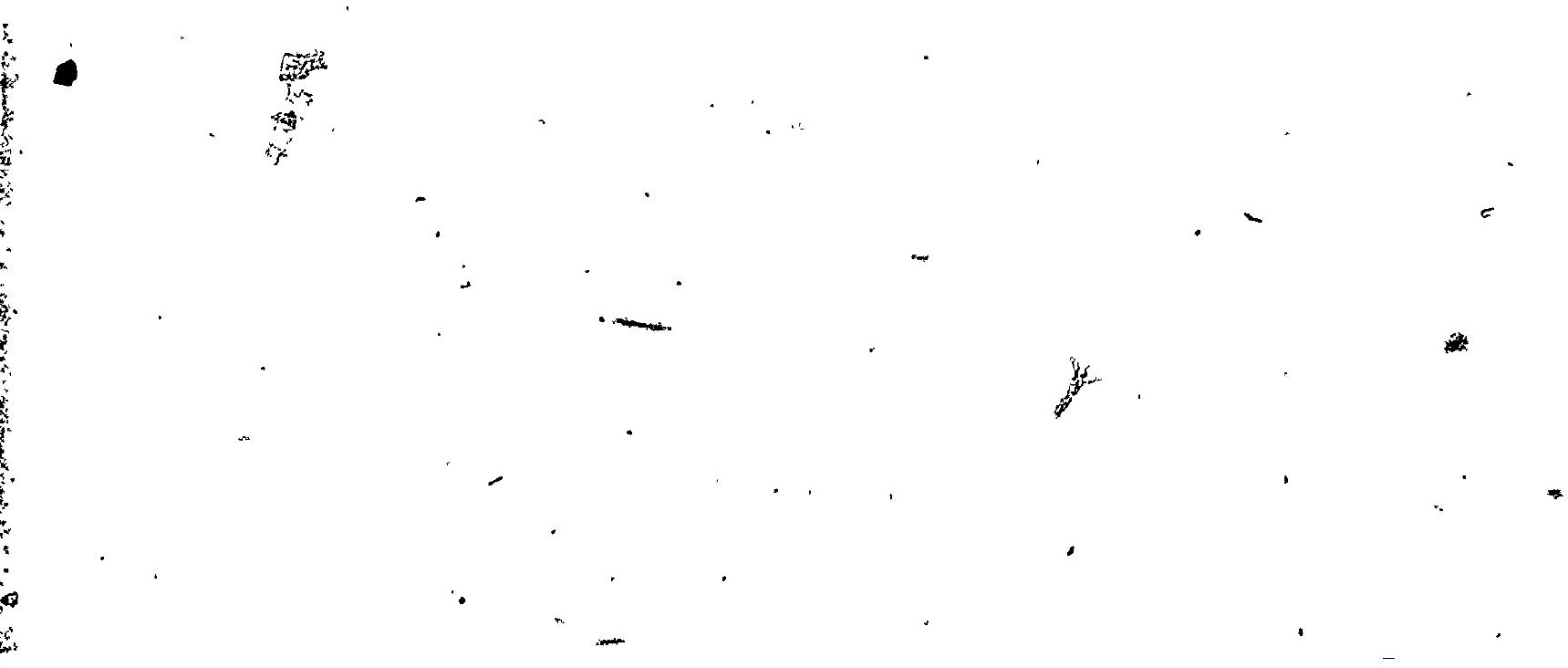


TABLE I - 2.

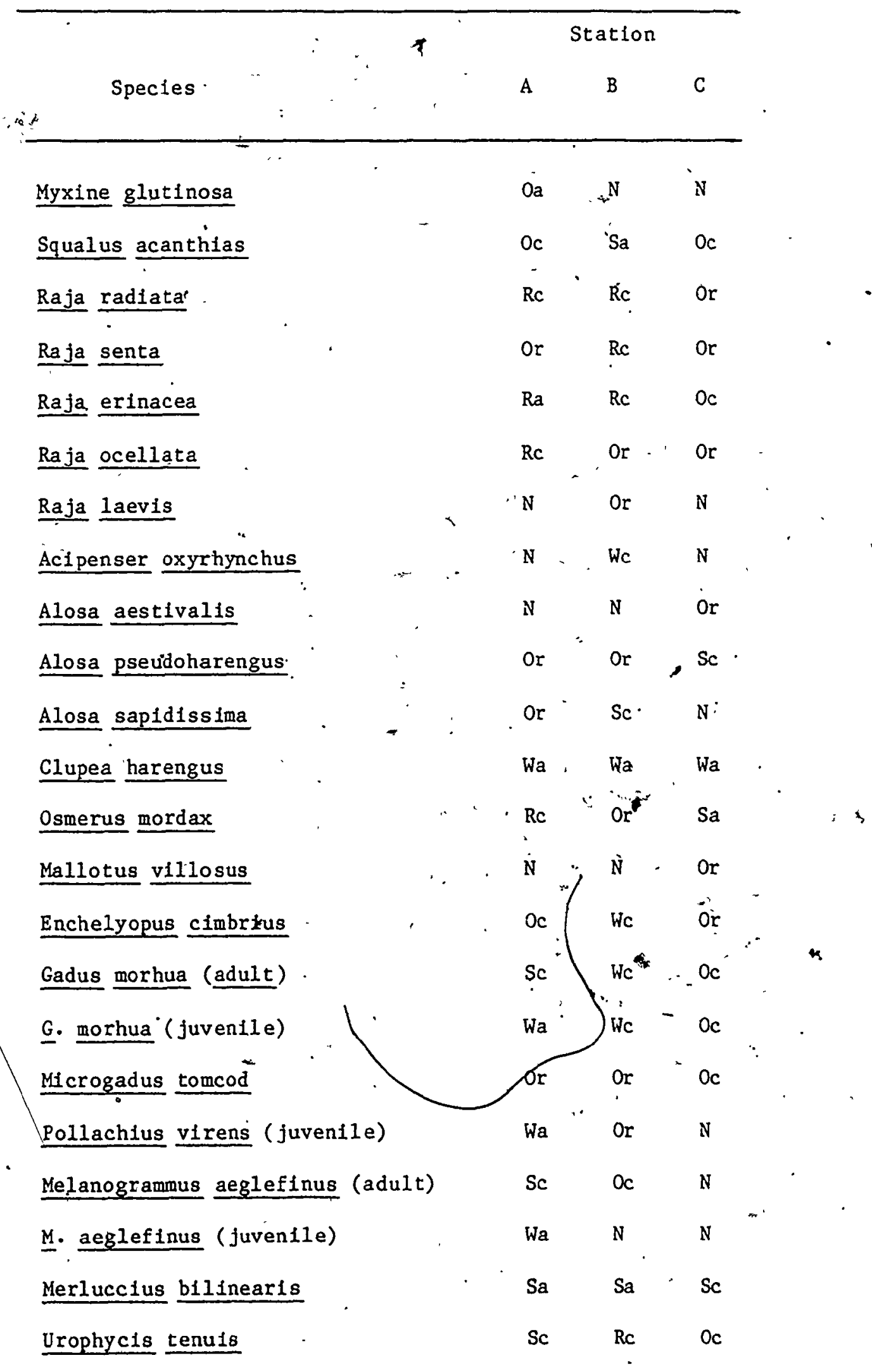


TABLE I - 2. (Cont'd.)

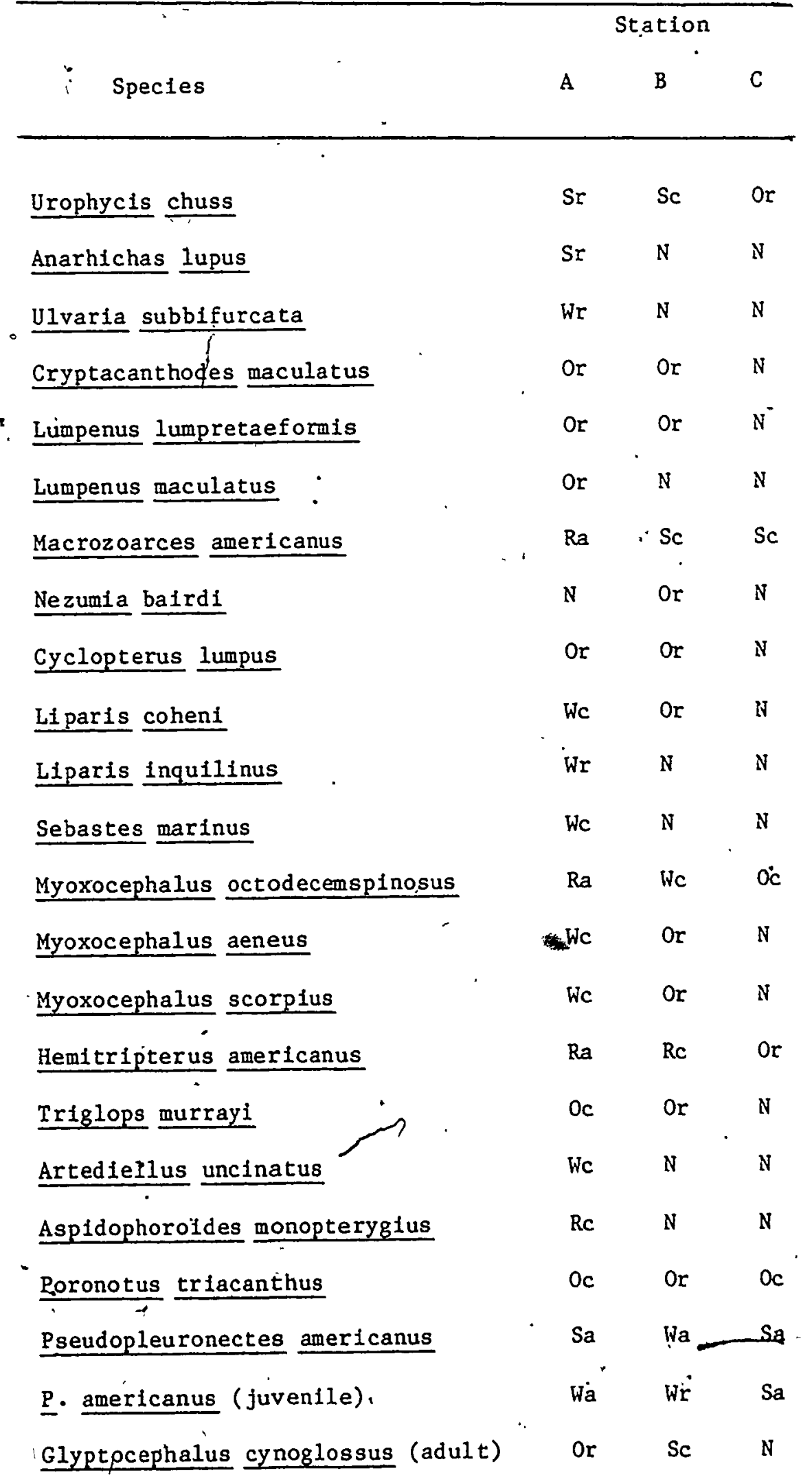




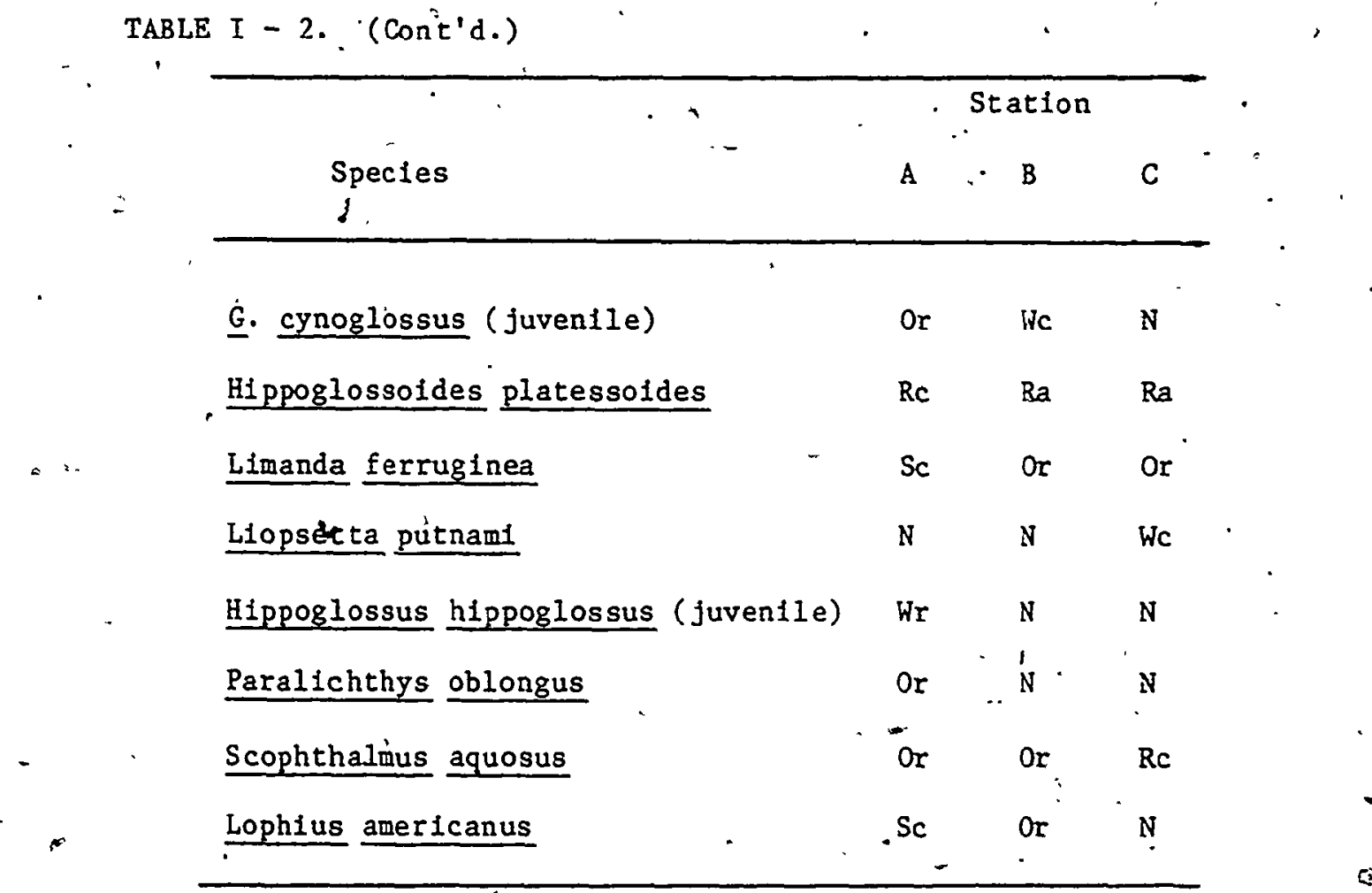

110 
111

TABLE I - 3. Residency and abundance of fishes-occurring at estuarine, Intertidal, and shallow marine sites in Passamaquoddy 'Bay. Residency is: $R$ (regular); S (summer); $-\mathrm{W}$ (winter); 0 (occasional). N (never encountered) is used to describe residency at station 3 only because this is the only shallow site that was sampled year round. Abundance is: a (abundant); c (common); r (rare). 
TABLE I - 3.

\section{Station.}

Spectes $\quad \begin{array}{llllllllllll}1 & 2 & 3 & 4 & 5 & 6^{*} & 7 & 8 & 9 & 10 & 11 & 12\end{array}$

Squalus acanthias

Raja radiata (juvenile)

$\underline{\text { Raja erinacea }}$

$\underline{\text { Raja ocellata }}$

Alosa aestivalis

Alosa pseudoharengus

$$
-\quad-\mathrm{Sr}-\mathrm{Or}-\mathrm{Sa}-\mathrm{Sa}
$$

Clupea harengus

$$
\text { sc or or or - or or Sa - Sa or - }
$$

Salmo salar

Osmerus mordax

or se Wa - $-j-$ or Sa - or

Malloitus villosus

Fundulus heteroclitus

Sà Sc Wc -

Gasterosteus aculeatus

Sc Sa oc or or or - Sc - Sc or or

Gasterosteus wheatlandi

Apeltes quadracus

Oc Sa Sr $-\quad-\quad-\mathrm{Sr}_{-} \mathrm{Sr}$

Pungtitus pungttius

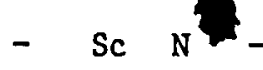

Anguilla rostrata

Enchelyopus cimbrius

(1 arvae)

Gadus morhua (adu1t)

G. morhua (Júvenile)

Microgadus tomcod

$$
\text { - Sa. N }
$$

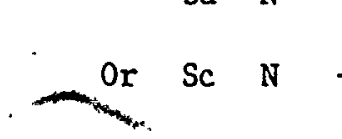

Pollachlus virens

(juventle)

or or sa or or or - sa or,,+ or 
0

- TABLE I - 3. (Cont'd.)

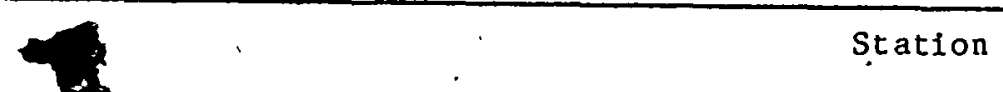

$\begin{array}{lllllllllllll}\text { Species } & 1 & 2 & 3 & 4 & 5 & 6 & 7 & 8 & 9 & 10 & 11 & 12\end{array}$

\section{Urophgcis tenuis}

(juvenile)

Ammodytes americanus

Scomber scombrus

Scomber scombrus

Pholis gunnellus

Ulvarla: subbifurcata

Cyclopterus lumpus

(juven1le)

Macrozoarces americanus

Myoxocephalus

octodecems pinosus

Myoxocephalus aeneus

Myoxocephalus scorpius

Hèmitripterus americanus

Menidia menidia

Pseudopleuronectes.

americanus (adult)

$0 r-S r \quad O r \quad S a$

P. americanus (juvenile)

Liopsetta putnami

$-\quad=\mathrm{Sr}-\mathrm{Or}$ or

$\mathrm{Sr}-\mathrm{Or}$ or $\mathrm{Or}$

Syngnathus fuscus

$\mathrm{Sc}^{\circ}$ Or Sr

Or Sc N 
1-12 during the entire study. We realize that some fish at all sites may have been missed entirely or are listed as rare simply because they were unavallable to the sampling gear used or could avold capture (eg. mackerel).

h

The eight species of flatfishes captured (Table 2) represent the most diverse and abundant group of demersal fishes present: Pseudopleuronectes americanus, the winter flounder, was the numerically dominant species (Figr $3 ; 5)$. Juvenlles ( $22 \mathrm{~cm}, 2+$ age group; Fig. 6) were abundant in shallow water during summer (Fig. 5) and at deep stations over hard bottom in Passamaquoddy Bay during winter (Fig. 3). Adult winter flounder were abundant in Passamaquoddy Bay, both Inshore and offshore during summer, but rare at the Bay of Fundy site (Fig. 3). During winter they were rare or absent inside Passamaquoddy, Bay but common to abundant at the Bay of Fundy station. This pattern reflects. the winter movement of this species into deeper water in the northern pärt of its range (Sa1la 1961; McCracken 1963; Van Guelpen and Davis 1979), which is probably triggered by temperature. Adults were seldom present in Passamaquoddy Bay when temperatures were below $6^{\circ} \mathrm{C}$. During the wam fall of 1977 adult flounder were abundant until late December in Passamaquoddy Bay. 'During "norgâgle" years adults left Passamaquoddy by late November (Fig. 3). McCracken (1963) found a similar relationship between minimum flounder catch-per-effort and minimum temperature. Surges of adult flounder abundance at offshore sites which coincided with rapid temperature change in spring and fall were evident in most years (Fig. 3 and see Tyler 1971). This is probably related to rapid onthore or offshore movement of the population. 


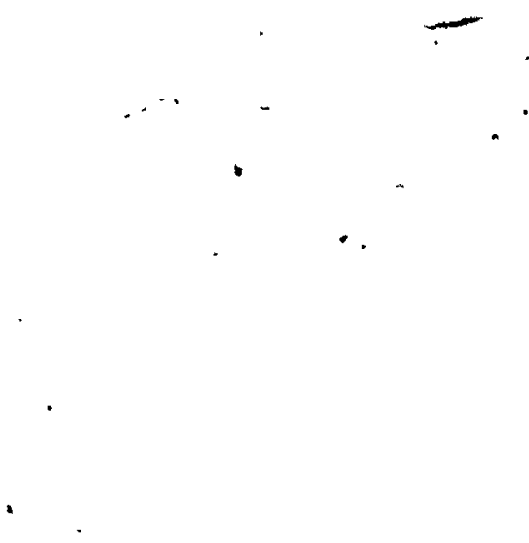

FIGURE I - 3. Seasonal occurrence and abundance of juvenile and adult

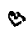

- flatfishes, at deep stations in the Bay of Fundy and Passamaquoddy Bay. For witch flounder (Giyptocephalus cynoglossus), dark bars are aduits and lined bars are juventles at site $B$. Witch flounder were not found at site at site A. For plaice (Hippoglossoides platessoides) open bars are site $B$ and lined bars are site C (a.11 juveniles). Plaice occurred less often at site A. 
Abundance Per Tow

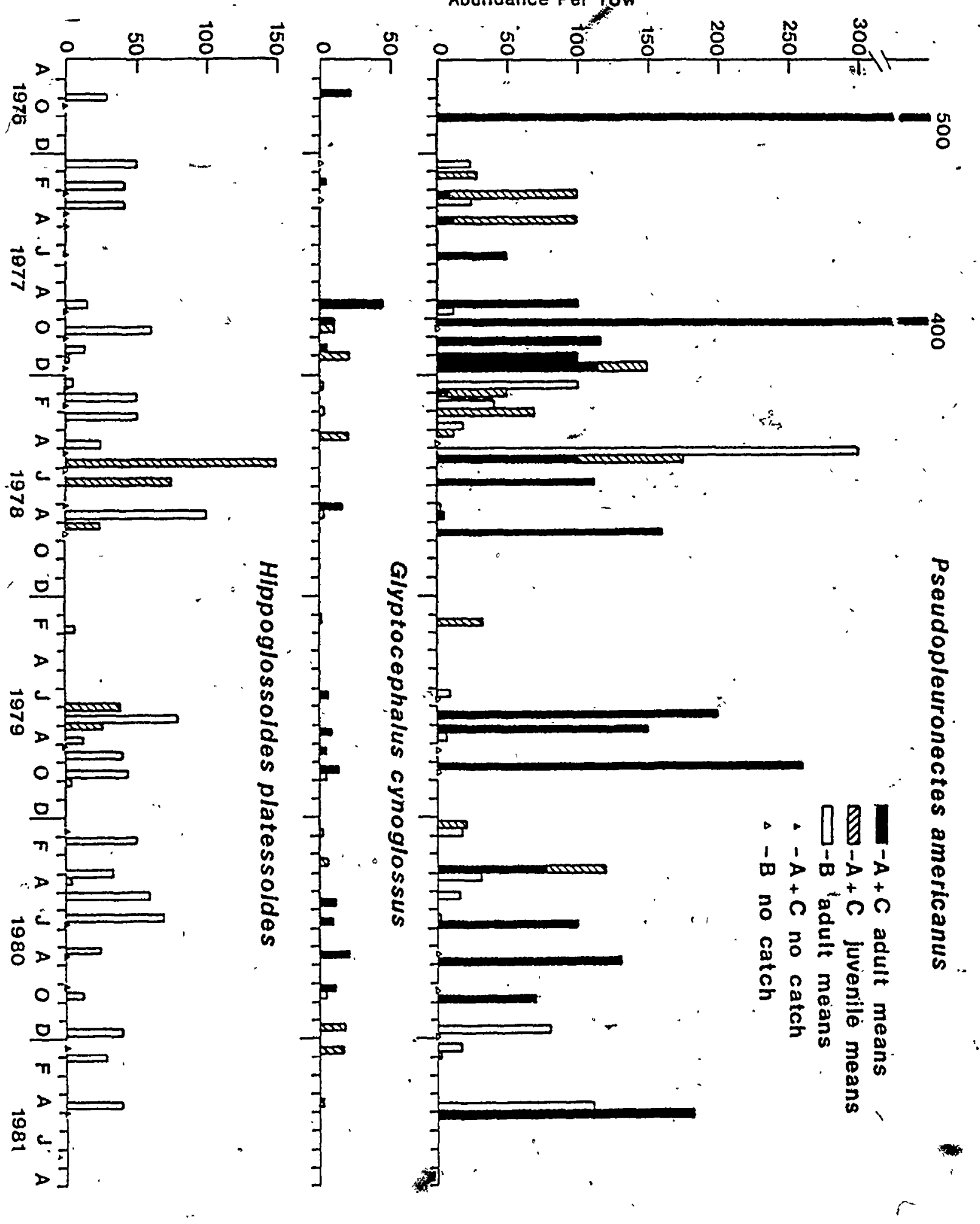




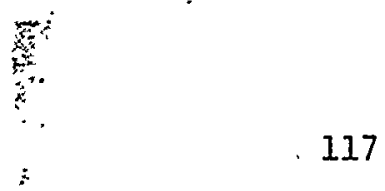

3

$\vdots$ 
Abundance Pör Sampling Trip
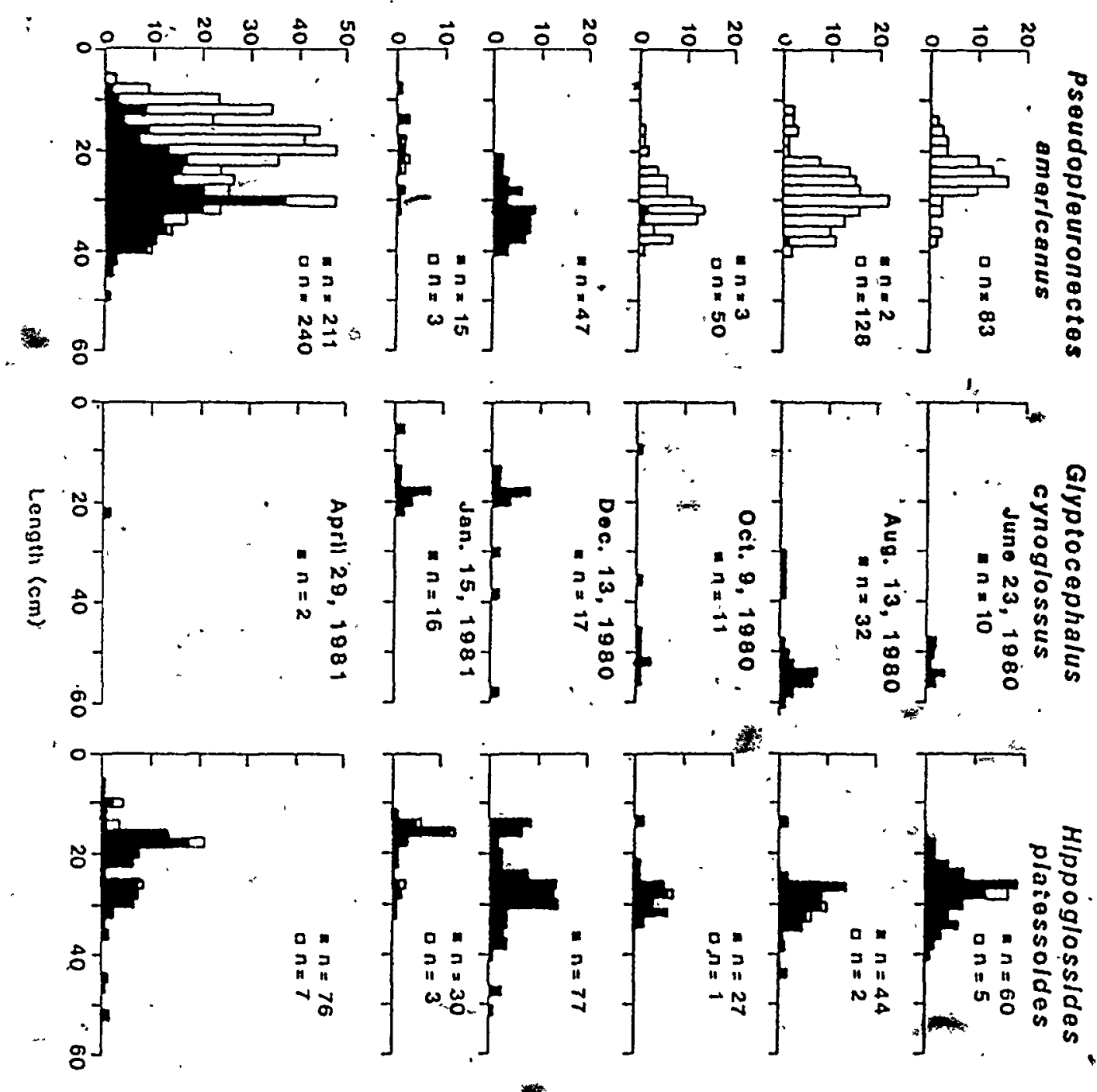
119

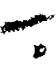

FIGURE I - 5: Seasonal occurrence and abundance of fishes captured by seine, at Intertidal site 8 from May to September 1981.

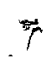



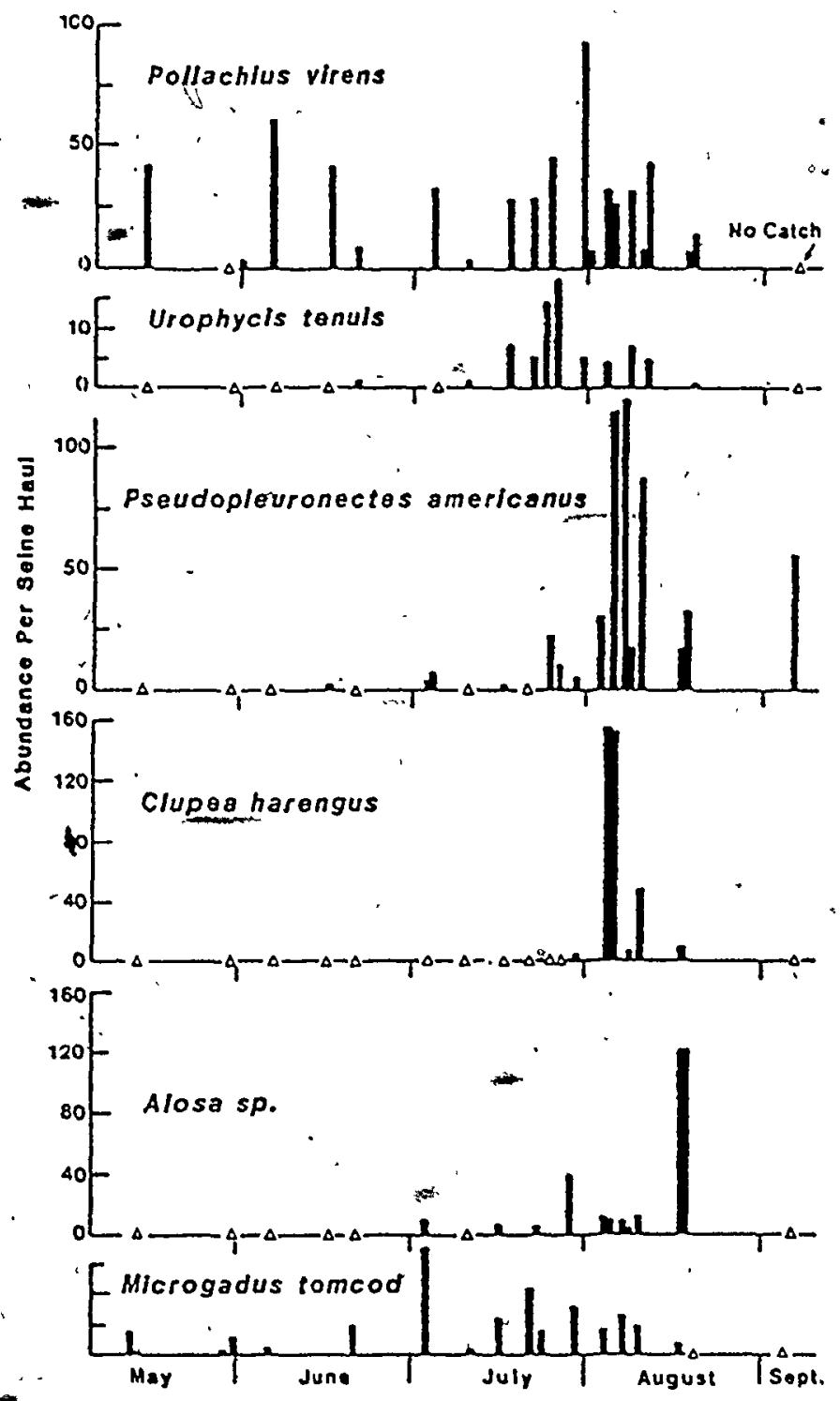

$\because$

. 


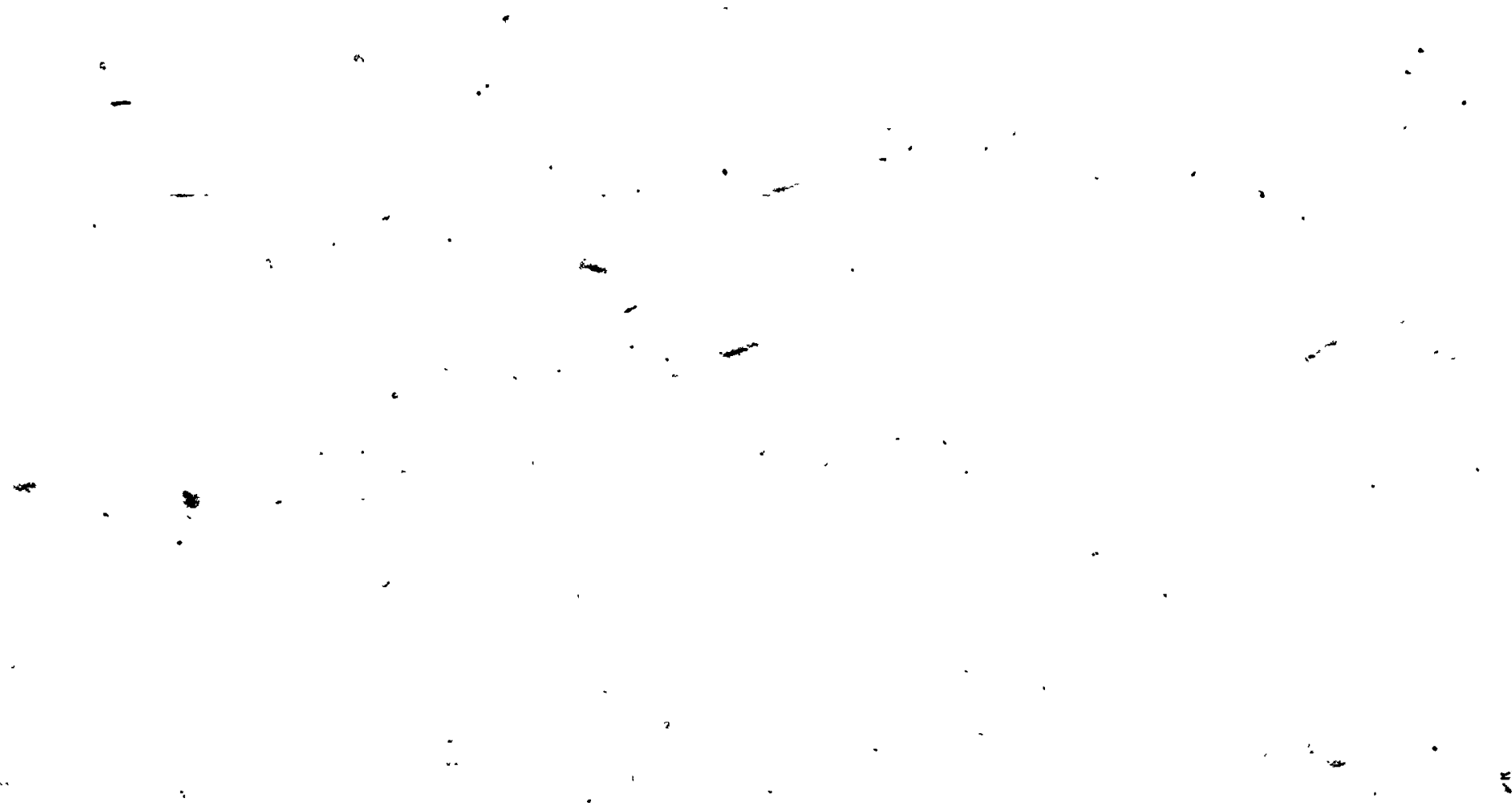

FIGURE I - 6 Mean fish length versus age for five fish species caught at sites $A$ and $B$; December 1980 - June 1981 . 
$\therefore$

$+$

- 122

$\rightarrow$

1

$-$

Glyptocephalus cynoglossus
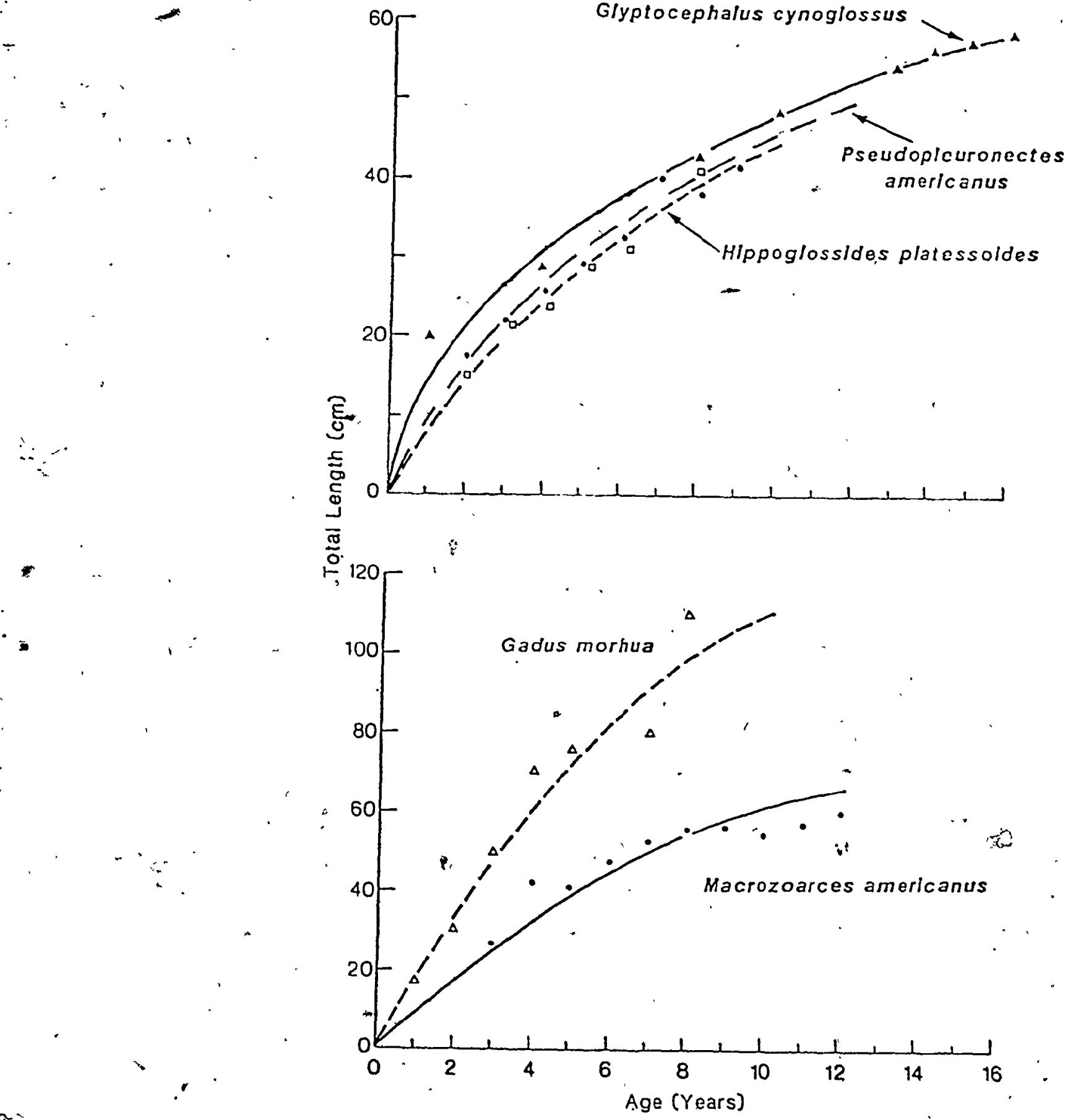

13.

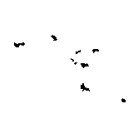


The witch flounder, Glyptocephalus cynoglossus, was rare or absent at all times inside Passamaquoddy Bay but was a regular component at the soft-bottom Fundy station. Catches from June to October consisted of large adult witch $(30-60 \mathrm{~cm}, 6+$ age group) but catches from November to May were 6-25 cm juveniles $(0-6 \mathrm{yr}$ ) (F1g, 4, 6). Adult witch on the Scotian Shelf also move from intermediate depths (100 m) in sumer to deeper water in winter (Powles and Kohler 1970). However, there is no previous record of the abundance of juvenile witch on softibottom or of their replacement of adults during winter.

Juvenile plaice (Hippoglossoides platessoldes) were a major summer component of station $\mathrm{C}$ and a regular component of the Fundy station, both soft-bottom habitats, but was only occasiorlal at the hard-bottom station (A). "Age 2 plaice $(6-14 \mathrm{~cm}$; Fig; 6) were first captured with our shrimp net tn April. By the following year recruitment to the gear appears complete at an average size for the age-class of $17 \mathrm{~cm}$ (Fig. 4). Juvenile plaice are sedentary, soft-bottom dwellers, that exhibit little. seasonal movement, and migration from nursery ground to adùlt stock is diffusive (Bigelow and Schroeder 1953; Leim and Scott 1966). However, some seasonal movement does occur when plaice leave soft-bottom, middepth habitat $(30 \mathrm{~m})$ for winter and return in summer (present study). Plaice were a regular, low-denstey component at station A in 1965 (Tyler 1971). but we found they were almost absent between 1976-81. The difference may be attributable to the general decline of groundfish abundance in the Bay of Fundy after 1970 (Hare 1977).

Among other flatflshes, window-pane, Scophthalmus aquosus, was a regular component at station $C$ and the smooth flounder, Liopsetta putnami, was common among the inshore-estuarine communities during summer 
(Table 2, 3). Yellowtail flounder (Limanda ferruginea) was a regular, low-abundant member $(4-5 /$ tow) of the summer assemblage at station $A$ and an occastonal' at the other two deep stations. Juvenile hallbut (Hippoglossus hippoglossus.) was regular, lowrabundance member $\left(2-3 /\right.$ tow $^{\circ}$ of the winter assemblage at station A. The four-spot flounder (Paralichthys oblongus) was captured $\underset{0}{\text { once }}$ at station-A during the abnormally, warm fall of 1978 .

Seven specles of gadoid fishes were captured during the study (Table 2, 3). Unlike the flatfishes, juve Hes of all species except stlver. hake were found at shallow inshore stations during some period of the year.

Adult cod (Gadus morhua) were an abundant nember of the summer component at offshore sites in Passamaquoddy Bay, particularly station A, but were absent in winter and a common nember of the early winter assemblage in the Bay of Fundy but rare thereafter (Fig. 7, 8). During summer juvenile cod $(10-20 \mathrm{~cm})$ were captured occasionally during seining of beach sités but were more common in gillnet catches at intermediate depth $(30 \mathrm{~m})$ Inshore (stations 5 and 7 ; Table 3 ). The shallow water abundance maxima of young $\operatorname{cod}(0+, 1+; 17 \mathrm{~cm}$ ) has not been previously documented in the western North Atlantic but is a well known situation for cod in the North Sea (Daan 1978). During winter juventle cod were abundant at station $A$ or in colder winters at station B (Fig. 8, 198081). Both juvenile and. adult cod were more abundant at station $A$ during our study than during 1965..(20-70/tow, Tyler. (1971); 1976-81, 50400/.tow).

Haddock (Melanogrammus aegleftnus) were never abundant during our. study. Adults were captured only at the hard-bottom station A during 
$125^{\circ}$

1.

5

$a$

as:

$\rightarrow \quad-$

FIGURE I - 7. Seasonal occurrence and abundance of gadoids at deep stations in the Bay oof Fundy -and Passamaquoddy Bay.

o

$\theta$

$\rightarrow$ 


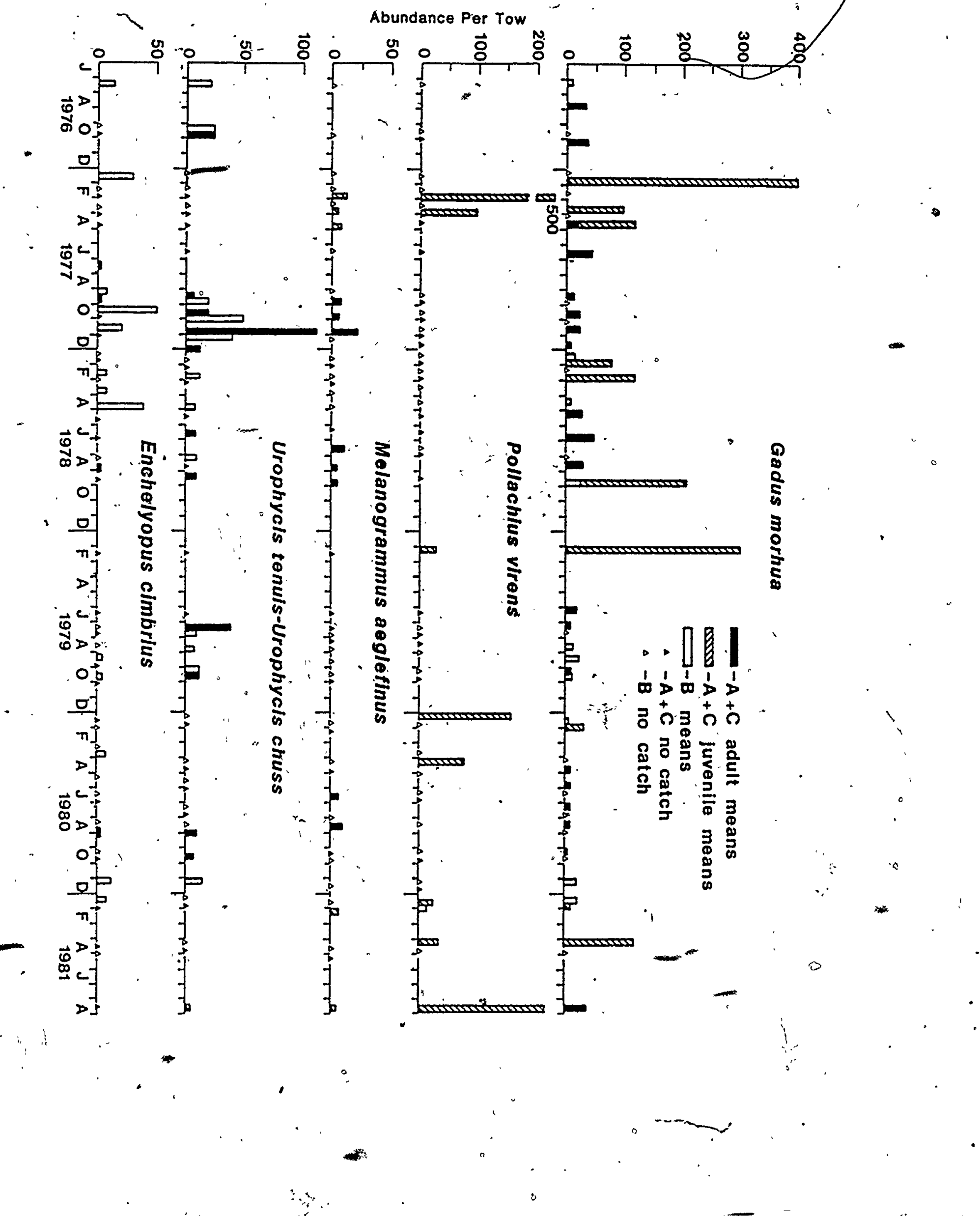


$=127$

. 


\section{Gadus morhua}

- June 23, 1980
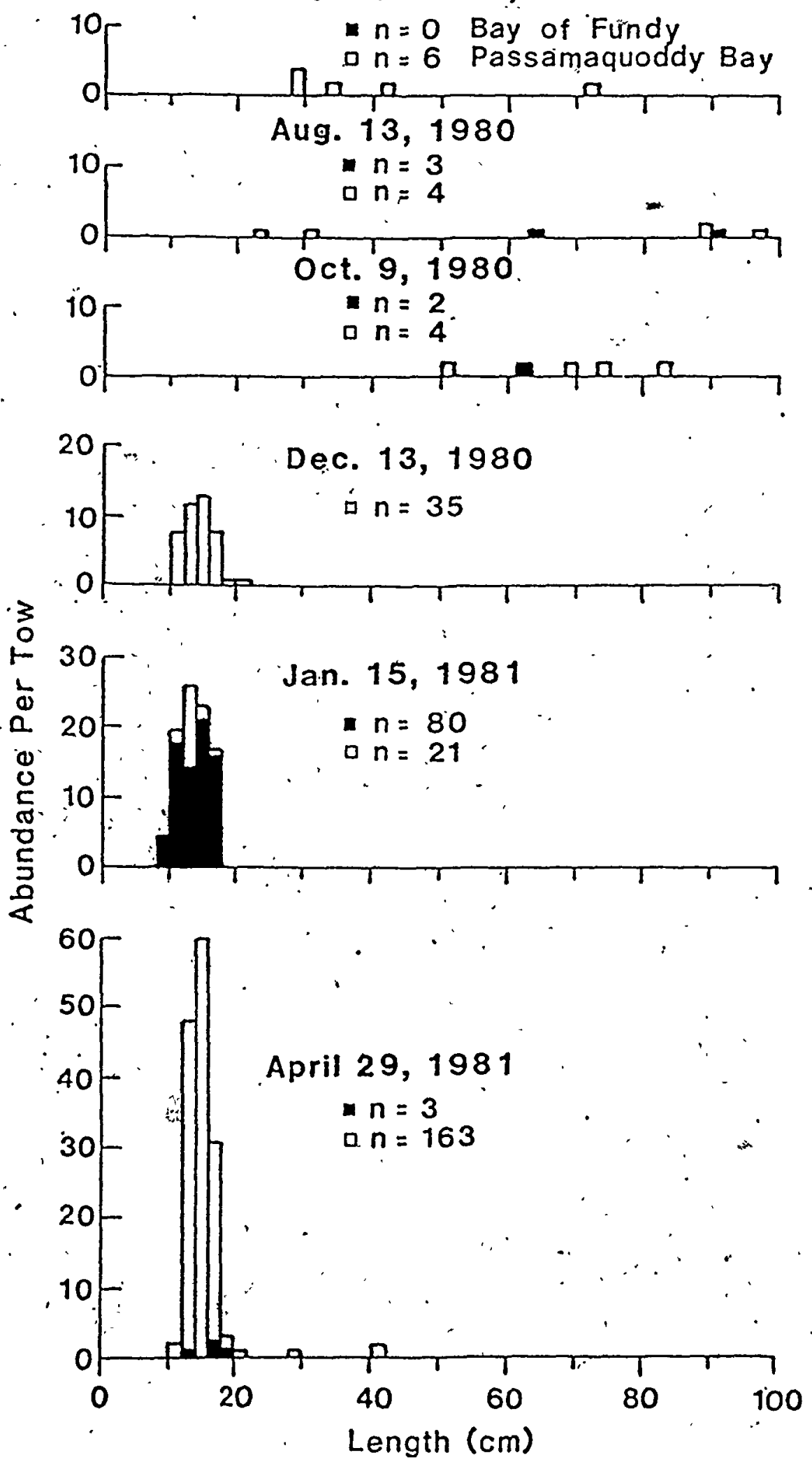
summer (F1g. 7) and juvenile haddock were occasionally captured at the same site in winter. Catches of haddock declined from a maximum of $25 /$ tow to less than $5 /$ tow during the study pertod (Fig. 7). However, up to 260 haddock/tow were caught at site A during 1965 (Tyler 1971). Decline in abundance after 1965 might be due to the collapse of the Bay of Fundy haddock stock 1970 (Hare 1977).

Only juventle pollock (Pollachius virens) were captured during the study. Pollock of the annual year-class. $(0+)$ were either rare or extremely abundant at beach' sites $(100+/$ seine haul) in a given year, depending, perhaps, on the overall size of the annul year-class. Pollock dominated beach catches during early summer but disappeared from this region by September: (Fig. 5). Pollock of the same year-class were abundant at site A in Passamaquoddy Bay during winter (Fig. 7). In years when $0+$ pollock were abundant along the beach in summer they were also abundant the following winter at site $A(1976-77)$ and, in summers of low abundance on the beach, they were correspondingly rare offshore in winter (1977-78; Fig. 7). Larger than usual numbers of pollock larvae were present in the plankton March 1979 (Scott 1980) and we again encountered large numbers of $0+$ juveniles at site $A$ in the winter of 1979-80. Present findings suggest therefore probably three large year-ciasses produced during our study period, 1976,1979 , and 1981 in contrast to one large year-class of 1979 reported by Scott (1980).

Adult white and red hake (Urophycis tenuis, U. chuss) were a common.

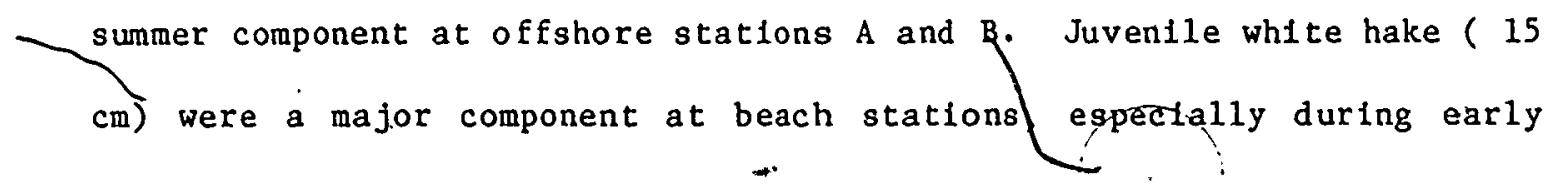
summer (Fig. 5), but were rarely captured at offshore sites in winter. Also in 1965 few small hake were captured after December (Tyler ig71). 
Apparently hake leave Passamaquoddy Bay in winter. The only time hake were obsorved during winter was at station B in the Bay of Fundy during the abnormally, warm winter of 1977-78 (Fig. 7):

The fourbeard rockling (Enchelyopus cimbrius) was present in the winter component at station B in the Bay of Fundy and as a periodic in summer at station A (Fig. .7). The mesh size of our gear was just small enough to capture large individuals of this species and it was probably more abundant than indicated. Larval rockling were a rare but regular component of inshore sites during summer (Table ${ }_{4}^{4}$ ). Battle (1930) and Tyler (1971) both consldered rockling a summer periodic in Passamaquoddy Bay occurring there during spawning migration. Tỳler's catch rate at station A (2-3/tow) was similar to ours at that site. Catch rate at station B (10-50/tow), indicates rockling may concentrate at offshore sites in winter.

Silver hake (Merluccius bilinearis) was often the most abundant gadoid found at offshore stations during summer and juveniles were a regular component at station B year round (Fig. 9). Adult silver hake were present in company with other migratory summer periodics, including shad (Alosa sapidissima), dogfish (Squalus acanthias), and butterfish (Poronotus triacanthus).

The tomcod (Microgadus tomcod) was a regular component of the inshore assemblage and was particularly abundant at beach sites during early summer (Flg. 5) and in estuaries in early winter (Table 3).

Clupeolds and osmerids (Table 2) made up amajor portion of the fishes caught at inshore sites. At beach station 8, alewife (Alosa... pseudoharengus), herring (Clupea harengus), and smelt (Osmerus mordax) appeared in mid-July and increased in abundance during August, largely 

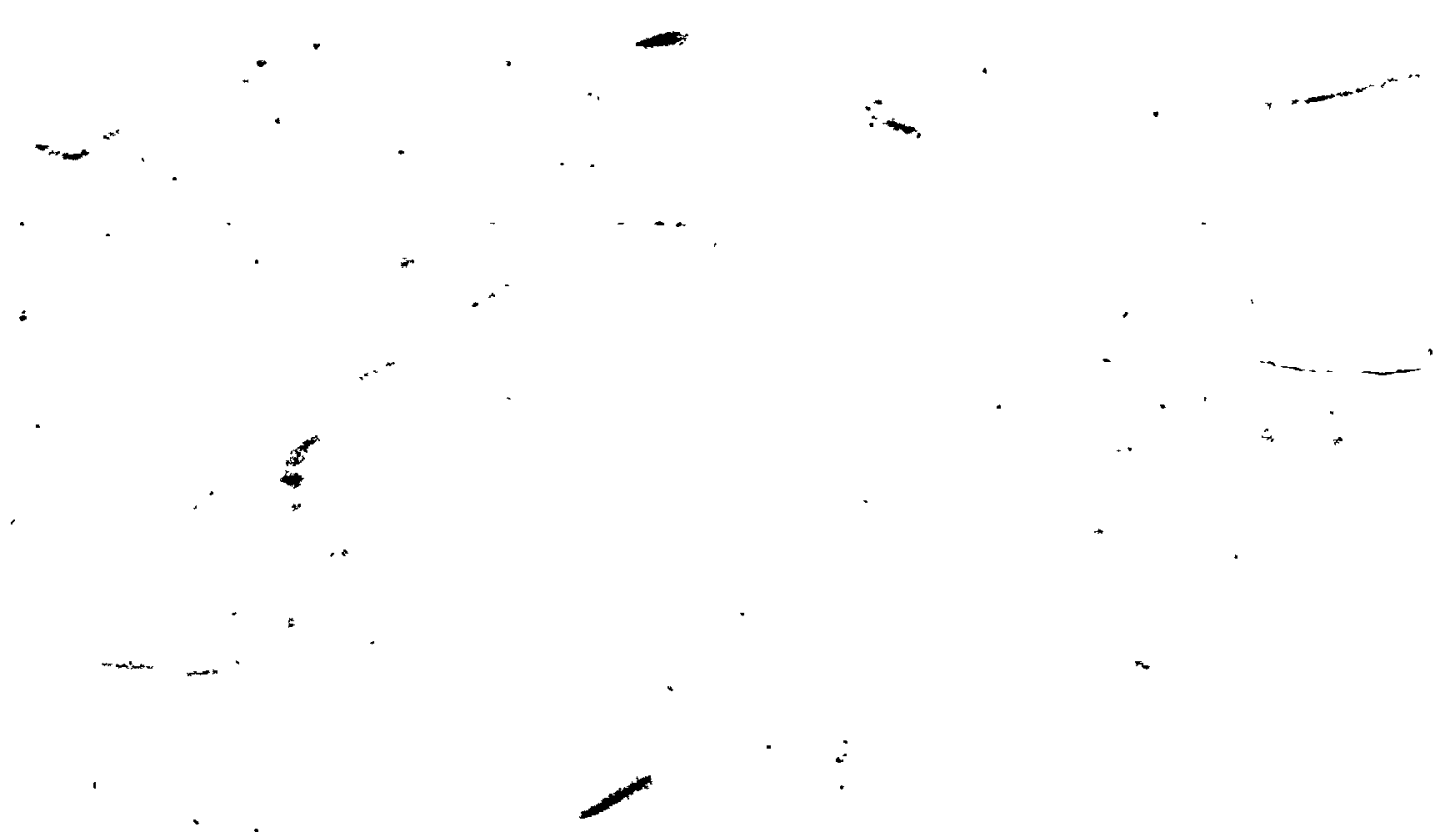

- TABLE I - 4.' Catch of fishes at intertidal seining site 3 (Brandy Cove) during period May 1976-Novèmber 1977. Fish captured during thrêe $5-\mathrm{min}$ seine hauls $(100 \mathrm{~m} \cdot \mathrm{x} 15 \mathrm{~m})$ $([j]=\text { juventle; }[1]=\text { larvae })^{\circ}$
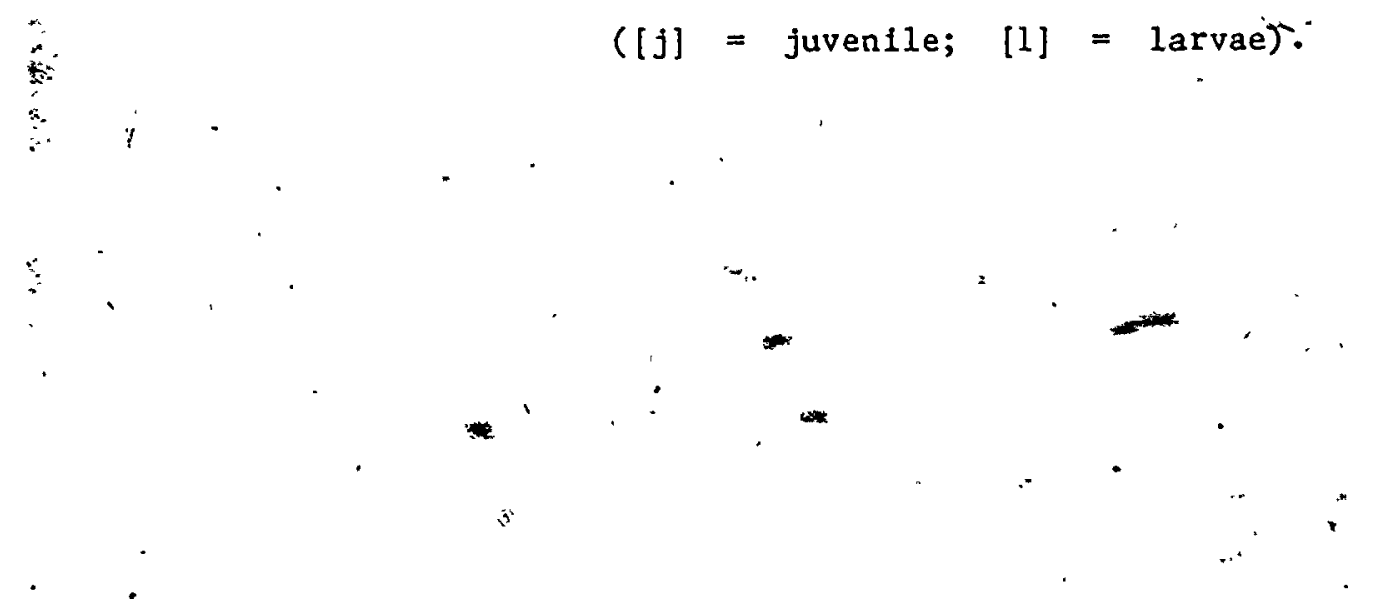

י. 


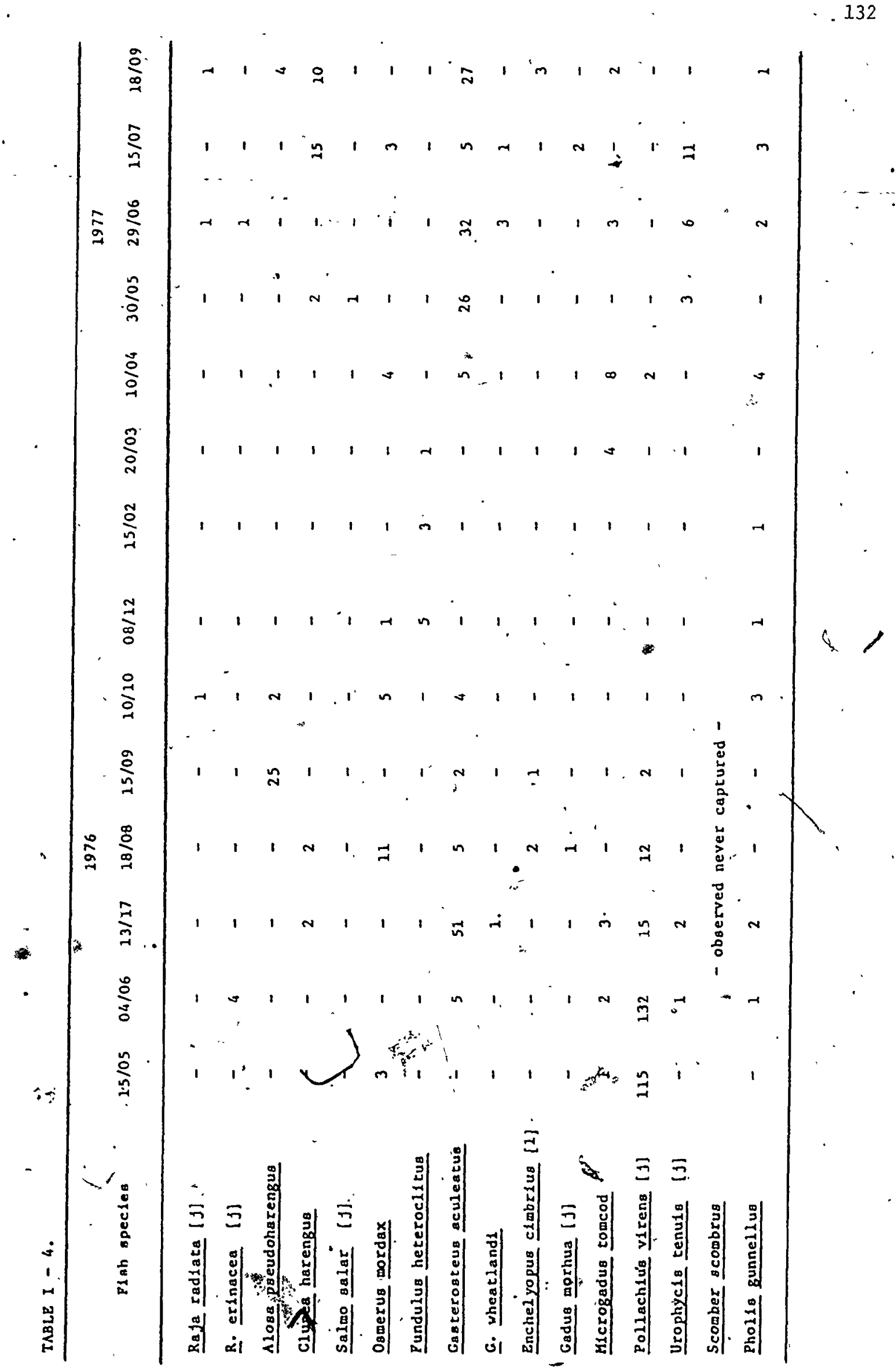




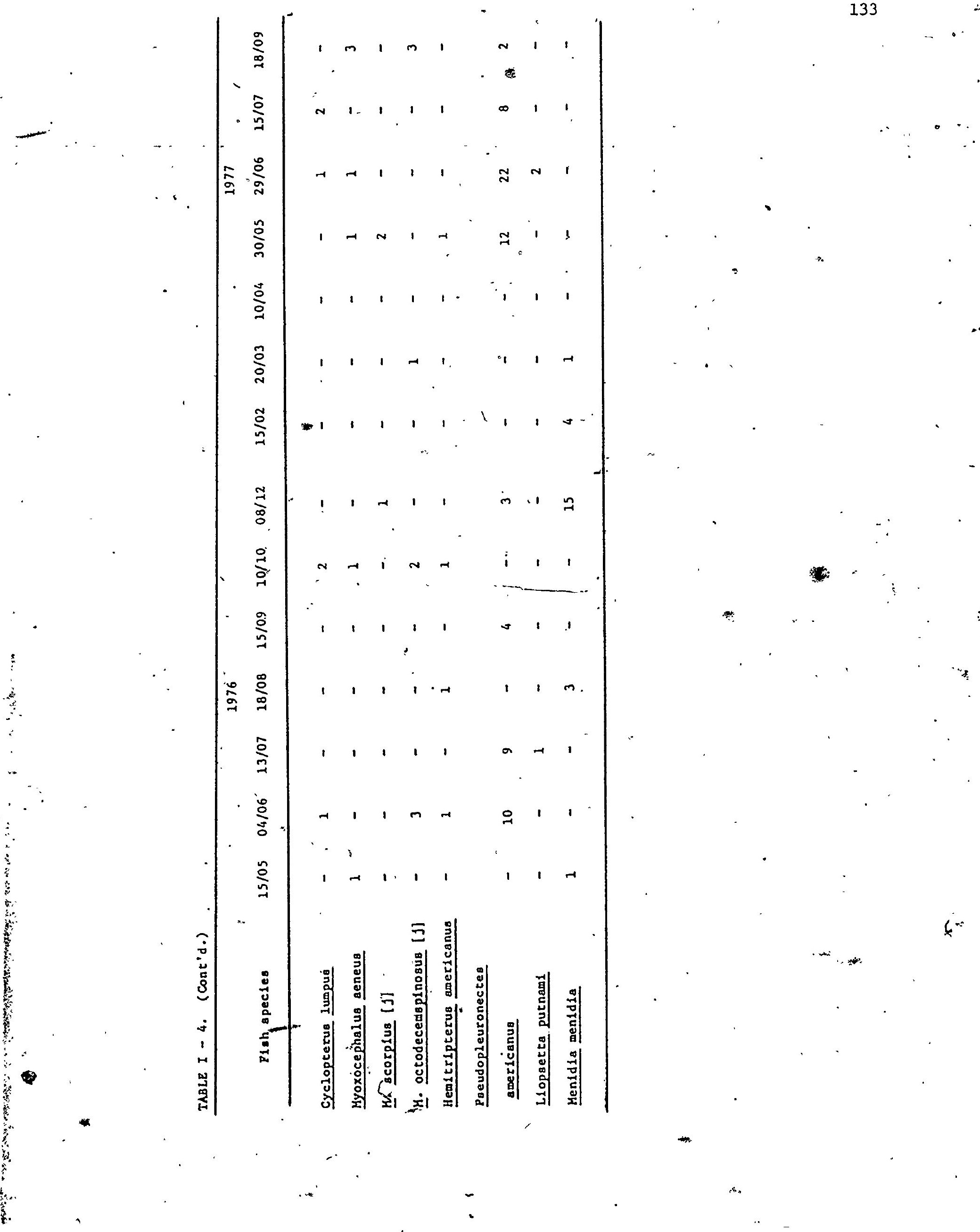




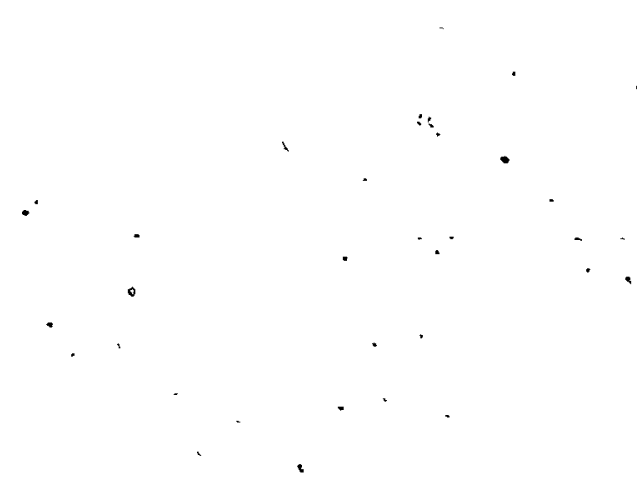

$\cdot$

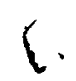

FIGURE I - 9. Seasonal occurrence and abundance of pelagic fishes and dogfish at deep stations in the Bay of Fundy and
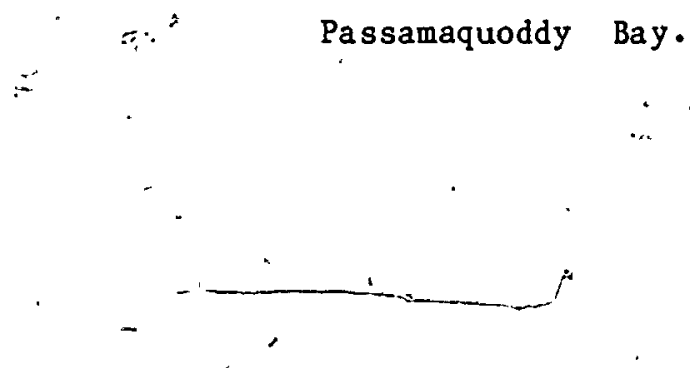

the
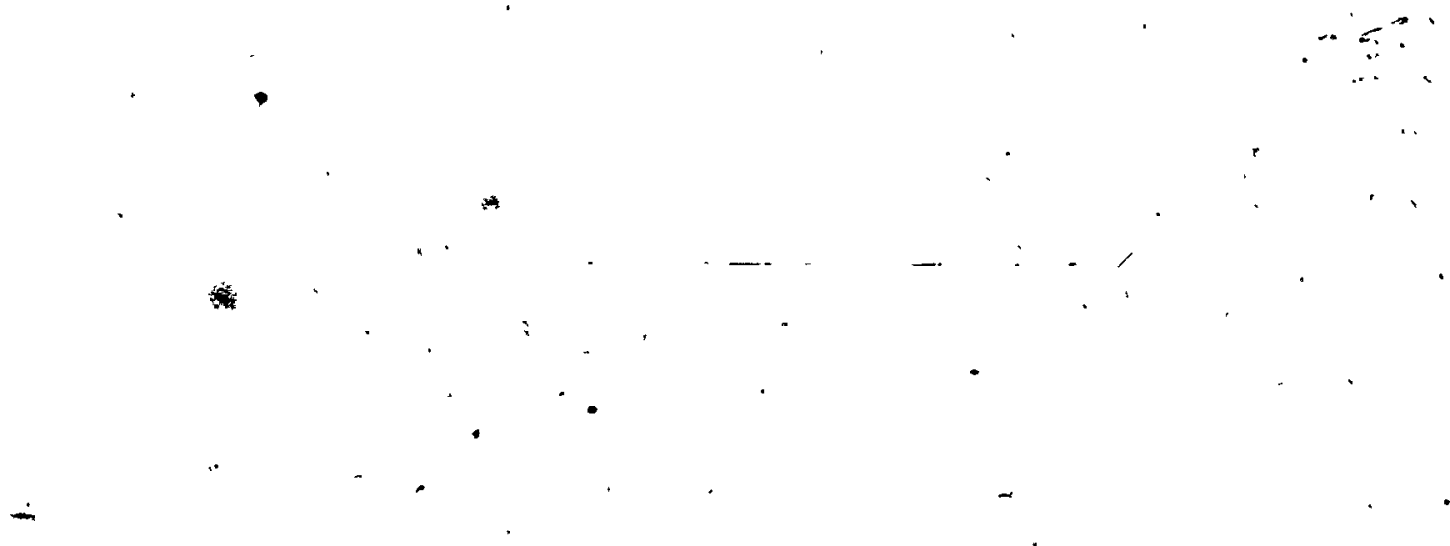


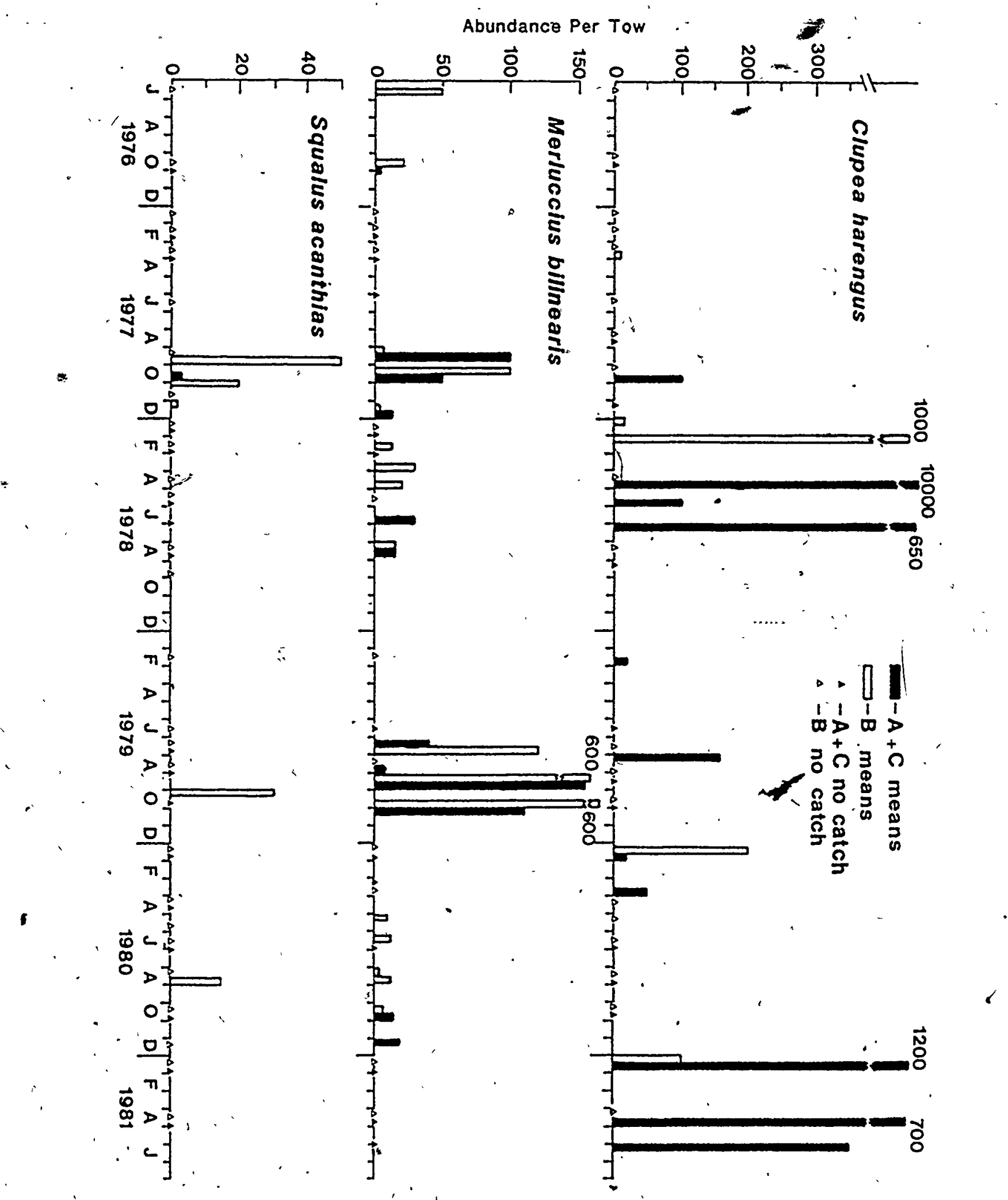


replacing the gadoids (Fig. 5). Herring and smelt were also a regular component in estuaries during spring and fall (Table 3).- Adult smelt were present at offshore sites in Passamaquoddy Bay in mid-summer as observed by Tyler (1971). In most winters, juvenile herring $(10-20 \mathrm{~cm})$ were abundant at ffshore. sites, particularly inside Passamaquoddy Bay (Fig. 9). Catches were variable and probably depended on their schooling behaviour. Tagging experiments also indicate herring move'from inshore during summer to deeper water in winter (McKenzie and Tibbo 1961). Six species of sculpin (Table 2) were commonly encountered at deep stations of which two, longhorn sculpin (Myoxocephalus octodecemspinosus) and sea raven (Hemitripterus americanus), were abundant, regular components (Fig. 10). Juveniles of most species were common at beach sites in summer (Table 4) and at station $A$ in winter (Table 2). Increases in abundance of sculpins at station $B$ during winter, were observed (Fig: 10 ) and may be the result of migration out of Passamaquoddy Bay. Two 'small s̄pecies, Arctic hooker sculpin (Artediellus uncinatus) and mailed sculpin (Triglops murrayi) were winter periodics at station A. They were perhaps more abundant than catch rates indicated $(2-5 /$ tow $)$ because their maximum size range was at the lower limit lof catchability for our trawl.

The blennoid-1ike fishes were representêd by seven species (Table 2) of which one, ocean pout (Macrozoarces americanus) was a regular at offshore stations in Passamaquoddy Bay (Fig. 10) and another, rock gunnel (Pholis gunnellus), was a regular component at beach sites (Table 4). . Ocean pout abundance was generally highest in Passamaquoddy Bay in early summer and declined thereafter (Tyler 1971; present study). Abundance of ocean pout usually increased at station $B$ in late summer and fall, 
137
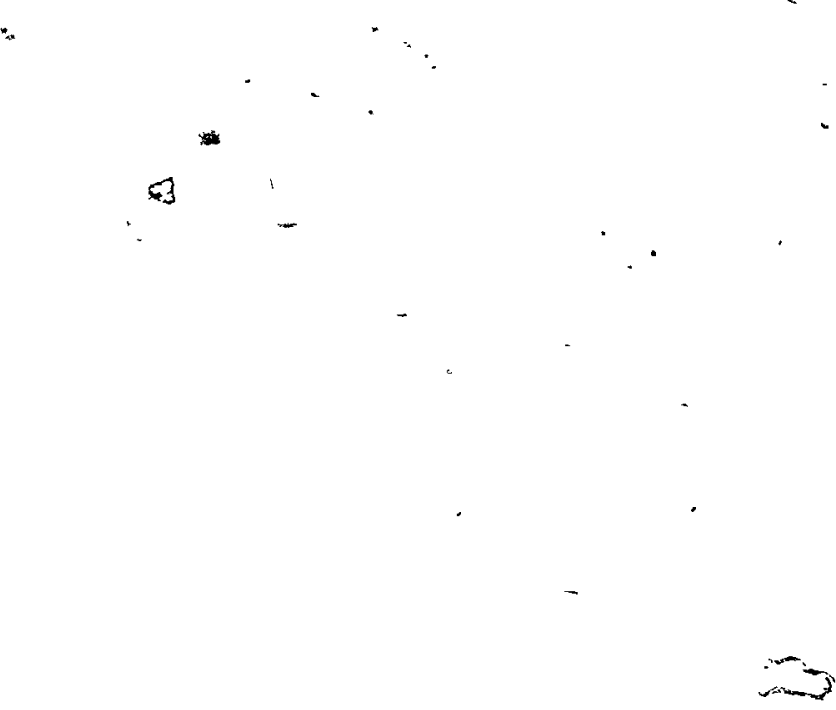

FIGURE I - 10. Seasonal occurrence and abundance of sculpins and ocean pout at deep station in the Bay of Fundy and Passamaquoddy Bay.

3 


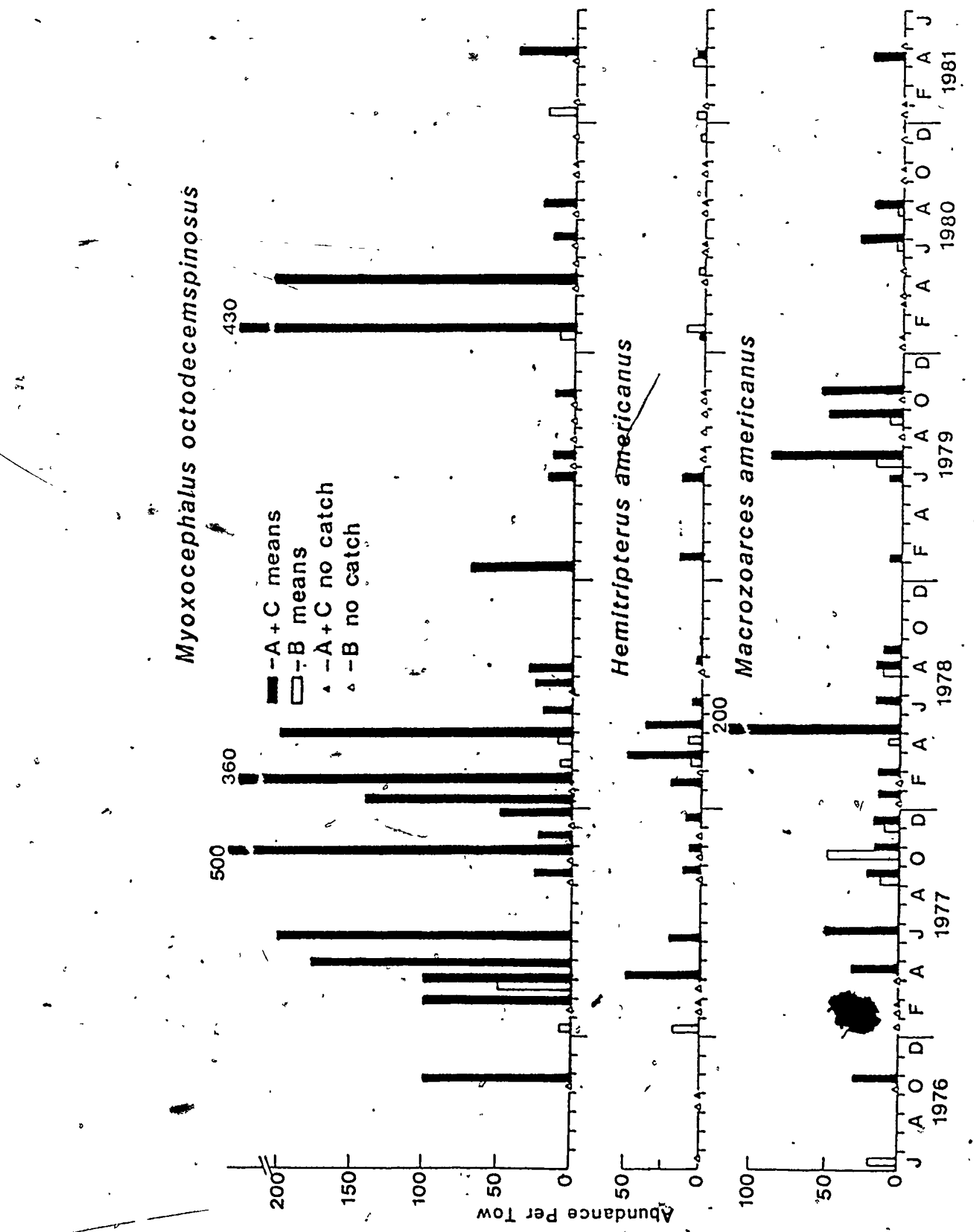


suggesting-movement. from Passamaquoddy Bay, to the Bay of Fundy. Since this movement was most prounced during the warm summer of 1977 (Fig. 10), it may be a response to avold warm temperatures (01sen and Merriman 1946). Movement of pout is generally thought to cover only short distances (Orach-Meya 1975; Sheehy -et a1 1977).

other blennoids occurred infrequentiy at station A (Table 2). Selectivity of our shrimp trawl may have been a factor in these low catches. One species, radiated shánny (U1varia subbifurcata) which was thought to be rare in Passamaquoddy Bay (Leim and Scott 1966), was often captured (5/tow) at station A during winter. : SCUBA searches during summer revealed thăt shanny were abundant inshore, under rocks. in" 6-9 m of water (Dadswell and Melvin; pers. observation).

Five spectes of skate were captured during the study (Table 2). Two

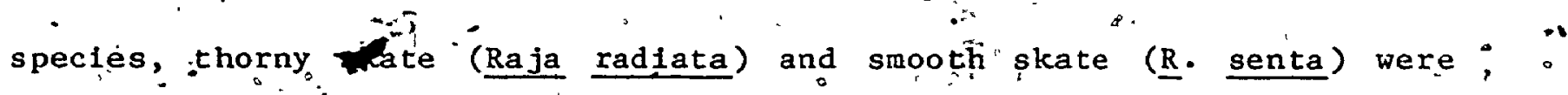
common, regular components of the offshore site in the Bay of Fundy. Two

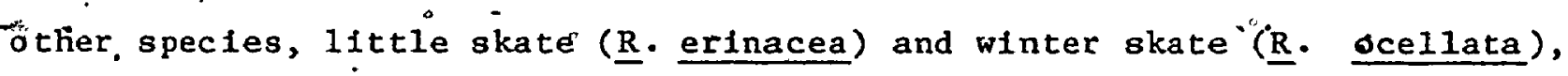
were regular components of station A in Passamaqugddy Bay. Some seasonal movement into Passamaquioddy Bay was exhtbited:" Abundance of smooth and thorny skate at station A increased during sumier and declined after late f́al1. : Juveniles of thorny, little, and winter skàte were often captured. at beach sites dứring summer (Tablé. 3). "Raja laevis was coilected occagionally àt site, $B$.

Several smaller fishes were captured at inshore sites only but again this inay be an artifact of sampling gear three-splne stickleback (Gasterosteus aculeatus) (Table 4). Other "sticklebacks were more or less confined to estuarine areas . (Tabie 3). Mummithog " (Eundulus hetergcittus) and silversides 
(Menida menida) occurred mainly in estuaries during summer but were part of the winter community at beach sites (Table 4).

Communities and Diversity

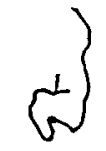

Fish communty composition in the study area varied according to site and season. If juventles and adults of some dominant species are considered as separate taxonomic units (Table.2), coefficients of community simflarity show the strongest similarity between ha (eg. deep, soft bottom), and between the summer community of one habitat and the winter community of the next seaward habitat (Table 5 ). In general, movement of assemblages was from. inshore in summer to offshore in. winter. with a return movement in spring (Fig. 11). Some species, however, exhibited a.partial reverse of: this pattern (tomcod, ocean pout).

Specific groupings of fish were segregated among the available habitats as dictated by season. The "estuarine" assemblage was dorinated by warm water, euryhaline species, including sticklebacks, silversides, mummichogs, and juvenile clupeôfữ. Most of this group moved, to adjatent, Inshore marine habitat in winter (Table 3, 4), but tomcod and smelt moved in the reverse direction to form a winter estuarine group (Table 3).

- The summer "beach" assemblage, consisted of regulars such as three- spline "stickleback" and rock gunnel and perlodics including juvenile "gadolds, juvenile-sculpinb, flounders, and juventle alosolds. Juvenile gadojids (pollock, white hake, and tomcod) dominated thlo assemblage in early summer but were displaced by steadily increasing numbers of 


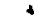

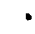

141
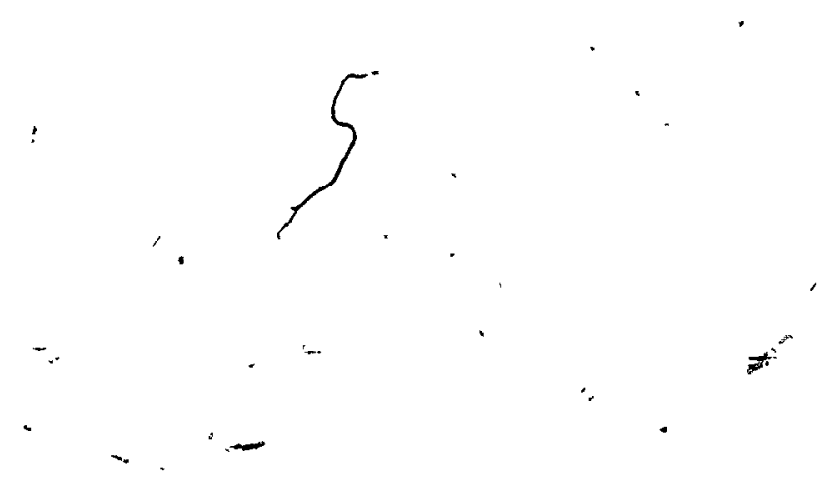

$\therefore$

$\infty$

$\because$

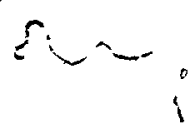

4.

$\bullet$

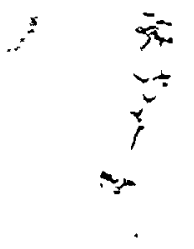

$a$

TABLE I - 5. Coefficients of percent similarity l among seasonal fish".

communities in the lower Bay of Fundy.

ans

$\cdot$.

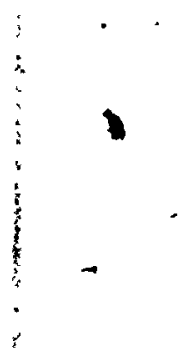

$\because$

$+$

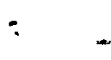

5

0

$\therefore$

0

$: t$ 


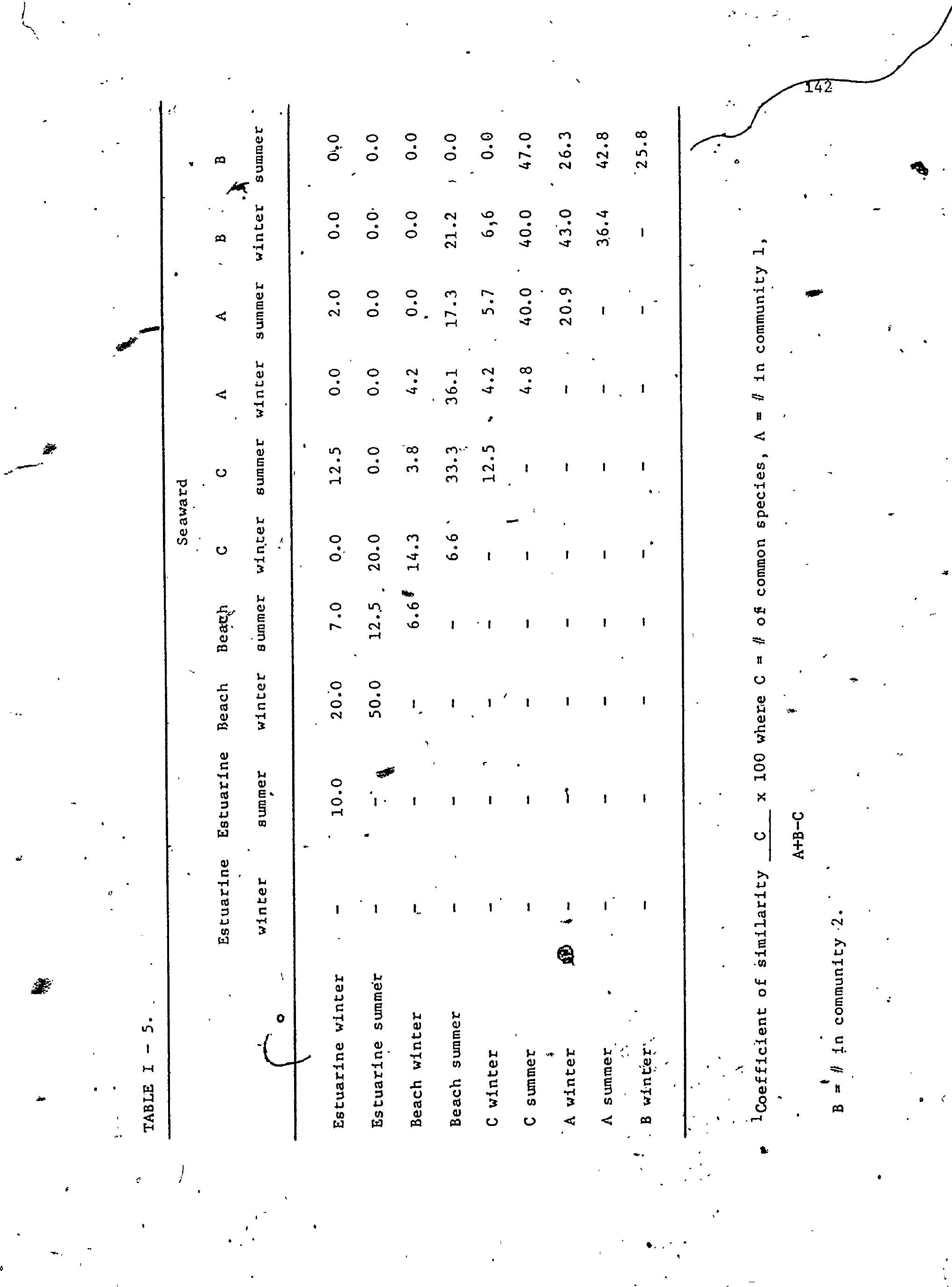




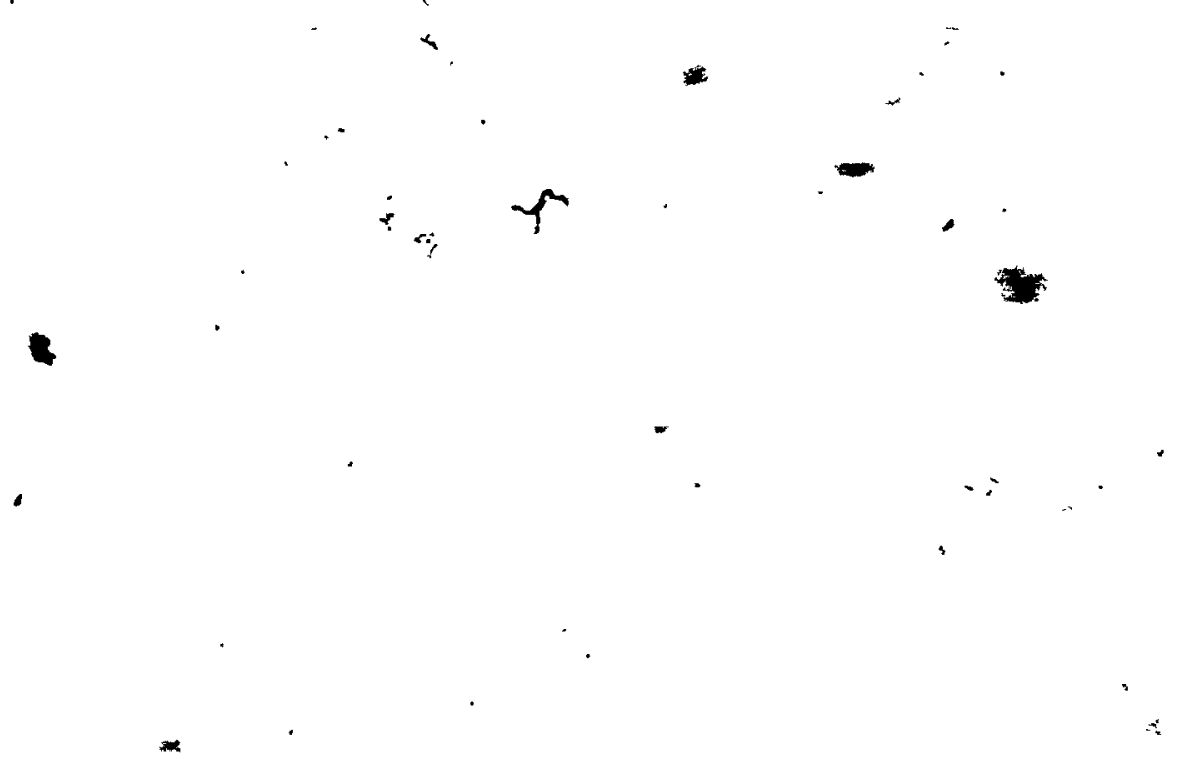

FIGURE I - 11. Communities of fishes occurring at each site divided into summer compọnenţ (SC), winter component (WC), and regular
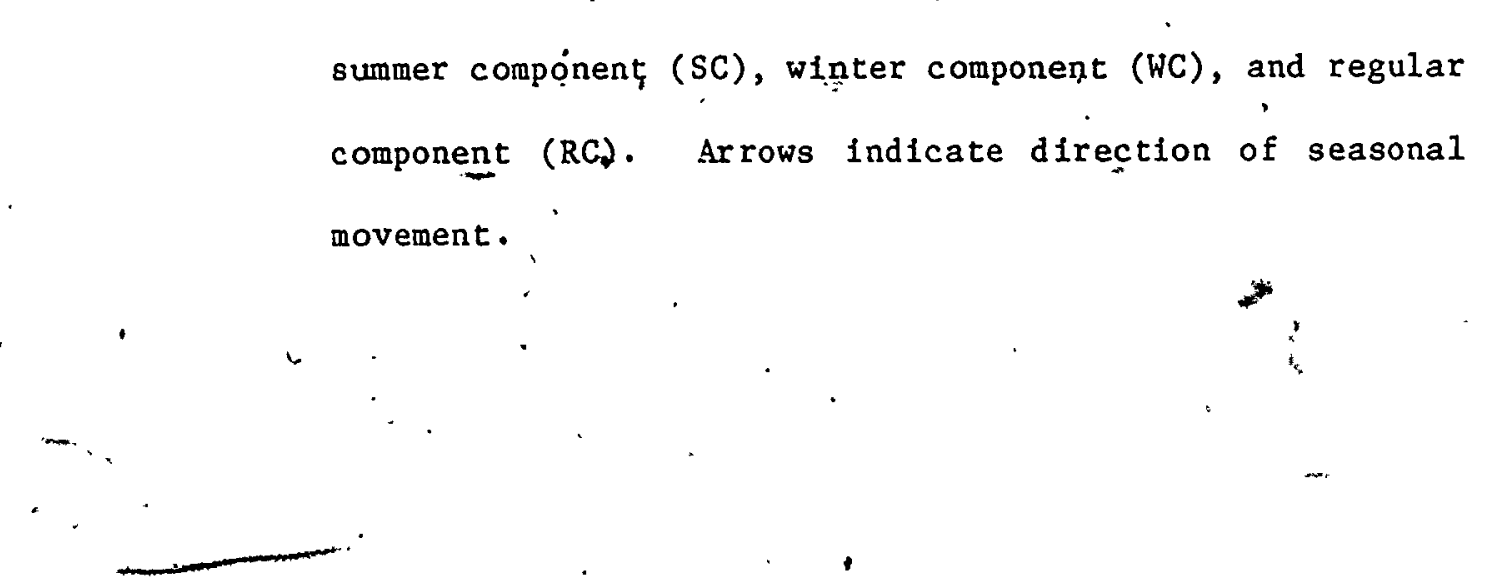
movement.
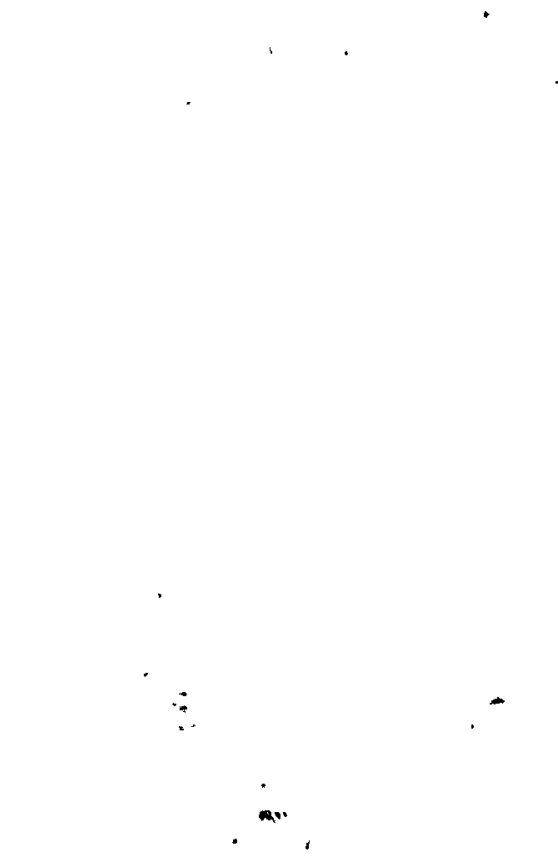


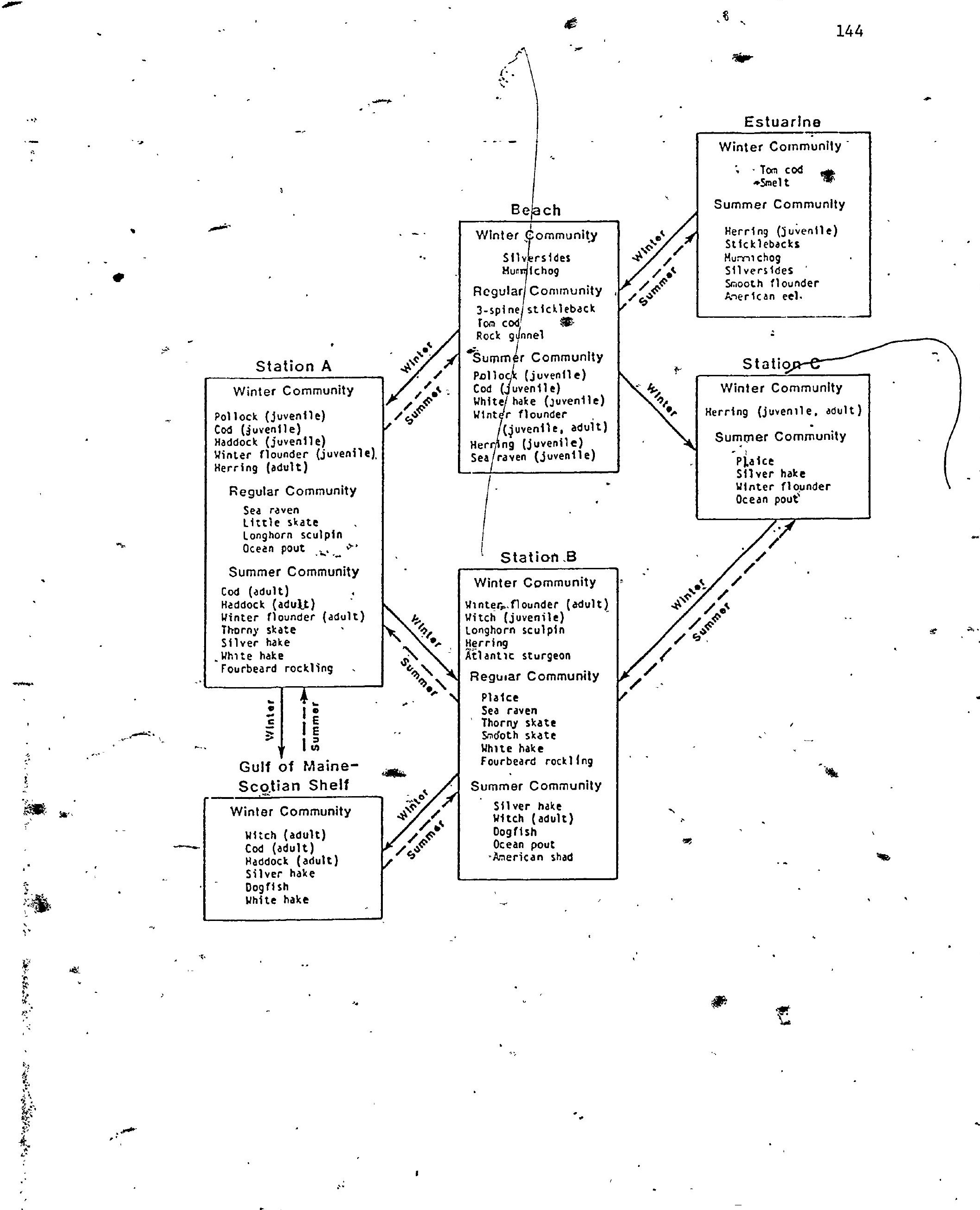


clupeoids in late summer (Fig. 5). Numerous other postlarval and juvenile fishes, including four-beard rockling and-lumpfish, appear in the beach zone during the summer (Table 3). In late fall most of this assemblage left the beaches and occupied deep sites in Passamaquoddy Bay. Herring concentrated at the soft-bottom station $C$ and the gadoids, sculpins, and winter flounder (juveniles) at the hard-bottom station $A$. Three-spine stickleback and rock gunnel remained at beach sites over winter and were joined by silversides and mummichog to form a winter grouping (Table 4).

During sumer an "offshore, hard-bottom" assemblage consisting of adult gadolds (cod, haddock, white hake), adult flounders (winter, yellowta11), ocean pout, adult sculpins, and skates assembled. Inside Passamaquoddy Bay. Seà raven, Ionghorn sculpin, ocean pout, and little skate remained at this site over winter to be joined by juvenile fishes from the beach zone. The other species apparently move to offshore sites In the Bay of Fundy and/or to the Scotian Shelf (Edwards 1965; Kulka and Stobo 1981).

- The "offshore, soft-bottom" assemblage consisted of plaice, witch Floundgt, white hake, four-beard rockling, and skates. This group "at" ". statipn $B$ was the most stable assemblage studied and had the largest regufar component. Conversely, simflar communtites which occurred at the shollower, spft-bottom site $c$ were the most seasonaily dynamic (Fig. 11). Adult witch and most white hake left station $B$ in winter, possibly for grolunds further offshorë in the Gulf of Malne (Powles and Kohler 1970; Kulka and Stobo 198i) and were replaced by adult winter flounder and longhorn sculpin, possibly from Instgle Passamaquoddy Bay or other adjacent inshore sites (McCracken 1963). 
Superimposed on the two offshore, essentially benthic, fish communities was. a seasonal pelagic component. In sunmer, sịlver hake was - 1

the dominant species." During fall, diversity increased with the arrival of $\operatorname{dog} f i s h$, butterfish, and shad. In winter, herring dominated the pelagic component of the assemblage at all deep sites (Fig. 11). Diversity, expressed simply as number of species captured, varied appreciably at beagh sites during the year. Diversity was 2-5 spectes in winter-spring, 9-13 species in summer, and 4-6 species, in fall-winter (Fig. 12). Total number of species captured at inshore sites was 35 , 新 compared to ,51 specles "čaptured at offshore șites.

Diversity of communities at deep sites $(90+m)$ was more stable on an annual basis because of the seasonal influx and-departure of species to adjacent habitațs (Fig. 13). Species number varied between 7 and 17 fishes at station $B$ and 7 and 20 fishes at station $A$, fluctuating about $a$. *mean of 12/sampling trip. During 1965,.. Tyler (1971) observed a higher mean diversity of 17 species/trip at station $A$ with a maximum occurrence of 24 . The difference between his observations and ours may be accounted for partially by the decline in haddock abundance since 1965 and the recent absence of plaice from this site, and partially by his use of a $0.6-\mathrm{cm}$ codend liner, which would have retained small, occasional species $\therefore \therefore .$. more often than our $2.5-\mathrm{cm}$ codend.

Highest diversities occurred during winter at station $B$ and during summer at station A (FIg. 13) as a result of seasonal exchange between these shtes and the arrival of periodics. The highest diversity recorded during the study period occurred at stations $A$ and $B$ during the fall of: 1977, colniciding with maximum temperatures recorded at these sites between 1976 and 1981. Similarly, lowest winter diversity recorded at 
$\therefore 147$

FIGURE I - 12. Monthly diversity of Fishes at intertidal stations 3 and 8 in Passamaquoddy Bay. Species/month for station 3 is mean of 1976 and 1977 samples.

尖 


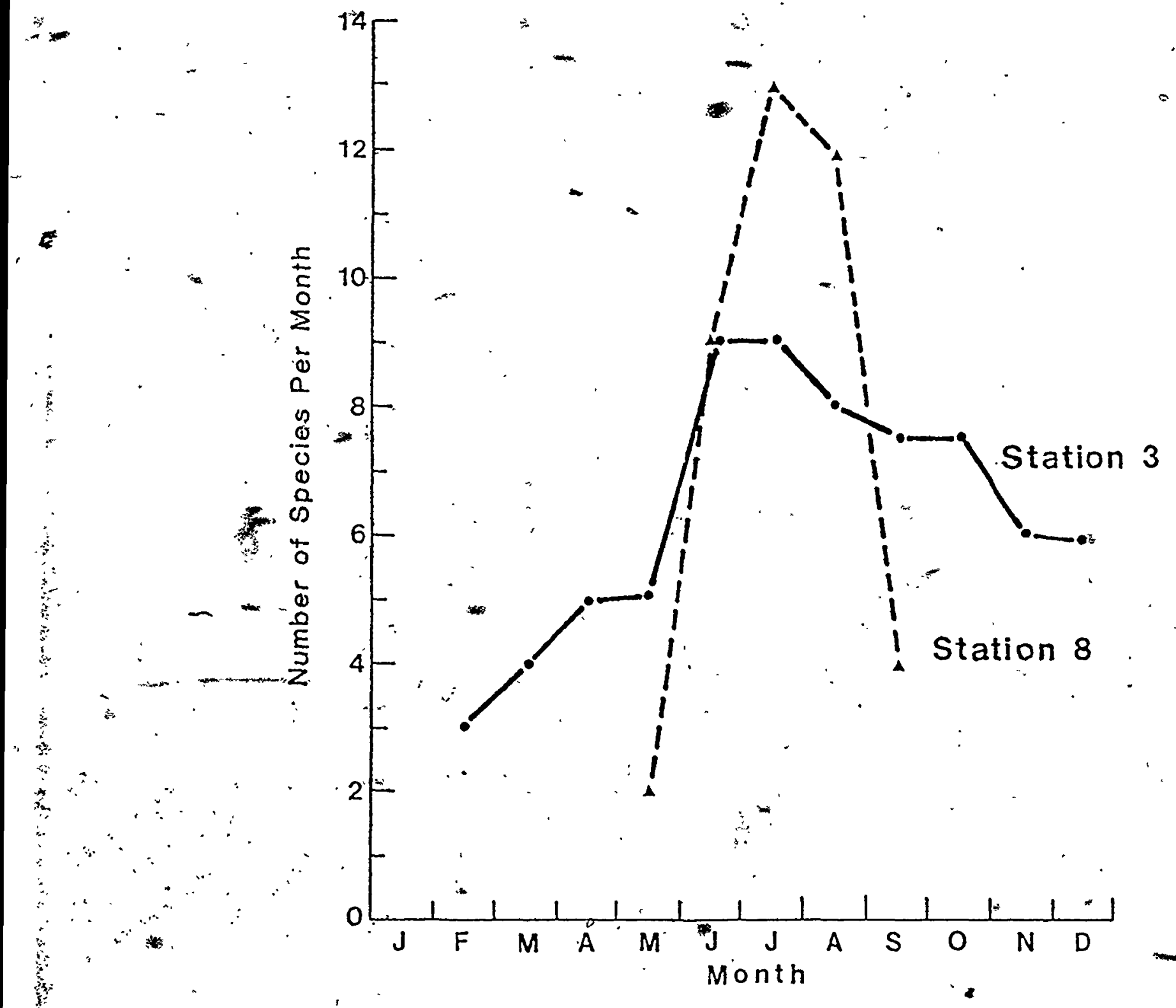




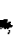

FIGURE I - 13: Seasonal diversity of fishes at station B (Bay of Fundy) and station A (Passamaquóddy Bay). Vertical bars represent range among replicated collections.

"'



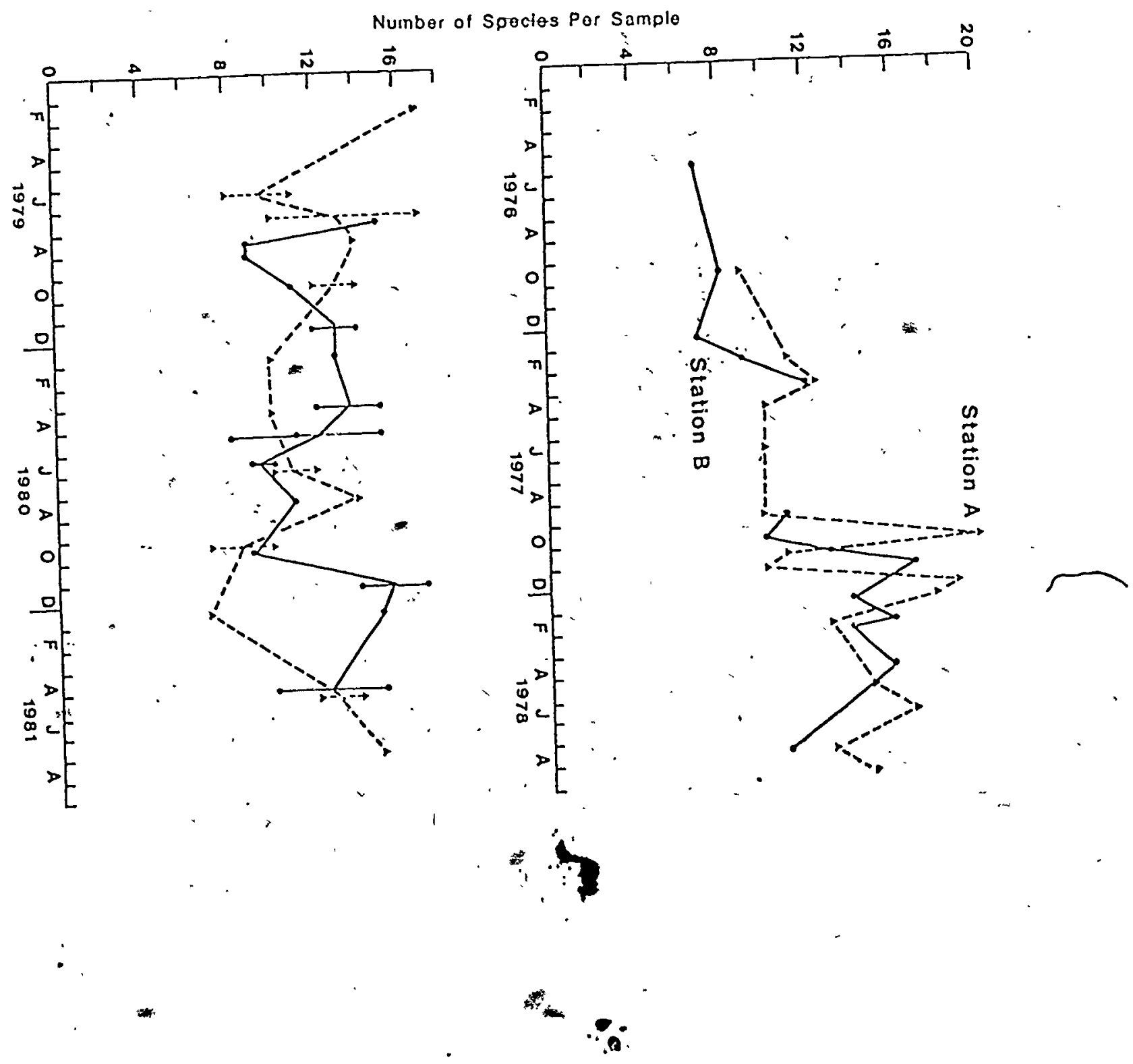

露 
station $A$ occurred in the coldest winter of 1980-81 (Fig. 2). Diversity at station C, the mid-depth site, decreased from 13 species in May 1978 temperature.

\section{GENERAL DISCUSSION}

Most authors have related the occurrence and distribution of adult benthic fishes in the North Atlantic to substrate type and temperature (Edwards 1965; Colton 1972; Scott 1976) and have shown there is a marked 1
seasonal variation (Lux and Nichy 1971; Jeffries and Johnson 1974). Our findings agree and indicate yearly differences are influenced mainly by mintmum winter and maximum summer temperatures. Species occurrénce, abundance, and diversity changed dramaticalily in response to seemingly small changes in the temperature regime. Jeffries and Johnson (1974) report a similar observation concerning winter flounder abundance over a seven year period in Narragansett Bây. Pelagic and semi-pèlagic species (herring, sllver. hake) demonstrated little or no' substrate preference. occurrence" was related" to annual migratory behaviour.

- Seasonal movements of the various species was largely from an inshore, shallow water locality in summer to an offshọre, deepwater locality in winter with a reverse movement occurring in spring. Cause of this movement may have a large physiological component related to temperature effects on the osmoregulation of many marine fishes. (Potts and Parry 1964). In the-southern part of their range, fịsh such as winter flounder migrate onshore in winter (Bigelow and Schroeder 1953) in response to avallability of preferred temperature but never encounter the. low temperatures found at northern latftudes. Tomcod, a specles known to 
produce an antifreeze in their blood (Fletcher et al 1982), was one of the few fishes exhibiting onshore migration to, lower salinitles during winter in this area. For many specles (pollock, herring, white hake), migration from inshore habitat to offshore is unidirectional for the. Individual, since each year the beach commanity çonsists of the new $0+$ year-class For other specles (winter flounder, juvenile sculpins, radiated shanny) the return inshore is an annual occurrence," triggered perhaps as much by resource avallability and predator avoidance $\ddot{a}$ s by physiology.

Tyler (1971) found that white hake was the only spêtcies where large. individuals moved independently of small individuals in Passamaquoddy Bay. We found obvious differences in size-class distributions and abundance between sưner and winter populations of winter flounder, witch, cod, and pollock at deep sites and a complete lack of most adult.

fish in shallow water. This suggests marked segregation between juveniles (at least 0+ age group) and adults for these spectes. The use of shallow water habitat as nursery area by fishes of cornumercial importancë has recelved little, attention in the western North Atlantic. In Europe, this fact has been amply demonstrated for many fish species, Including cod and pollock.(Zijlstra 1972; Rauck and 2Pjlstra 1978; Daan 1978; Burd 1978). The extenstive use of beach habitat as nursery by these fishes makes them susceptible to coastal pollution impacts and puts their adult fistiérlés "at risk to coastal degradation and development.

Decline in haddock abundance in Passamaquoddy Bay since 1965 colncides, with increased numbers of cod. While previous studies indicate 1itţle Interacțian between thèsẹ two specles (Tyler 1972; Jones 1978), competition betweęn cod and haddock may be respongtble for the continued 


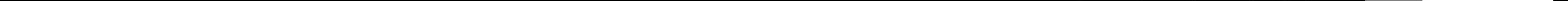




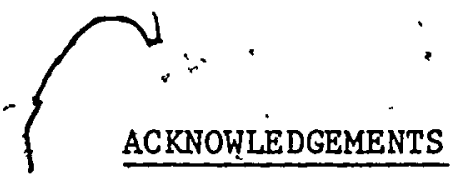

We thank Captaln Tom Allen and Floyd Johnson, crews of the PANDALUS II for their help. Bill McMullon and Frank Cunningham prepared the flgures and Brenda Fawkes and Yvonne Pepper typed the manuscript. J.S. Scott, W.B. Scot,t, D. Markle and D.J.' Scarra,t, reviewed the manuscript. Thanks aiso to frany of the stäfy at the Huntsman Marine Laboratory. The work done by J.S. Macdonald was in partial fulfilment of Ph.D. studies supported by NSERC operating and strateglc grants to Dr". R.H. Green.

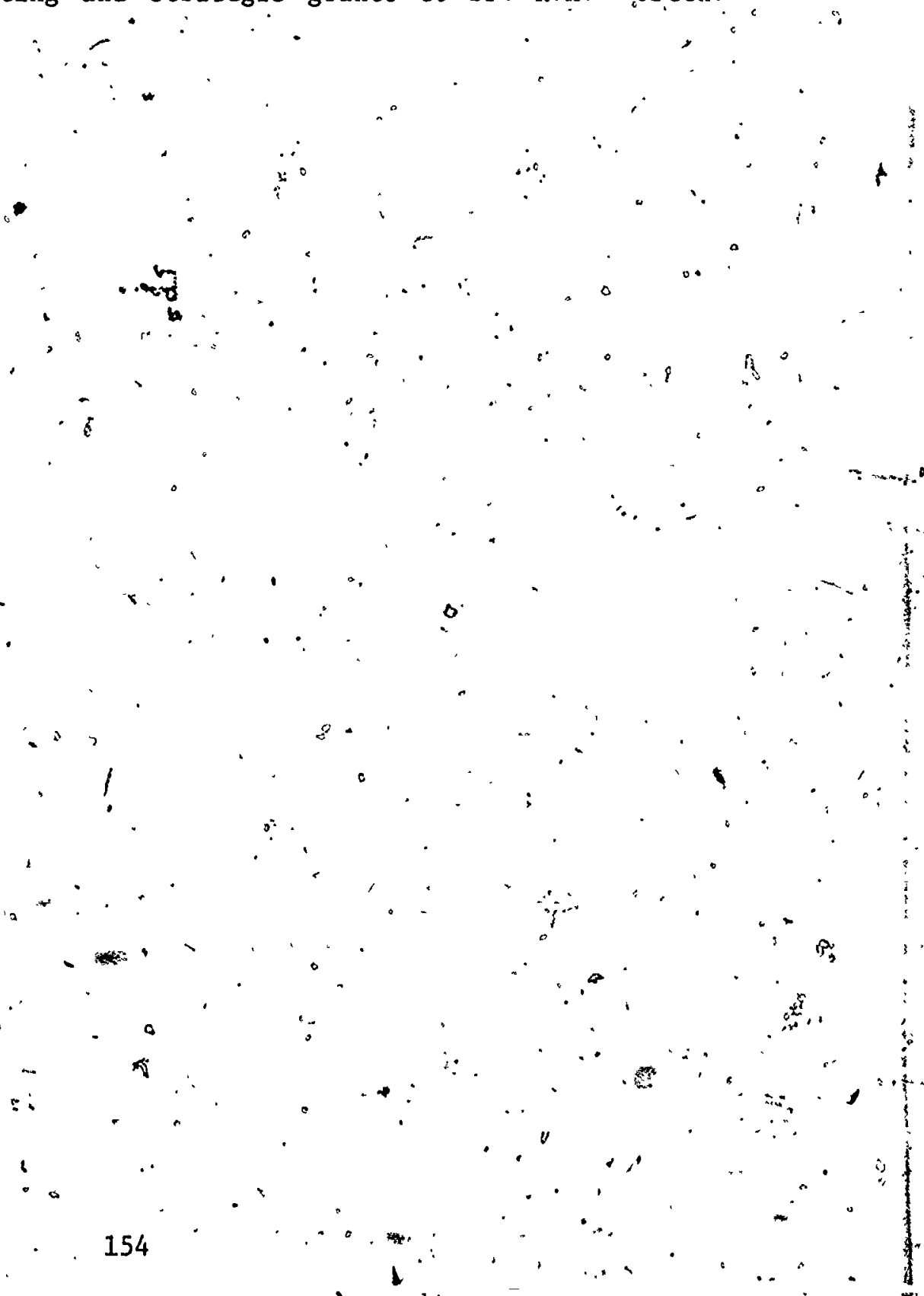


-BATTLE, H.I. 1930. Spawning perlodicity and embryonic death rate of Enchelyopus elmps (L.) in Passamaquoddy Bay.* Contrib. Cañ. Biol. Fish. N.S. 5: $361-380$.

BIGELOW, H.B., and W.C. SCHROEDER. 1953. Fishes of the Gullf of Maine. . Fish. Bull. U.S. Fish Wild1: Serv. 53: $: 57 \mathrm{p}$.

BURD, A.C. 1978. Long-term changes in North. Sea herring stocks, p. 137153. In G. Hempel [Ed.] North Sea flsh stocks - recent changes and their causes, Rapp. Pro. Verb: Reun. Cons. Inter. Explor. Mer 172.

COLT@̣, 'J.B. 1972. Temperature trends and the distribution of groundfish. in continental shejlf waters, No'va scotia to Long Island. Fish. Bul1. 70: 911-914.

N. 1978. Changes in cod stock and cod fisheries in the North Sea, p. 39-57. In G. Hempel [Ed.] North Se'a fish stocks - recent changes and their causes. Rapp. Pro. Verb. Reun. Cons. Intẹ... Explor. Mer 172 .

EDWARDS; R.I: ${ }^{\circ}$ 1965. Relation of temperature to fish abundance and distribution in the southern New England, area. Intern. Comm. Northw. At1. F1sh., Spec. Publ." 6: 95-110:

FLETCHER, G.L., C.L. HEW, and S.B. JOSHI. 1982. Isolation and characterization of anti-freeze glycoproteins from the frostfish, Mlcrogadus tomcod. Can. J. Zool. 60: 348-355.

HACUNDA, J.S, 1979. "Food resource partitioning by a demersal fish community in a coastal area of the Gulf of Maine. "M.Sc. Thesis, Uniy. of Maine, Orono, 49, p. 
HARE, G.M. 1977. Atlas of the major Atlantic coast fish and invertebrate resources adjacent to the Canada-United-States boundary areas. Fish. Mar. Serv. Tech, Rep. 681: 97 p.

JEFFRIES, H.P., and W.C. JOHNSON. 1974. Seasonal distributions of bottom fishes in the Narragansett Bay area: seven-year variations in the abundance of winter flounder. J. Fish. Res. Board Can. 31: 1057 1066.

JONES, R. 1978. Competition and co-existance with particular reference to gadoid fish species, p. 292-300. In G. Hempel [E்.] North Sea * fish stocks - redent changes and their causes. Proc. Verb. Reun. Cons. Int. Explor. Mer 172.

KEAST, A. 1970. Food, specializations and bioenergetelc interrelations 1 ps in the fish faunas of some small Ontario waterways, p. 377-411, In J.H: Steel [Ed.] Marine Food Chains. Univ. Calif. Press.

KULKKA, D.W., and W.:T. STOBO. 1981. - Winter distribution and feeding of mackerel, on the Scotian Shelf and outer Georges Bank with reference to the winter distribution of other finfish species. Can. Tech. Rep: Fish. Aquat, Sci. 1038: 38 p.

LEIM; A.H., and.W.B. SCOTT. 1966. Fishes of the Atlantic coast, of Canada. Fish. Res. Bơàrd Can. Bul1. 155: -485 p.

LUX, F.E., and F.E. NRCHY. 1971." Number and lengths by season of fishes caught, with an otter trawl near Woods- Hole, Mass., September 1961 to December 1962." NOAA Nat. Mar. F1sh. Sery. Spec. Scien. Rep. F1sh. 622: 15 p.

MCCRACKEN, E.D. 1963: Seasonal movements of the winter flounder, Pseudopleuronectes americanus (Walbaum), on the Atlantic coast. iJ. 
Fish. Res. Board Can., 20: 551-586.

MCKENZIE, R.A., and S.N. TIBBO. 1961. Herring movements in the Bay of Fundy and Gulf of Maine, 1957 and 1958. J. Fish. Res. Board Can. 18: $\quad 221-252$.

Mogre, R.H. 1977. Variations in the diversity of summer estuarine fish populations in Aransas Bay, Texas, 1966-1973. Estuar. Coastal Mars Sci. 6: 495-501.

MUSICK, J.A. 1973. A meristic and morphometric comparison of the hakes Urophysis chuss and $\underline{\text { U. }}$ tenuis (PIsces:Gadidae). F1sh. Bull. 71: 479-488.

OLSEN, Y.H., and D. MERRIMAN. 1946. Studies on the marine resources of southern New England. IV.- The biology and economic importance of the ocean pout, "Macrozoarces americanus (Bloch and Schnelder). - Bulle Bingham Oceanogr. Collect. Yale Unvi. 9: 1-184. ORACH-MEYA, F.L. '1975. Distribution and abundance of ocean pout, Macrozoarces americanus, (B1ock and Schnelder, 1801) in the western North Atlantic Ocean. M.Sc. The Us; Univ: Rhode Island, Kingston, $108 \mathrm{p}$.

POTTS, W.T.H., and G. PARRY. 1964." Osmotic and Ionic Regulation in Animals. MacMililan, N.Y., N.Y., 423 p.

POWLES, P.M., and A.C. KOHLER. 1970. . Depth distributions of various stages of. witch flounder (Glyptocephalus cynoglossus) off Nova Scotia and In the Gulf of St.Lawrence. J. Fish: Rès. Board Can. 27: $2053-2062$.

QUINN, N.J. 1980. Analysis of temporal changes in fish assemblages in, Serpentine Creek, Queensitand, Env. Biol. Fish. 5: 117-133. RAUCK, G., and J.J." ZIJLSTRA. 1978. On the nursery-aspects of the Wadden 
Sea for some commercial fish species and possible long-term changes, p.266-275. In G. Hempel [Ed.] North Sea.fish stoćks- recent changes and their causes. Rapp. Proc. Veř . Reun., Cons. Inter. Explor. Mer 172.

RICHARDS, S.W. 1963. The demersal fish population of Long Is land Sound. Bull. Bingham Oceanogr. Collect. Yale Univ. 18: .. 1-101.

SAILA, S.B. 1961. A study of winter flounder movements. Limnol. Oceanogr. 6: $\cdot 292-298$.

STEINER, R.G. 1976. Neritic reef fish communities - some problems and a possible solution. In C.A. Siménstad and S.J. Lipovsky [Eds.] Fish food habit studies. First Pacific N.W. Tech. Workshop, 193 p. SCOTT, J.S. 1976. Summer distribution of groundfish on the Scotian Shelf, 1970-74. Fish. Mar. Serv. Tech. Rep. 635: 13 p., 37 ṭig. SCO'T,- J.S.' 1980. Occurrence of pollock, Pollachius virens, and sand lance, Ammodytes sp. larvae in the Bay of Fundy. J. Northw. AtI. Fish. Sc1.* 1: 45-48:

SHEEHY, P.J., S.Y.K. SHERIOUDA, A.J. ALTON, S.B. SAIIA, and S.M. - CONSTANTInIDES. 1977. The ocean pout: an example of underexploited fisheries-resource development. Mar. Fish. Rev. 36: $5-15$

TYLER, A.V. 1971. Periodic and resident components in communities of Atlantic fishes. J. Fish. Res. Board Can. 28: 935-946. .

TYLER, A.V: 1972. Food resource division among northern marine demersai flshes. J. Fish. Res. Board Can. 29: '997-1003.

VAN GUELPEN, L., and C.C. DAVIS. 1979. 'Seasonal movements of the winter floünder, Pseudopleuroniectes americanus, in two contrasting inshore locations in Newfoundland. Trans. Am. Fish. Soc. 108: 26-37." is 
WAREEL, H.E.; and D. MERRIMAN. 1944. Studies on the marine resources of -southern New England. I.-Analysis of fish papulation of the shore 5 zone. Publ. Bíngham Oceanogr. Lab., Art. 2: 1-91. WILDISH, D.J., and M.J. DADSWELL. Sublittoral Gammaridae of soft sediments in the Bay of Fundy. Crus. Biol. 3: - in press.

ZIJLSTRA, J.J. 1972. On the importance of the Wadden Sea as a nursery area In relation to the conservation of the southern North Sea fishery resources: Symp. Zool. Soc. (Lond.) 29: 233-258. 


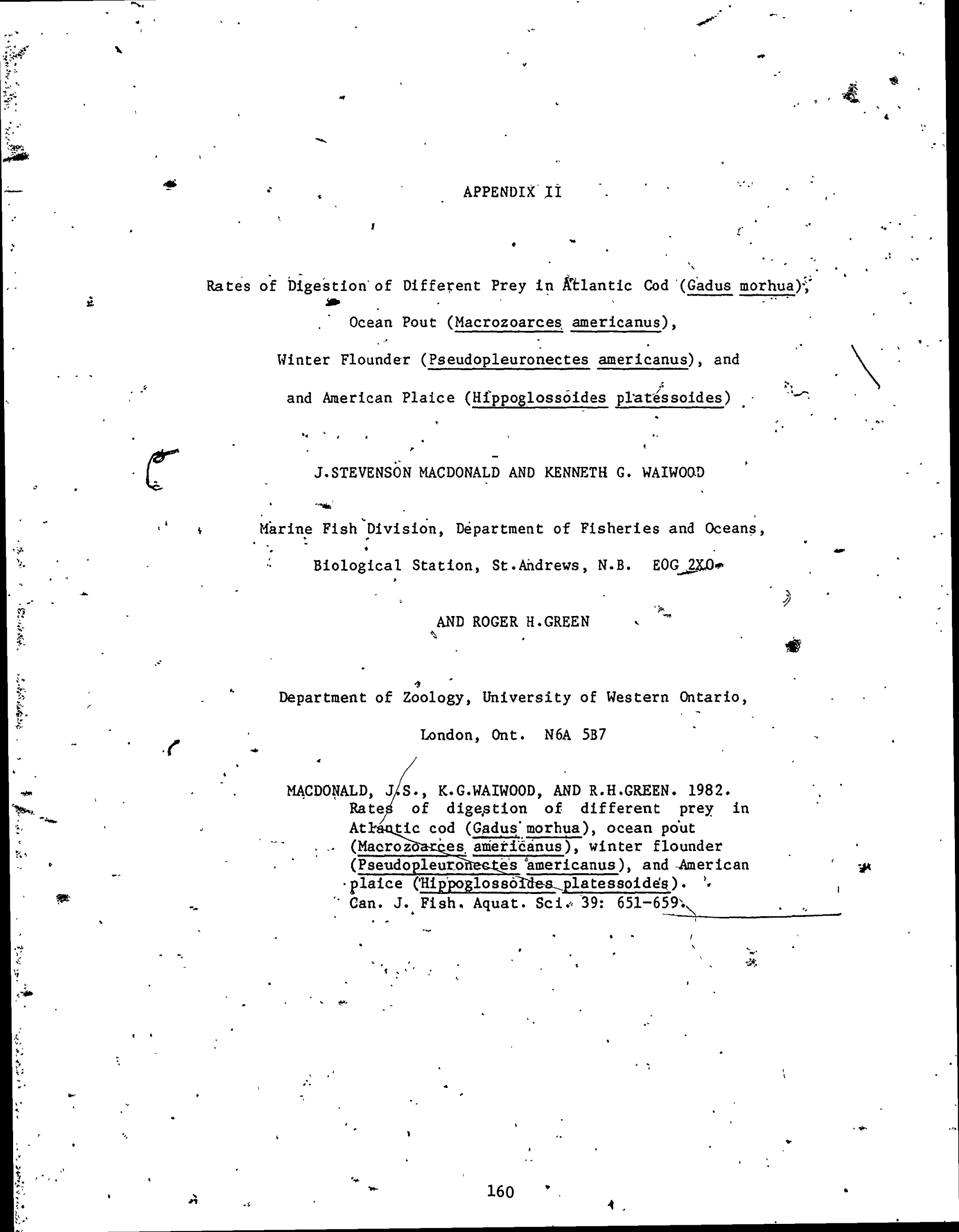


Variation. in the digestion pattern of different prey is an important variable in an evaluation of the diet composition, food preference, or consumption rate of wild fish. Estimates of dafly ration based on gastric evacuation models require relatively accurate estimates of the rate of stomach emptying which is influenced by many factors, including prey type (reviewed by Windell 1978; Conover 1978). Unfortunately,

information about prey-specific variation in digestion patterns is restricted to few predator-prey combinations, and many of these involve non-preferred or processed (eg. dissected or frozen) prey i.tems.

Evaluation of diet composition based on the percentage occurrence of prey in the stomach may be biased by differential rates of prey digestion (Héss and Rainwater 1939; Cailldet 1976; Gaare et, a1 1977; Berg 1979). Conversion factors have been calculated to compensate for this.

This study was done to investigate the digestion pattern of three common prey (Yoldia sapotilla, Tmetonyx clcada, and Nephtys inctsa) in four spẹcles of syntopic benthic. fish (ocean pout (Macrozoarces americanus), Atlantic cod (Gadus morhua), winter flounder (Pseudopleuronectes americanus), and American plaice (H1ppoglossoldes platessoldes)). Rate of elimination from the stomach was Investigated by visual indexing of aigestion stage to calculate the length of time the préy remalned identifiable to species and the relationship between prey weight and digestion time. 


\section{MATERIALS AND METHODS}

Oëean pout $(40.5-66 \mathrm{~cm})$, Atlantic $\operatorname{cod}(32.5-45 \mathrm{~cm})$, winter flounder (21.5-37.I cm), and Americañ plaice $(16.8-31.8 \mathrm{~cm})$ were collected by otter trawl from Passamaquoddy Bay during April-May 1980. They werre transported to the St. Andrews Biologicaly Station and held in 300-Icircular holding tanks which were supplied with a constant flow of salt water The fish were held at ambient temperature $\left(5-10^{\circ} \mathrm{C}\right)$ and salinities $\cdot(28-31 / 00)^{\prime}$ for a minimum of $3^{\circ}$ wk before being introduced to experimental tanks. They were fed a pelleted diet consisting of squid (26\%), winter flounder (26\%), rock crab (12\%), wherring meal (29\%), herring oil (6\%), vitámin package $(0.75 \%)$, and sodiun carboxymethyl cellulose (0.25\%). Injured fishes or fishes that did not feed were excluded from subsequent experiments. At the beginning of each experiment, two fish of one species were placed in ed'ch of eleven 120-L-circular tanks and kept there for $9 \mathrm{~d}$. A natural photoperiod was adopted" and the water temperature was maintained at $6.25 \pm 0.3^{\circ} \mathrm{C}$ during the experiment. F1shes were given the abovề diet once da1ly (09:00-10.00) and were used experimentally once they fed voluntarily..

On the lst, day of a trial, each fish was fed one or more pellets containing one or more of the following prey species: $\underline{Y}$. sapotilla (BIvalvia, 0.5-2 cm), T. clcada (Amphipoda, 0.5-1.0 cm), and $N$. Inclsa (Polychaeta, 2.0-8.0 cm). Care was taken to incorporate the ențire, uncrushed, prey litem into the pellet. These prey were collected from Passamaquoddy Bay with a 1.3 -m-scallop dredge lined with fine mesh. -The food 1 tems were frozen and stored at $-20^{\circ} \mathrm{C}$. The number of prey placed in each pellef varied as a result of differences in the maximum pellet size

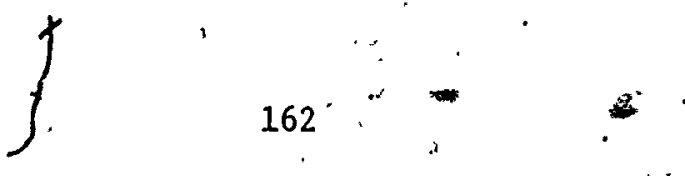


that eâch species could consume. Ocean pout with relatively large mouths could eat large pellets containing three prey specles, whereas winter flounder were fed several smaller pellets containing one or two prey Items. The prey composition of each pellet consumed by each fish was always recorded. Meal size as a percentage of body weight ranged from 0.5 tó 3.3 for ocean pout, 0.96 to 2.14 for cod, 0.66 to 3.10 for pláice, and 0.64 to 3.19 for winter flounder. Five or six fish of each species (92 total) were killed at the follgwing sampling times: $5,12,20$, and 30 $h$ after feeding. The fish remaining after $24 \mathrm{~h}$ were fed prepared food without the prey items, at the normal feeding time.

The alimentary tract was removed from each sampled fish and immediately placed in 5\% Formalin saturated with Borax. Gut contents were exposed and prey. remains were removed within $48 \mathrm{~h}$ of collection The following data were recorded:

(1) position of each prey within the gut (stomach or intestine), (2) condition of each prey using a four-category visual index, (3) prey length for estimating:-initial prey welght:

Prey, remains were placed in aluminum weighing pans and dried to constant, weight at $75^{\circ} \mathrm{C}$.

In a separate experiment, the effect that frozen prey had on digestion rate was determined by feeding pellets containing freshly kflled or live spectimens of $\underline{N}$. Incisa and $\underline{Y}$. sapotilla to ocean pout and cod. The flishes were kilied 5 and $20 \mathrm{~h}$ 1ater. One-way ANOVA was used to test the effect of freezing on the indices of digestion and on the rate of weight loss of the prey with time. Only y- sapotetla found in cod killied at $5 \mathrm{~h}$ showed significantly lower indices of digestion for the fresh as opposed. to the frozen specimen (P 0.05). However, both frozên and unfrozen $\underline{x}$. 
sapotilla could be keyed to species up to $30 \mathrm{~h}$ after feeding. The freezing effect was only significant at the early index categories where recognizability was not a problem. Ocean pout kilied at $20 \mathrm{~h}$ digested the frozen $Y$. sapotilla significantly faster than the fresh ones ( $P<$ 0.05). Previously frozen N. Incisa, fed to the cod killed at $20 \mathrm{~h}$ after feeding and to the ocean pout killed at $5 \mathrm{~h}$ after feeding, also lost - weight significantly faster than did fresh.ones ( $R<0.05$; ANOVA after aresine'transformation of the data). There were no significant differences between the fresh and frozen prey of any of the other elght predator-prey vs. time combinations. Because freezing has a similar but limfted effect on both prey.items tested, we believe that our results are valid.

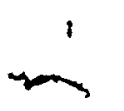

Evacuation rates as described by average. indices of digestion RESULTS as described by average, indices of digestion

Each-category in Table 1 describes a stage in the"digestion of a pecific taxonomic feature which is required to key the animal to' species (Gosner 1971)p Digestion of $N$. incisa followed the same pattern in all predators. Simflarly, the digestion pattern of $\mathrm{T}$. cicada differed among predators only in that the viscera was digested and the appendages became detached earlier in the plaice compared with the other predators. Two digestion patterns occurred for $\underline{x}$ sapot111a. . ocean pout digested the viscera with little damage to the shell. The cleared valves could be seen in the rectum. On the other hand, cod digested the entire shell in the stomach, rarely letting any of it pass to the intestine in a recogni- 
- .

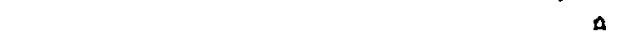

$+$

$+\cdot$
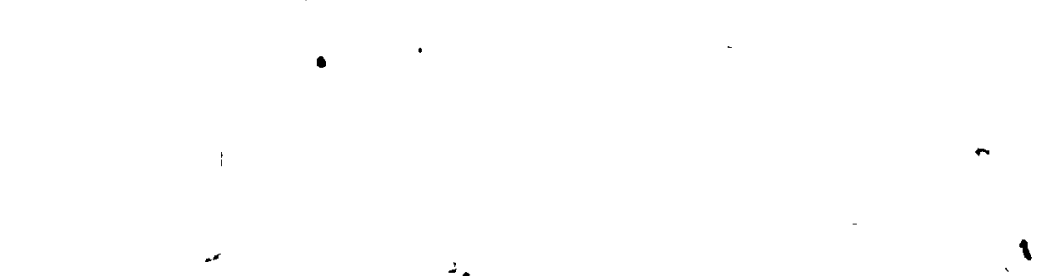

1 


\section{Y. sapot1lla - I. clcada}

Pout, Shell fresh, cod,

flounder,

$\&$ plafce

Pout,

flounder

foot and viscera

undigested,

shell, surface

unscratched

Foot and mantle

digested

Color of body

t and eyes paled

Cod,
plaice

Shell surface

becoming

scratched and

opaque

Pout

Viscera digested

- 8

Cod

.

Foot and mantle

digested

WF

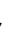

WE

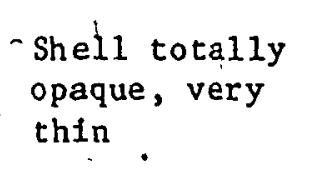

z

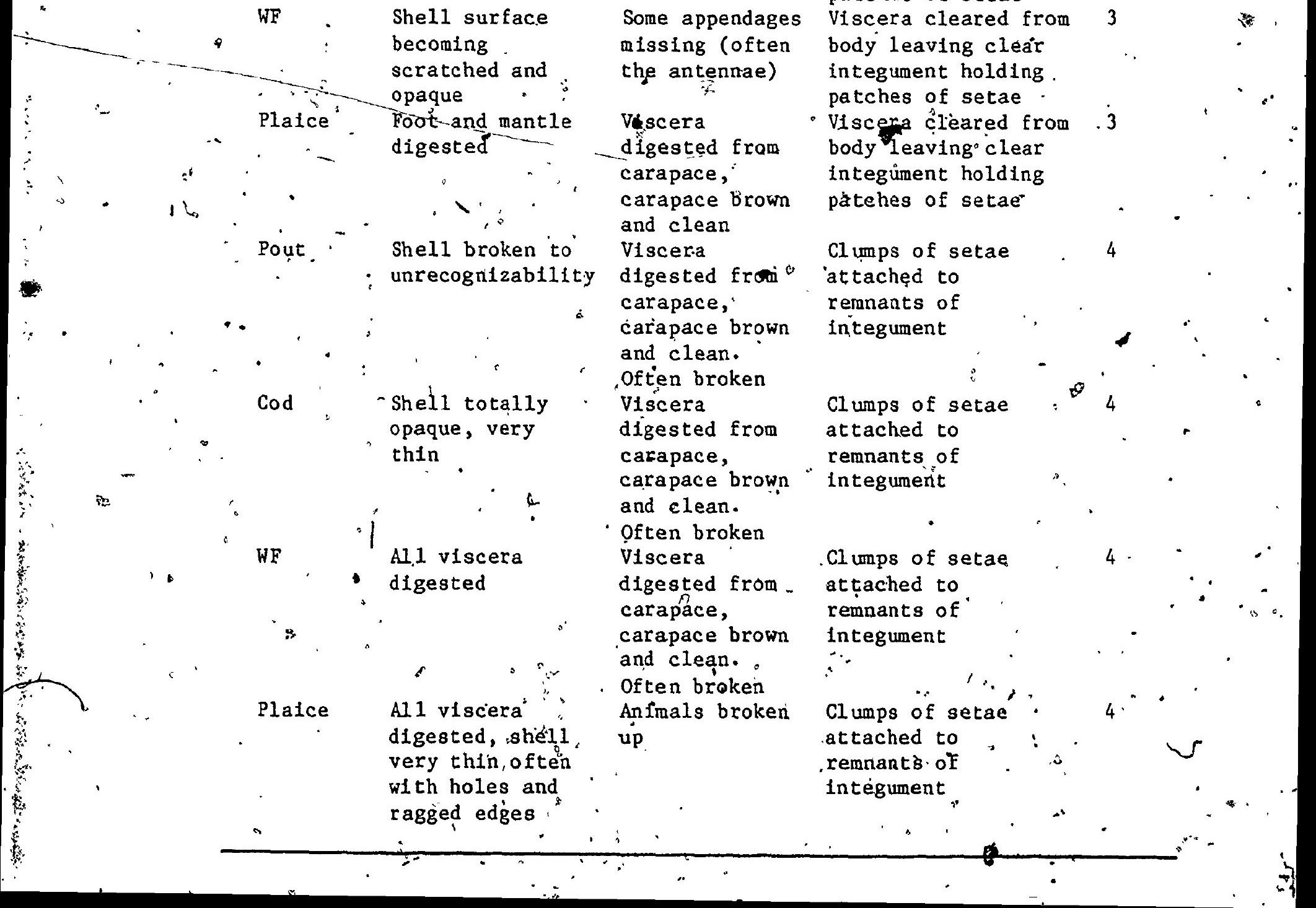

$s$

Platce
Al1 viscera

digested

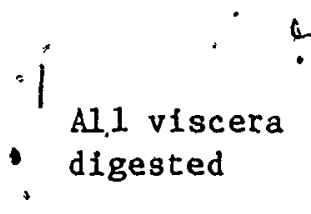

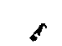

Al 1 visciera: digested, shèll very thin, often with holes and ragged edges
Color of body and eyes paled -

Some appendages missing (often the antennae)

Some appendages missing. (often. the antennae)"

Some appendages missing (often the antennae)

Viscera digested from carapace, carapace brown and clean

Viscera

digested fromi carapace,"

carapace brown and clean. often broken

Viscera digested from carapace, carapace brown and clean.

- Often broken

Viscera digested from. carapace, carapace brown and clean. Often broken Anfmals broken up.

N $\approx$ Incisa

Fresth animal, color and setae distinct

Setae attached to 2 body but not' in. orderly rows disorganized Setae attached to body but not in orderly ,rows disorganized

Viscera cleared from 3 body leaving clear. integument holding: patches of setae Viscera cleared from 3 body leaving clear fintegument holding patches of setae Viscera cleared from 3 body leaving clear integument holding. patches of setae

- Viscera çleared from .3 body leaving ${ }^{\circ}$ clear integưment holding patehes of setae

Clumps of setae attachęd to remnants of integument

Clumps of setae Index No. 1 1

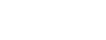




\section{.}

zable state: Digestion of 1 sapotilla by to tinter flounder and platce was. similar to that by cod as it involved the decia of the sentire shell: Howeyer," unlike, the cöd, the "valves were often passed to the intestine before decaying completely.

Thé average index of digestion at each sacrifice time described the progressión towaras unidentiflability of the three prey. species in each of: the four predatoxs (FIg.1). In älofeur predators N. Inclsa was digested most. rapidiy to an unrecognizable state. "This occurred after 20

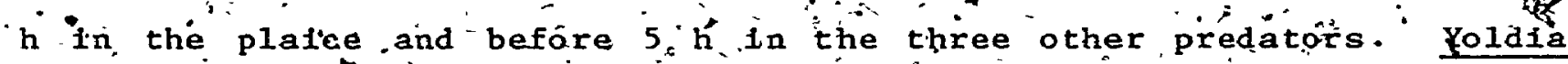
sapattlia was identifiable at least $30 \mathrm{~h}$ after consurptión in all four predators: Thetonyx cicada was digested at an intermediate rate in all

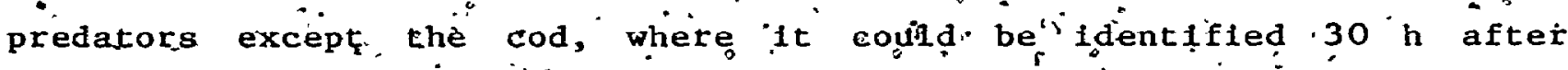
feeding.

The rate of passage of prey from stomach to intestlne varied among predator and prey secies (Fig.i). Alid prey left the ocean poult stomach quickiy and in a relatively, undigested condition. For examie, $50 \%$ (by

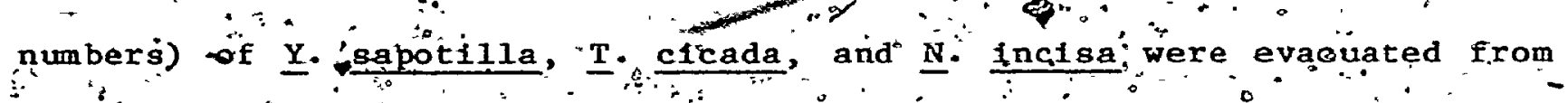
the: stomach othin is, 8, and 7 -h, respeftively correspongto parues were $30^{h}$ for ${ }^{2}$ sapotilla, and $17 \mathrm{~h}$ for $\mathrm{T}$ cicada and N. inclisa." Fod left the stomach of plaice an tinter flounder at a" rate stmilar to that observed for scean pônt with the exception of the

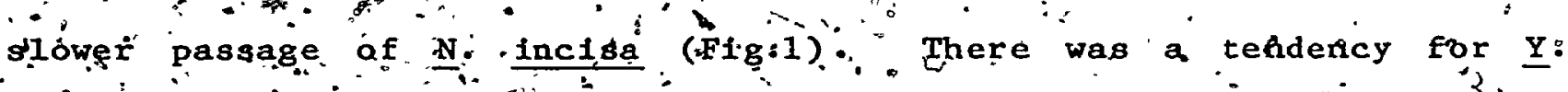
sapptilia to remain d the stomateh longer than the other two prey. Thts was found in all predator out pas most not foeble 1 in tod apdocean pout: (FIg:I):

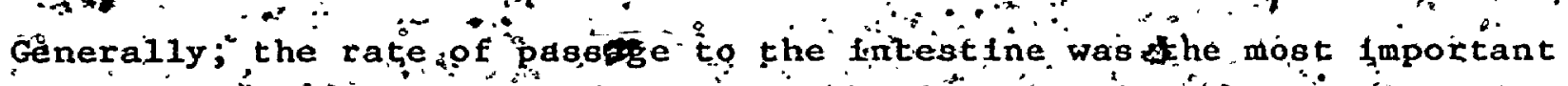

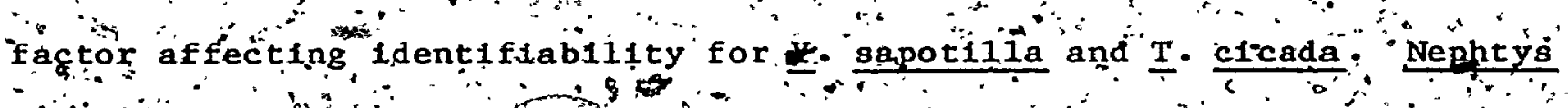
¿á.

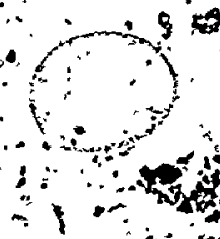




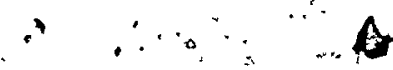

3

A.
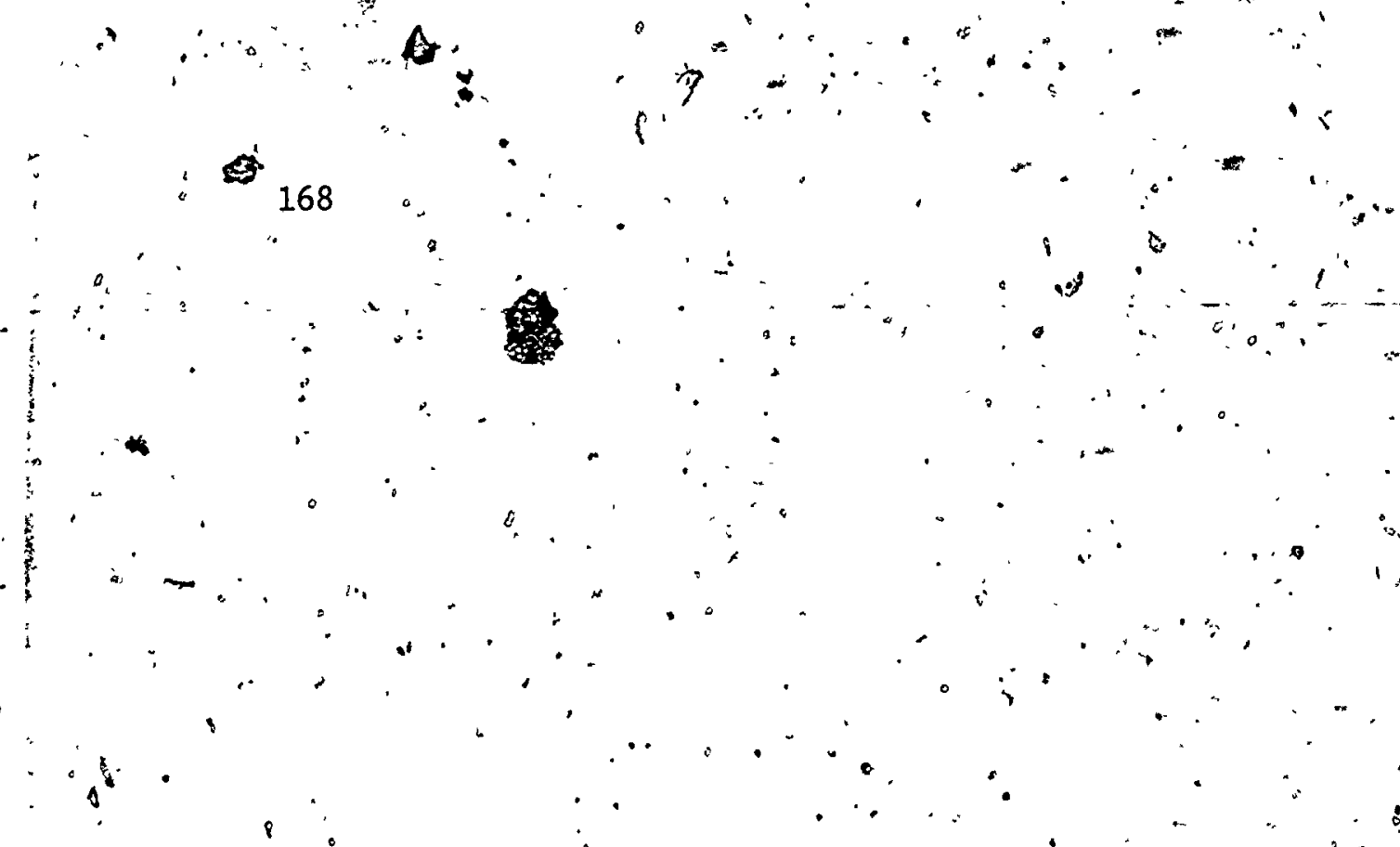

FIGURE: II +1 . Average index of digestion related to time after feeding for reach of the three prey types, digested by êach of the four -predator speciess. The horizontal lines represent the value of the index beyond which Yoldia, Tmetonyx, and. Nephtys, respectively; cannot be identified to "pecies: The vertical lines are the trmes at which $50 \%$ of each prey passes from the stomach to the intestine $-1 \mathrm{n}$ each predator. Numbers in parentheses refer to the numper of prey rẹcovered at each time.
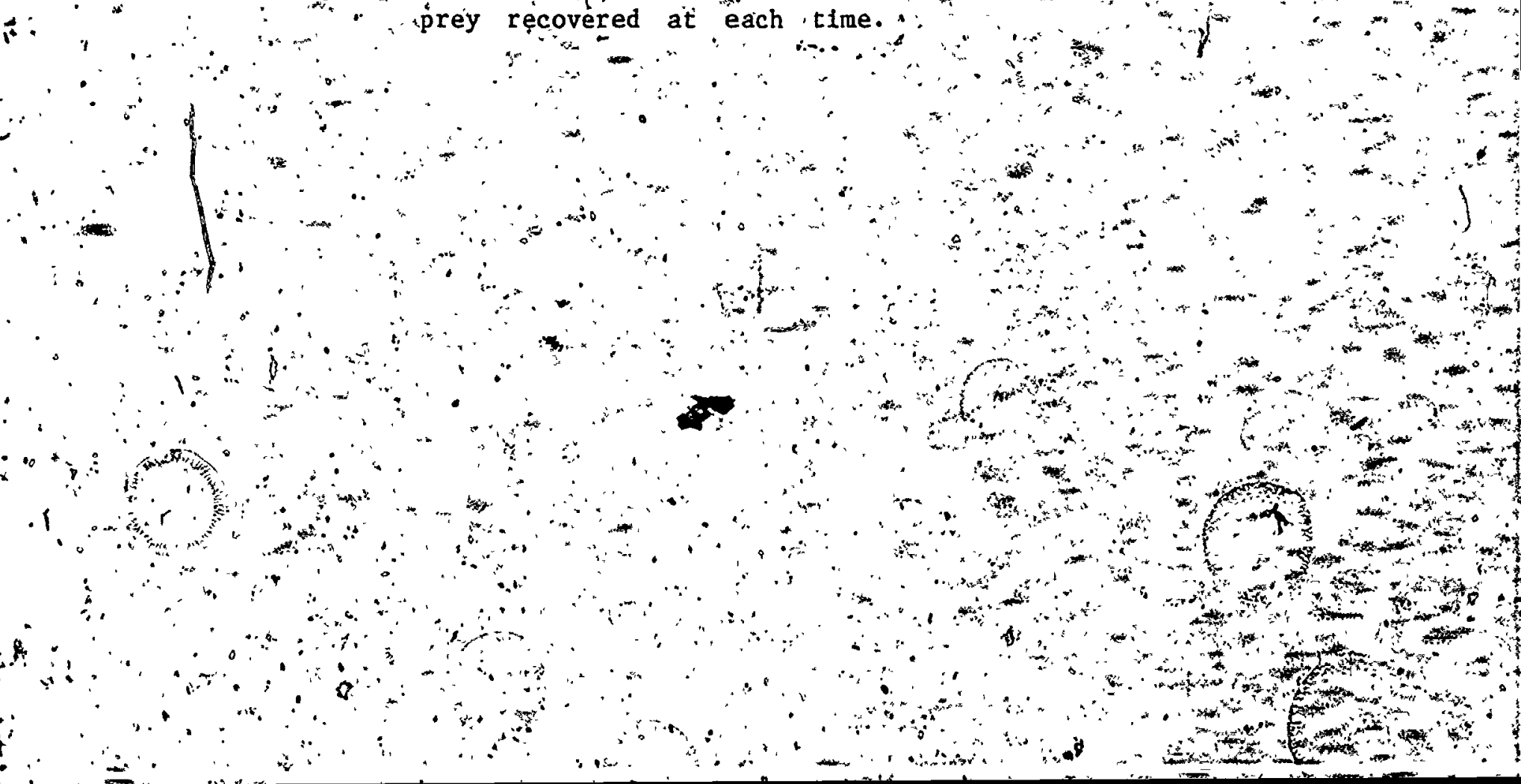


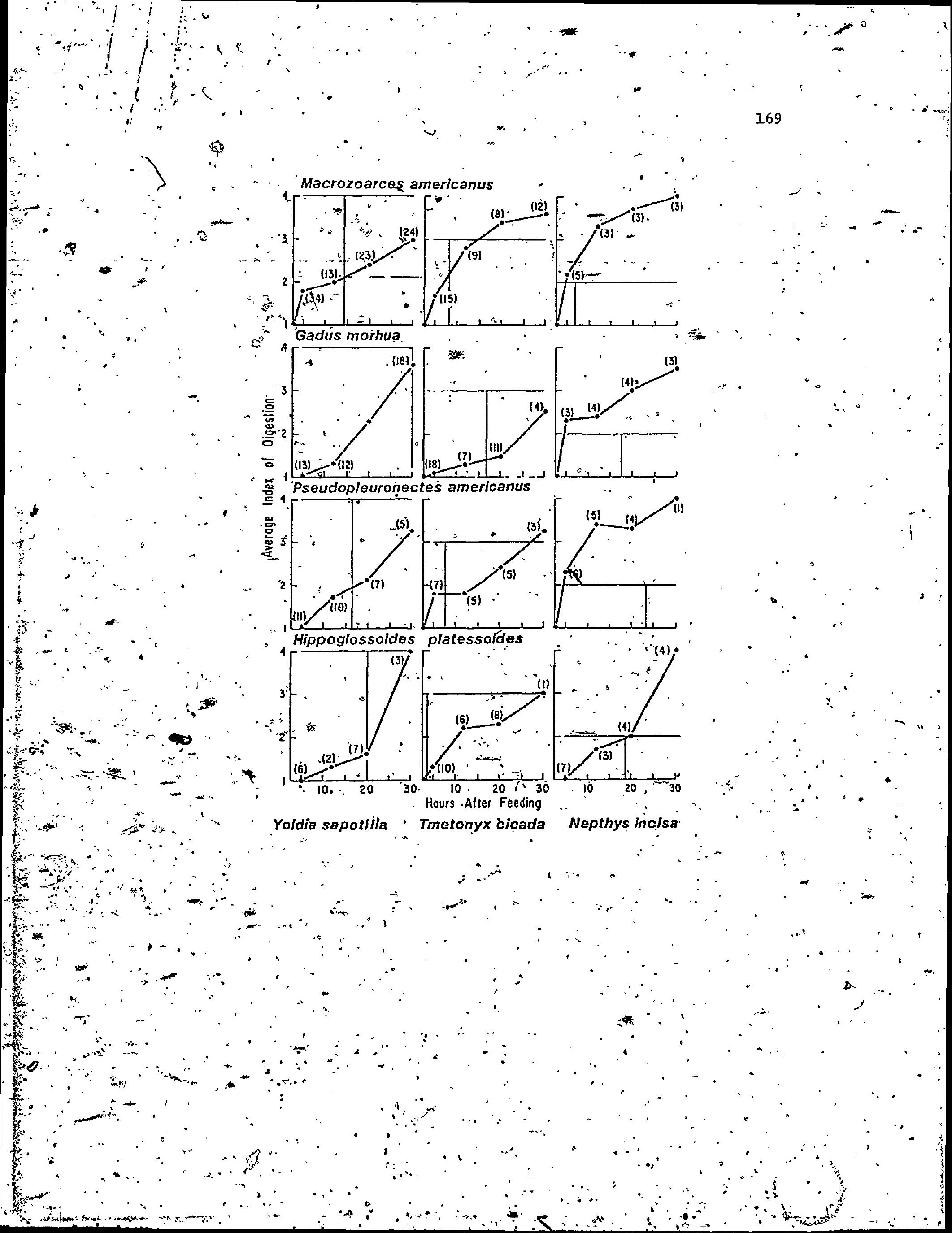




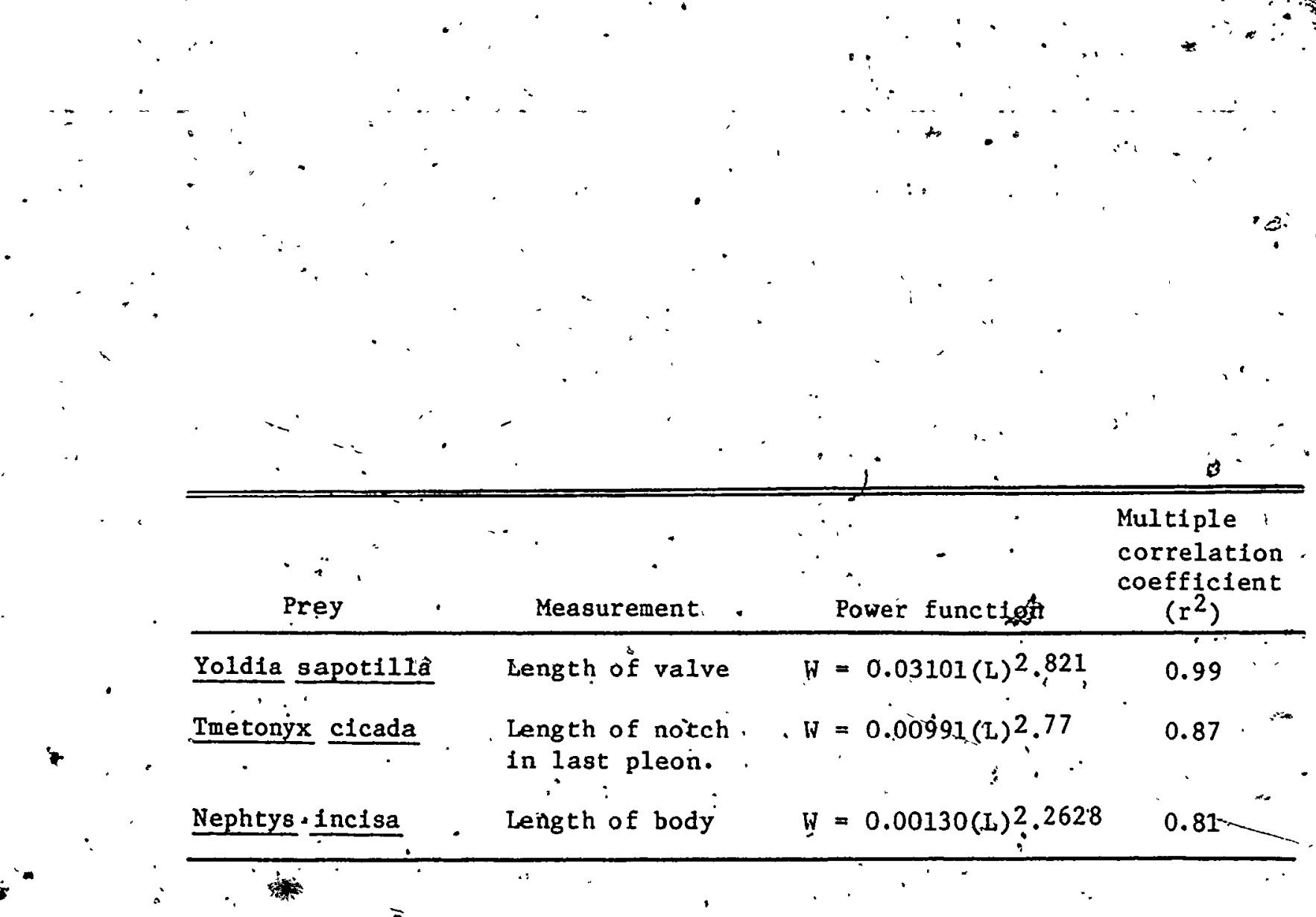

\section{$\therefore$}

\begin{tabular}{|c|c|c|c|}
\hline Yoldia sapotillä & Length of valve & $\mathrm{W}=0.03101(\mathrm{~L})^{2} .821$, & 0.99 \\
\hline Tmetonyx clcada & Length of notch. & $\mathrm{N}=0.00991(\mathrm{~L})^{2} .77$ & 0.87 \\
\hline Nephtys incisa & $\begin{array}{l}\text { in last pleon. } \\
\text { : } \\
\text { Length of body }\end{array}$ & $W=0.00130(L)^{2} .2628$ & $0.81 \cdots$ \\
\hline
\end{tabular}

is. 
173

'. FIGURE II - 2. Relation between percent by weight of prey recovered and time after feeding; for different predator-prey combinations. Lines represent $95 \%$ confidence intervals about the mean. 


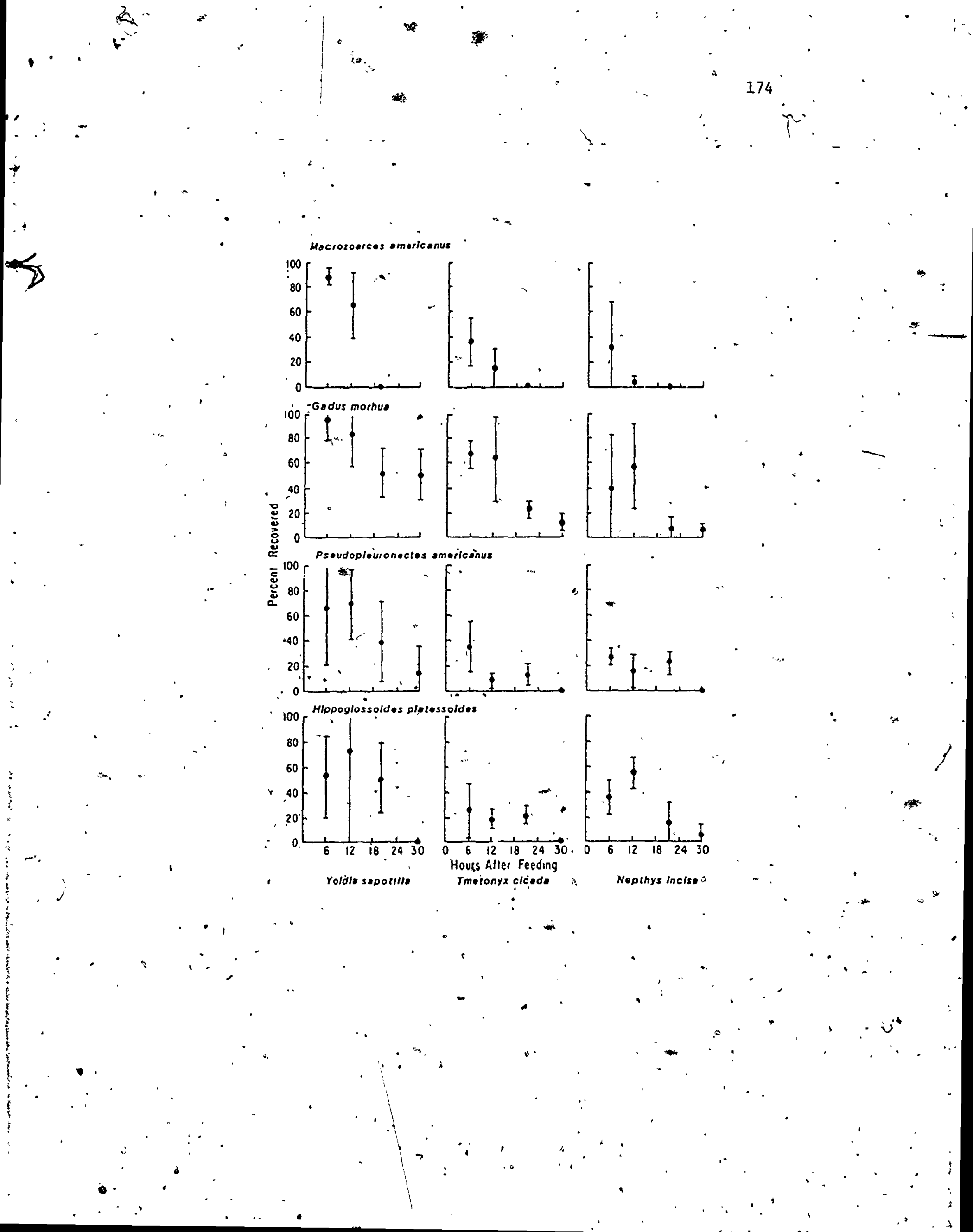




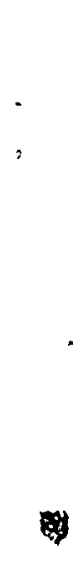

\%
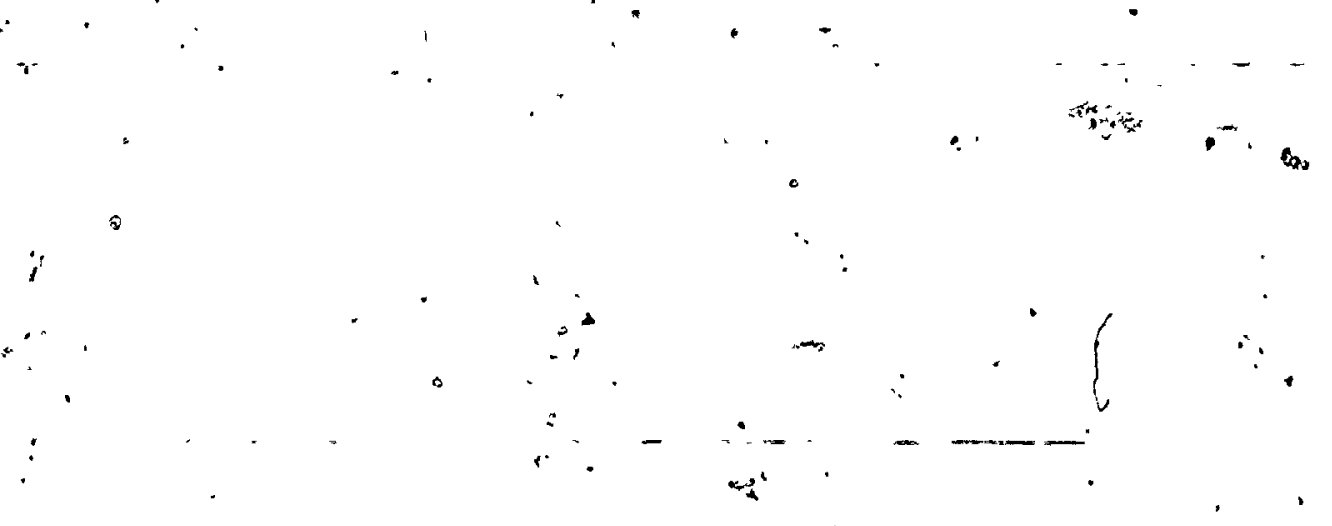


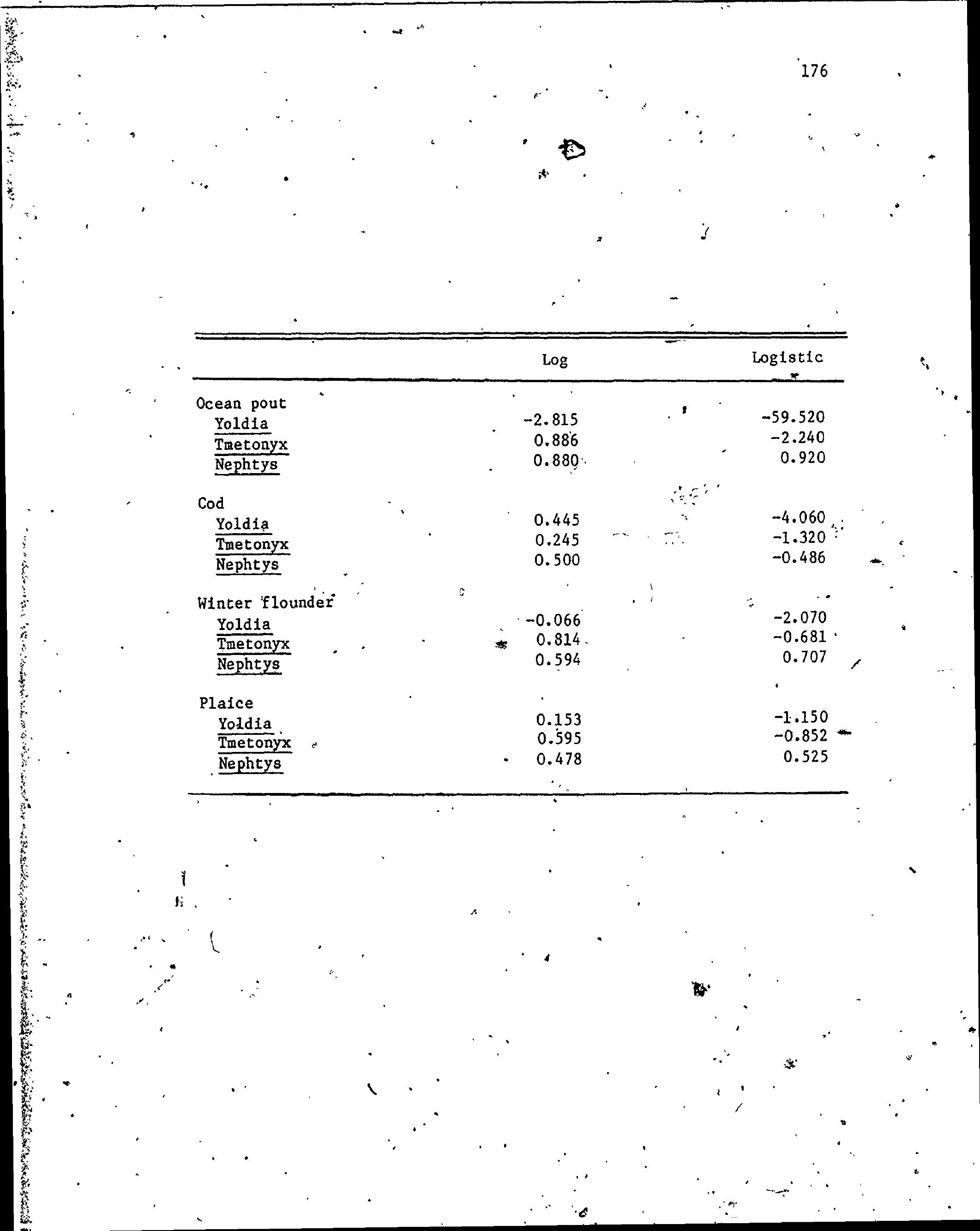


situations the logarithmic model gives a higher $r^{2}$.

The $r^{2}$ values for the data from all predator-prey combinations, for each model, were tested using a paired t-test after they were transformed by the ranking method described by Fisher and Yates (1973). The only significant difference in ftt was between. the logarithmic and logistic models, with the logarithmic model giving the best fit $(P<0.05)$.

The slopes from the logarithmic model fitted to each of the 12 predator-prey evacuation curves (Fig. 3) were compared using a two-way ANOVA. There was no significant predator effect, but there was significant difference between the evacuation rates of $\underline{Y}$. sapotilla and the other two prey species $(P<0.05)$. When slope values of all four predators are combined for each prey, the $95 \%$ confidence 1imits express the difference in evacuation rates between $\underline{Y}$. sapotilla and the combtrín rates of $\frac{N}{\%}$ incisa and $T$. cicada: (Fig. .4).

\section{DISCUSSION}

Evacuation rates as described by average indices of digestion

- 0ceap pout and cod have different patterns of food passage from the stomaeh. These patterns can be related to morphologicail differences in - their alimentary tracts. The heavily muscularized codostomach (Tyler 1973) breaks whole food and digesits it before it is passed to the Intestine. Ocean pout stomachs appear to be, less muscularized and are primarily for storage. Molluskan valves and chitin are partially broken By the flattened pharyngeal teeth, are passed through the pyloric sphincter sooner, and are less digested than in cod." 
FIGURE II - 3. Linear, Iogarithmic, and logistic, models fitted to the data presented trí Fig. 2 (the $\mathrm{r}^{2}$ kalues are given in - Table 3).
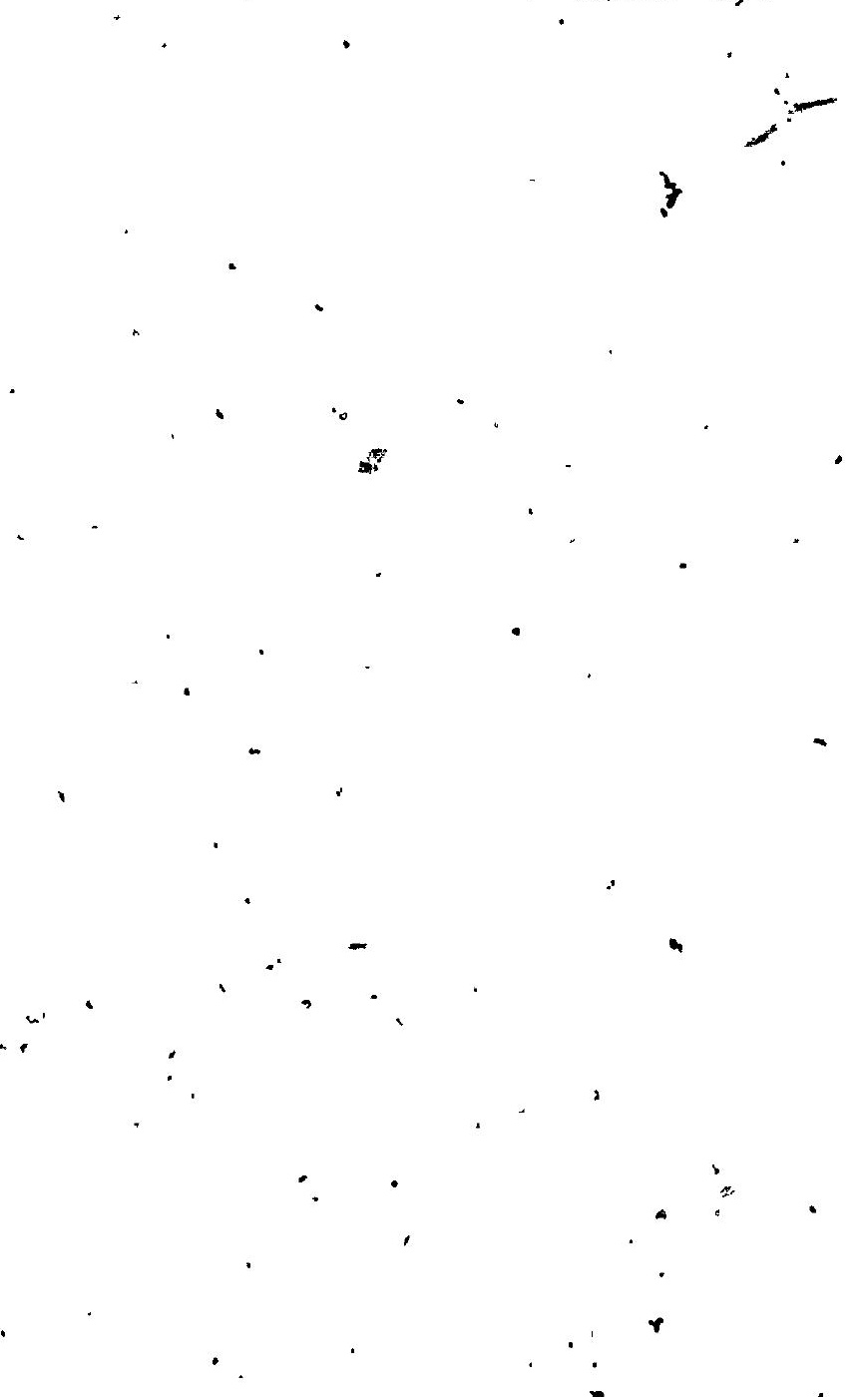

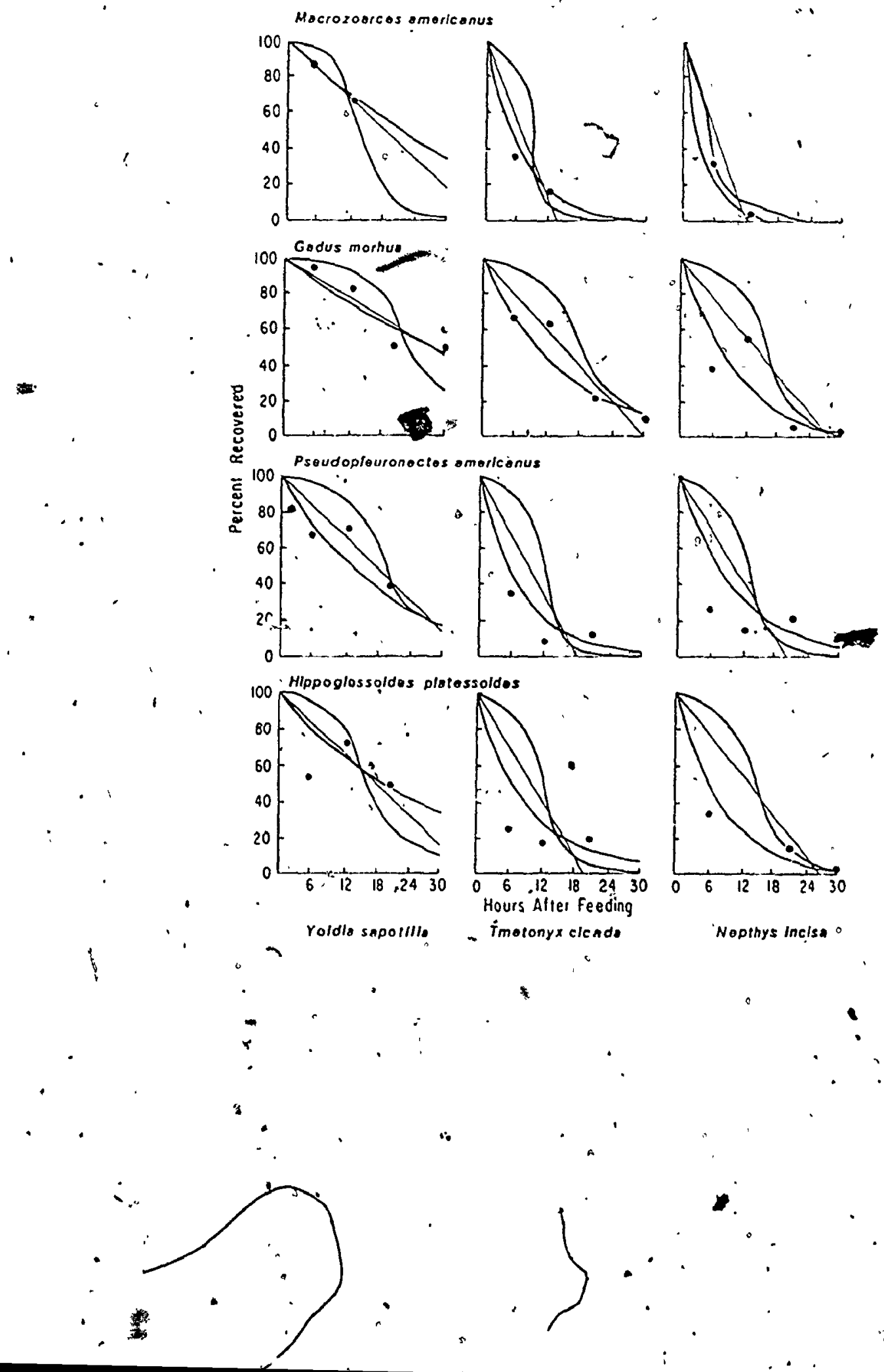

$j$ 


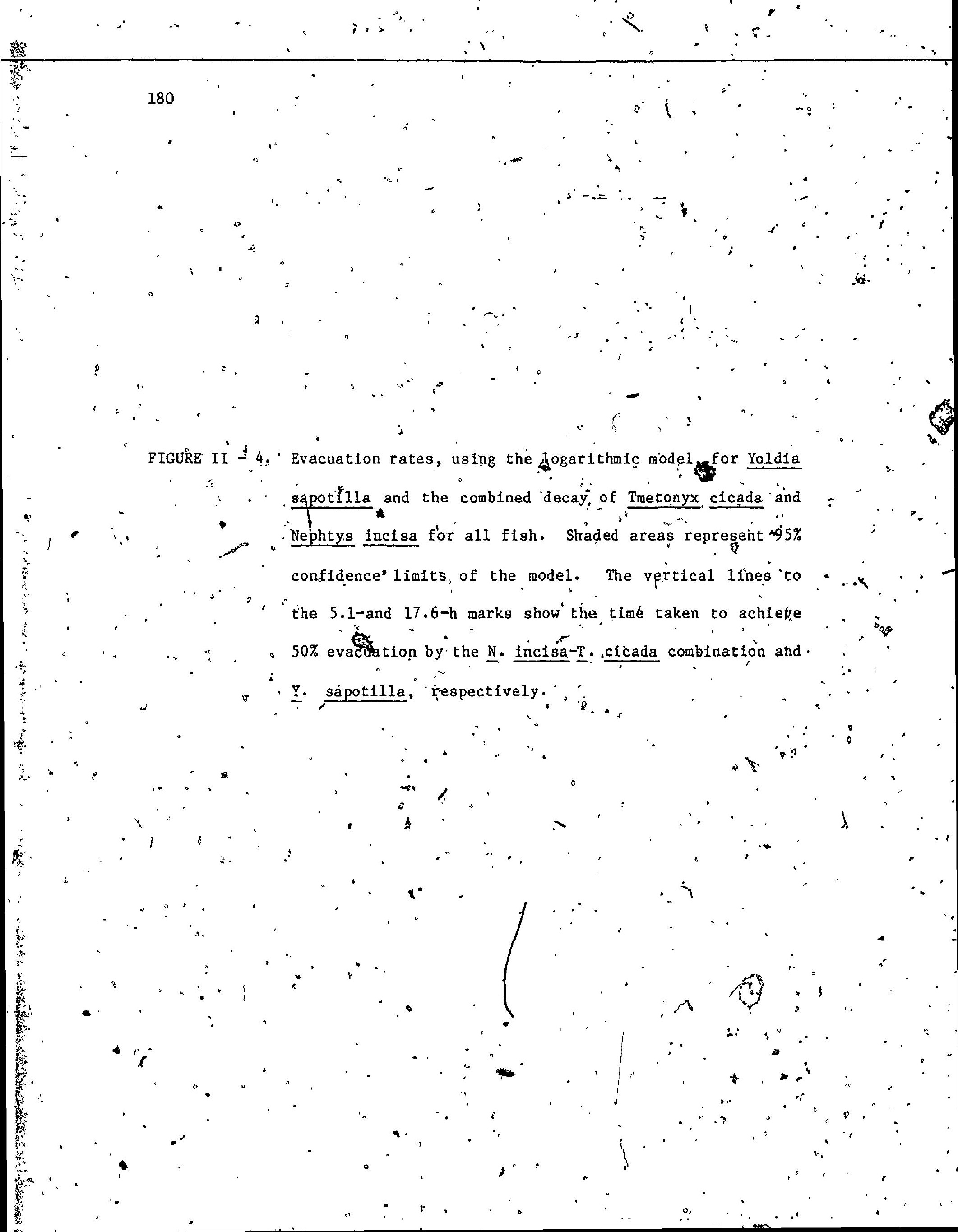




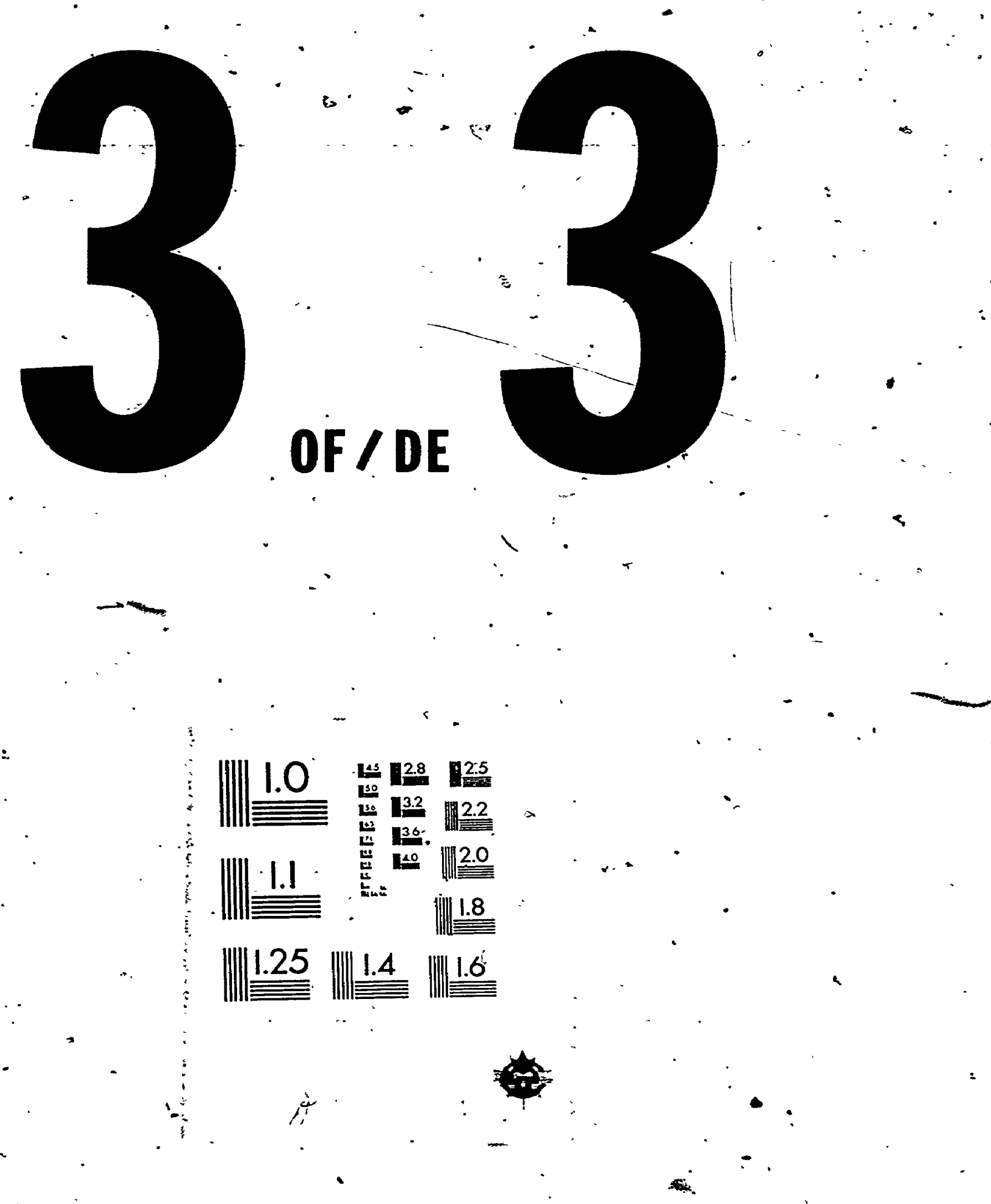



The lafge-diameter intestine of the pout accepts larger and lessdigested objects from the stomach than in the other specles of $f$ ish examined. Experiments with plaice (Edwards 1971), cottids (Western 2971), and trout (Kionka and Windell 1972) suggest that narrow sphincters and intestines restrict the passage of large undigested objects from the stomach. This may also explain why large indigestible objects such as Y. sapotilia were expelled slower than other prey. A shorter, largerdiameter intestine may be an adaptation to retain large food Ionger and to allaw more time for absorption. Longer retention in many herbivores and polychaete feeders results from increased intestine length (DeGroot 1971: Tyler 1973).

Increased absorptive area is achieved with pyloric ceca in the gadids and the pleuronectids. The thickened wall of the pout intestine may act in the same way in the absence of pyloric ceca. If larger objects pass into the pout intestine, pyloric, cêca may be too constrictive to work efficlently:

'Differences in rates of food passage among the four predators accounted for the major differences in decay pattern of the prey. From Inaices of digestion (Table 1 ); rt appears that $\underline{Y}$ - sapotilla valves in cod and pleuronectids were retained in the stomach, having been broken more than those in pout. The stomach is more acldic than the intestine (Wilson 1972; Western 1971) and will digest a shell gifven sufficient time. "Even though the gadids and pleuronectids appear to consume bivalves in nature (Frame 1974; Arntz 1974, 1977), this long retention time may make then a subtoptimal food. Any factor that slows evacuation rates slows food uptake rates and therefore prevents maximum growth (Vahl 1979). Yold1a sapotilla was not reported as a major food itemfor winter 


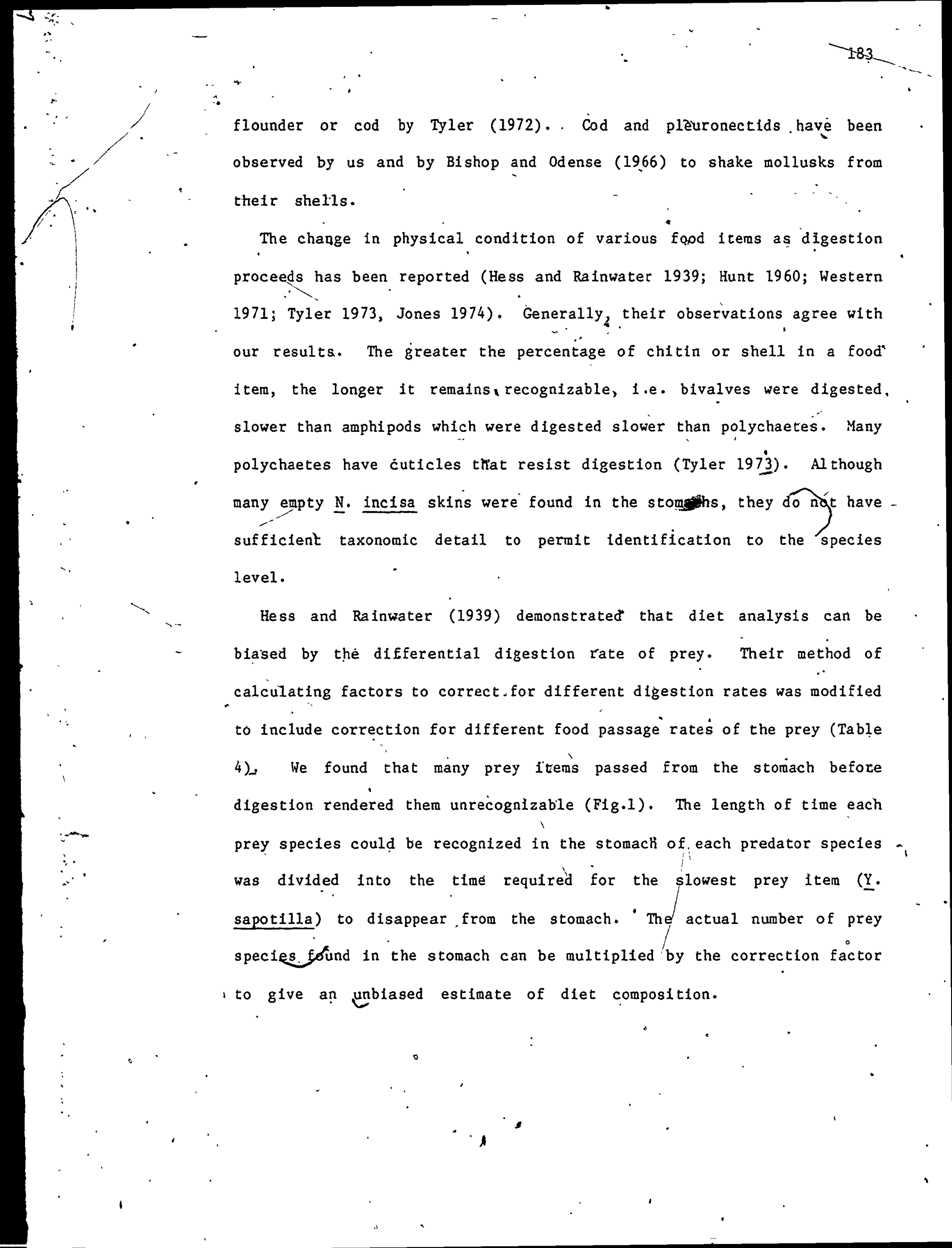


TABLE II - 4. Correction factors for comparing the number of each of the three prey species within a single species of predator based on differential rates of eyacuation or digestion (whichever causes the prey to disappear the fastest). Similarly; values in parentheses compare number of any, one of the prey specles among the four predators. Multiplication of the number of each prey observed in a particular predator's stomach by their correction factors will give comparable values of numbers of each specles of prey eaten between prey species or between predator species. 


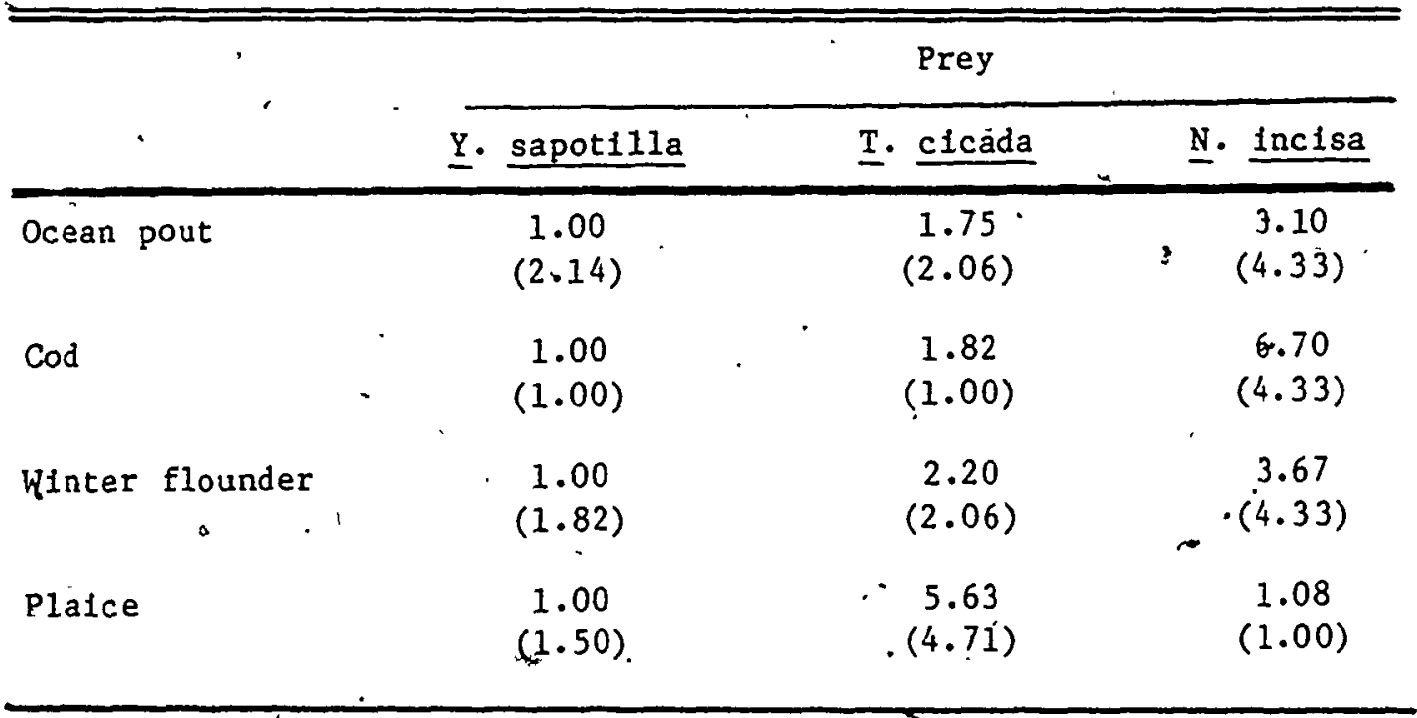


Evacuation rates as described by percentage of original prey welght, lost over" time

Percentage wight loss of food items over time is often used to : * describe digestion and to predict daily rations for fish (reviewed by Elliott and Persson 1978). Some researchers found no difference in depletion rate among different prey (e.g.'Persson (1979) using zooplankton, amphipods, and chironomids; Hindell (1966) using, the naturat prey of Lepomis macrochtrus). Others, such as Jones (1974) using Nergis, Nepthys, and Crangon in cod and haddock, and Kitchell and Windell (968) usling damselfly natads and mealworm larvae in pumpkinseed sunfish, found that prey type did affect rates of food depletion.

Many models have been fitted to evacuation data (Elliott and Persson 1978; Fange and Grove 1979). There is difficulty in choosing the best one because several blologlcal forces shape evacuation rate curves. First, a 'lag occurs when the food enters the stomach ( $\underline{Y}$. sapotilla in ocean pout and cod, Fig. 2). Enzyme reactions are exponential and therefore start slowly (Jennings 1972). In experiments where a

Starvation period precedes the experiment, the digestive fuices are not present when the food enters the stomach (E1llott-1972). The lag time also depends on the resistance of the food's surface and on the ratio of the food's surface area to volume (W1ndell 1967). 'Second, there is a period after the lag time when the digestive rate is maximal. The slope and shape of theje line at thirs point is at least partially controlled by fat content of the food (Quigley and Meschan 1941; Windell 1967). Third, the rate of evacuation will level off at a point determined by the percentage of Indigestible material within the food, e.g. chitin (Battle 
1935). Even when 'data are fitted to linear models, leveling off is often z observed after 80 or $90 \%$ of the material is digested (Fig. 3; Daan 1973). Finaliy, iat has not been considered that food may, enter the intestine before $1 t$ is fully digested. The stomach may act as a holding facility, emptying materifal to the intestine at a constant rate as Intestinal space permits $(e+g \text {. ocean pout })^{\prime}$ Afternatively, the stomach may retain food until it has sufficlently mixed or broken down before passing it to the intèstine $(e . g \cdot \operatorname{cod}):$ " 'One model may not fit all digestive relationships well, given the many fish species and the many foods eaten.

The -linear relation fits as well or better than the other two models when the prey'is composed of al high degree of digestion-resistant material as in Y. sapotilia (Table 3). Despite its inherent ability. to accommodate lag time, a steep rate of descent, and a leveling off with. time, the logistic curve poorly described the gastric process; in some cases, lag times were not long enough and food items did not decay close enough to $0 \%$ to accepts such a model (Fig. 3, Table 3). The gmpnential curve seemed to give a good fit for the faster digesting prey pherp there. was. less delay in commencement of digestion when the food entered the stomach (Table 3). For this reason, it successfully fitted data.where, prepared food or dissécted natural food was used (ryler 1970; Elilott ○ 1972; Jones 1974). Cutting natural food, such as shrimp or fish, exposes the centre of the food to the action of digestive enzymes and could potentially. Ancrease the rate of digestrog.

The results of the visual index and weight loss over time methods of evaluating digestion time partially support each other. The visual method Indicates differences, between all prey and sbine predators. The 

ग

We are grateful to many of the staff at the St. Andrews ${ }^{2}$ Biological Station and the Huntsman Marine Laboratory, Including Dr. M.J. Dadswell - and Mr. R. Gowan for their assistance during tits study. Thank also go to Dr. D. Ankney and Dr. R.W. Langton for their critical review of this כ paper. $\bar{M}$. R. Garnett made numerous suggestions to improve the manuscript. Messes. W. McMulion and C.F. Cunningham prepared the figures. The work done by J.S. Macdonald was in partial fulfillment of Ph.D. studies supported by NSERC operating and strategic grants to R.H. Green. 


\section{REFERENCES}

ARNTZ, W.E. 1974. A contribution to the feeding ecolog gof juventle cod (Gadus morhute.) in the western Baltic. Rapp. P. -V. Reun. Cons. Int. Explor. Mer 166:13-19.

1977. Predation on benthos by founders, Platichthys fesus (L.) in the deeper parts of Kiel Bay. Kiel. Meeresforsch. 26 (1977/78): 7078. (Publ. No. 197 of Joint Research Programine Interaction Sea-Sea Bottom (SFB95) of Kiel University)

BATTLE, H.I. 1935. Digestion and digestive enzymes in the herring (Clupea harengus . L.). J. Biol. Bo ard Can. 1:145-157. BERG, J. 1979. Discyssion of methods of investigating the food of fishes, with, reference to a preliminary study of the prey of Godbiusculus favescens (Gobildae). Mar. Biol. 50:263-273.

BISHOP, C., AND P.H. ODENSE. 1966. Morphology of the digestive tract of cod, Gadus morhua. J. Fish. Res. Board Can. 23: 1607-1615.

CAILLIET, G.M. 1976. Several approaches to the feeding ecology of fishes, p.1-14. In C.A. Simenstad and, S.J. Lipoysky [ed.] Fish food hablt studies, 1st- Pacific Northwest Technical Workshop, University of Washington, WA.

CONOVER, R.J. 1978. Transformation of organic matter, p.221-499. In 0. Kinne [ed.] Marine Ecology, Vol.IV, Dynamics. John Wiley \& Sons, Inc., New York, NY.'

DAAN, N. 1973. A quantitative analysis of the" food intake of North Sea cod, Gadus morhua. Neth. J. Sea. Res. 6:479-517.

DEGROOT, S.J. 1971. On the interrelationships between morphology of the alimentary tract. Food and feeding behaviour in flatfishes (Pisces: 
Pleuronectiformes). Neth. J. Sea Res. 5:121-196.

EDWARDS, D.J. 197i. Effect of temperature on rate of passage of food. through the alfmentary canal of the plaice Pleuronectes platessa. J. Fish. Biol. 3:433-439.

ELLIOTT, J.M. 1972. Rates of gastric evacuation'in brown trout. Salmo trutta L. Freshw. Biol. 2:1-18.

ELLTOTT, J.M., AND.L. PERSSON. 1978. The estimation of dally rates of food consumption for fish. J. Anim. Ecol. 47:977-991.

FANGE, R., AND D. GROVE. 1979. Digestion, p.161-260. In W.S. Hoar, D.J. Randall, and J.R. Bried [ed.]'Fish. Bioenergetics and growth. Academic Press, New York, NY.

FISHER, R.A., AND F. YATES. 1973. Statistical tables for biological agricultural and medical research ( 6 th ed.). Olfver and Boyd, Edinburgh. $112 \mathrm{p}$.

FRAME, D.W. 1974. Feeding, habits of young winter flounder (Pseudopleuronectes americanus): prey avallability and diversity. Trans. Am\& Fish. Soc. 2:261-269.

GAARE, E., A. SORENSON, AND R.G. WHITE.- 1977. Are ramen samples representative of the diet? 0ikos 29:390-395.

GOSNER, K.L. 1971. Gulde to identification of marine and estuarine invertebrates. Wiley-Interscience, Toronto, Ont. 693 p. HESS, A.D., AND J.H. RAINWATER. 1939. A method for measuring the food preference of trout.' Copela $3: 154-157$. HUNT, B.P. 1960. Digestion rate and food consumption of Florida gar, warmouth and largemouth bass. Trans. Am. Fish. So c. 89:206-211. JENNINGS, J. B. 1972. Feeding, digestion and assimilation in animals (2nd ed.). Pergamon Press, London. 244 p. 
JONES, R. 1974. The rate of elimination of food from the stomachs of haddock Melanogrammūs aeglefinus, cod Gadus morhua and, whiting Merlangius merlangus. J. Cons. Int. Explor. Mer 35:225-243.

KIONKA, B.C., AND J.T. HINDELL. 1972. . Differential movement of digestible and 'indigestible food fractions in rainbow trout, Salmo gairdneri. Trans. Am. Fish.' Soc. 1:112-115.

KITCHELL, J.F., AND J.T. WINDELL. 1968. Rate of gastric digestion in gumpkinseed sunfish, Lepomis gibbosus. Trans. Am. Fish. Soc. 97:489492.

PERSSON, L. 1979. The effects of temperature and different food organisms on the rate of gastric evacuation in perch (Perck fluvatilis):' Freshw. Biol. 9:99-104.

QUIGLEY, J.P., AND I. MESCHAN. 1941. Inhibition of the pyloric sphincter region by the digestive products of fat. Am. J. Physiol. 134: 803807.

TYLER, A.V. 1970. Rates of gastric emptying in young cod. J. Fish. Res. Board Can. 27:1177-1189.

TYLER, A.V. 1972. Food resource division among northern, marine, demersal fishes. J. Fish. Res. Board Can. 29:997-1003.

TYLER, A.V. 1973. Alimentary tract worphology of selected north Atlantic fishes in relation to food habits. Fish. Res. Board Can. Tech. Rep. $361: 23$ p.

VAHL, 0. 1979. An hypothesis on the control of food intake in fish. Aquaculture 17:221-229.

WESTERN, J.R.H. 197i. Feeding and digestion in two cottid fishes, the freshwater Cottus gobio L. and the marlne Enophrys bubalis (Eurphrasen). J. Fish. Biol. 3:225-246. 
WILSON, J.A. 1972. Principles of animal physiology. MacMillan Rubl.Co., New York, NY. 842 p.

WINDELL, J.T. 1966. Rate of digestion in the bluegill sunfish. Invest. Indiana Lakes i streams 7:185-214.

WINDELL, J.T. 1967. Rates of digestion in fishes, p.151-173. In S.B.' Gerking [ed.]. The Biological basis of freshwater fish production.

- John Wiley \& Sons, Inc., New York. NY.

WINDELL, J.T. 1978. Method for assessment of fish production in L freshwater, p. 227-254. . In T. Bagel [ed.] Estimating food consumption. 'ard ed. Blackwell scientific Publications, Oxford: 


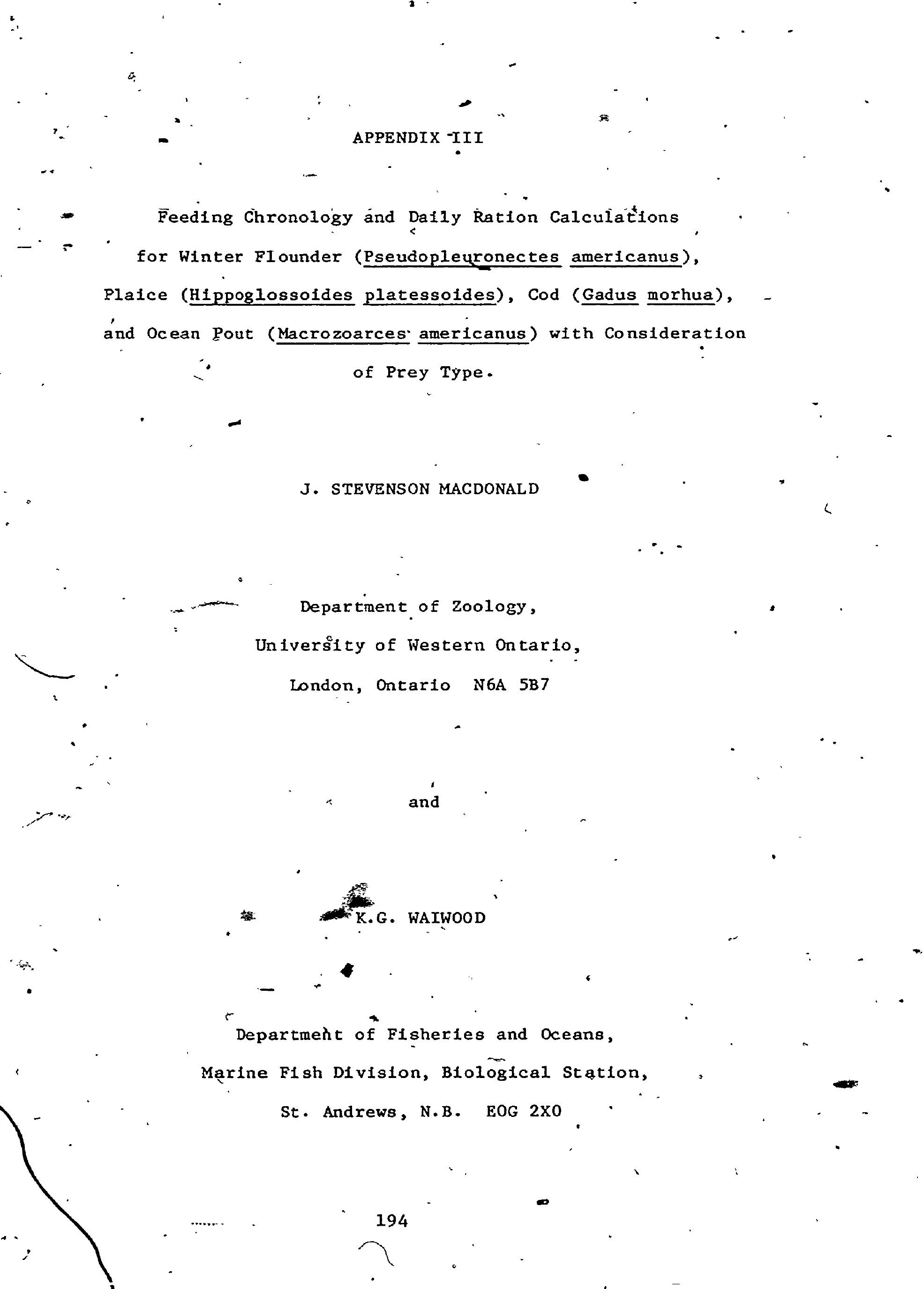


Several regearchers have emphasized the importance of feeding chronology (time of dafly feeding activity) and dafly ration studies in the examination of interspecific competition and predator-prey Interaction studies (Darnell and Meierotto 1962; Keast and Welsh, 1968; Doble and E'ggers 1979). Recently there has been increased interest in dally feeding times, and ration of porthwest Atlantic fishes.

Feeding chronology of winter flounder was observed by 01 la et al (1969), winter flounder and cod by Hacunda (1980), and ocean pout by Edwards and Bowman (1979). Unfortunately, few statistical techniques have been used to analyze feeding periodicity data and it has never been expressed in terms of ration (amount consumed corrected for amount evacuated).

Ration estimates of haddock have been made by Jones $(1978)$, and of winter flounder by Tyler and. Dunn (1976) and Huebner and Langton (1982). in laboratory studies. Daily rations have not be calculated for any other northwestern Atlantic fishes. Estimates have not considered the evacuation rate differences that occur among prey types (Macdonald et al 1982). The daily ration of slow evacuating prey (eg. bivalves) wili be over estimated and the ration of fast evacuating prey (eg. poloychaetes and amphipods) will be under estimated. If the evacuation rates do not differ among all predator species considered in the study (as is the case in this study) rations calculated for predators that consume a large portion af slow evacuating prey will be over estimated.

This field study investigates the feeding chronology of 4 syntopic species of demersal fish (ocean pout - Macrozoarces americanus, winter 
flounder - Pseudopleuronectes americanus, American plaice Hippoglossoldes platessoldes and cod - Gadus morhua) using 3 methòds. a) Mean volume of food found in the stomachs of each species of fish collected at 4 times during a $24 \mathrm{~h}$ day are compared using analysis of covariance (ANCOVA) where total fish lengths was the covariate. b) Estimates of food volume consumed between each collection time are made using Elliott and Persson's (1978) ration model with evacuation. rates that are specific to prey type. c) Visual indices of digested prey condition (Macdonald et al 1982) are used to estimate the numbers of common prey species eaten during the sampling period. The last 2 methods also provide estlmates of daily ration. The two ration estimates are compared by converting number of prey of each collection interval to volume of prey using estimates of average prey welght in the predator's stomachs, from unpublished data.

\section{. MATERIALS AND METHODS}

The study was carried out in Passamaquoddy Bay, N.B., based on one 24h period of otter trawling on May 15, 1981. The study site was 30 fathoms (56 m) deep and had a bottom temperature during the coilection period of $5.8 \pm 0.3^{\circ} \mathrm{C}$. Four half-hour tows were made at 5 to 7 .h intervals at 1:00, 7:00, 14:00, and 20:00. There was no evidence of regurgitation of stomach contents during the collection.

Since fish size has an effect on food uptake raties and on rates of gastric evacuation, collections of each species were restricted to the commonest size class. The total lengths, mean welghts and sample sizes were: ocean pout (Macrozoarces americanus) 42-56 cm, $560 \mathrm{gms}, \mathrm{n}=36$; 
winter flounder (Pseudopleuronectes americanus) $27-3 \dot{4} \mathrm{~cm}, 370^{\circ} \mathrm{gms}, \mathrm{n}=$ 40; American plaice (Hippoglossoides platessoldes) 14-31 cm, $90 \mathrm{gms}, \mathrm{n}=$ 25; cod (Gadus morhua) $16-27 \mathrm{~cm}, 100$ gms, $\mathrm{n}=` 25$.

On the boat, the fish were measured, weighed and their stomachs and intestines were preserved separately in numbered jars of $10 \%$ formalin saturated with borax. Gut contents were exposed and prey remains were removed within $48 \mathrm{~h}$ of collection. The following data were recorded: 1) volume of stomach contents, including mucús and all prey remains were measured as water displaced in a graduated cylinder after excess water was blotted from sample (empty stomachs were included when estimating mean volume of stomach contents); 2) prey were identified to the lowest possible-taxonomic level; 3) condition of most prey items in the stomachs and intestines were noted using a four category visual index proposed by Macdonald et al (1982).

Times of daily peak feeding activity were expressed in three ways. Numbers of common prey items eaten during each collection time were estimated using indices, of diggestion. The indices describe stages in the digestion of specterc taxonomic features which are required' to key prey to species. At temperatures close to $5.5^{\circ} \mathrm{C}$, an index value can be used to estimate the length of time each prey item has been in the stomach and thus the time of day it was consumed. The indices were calculated for Yoldia sapotilla (BIvalvia), Nephtys Inctsa (Polychaeta), and all species of amphipods:. This assumes all amphipod spectes follow the digestion patterns described by Macdonald et al (1982) for Tmetonyx clcada. The bivalves consisted of $98 \% \underline{Y}$. sapotilla, the polychaetes $60 \% \underline{N}$. incisa. Ninety-seven percent of the total diet of all fish was described by Indices. 
A-second estimate of feeding periodicity was made by plotting mean food volume consumed during each sampling interval by each predator spęciés vs time of day. A two-way ANCOVA was used to examine the consumption of food with respect to predatom species and time effects controlling for the covariate fish length. In this way, variation in volume due to larger fish having larger stomachs was examined and corrected. Tests for interaction between main effects investigate the hypothesis that fish species feed at different times of day. When significant interaction occurs, main effects can only be tested by partioning the data matrix by predator species and aping four one-way ANCOVA's. Data were analysed using the MANOVA procedure in sPSS on the University of Western Ontario's CYBER 170.

- The third estimate of feeding periodicity involved the calculation of volume of food consumed over each collection interval after the food evacuation rate is taken into consideration (food ration). Food evacuation in the stomach of the four species of fish was described by an exponential decay function with a rate $(R)$ of -0.03865 for bivalves and -0.1346 for the combined rates of amphipods and polychaetes (Macdonald, unpublished data; for the same fish and prey species used by Macdonald et al' (1982) found no significant evacuation rate differences. among. predators or between amphipods and polychaeles). The mean of the two rates agrees closely with the winter flounder evacuation rates described by Huebner (1982). Huebner's study used a diet of squid and was carried out at approximately the same temperature. When evacuation occurs exponentially and feeding is constant, the best model to calculate the volume $\left(\dot{C}_{t}\right)$ of each of the two prey categories consumed over a given time (t) is described as: $\left.C_{t}=\left(S_{t}-S_{0} e^{-R t}\right)\right) R^{\prime} t / 1-e^{-R t}$ by Eggers.(1977), 
Elllott and Persson (1978), Cöchran (1979), and Jobling (1981). S and $S$

$\because$ are mean relative stomach volumes at the end and beginning of the interval between catches. The equation corrects for food volume loss due to digestion. Estimates were made for the two prey categories over each of the four sampling intervals for each predator species.

Dally ration estimates for each predator specles were cal fulated by combining volumes of each prey type eaten at each sampling interval. They are expressed as volume per fish per day and as volume as a percent of body weight per day. Estimates of volume of food consumed calculated in thlis manner (Vol/fish/day) were compared to estimates of number of prey consumed daily after numbers were converted to volumes by multiplying by the average weight of each prey species. Volume estimates (\% body wt/day) were also compared to welght estimates of winter flounder - daily ration made by Tyler and Dunn (1976) and Huebner and Langton (1982)

\section{RESULTS}

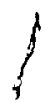

Thiere are differences in the time of day each fish species consumes :-

the maximum volume of food (significant fish species $x$ time interactions

T $\mathrm{P}<0.05)$. Three of the predators contalned maximum food volumes in early evening $\left(20: 00\right.$ - Figure $1 ; \quad \dot{P}<0.05^{\circ}$ after partitioning by $\dot{f}$ ish species to do four one-way.ANOVAs). A fourth predator, cod, displays no significant feeding periodicity ( $P>0.05)$. The perfod of most intense feeding, occurs between 7:00 and 14:00 for winter flounder and ocean pout. This is the period when ration (volume corrected for evacuation rate) 1s highest (Fig; 2). Plaice tended to have a higher ration later in the day. The winter flounder was the only predatór specles to show 



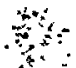

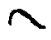

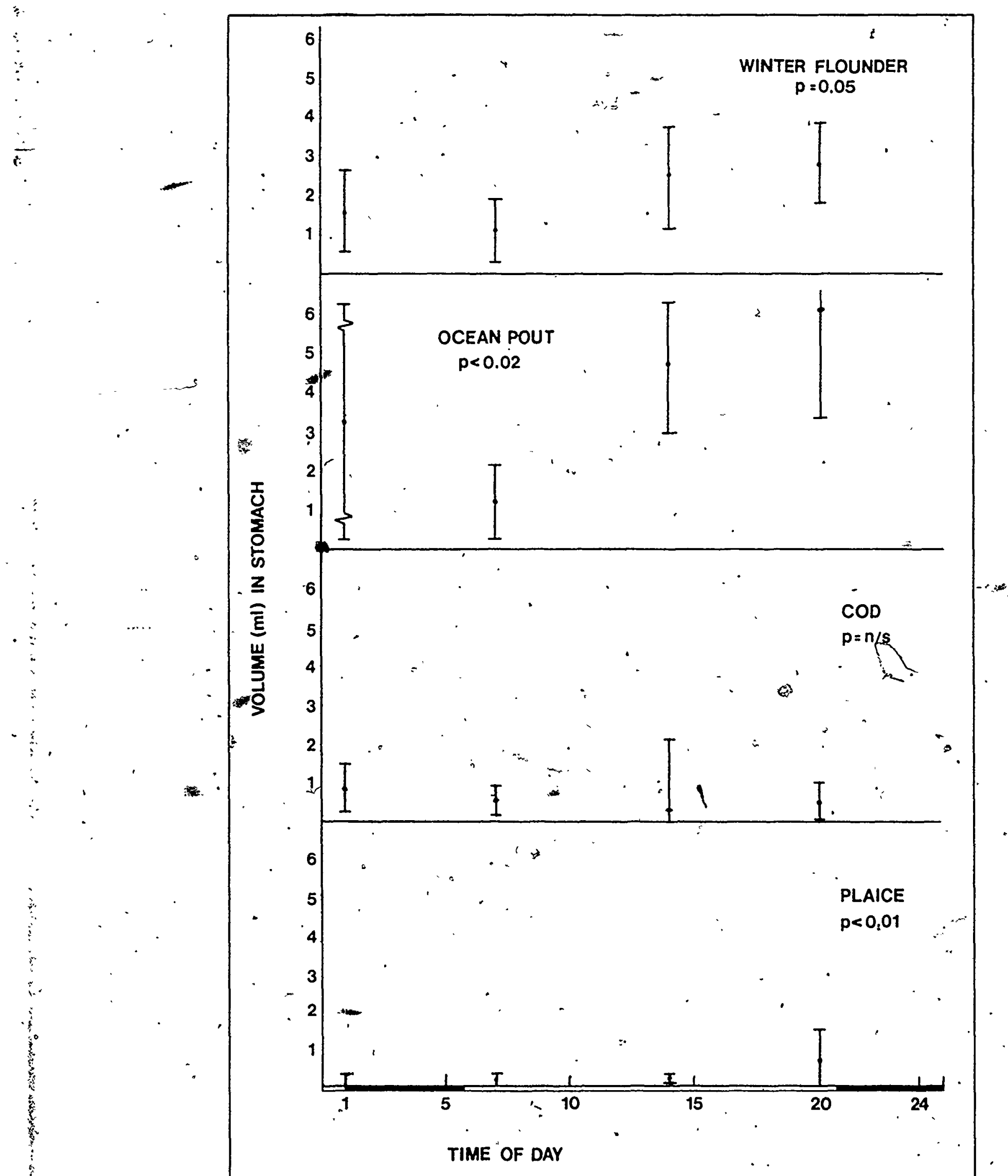



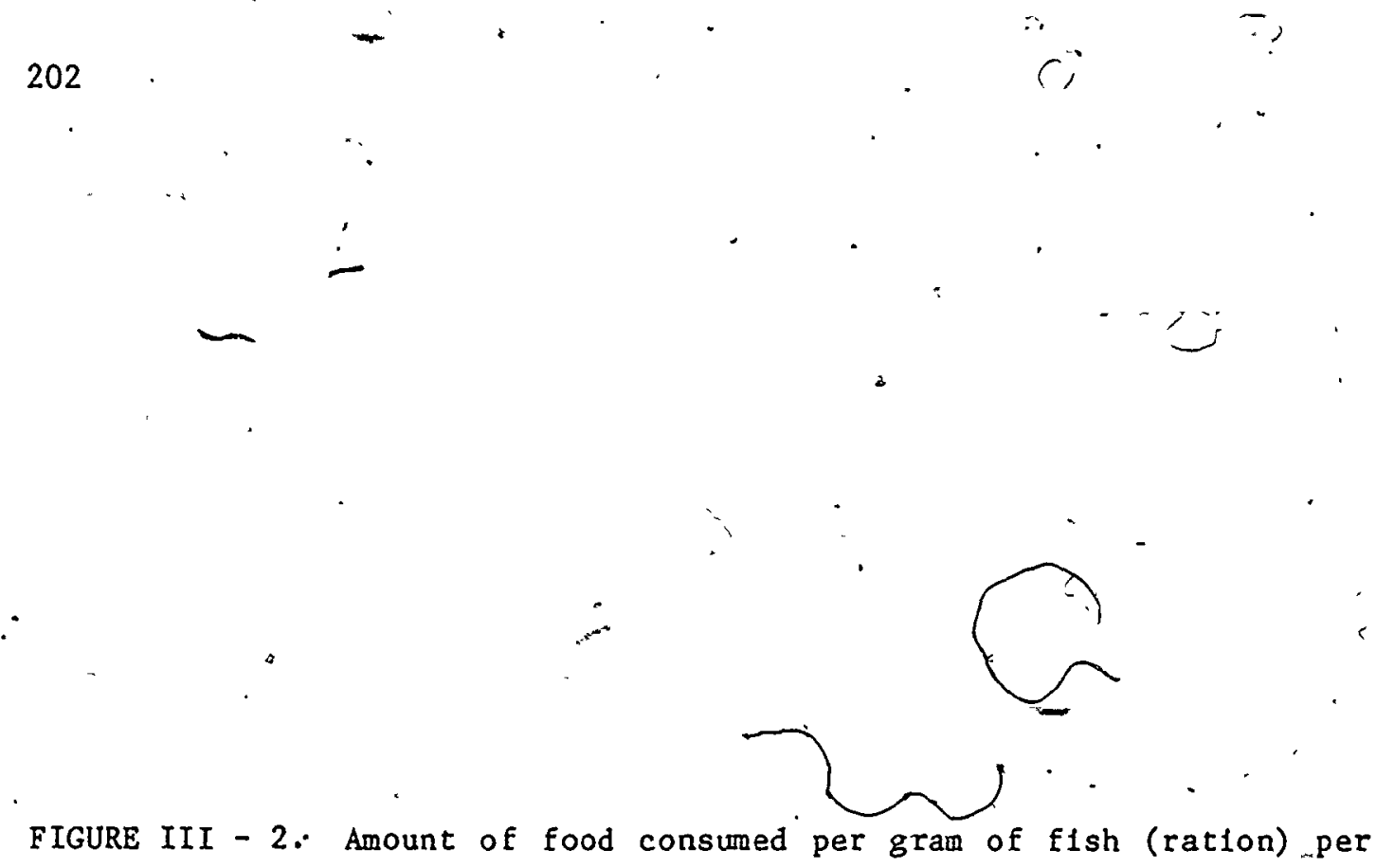
hour vs time of day. The horizontal axis. is shaded to show times of darkness. Bivalve rations are separated from amphipod and polyçhaetes because their evacuation rates differ. Negative values have no btological meaning. They are probably the result of the large number of empty stomachs collected during the evening

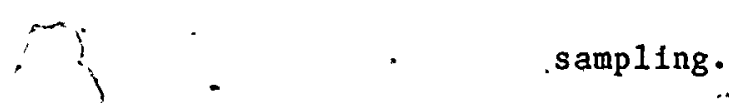


$c$

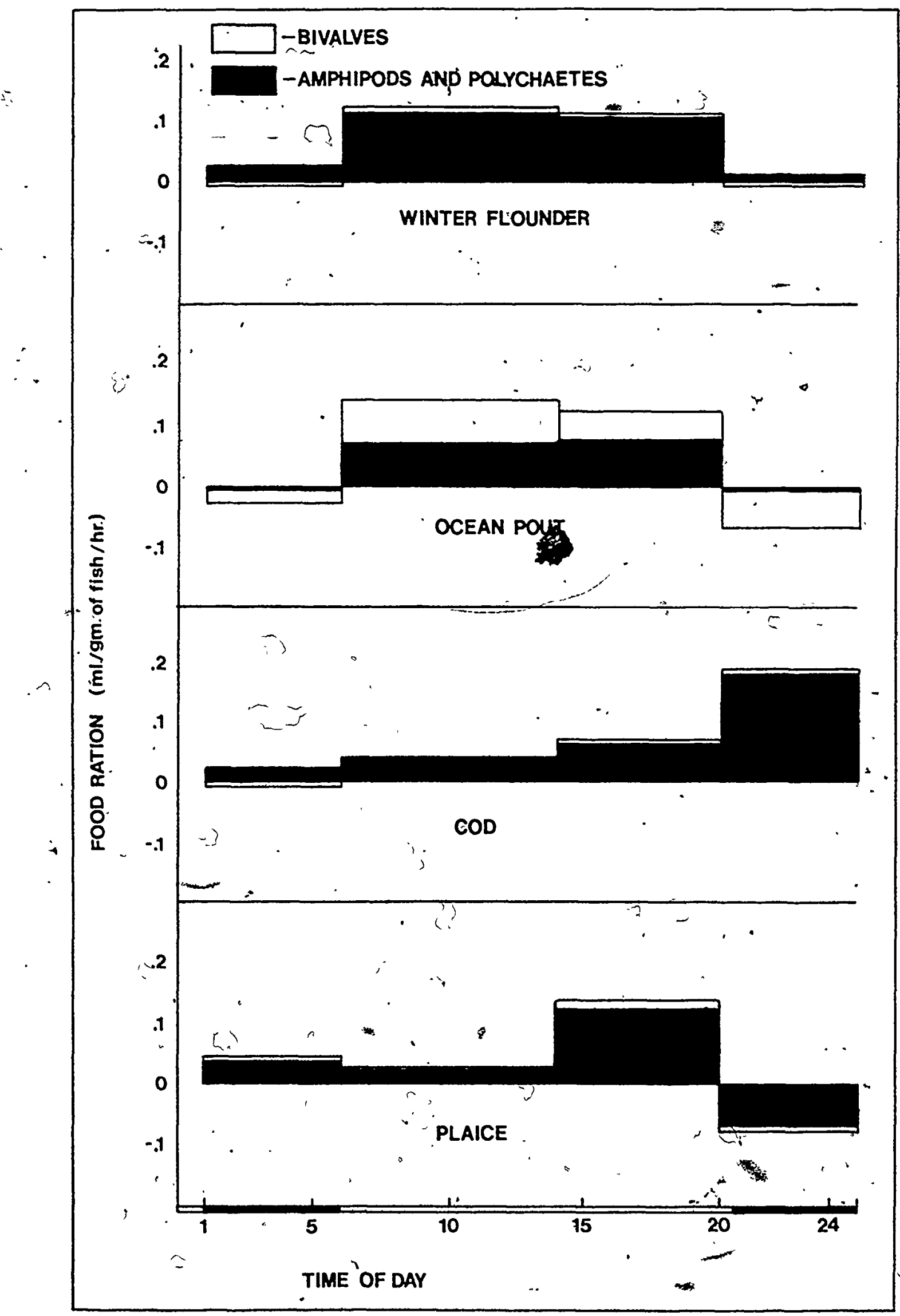


an increase in the volume of "food consumed with' increasing fish size (covariate $\mathrm{P}<0.10$ )

The greatest number of prey were consumed at midday by winter flounder, at midday, dawn and dusk by ocean pout, and later in the day by plaice (Fig. 3). Ocean pout and winter flounder consume a greater number of prey per fish than plaice or cod. Yoldia sapotilla was the primary food of ocean pout and plaice while amphipods were heavily utilized by winter flounder. Digestive indices could not be calculated for many of the prey consumed by cod (eg. Pandalus sp.). This may be the cause of the gaps and the apparent feeding perlodicity for cod on Fig. 3.

The type of food consumed by. each predator species did not change, among collection times (Fig. 2, 3). The slower evacuating prey species (Y. sapotíla) remain, identifiable longer snd, therefore, make up a larger proportion of the prey eaten the day before the collection (Fig. 3).

Daily ration estimates indicate that both winter flounder and ocean pout consume more food per fish than the other predators. However, when volume is. expressed as a percentage of body weight pẹr day (ie. corrected 全or interspecific size differences), winter flounder and cod have the highest́ ćonsumption rate followed by ocean pout and platce (Táble 1; Fig. 2). A large portion of the ocean pout dally ration is amphipods and polychaetes desplte the fact that bivalves are the major component of their stomach contents (Table 1 ). The negative ration values in the late evening for ocean pout and plafce have no blological meaning (Fig. 2). Food evacuation rate alone does not account for the large decrease in volume from the preceding collection. There were a large number of empty stomachs encountered in the late evening and therefore food volume 


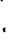

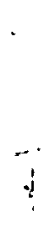

TABLE III - 1. Three

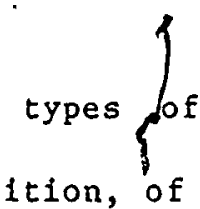

daily ration estimates, and percent composition, of each prey type consumed by each predator species. Daily ration as number of prey per day is calculated from Figure 3. Dịlly rations in volume per fish per day are calculated in two ways: (1) by multiplying number of each prey type per day times the average volume of one item and

(2.) from Elliott, and Persson's model-figure 2. Daily..ration is alsp presented as a percentage of body weight to allow compartisons with literature values.

$\infty$

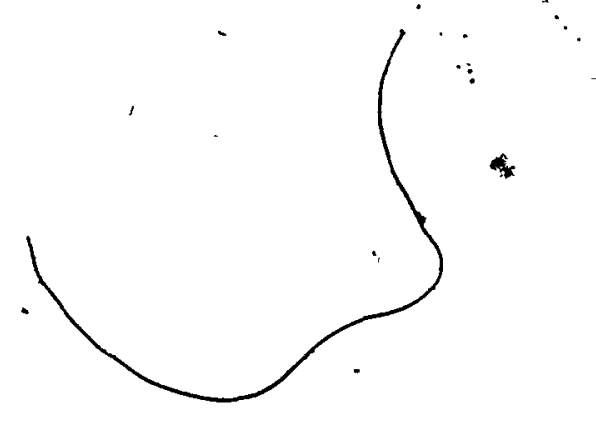




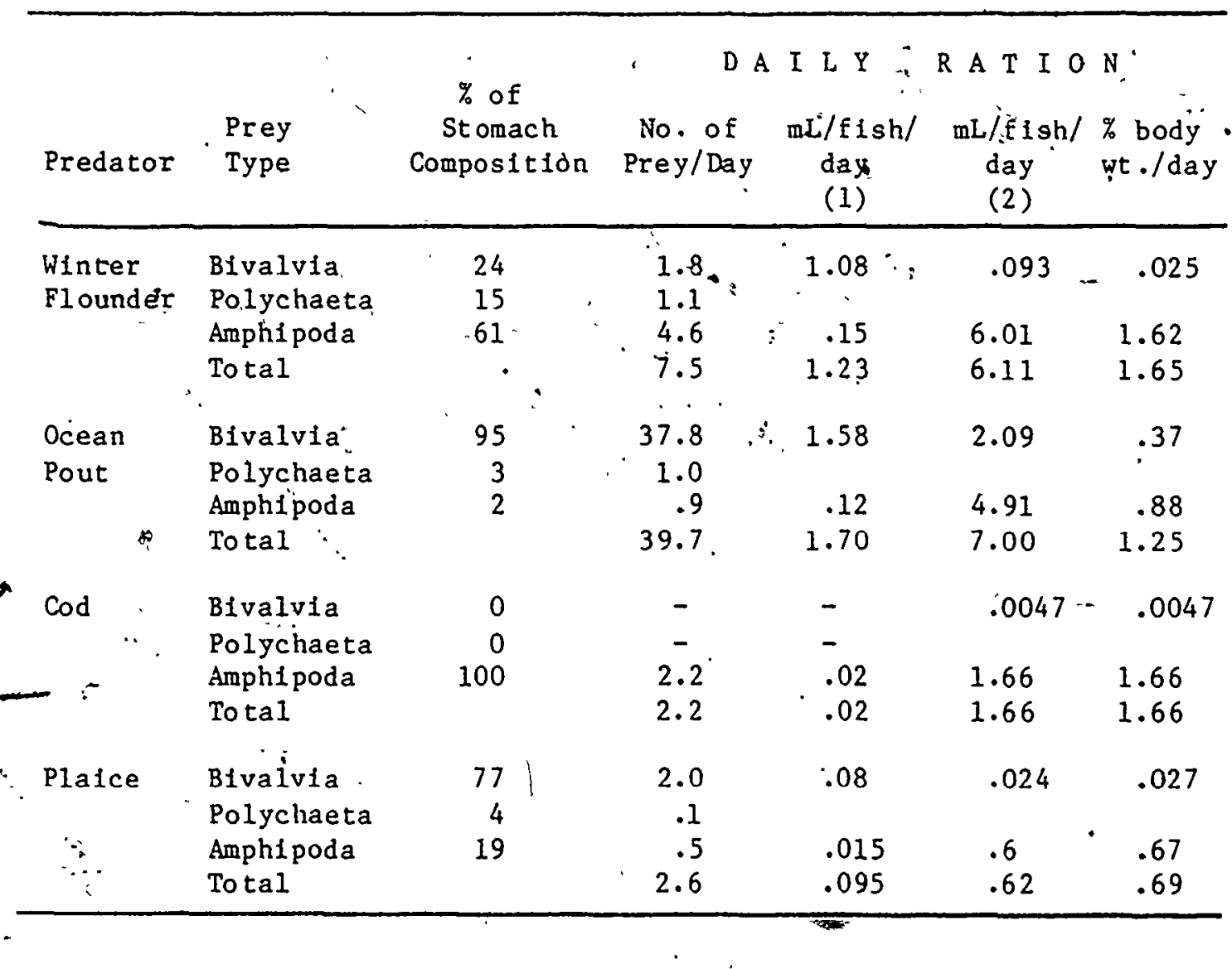

$c$

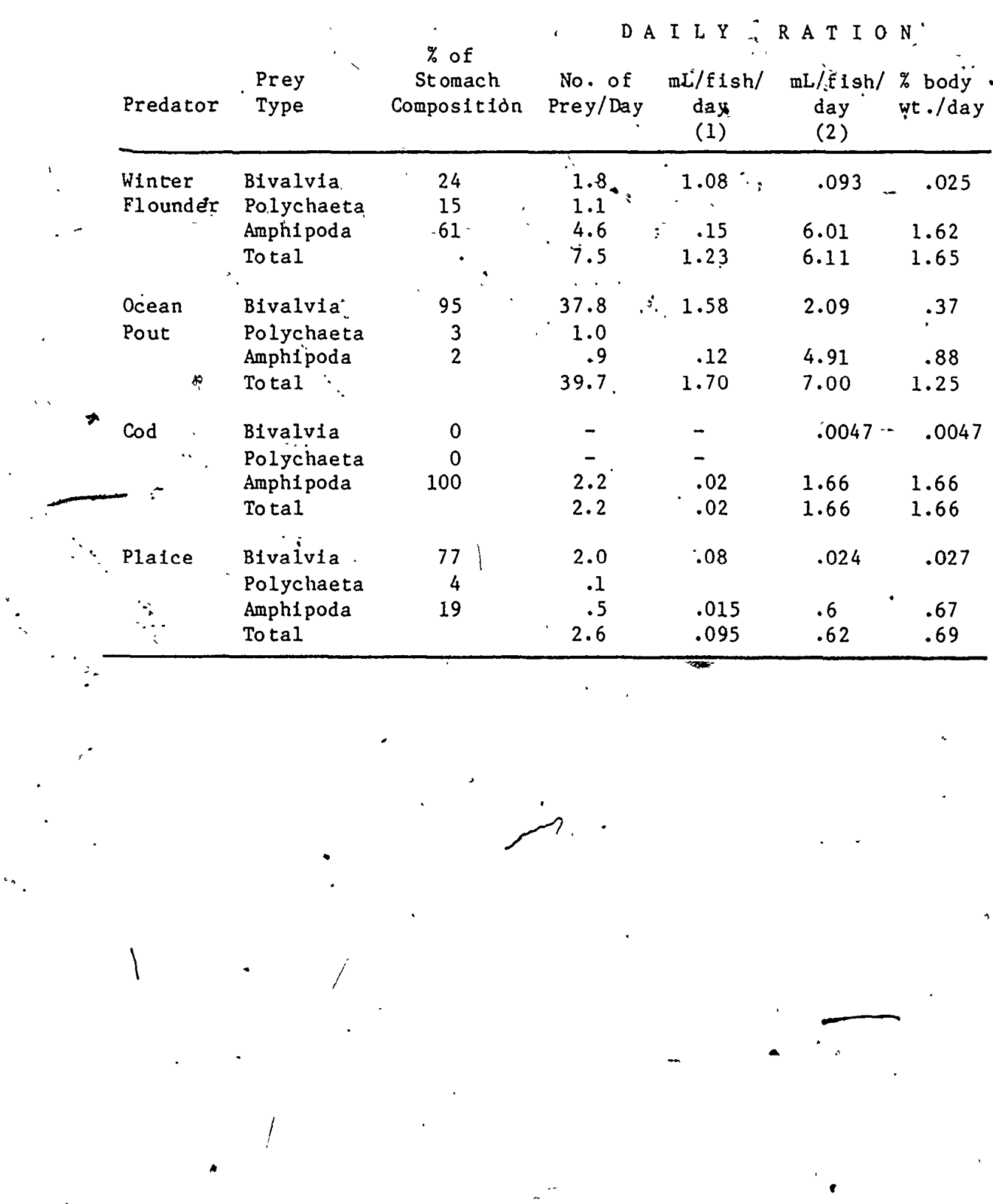




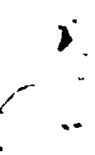

FIGURE III - 3. Plot of number of prey eaten per fish vs time of day consumed (times of darkness are shaded). ' Consumption. time was estimated using state-of-digestion indices. 


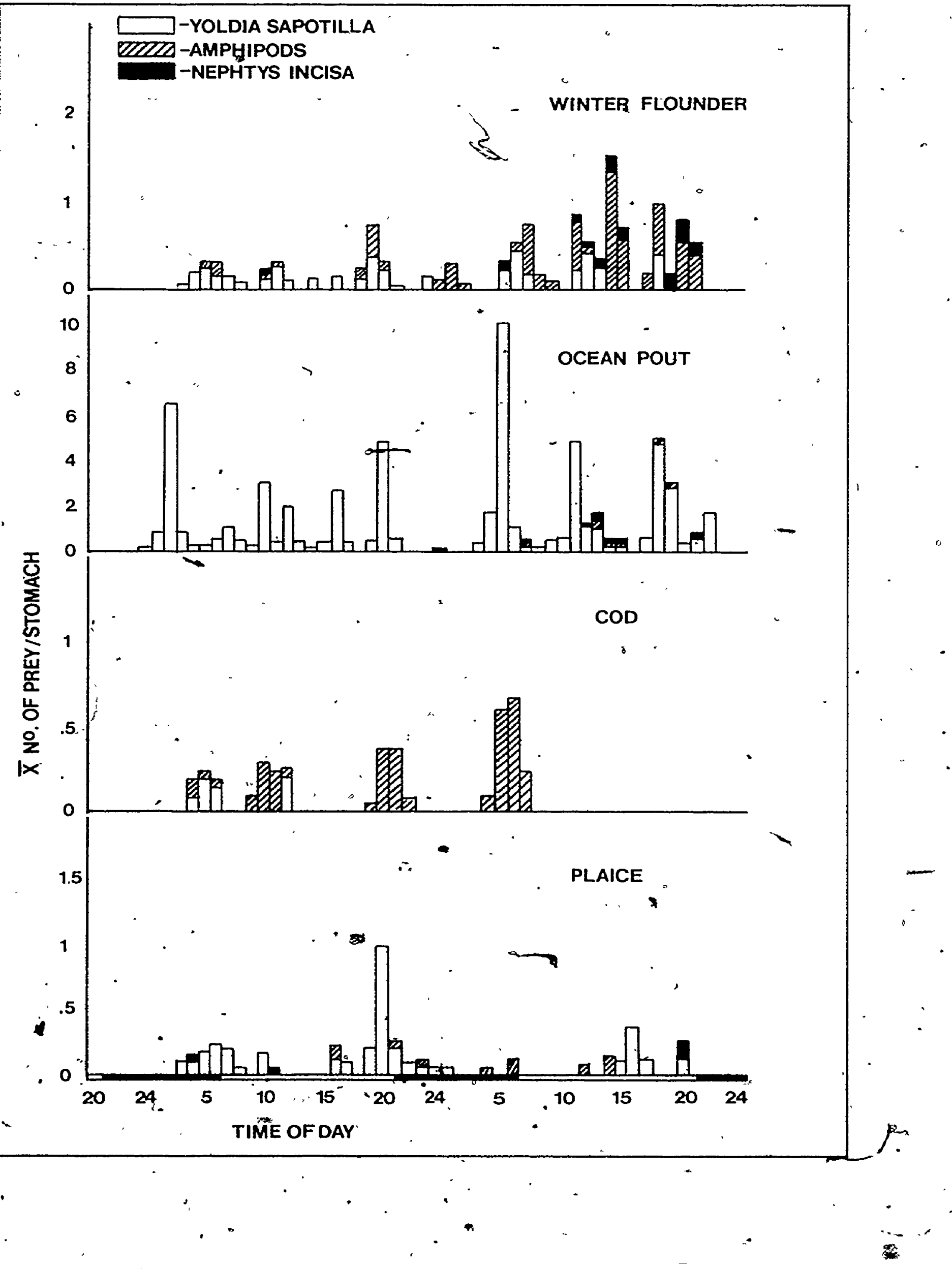


estimates are low. Possibly larger sample sizes are required to reduce the chance of getting large numbers of fish with empty stomachs. DISCUSSION

Feeding Periodicity

Two' basic problems often face researchers when analyzing feeding periodicity studies. Sample size often differs among collection times and larger fish eat more food than smaller fish causing fish size to be confounded with the effect time has on volume (Diana 1979; Edwards and. Bowman 1979). Unequal sample sizes can be dealt with by choosing among various weighted AÑoVAs or regressions in many statistical_. computer packages followed by plots of mean measures of amount consumed at each collection time (Windell 1978). Correction for fish size variation has been treated many ways." Some researchers choose to avold this problem by stratifying the fish into sufficiently lall length groups such that the length effect is insignificant (Doble and Eggers 1978; Windell 1978). This will work when sample sizes are large. All size categories can be pooled if analysis shows length effect to be insignificant. others ignore the problem altogether by plotting a food quantity measure from all sizes of fish vs collection time (Najim et al .1977). This method becomes less acceptable with increasing fish size vartation. Ca'tifish collected by Najim et al (1977) range from 105-185 mm. Volume of food required to fill the stomach probably changes within this, range. "The most common length correction method involves the calctulation of a ratio of stomach quantity (volume, number, or weight) to some measure 
o $\vec{f}$ fish size. Windell (1968) and Hureau (in Berg 1979) have developed. "fullness indit. that are food weight divided by fish weight. Keast and Webb (19.68), Fo 1 tz and Norden (1977), Clarke (1978), Nakashima and Leggett (1978), Cordes and Page (1979), Hacunda (1980), Godin (1981) and others have plotted $a$, fullness index, or some modification of it vs collection time to estimate peak feeding activity., Edwards and Bowman (1979) and Bowman and Bowman (1980) use the ratio of stomach quantity to intestinal quantity ( $\mathrm{S} / \mathrm{I}$ ratio) as a means of estimating feeding periodicity for some northwestern Atlantic fish, including the ocean pout. The S/I ratio is plotied for each sampled fish at different times of day. Unfortunately this ratio will be biased if, as in the ocean pout, the size proportion between stomach and intestine chànges as the fish grows (Edwards and Bowman 1979). Additionally, it does not consider the differences in food passage rates from stomach to intestine that have been shown to occur among fist species (Macdonald et al 1982). The ocean pout passes food to the intestine faster than other species. A large amount of food in the intestine in the afternoon may have been consumed during the morning, not during the night as Edwards and Bowman concluded. Ocean pout in Passamaquoddy. Bay are diurnal feeders with the greatest activity at dawn (Fig. 1).

Green (1979) has reviewed many of the problems assoclated with using two variables to create a ratio index. Ratios tend to increäse the variability of the original variables, blas the estimation of the true mean of the rątio, lead to nonnormal distributions and obscure intervariable relationships (Sokal and Rolhf 1973). While the results of many of the feeding ehronology studies that use ratio variables are valld, there are better ways of approaching this problem, particularly if 


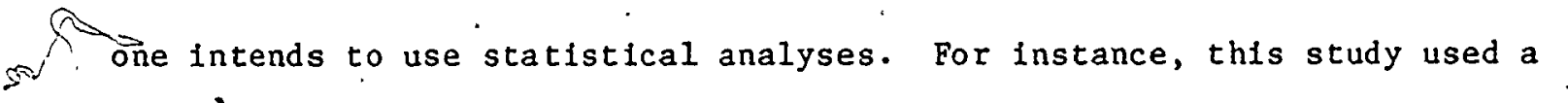

- two-way ANCOVA to test the maln effects. (time and fish species) with fish length ${ }^{a s}$ a covariate. Had the size range of fish in this study been larger, the covariate would have probably been signiflcant for more of the predator species. Interaction between the main effects indicates different times of peak feeding among the predator species (Fig. 1).

When evacuation rates are available the information from Figure 1 can be used to calculate amount of food consumed at different times of day (Fig. 2). This presents time of most intense feeding rather thàn time when food volume is greatest. Another advantage to this method is that it allows calculation of dally ration of each predator species. (Further discussion in the next section).

Many researchers have found a variety of flatfish species to depend on light for feeding (eg. Pearcy (1962), 011 a et al (1969), mand Hacunda (1980) using winter flounder and Olla et al (1972) using summer flounder (Paralichthys dentatus)). Others such as Tyler (1971) using winter lounder and Gibson (1980) using plaice (Pleuronectes platessa) describe patterns of movement and feeding that depend on the tidal rhythm. Theÿ. do not mention the effects of interaction between tidal rhythm and daylight on feeding behaviour. Brawn (1969) has described methods by which cod can capture food during day (sight) or night (taste). This supports the findings of this study and Hacunda's (1980) where no distinct diurnal pattern is seen. Different feeding times among fish species may serve to reduce interspecific competition. Future studies w111 be done at different times of year to see if feeding patterns change with different seasonal conditions. However, Doble and Éggers (1978) found no seasonal effect with sockeye salmon. 
The digested condition of prey has been used previously to estimate consumption time (Darnell and Meierotto 1962; 0lla et al 1969; Diana 1979). Feeding periodicity calculated using digestion indices considers relative evacuation rates of different food items. If indices are known - for a large percentage, of the prey species in the diet, this method will also provide $a$ rough estimate of dally ration in number of prey (Fig. 3 , Table 1). However, there are three disadvantages: 1) digestion indices are difficult to caIculate and herice have not been developed for many prey species; 2) their subjective nature prevents the use of confidence limits; 3) prothat have been consumed and evacuated within the sampling interval will, not be tallied. This problem is reduced by considering both stomach and intestinal contents. '(Further discussion in the next section).

Daily Ration

Published methods for quantifying dally ration depend on. measurements of metabolic requirements (Gerking 1972; Jones 1978), cyclic changes in the quantity of food in the stomach (Keast and Welsh 1968; Nakashima and Leggett 1978) or knowledge of the digestive rate equation of the fish and prey belng digested (Darnell and Melerotto 1962; Tyler and Dunn 1978; Doble and Eggers 1978; Elliott and Persson 1978; Huebner and Langton 1982). Metabolic methods and methods that depend on discontinuous feeding assume that all prey ispectes show similar evacuation characteristics. Incorporating evacuation rate differences among prey into dafly ration models provides a more exact estimate of daily consumption, and allows a quantitative description of predation 
pressure exerted by a predator on specific prey types (Huebner and Langton 1982, Fig..2). Figure 2 clearlys shows that, despite a heavy utilization of $\underline{Y}$. sapotilla by ocean pout ( $95 \%$ by number/fish) and a moderate utlization ( $24 \%$, by number/fish) by winter flounder (Table 1), the volume of bivalies consumed by both species is proportionally small. If the slow evacuating prey are not considered separately, they. will be over emphasized in the results. Calculating dally rations based on prey type permits the researcher to consider the amount of each prey type utilized after evacuation rates have been corrected for. It also allows for a more accurate food ration estimate as prey composition changes. Comparisons of daily ration estimates (mL/fish/day) between figure 2 (E1liott and Persson's model, 1978) and Figure $3^{\circ}$ (stage-of-digestion Indicos) show that over a $24 \mathrm{~h}$ period only the slow evacuating.pin species (bivalves) remain in the stomach long enough to assess accurately the ration froitidices of digestion (Table 1 ). Most predators digest amphipods and polychaetas so rapidly that their numbers and therefore volumes are drastically triderestimated. Indices of digestion should only be used to estimate ration over very short intervals (probably $5 \mathrm{~h}$ ). Indices of digestion are of more value to estimate time than rate of feeding (see previous section of the discussion).

The winter flounder dafly ration estimate ( $1.65 \%$ body wt/day) was lower but similar to the estimates of Tyler and Dunn ( $2 \%$ for dally fed fish) and Huebner and Langton (1.8-2.4\%) for laboratory studies at a simflar temperature (Table 1). The Elliott and Persson (1978) model used - has a tendency to underestimate amount of food consumed as length of time between sampling perfods increases. Sample intervals will be minfinized $\checkmark$ in the future. 
Winter flounder and cod had higher dally rations (per gram of fish) of food that has higher caloric value than food of the other fish (Tyler 1973). This suggests that they have higher rates of growth or higher metabolic activities. Laboratory observations suggest that winter flopnder and cod are more active than ocean pout. Plafce feed throughout the year and therefore require less per season. Future work should consfder the effects season and bottom temperature have on daily ration so that a yearly ration can be calculated:

It is Impossible to apply confidence limits or statistical tests to ration estimates collected from field data. Knowledge of stomach content quantity at the beginning and end $=0$ each collection interval for each fish is required to obtain an estimate of variance about the mean ration. . Such information can be collected only by following the progress of individual fish in the-laboratory.

Oür perception of feeding periodicity and daily ration of fishes in the natural environment is affected by the variation in digestion rates among predator and prey spectes. Knowledge of the nature of this ' variation and the correct analysis techniques are required in the design of future studies on the interaction among fishes and their environment. 
ACKNOWLEDGEMENTS

We are grateful to many of the staff at the St. Andrews Biological Station and the Huntsman Marine Laboratory, Including Dr. M.J. Dadswell, Mr. D. Bettie and Ms. C. Carver for their assistance during this study. Thanks also to Dr. R.H. Green and Dr. G. Wells for their critical review. of this paper. The work done by J.S. Macdonald was in partial fulfillment of PhD. studies supported by NSERC operating and strategic grants to Dr. R.H. Green. - 


\section{REFERENCES}

BERG, J. 1979. Discussion of methods of investigating the food. of fishes, with, reference to. a preliminary study of the prey of - Goblusculus flavescens (Gobildae). Marine Blology 50: 263-273. BOWMAN, R.E., and E.W. BOWMAN. 1980. Diurnal varlation in feeding intensity and catchability of Silver Lake (Meriucicius bilinearis): Can. J. Fish. Aquat. Sc1.' 37: 15 $65-1572$.

BRAWN, V.M. 1969. Feeding behaviour of cod (Gadus morhua). J. Fish. Res. Board Can. 26: 583-596.

CLARKE, T.A. 1978. Diel ${ }^{\infty}$ feeding patterns of 16 species of mesopelagic flshes from Hawalian waters. Fish. Bull. 76: 495-514.

COCHRAN, P.A. 1979. Some recent methods for estimating food consumption by fish. I. Fish. Res. Board Can. 36: 1018.

CORDES, L.E., and L.M. PAGE. 1980. Feeding chronology and diet composition of two darters (Percidae) in the. Iroquois River system, Illinois: Amer. Midland Nat. 104: 202-206.

DARNELL, R.M., and R.R. MEIEROTTO. 19.62." Determination of feeding . chronology in fishes. Trans. Am. Fish. Soc. 91: 313-320. DIANA, J.S.3 1979. The feeding pattern and dally ration of a top carnivore, the northern pike. Can. J. Zool. 57: 2121-2127.. DOBLE, B.D:, and D.M. EGGERS. 1978. Diel feeding chronology, rate of gastric evacuation, dafly ration and prey. selectivity in Lake Washington juvenile sockeye salmon (Oncorhynchus nerka). Trans. Am. F1sh. Soc. 107: $-36-4.5$.

EDWARD, R.L., and R.E. BOWMAN: 1979. 'Food consumed by continental shelf f.1shes p.387-406. In R.H. Stroud and H. Clepper [ed.] Predatór- 
prey systems in fisheries management. Sport Fishịng Inst., Wash. D.C.

EGGERS, D.M. 1977. Factors in-interpreting datä obtained by diel sampling of fish stomachs. 'J. Fish. Res. Board Can. 34: 290-294. ELLIOTT, J.M., and L. PERSSON. 1978. The estimation of dally rates of food consumption for fish. J.' Anim. Ecol. 47: 977-991.

FOLTZ, J.H., and C.R. NORDEN. 1977. Food habits and feeding chronolog 9 of rainbow smelt, Osmerus mordax, in Lake Michigan. Fish. Bull, 75: $637-640$

GERKING, S.D. 1972. Revised food consunption estimate of a blue g111 sunfish population in Wyland Lake, Indiana, U.S.A. J. Fish. Biol. 4: $301-308$

GIBSON, R.N. 1980. 'A quantitative description of the behaviour of wild juvenile plaice (heuronectes platessa $\hat{L}:$ ). Anim. Behav. 28: 12021216

GODIN, J.-G:J. 1981. DaIly patterns of feeding behaviour, dally raxions and diets of juvenile pink sạlmon (Oncorhynchus gorbuscha) in two mârine bays of B.C. Can. J. Fish. Aquat. Sc1. 38: 10-15.

GREEN, R.H. 1979. 'Sampling design and statistical methods for environmental biologists. John Wiley, and Sons, Toronto. 257 . HÁCUNDA, J.S. 1980. Food resource partioning by a demersal flsh community in a coastal area of the Gulf of Maine. MSc Thests Univ. of Maine, U.S.A. 49 .

HUEBNER, J.D., and R.W. LANGTON: 1982. Rate of gastric evacuation for winter flounder (Ṕseudopleuronectes americanus). Can. J. Fish. Aquat. Sci. 39: 356-360. 
- JOBLiNG, M. 1981. Mathematical models of gastric emptying and the estimation of daily rates of food consumption for fish. J. Fish. ₹ Biol. 19: 245-258. -

JONES, $<$ R. 1978. Estimates of the food consumption of haddock (Melanogrammonus aeglefinus) and $\operatorname{cod}$ (Gadus morhua). J. Cons. int. Explor. Mer. 38: 18-27.

KEAST, A.ं, and L. WELSH. 1968. Daily feeding periodicities, food uptake rates and dietary changes with hour of day in some lake fishes. J. Fish. Res. Board Cạn. 25: 1133-1144.

MACDONALD, J.S., K.G. WAIWOOD, and R.H. GREEN. 1982. Rates of digestion off different prey in Atlantic cod (Gadus morhua), ocean pout. (Macrozoarces americanus), winter flounder (Pseudopleurenectes americánus) and American plaice (Hippoglossoldes platessoides). Can. J. Fish. Aquíat. Sci. 39: 651-659.

NAKA'SHIMA, B.S., and W.C. LEGGETT. 1978. Daily ration of yellow perch

(Perca flavescens) from Lake Memphremagog, Quebec - Vermont, with a comparison of methods for in situ determinations. J. Fish. Res. Board Can. 35: 1597-1603.

OLLA, B., C.E. SAMET, and A.L. STUDHOLME. 1972. Açtivity and feeding behaviour of the summer flounder under controlled "laboratory conditións. Fish. Bull. 70: 1127-1136.

OLLA, B.L., R. WICKLUND, and S. WILK. 1969. Behaviour of winter flounder In a natural habitat. Trans._Am. Fish. Soc. 4: 717-720. PEARCY, W.G. 1962. Ecology of an estuarine population of winter flounder, Pseudopleuronectes americanus (Walbaum) IV food hablts and larvae and juveniles. Bull. Bingham Oceangr. Coll. 18: 1-78. SOKAL, R.R., and F.J. ROHLF. 1973. Introduction to Biostatistics. W.H. 
Freeman and Co., San Francisco. 368p.

TYLER, A.V. 1971. Surges of winter flounder in the intertidal zone. J. Fish. Res. Board Can. 28: 1727-1732.

TYLER, A.V. 1973. Caloric values of some North At lantic invertebrates. Marine Biol. 19: 258-261.

TYLER, A.V., and R.S. DUNN. 1976. Ration growth and measures of somatic organ condition in relation to meal frequency in winter flounder (Pseudopleuronectes americanus) with hypotheses regarding population homeostasis. J. Fish. Res. Board Can. 33:, 63-75. WINDELL, J.T. 1978. Estimating food consumption rates of fish populations p.227-254. In T. Bagnel [ed.] Methods for assessment of fish production in fresh waters ( 6 th ed.). Blackwell Scientific" Publications, Oxford. 
3

APPENDIX IV

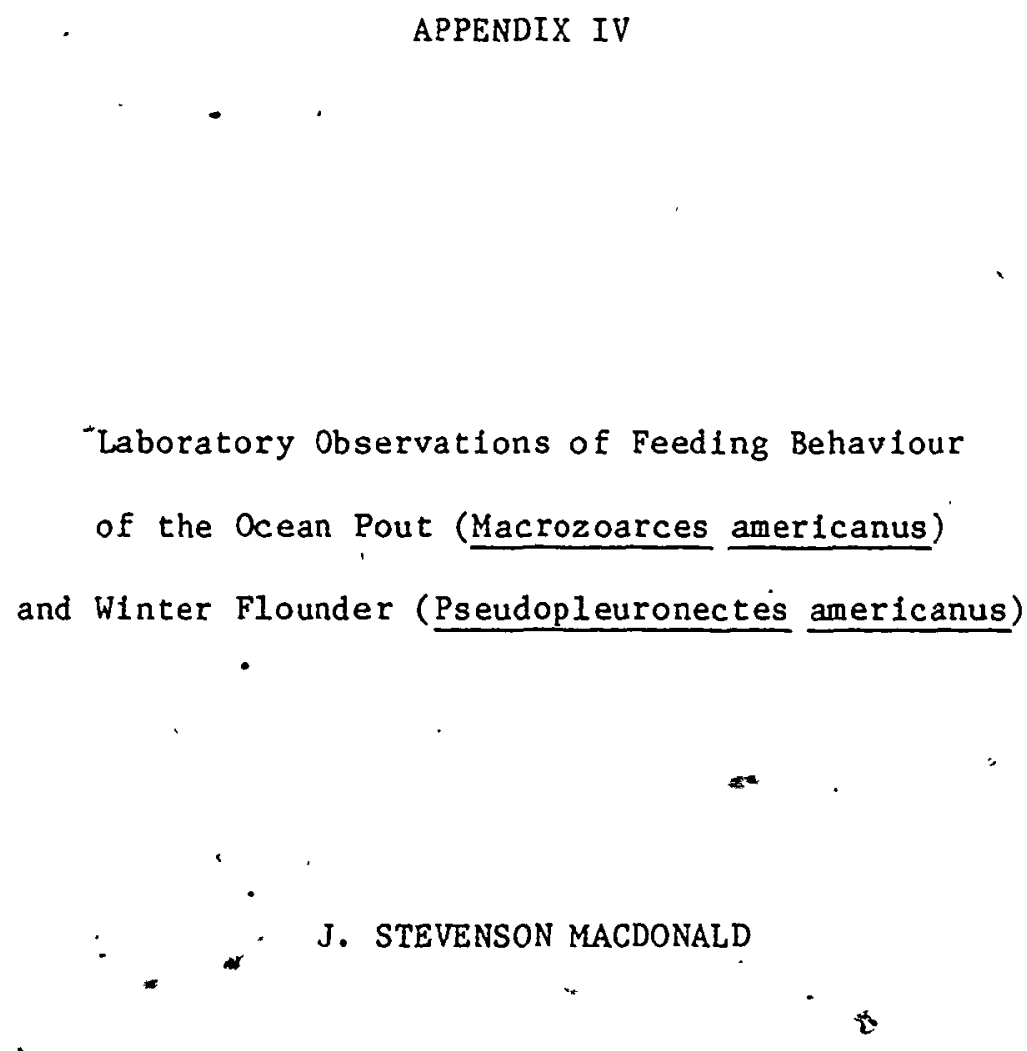

Department of Zoology, University of Western 'Ontario, London, Ont. N6A 5B7,

at 
Attempts have recently been made to isolate, some of the factors involved in the choice of food by fish; Including descriptions of prey organisms available to the fish while they are feeding (Frame, 1976; Hacunda, 1980; Hyatt; 1979): Howẹer, prey availability is only one of the many factors involved in prey cholce. Moore and Moore (1976) also cite search image development, escape res se and degree of concealment of prey and, most significantly for the purposes of this paper; hunting efficiency of the fish. Tyler (1972), and Hyatt (1979) suggest that differences between predators in hunting efficlency fot different prey may be responsible for resource division.

The feeding behaviour of many benthic fish is well documented. The foraging, behaviour of cod.has been studied by Brawn.(1969), the gurnard, the, dragonet and some flounders by Stevens (1930) and many other flatfish by 011 a et al $(1969,1972)$, de Groot $(1969,1971)$ and Stickney et al (1973). However, with the exception of Brawn's . work and field observations by 01la on the winter flounder. there is. little, published Information about methods of foraging on natural prey by common fishes of the northwestern. At lantic.

Many diet studies have provided insight into food sellection by benthic feeding, fish in the northwestern Atlantic. Tyler $(1971 \mathrm{~b}, 1972)$ and the author (unpublished observations) hạe found that ocean pout (Macrozoarces americanus, Zoarcidae) eat 'large numbers of sedentary polychaetes (eg. Sternaspis scutata) and molluscs (eg., Yoldia sapotilla) from the environment. The winter Flounder (Pseudopleuronectes americanus, Pleuronectidaę) consumes fewer bivalves in favour of 
polychaetes. (eg:, Nephtys incisa) and amphipods (eg., Cásco bigelowi). In. this paper the behaviour of the ocean pout and the winter flounder in searching, detection, capture and ingestion of prey was studied under a variety of läböratory conditions. The influence of feeding methods on $\because$ the type of prey taken was considerèd.

\section{MATERIALS . AND METHODS}

Feeding observations were made on nine winter flounders $(18-35 \mathrm{~cm}$ 'total: length, T.L.) and eight. ocean pout \$4 $4-60 \mathrm{~cm}$ 'T.L.) that were collected in a shrimp trawl in the spring of 1980 in Passamaquodidy Bay, N.B., Canada. They were fed five prey species that.were collectied in a fine mesh-IIned scallop dredge: the amphipod Casco bigelowi $(.85-1.10$ cm T.L.), the blvalve Yoldia sapotilla $(.4-. .5$ cm T.L.), the scaphopod Dentalium entale. $\left(1.5-3.0{ }^{\circ} \mathrm{cm}\right.$ T.L.) and the polychaetes Sternaspis Scutata $\left(.52-1.0 \mathrm{~T} . \mathrm{L}_{.}\right)$and Nephtys incisa $(4.3-6.5 \mathrm{~cm}$ T.L.; Table 1$)$.

Fishes were kept together in a $2 \times 5 \times 2 \mathrm{~m}$ deep $20,000 \mathrm{~L}$ tank at the Huntsman Marine Laboratory Public. Aquarium. Seven $\ddot{c}$ of fine sand covered the bottom of the tank. Several rocks, she11s, logs ard piants (Ascophylum sp.) provided shelter for the fishes and the prey species: Durtig a one month acclimation period fish were held at ambient temperatures $\left(12^{\circ} \mathrm{C}\right)$ and salinities $\left(28-31^{\circ} \% 00\right)$ and under a natural .photopertod (12L/12D). They fed on several spectes of mollusks and crustdceans that were present in the tank before the experiment started, and on a supplemented diet of sliced herring. No herring was fed to the fishes for a period of $72 \mathrm{~h}$ before the experiment commenced. Three plastic pipes $(15 \mathrm{~cm} \times 1.5 \mathrm{~m})$ were placed on end in the bottom

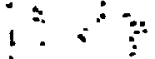




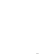

spediment of the study tank. They were attached to supports above tank. One end of each pipe cleared the surface of the water, allowing different prey species to be introduced onto. the substrate through each pipe: "Several individuals of each prey species were placed in each pipe before each observation period. The prey were allowed to acclimate in the sand for $1 \mathrm{~h}$ before the pipes were removed. This presentation method permitted the prey items to. assume natural positions in the habitat before being exposed to the predators.

Observations were made for a period of $1 \mathrm{~h}$ after removal of the pipes. This was repeated during the morning and afternoon for 6 consecutive days (12 $h$, observation time). Times between first feeding response and. successful consumption of the prey were recorded with a stopwatch. The - positions of the pipes within the tank and therefore the positions where prey were presented were randomized to prevent the fish from developing a searching pattern. During the course of.the experiment the fishes did not orient to the prey introduction pipes. When searching for prey the fishes divided, their time among the many types of substrates available. Both spectes of fish were also fed boluses of prepared food ( $7 \mathrm{~mm}$ to $14 \mathrm{~mm}$ in diameter) to assess the fimportance that morement of the food had on feeding response, and handling methods. The prepared food conststed of , $32 \%$ ground-up winter flounder, squid and scrab, $53 \%$ herring meal, $12 \%, *$ herring oil, $3 \%$ vitamins and a binding agent., On seven occasians with each predator species, boluses were attached to the end of a long piece of fine wire and pulled slowly along the bottom of the tank. The responses of each fish were observed. The responses of all fishes as they fed on herring and prepared food dropped from the water surface was also' observed. .' 
To assess the sensory functions of the large lips of ocean pout, 60 - histological cross sections, 7 microns thick, were taken from the ventral surface of the upper lips and dorsal surface of the lower 1ips of one fish. The sections were stained with Ehrlich's alum haematoxylin and Bowie's eosin, dehydrated in a technicon automatic tissue processor and embedded in tissue prep.

\section{RESULTS}

(a) Winter flounder: The winter flounder crawledsand shambled (Kruuk, if 63) across the bottom with their heads ralsed during times of feeding on Ne and prepared food. Shambling has been described by Kruuk (1963) as a combination of swimming close to the sand and crawling at speeds of approximafely $40 \mathrm{~cm} / \mathrm{sec}$. The eyes projected from the head and moved independgntiy to give the fish a field of vision wider than $180^{\circ}$. Once a potertal prey object was sighted, the fish shambled toward it until the prey was 2-3 cm frołn the mouth. The head was then pointed toward the prey. at an angle of approximately $30^{\circ}$ below the horizontal. The body was arched downward with the dorsal and anal fins braced in the sand. A short lunge or peck secured the food item (Fig. I). During this sequence the eyes appeared to be continuously focused on the prey. Suction created from the expansion of the opercula was used in conjunction with the lunge to capture all prey. This method was particularly important when capturing mobile amphipods and errantid polychaetes. In all cases the flounder took single ftems with each peck and were never observed taklng mouthfuls of sand to sort in their mouths.

In most cases the flounder were more likely to respond to moving than. 

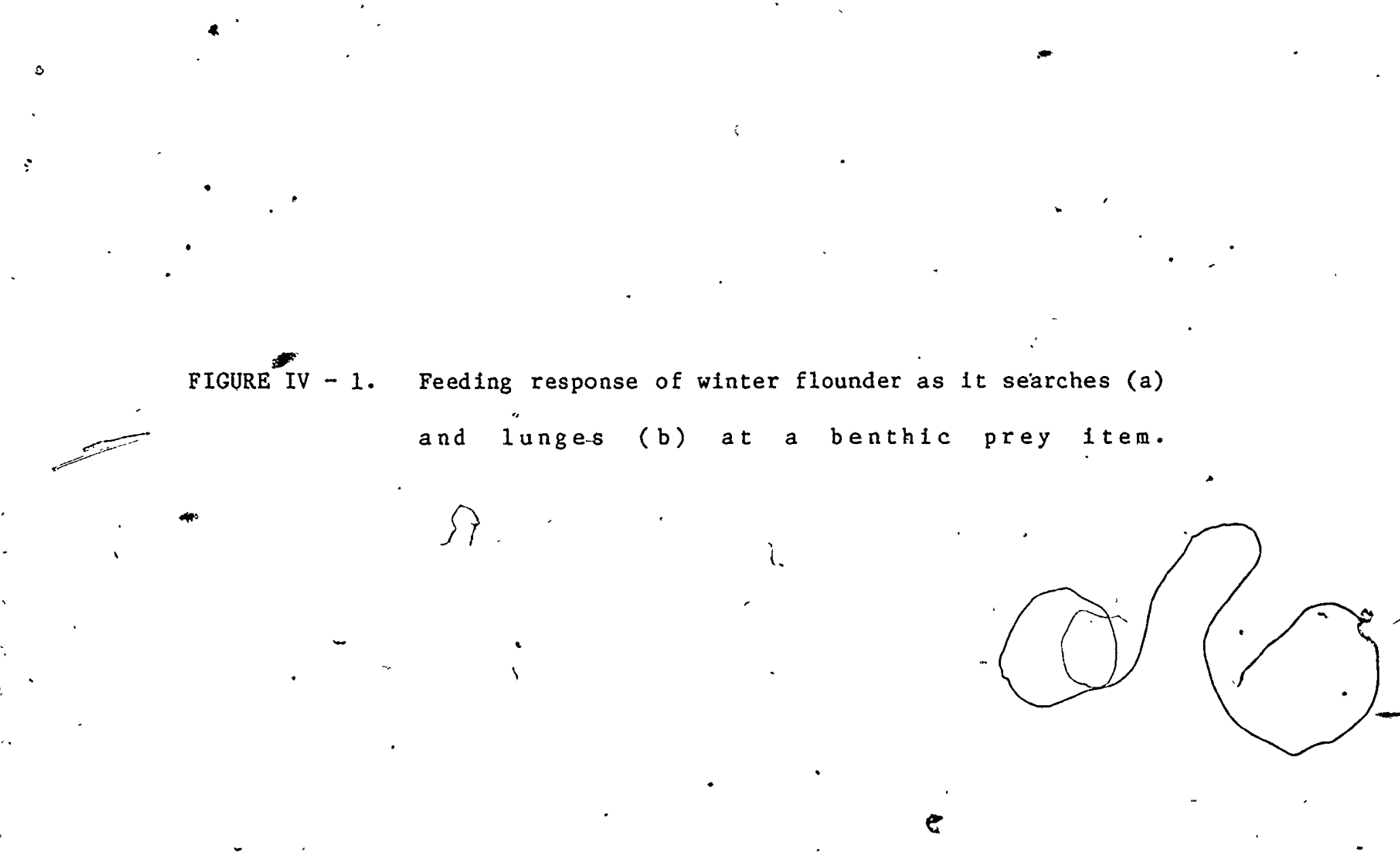

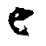

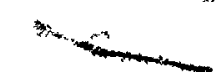

\& 


\section{0}

.

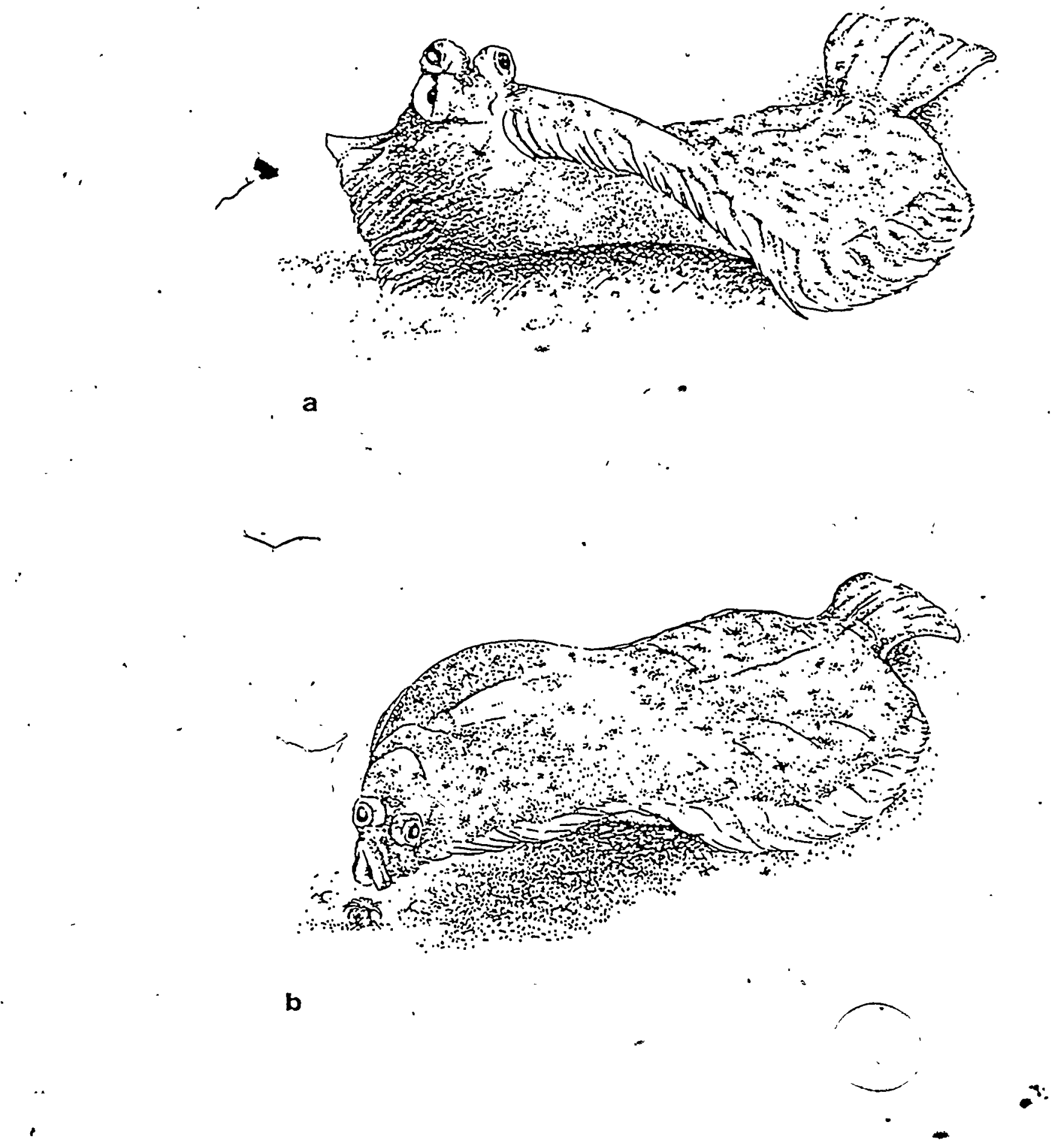


$\begin{array}{lll} & & \\ \text { stationary prey. This applied to swiming amphipods, crawling }\end{array}$ polychaetes and foot or siphon movements of molluscs. On two occasions, two flounders were observed to peck at the tips of moving fin rays of other buried flounders. Flounders that did not feed voluntarily on natural of stationary prepared food could be stimulated to feed on a bolus of prepared food bounced gently along the bottom on the end of a fine wire.

Food was usually taken in one or two pecks. This was" followed by a few seconds of pharyngeo-esophageal activity, presumably to break up and swallow the prey (described as chewing by Gibson, 1980). Judging from stomach contents, the pharyngeal teeth flattened or partially crushed the exoskeletons of amphipods and shells of mollusks (unpublished observations). However, larger items that did not $f(t)$ into a flounder's mouth (eg. large mollusks) were bitten many times, held in the jaws by the viscera and then shaken up and down rapidiy. It is assumed that this sood was too large to fit through the flounders' relatively small mouths. This served to break a portion of flesh off or to crack the she11. Four Individual flounders were observed to do this to eight $\underline{Y}$. sapotilla and two D. entale. One 18-cm flounder spent $11 \mathrm{~m} 1 \mathrm{n}$ pulverizing one mollusk although the average handling time for all bivalves was approximately one min. The average handling time for all other natural prey, did not exceed eight sec. (Table 1). Unfortunately no quantitative Information on the effect of fish size on handling time was collected. Only small flounder shook mollusks in this manner.

Simllarly, the flounder responded to larger bolusestof prepared food even though they required shaking and biting before they would fit into their mouths. It took $10-25 \mathrm{sec}$ for a bolus to be chewed by the 
228

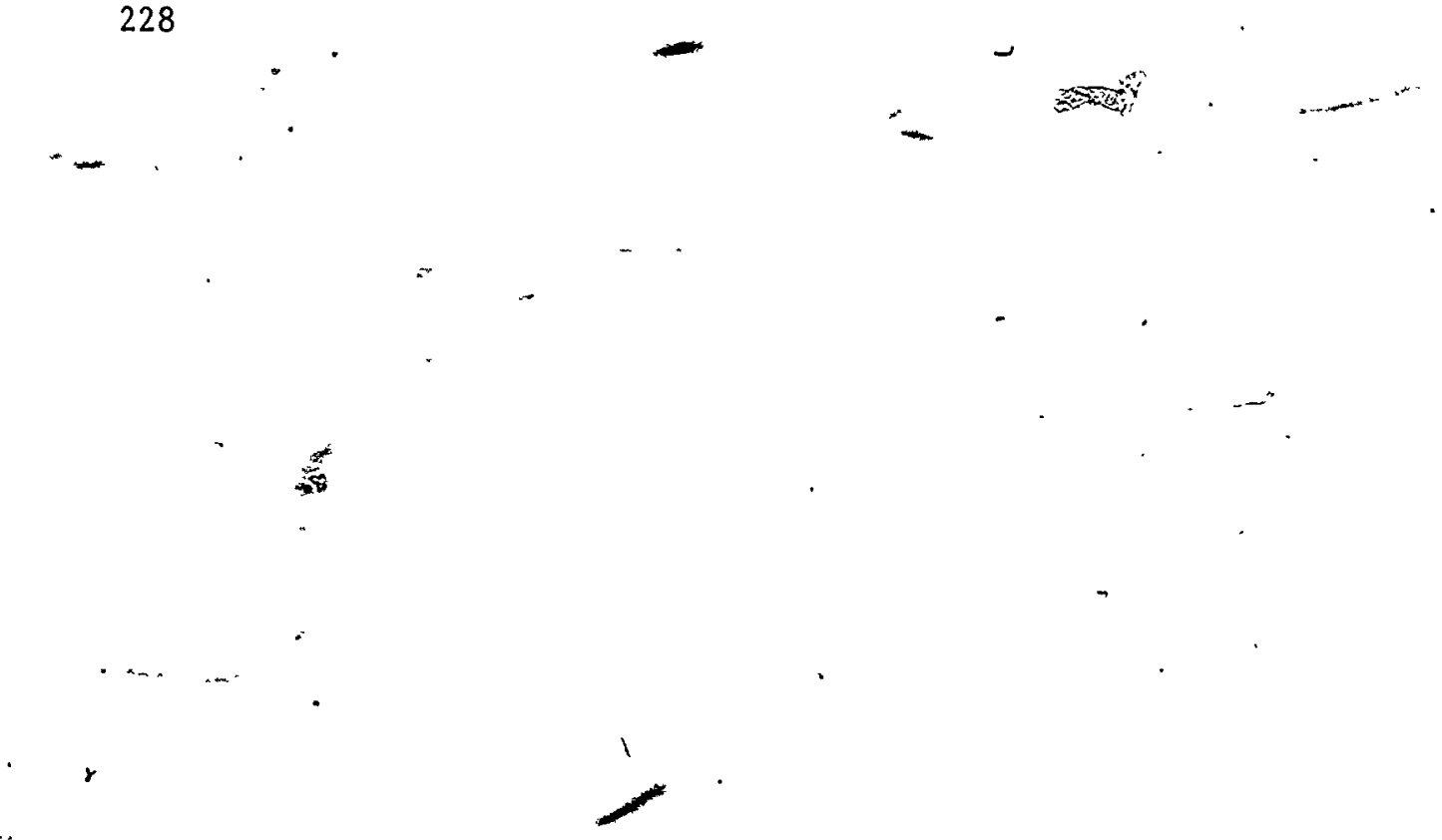

t

TABLE IV - 1. Handing time (in seconds) for each of the prey by both predators. Values record time between first feeding reśponse (1e. peck or lungê) and successful consumption of prey. Handling time of prey acquired by sorting mouthfuls 1. 2 of sediment was not recorded. 


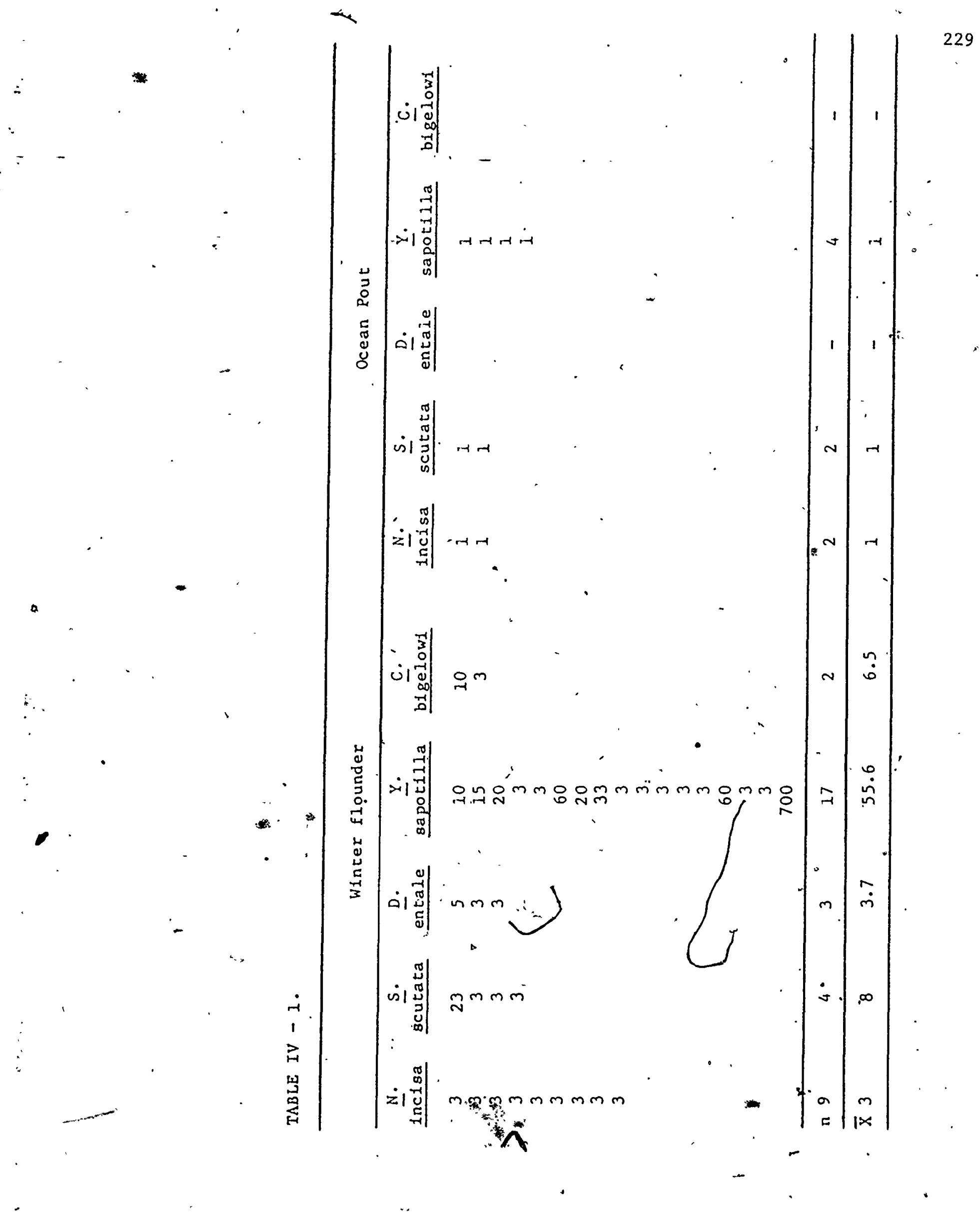


pharyngeal teeth before swallowing. During chewing, portions of the food were expelled through the 'gill aperture.

(b) Qcean pout: When forraging, the ocean pout swan a few centimeters from the bottom, then settled on the sediment. While on the sediment, " the tail was colled and the head and eyes pivoted to scan the environment. The colled tall acted as a base from which the head was extended to capture prey. Food was consumed by a rapld scooping motion of the lower jaw in conjunction with ppercular suction. However, potential prey (eg. amphipods or polychaetes) were often not seen by a feeding fish even when they were swimming or crawling a few centimeters from the fish's head. A large or small bolus of prepared food was as likely to be responded to when stationary as it was while in motion. When moving food was lunged at, it was often $\dot{m}$ issed. Handling thes were difficult to collect because it was often difficult to see which prey the ocean pout were feeding on. Mean time taken to handle all prey species was one sec.

I A disturbance of the sediment, such as a flounder burying itself, quickly attracted one or more ocean pout from at least a meter away. Th1s was observed eight times. In three different fish. No potential food was ever exposed by these disturbances, so the fish were not observed feeding.

Three ocean pouts were seen filling their mouths with sediment. To collect the sediment, the head was tllted downwards and the lower jaw scooped a trench 2-3. cm long and 3-5 mm deep. The hèd was held at an angle that allowed both the lower and upper lips to come In contact with the substrate. The sediment was mixed in the mouth for 10-30 sec and 
then spit out, a bit at a time (Fig. 2). This behaviour was observed 17 - times, often at the same location. It did not always result in the discovery of food because ocean pout sampled throughout the tank, not " only in areas where food had been placed. It was difficult to sée how many items were eaten and when they were swallowed.

An alternative type of digging behaviour was observed on two occasions when an ocean pout used its upper lip to ovierturn a large shell.

The ocean pout rarely left the botton to feed. They maneuvered very poorly when off the bottom, often snapping at but missing prepared food that was dropped from (the water's surface.

Observations of the histological sections revealed both taste bud. ' organs and pressure senstitive tactile papillạe or ridges on the ventral surface of the upper 11 p (pers. comm. Mr. R. Harris, U.W.O.). The lower. lip had taste bud organs and mucus glands in the epidermal layer. Sections also revealed unattached longitudinal bone ór cartilage that may act to stiffèn the lower 11p. Both longitudinal and cross sectional voluntary muscles were attached to the bone and could be used to roll the I1p backwards and forwards or draw it into a scoop shape.

\section{DISCUSSION}

Some of the observations made during this experiment have been described for other species of flounders. The shambling movements while seeking food were originally described by Kruuk (1963) for Solea vulgaris, and have since been used to describe the movements of Pleuronectes platessa by Gibson (1980). They have also been described as cephalocaudal movements for Paralichthys dentatus by 011 a te al (1972). 

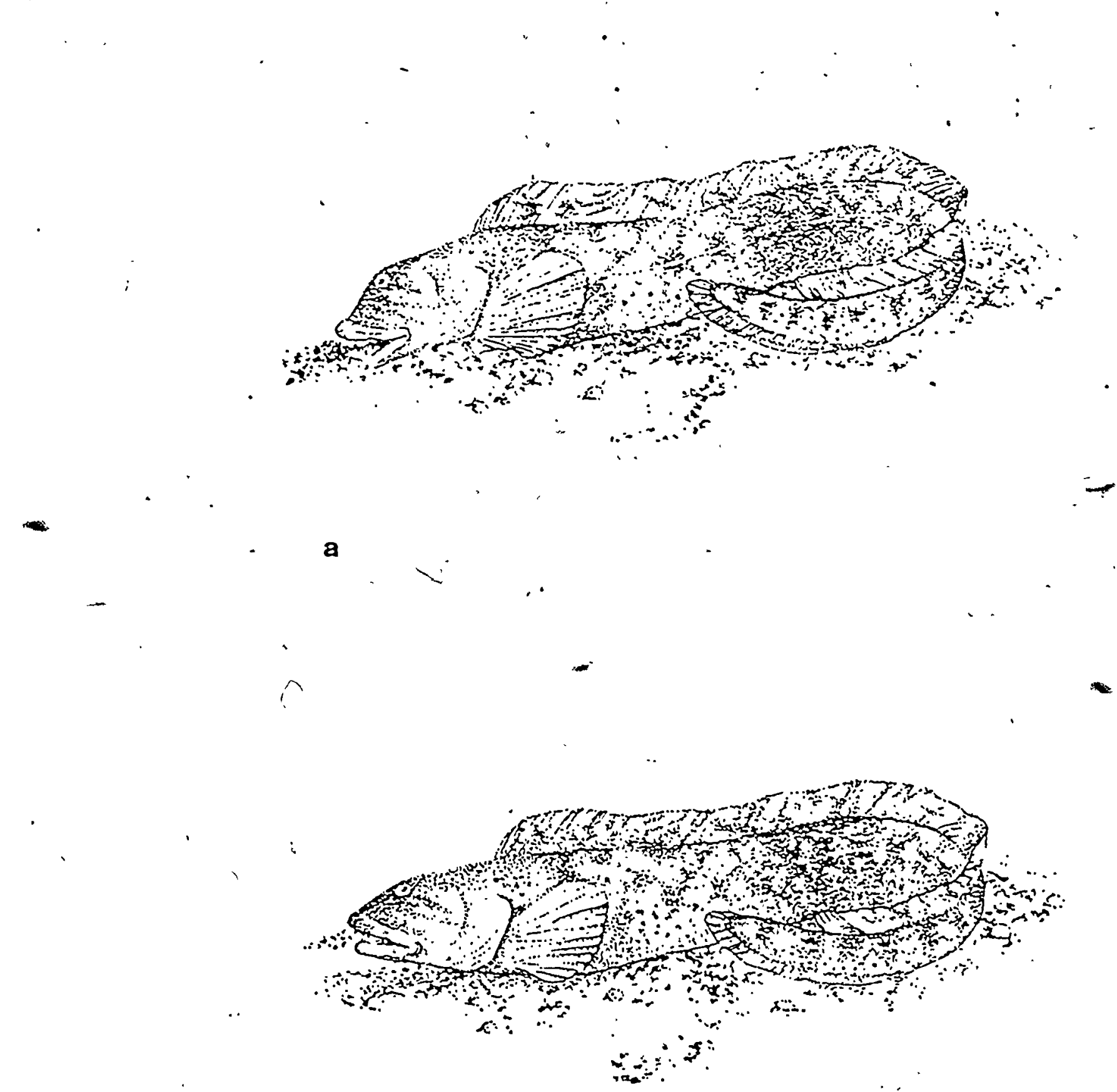

b 
This study. serves to re-emphasize the importance of sight for feeding in winter flounders (Olla et al 1969). Thelr wide field of vision is well suited for the detection of moving food (natural or prèpared). Each feeding advance is directed at an individual prey and not at a portion of the substrate. Other flounder, including Platichthys filesus (Moore and Moore, 1967), Paralichthys dentatus (01la et al 1972), and Pleuronectes microcephalus (Steven, 1930) also rely to a great extent on eyesight for feeding. This has been used to explain their greater activity during the day and their attraction to moving objects.

In contrast, ocean pout showed no stronger response-or abllity to detect moving than stationary food. Prey detected on the bottom were consuned but many potential prey were missed. Slow swimming speeds (Beam1sh, 1966) and apparent poor maneuverability when the tall is not colled while on the bottom indicate that ocean pout are not adapted to pursue moving prey, a process that requires good sight. An alternate strategy, employed by $37 \%$ of the ocean pout observed, involved folding the lower lip outwards to permit the fish to scoop up mouthfuls of sediment. Zoarces viviparus (Zoarcidae) takes mouthfuls of vegetation and sand in a simflar manner (Blegvad) while seeking mollusks.- The subsequent sorting of benthos within the mouth probably requires sensory strucțures on the lips and in the mouth. Iwal (1963) reports the presence of taste budits and other sensory structures on the 1ips, barbels and gill rakers of Plotosus anguillaris. He suspects they play a major role in selecting food after it has entered the mouth.

Using sight or hearing, ocean pout detected disturbances in the sediment caused by flounder digging in. Although the ocean pout were never observed feeddng during this activity, they may be attracted to any 
disturbance at the bottom that might expose benthic prey.

Di rect comparison between the natural diet of the two predator species and the relative utilization of food in the laboratory was impossible because there was no accurate way of estimating what oprey items were consumed by the ocean pout when they took mouthfuls of benthos.

The development of techniques to feed more efficiently on non-mobile prey within the sediment may partially explain the predominance of bivalves and sedentary polychaetes in the natural diet of the ocean pout. (Fig. 2; Table 1). Visual feeders that respond to moving prey, including the winter flounder, are more efficient at/eating polychaetes, amphipods and the common epibenthic fauna (decapods and nekton) than on bivalves (Tyler, 1972). This may éxplain observed interspecific resource partitioning: However, if winter flounder take a significant number of bivalves by renoving the viscera from the shell before swallowing, a count of shells in the stomach will underestimate the total number of animals consumed. In this case a viscera count would be more acçurate than a shell count, if the viscera could, be keyed to the required taxonomic level reliably. Several researchers have observed nipped off bivalve siphons in the stomach contents of winter flounders (Tyler 1971; Woodin pers. comm.). Presumably this behaviour is a method for hàdling prey too large to be consumed whole. The extra handling time would, however, reduce the prey's overall value as à food source. Fre work should consider the effect of fish size and food size on handing time. 



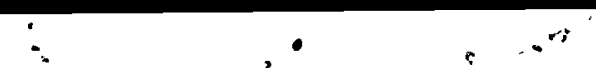


and D.J. Randall, eds.), Vol. 8, p. 71-119. Academic Press, New York. IWAI, T. 1963. Taste buds on the g111 rakers and g11l arches of the sea catfish, Plotosus anguillaris (Lacepede). Copeia 2: 271-274.

KRUUK, H. 1963. Diurnal periodicity in the activity of the common sole, Solea vulgaris Quensel. Neth. I. Sea Res. 2: 1-28.'

MOORE, J.W., AND J.A. MOORE. 1976. The basis of food selection in flounders (P1atichthys flesus), in the Severn Estuary. J. Fish Biol. 9: $\quad 139-156$.

$\because$

OLLA, B.L., C.E. SAMET, AND A.L. STUDHOLME. 1972. Activity and feeding behaviour of the summer flounder (Paralichthys dentatus) under s. controlled laboratory conditions. Fish. Bull. 70: 1127-1136.

OLLA; B.L., R. WICKLUND, AND S. WILK. 1969. Behaviour of yinter flounder in a natural habitat. Trans. Am. Fish. Soc. 98: 717-720. STEVFAN, G.A. 1930. Bottom fauna and the food of fishes. J. Mar. Biol. Assoc. U.K. New Service 16: 677-707.

STICKNEY, R.R., D.B. WHITE, AND D.B. MILLER. 1973. Obs̄ervätions on fin use in relation to feeding and resting behaviour in flatfishes (Pleuronectiformes).. Copeia 1: 154-156.

TYLER, A.V. 1971a. Surges of winter flounder, Pseudopleuronectes americanus, into the intertidal zone. J. Fish. Res. Board Can. 28: 1727-1732.

- TYLER, A.V. 1971b. Monthly changes in stomach contents of demersal fish In Passamaquoddy Bay, N.B. Fish. Res. Board Can. Tech. Rep. No. 288, $150 \mathrm{p}$.

TYLER, A.V. 1972. Food resource division among northern, marine, demersál fïshes." J. Fish. Res. Board Can. 29: 997-1003. 


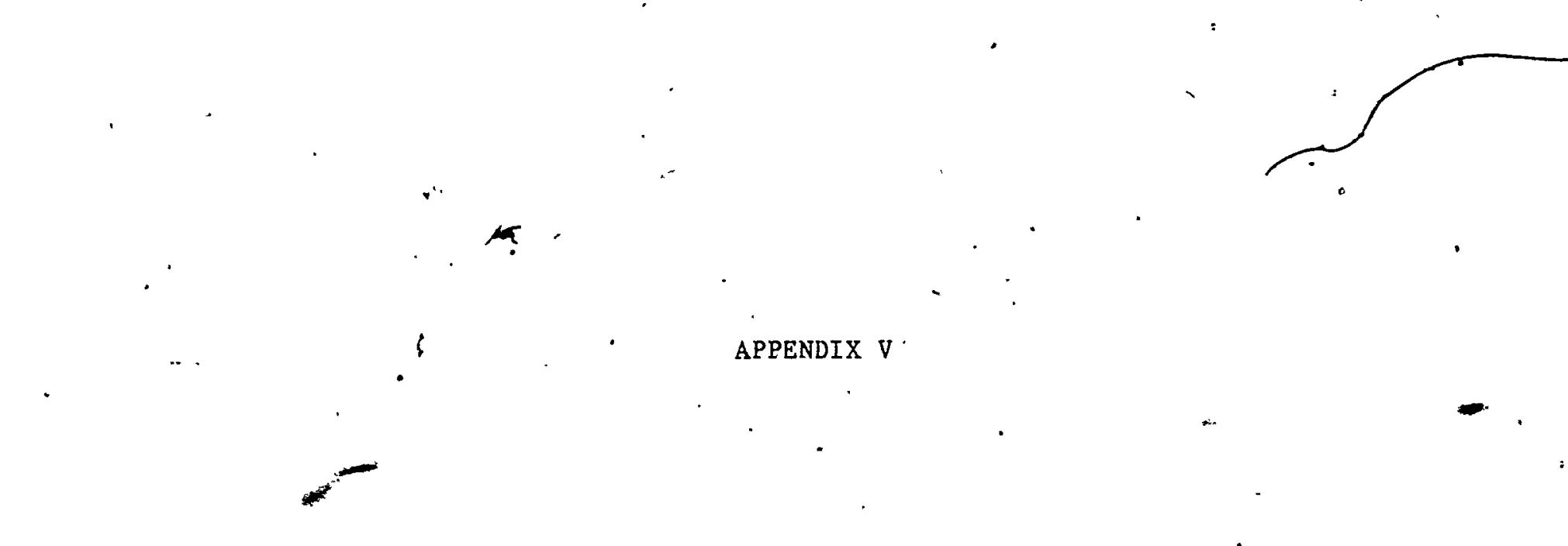

Redundancy in Environmental Variables

J. STEVENSON MACDONALD

and

R.H. GREEN

Deparitment of Zoology,

University of Nestern Ontario,

London, Ont. N6A 5B7 -

9 


\section{INTRODUCTION}

In an effort to identify dominant or imporfant prey species, researchers of animal diet have used several types of measurements. They include numerical abundance, volumes or weights, percent frequency of occurrence and caloric value (revlewed by Hynes 1950; Berg 1979; Hyslop 1980). Each measure was developed to fulfill a different purpose. '-

Numerical abundance measures reflect the process of density-dependent prey acquisition by predators and thus provide insight into feeding behaviour. They may have an advantage if data are being collected in an environment where weigh scales won't work (eg. some research vessels) or if the researcher is not back-calculating original weights.or volumes from taxonomic measures of digested prey (ivindell and Bowen 1978).

Volume or weight measures reflect prey species nutritional value and should be used when prey spectes are too numerous to be counted (RIchards 1963). Ellison (1978) has noted the importance of using actual caloric value as a measure of importance. Caloric values were not avaliable for the prey specles in this study but we suspect they would be highly correlated with the other measurement types. Feinsinger et al (1981) has found caloric methods to be the least approprtate in avallabllity vs. use studies as consimers do not choose resources foule by joule but rather item by 1 tem.

Percent frequency of occurrence gives an indication of prey species variability in predator diets. Frost (1977) has found percent occurrence. measures to be particularly appropriate when there are few food categories. 
Different measurement $\overline{\mathrm{E}}$ ypes are usually assumed to contain information Independent of each other (Hyslop 1980). - To avold information loss several methods have been developed to combine two or more measures. - Hyñes (1.950 - points method), and Hureau (1969 - in Berg 1979) create Indices that combine numerical and volumetric measures. Pinkas (1971) and Prince (1975) combine percent numbers, volumes, and occurrence 10 to a single index (index of relative inportance - ÍkI). These indices are based on an equal contribution by each type of measure.: Cailliet (1976), Hulberg and Oliver (1978) and Hacunda (1980) have used Pinkas' IRF successfully. Callilet, Hulberg and oliver use the three measurement types to define rectangular areas which are compared among prey specles and among predator species.

Compound indices are not exclusive to dletary research. Numbers and weight have been used to describe numerically dominant specties in marine benthic samples by E11is and Conlan: (1979). Curtis and Mcintosh (1951) combine density, frequericy and dominance estimates to measure plant n

-species importance in an upland forest in Wisconsin.

This note addresses the question of data redundancy that may occur among three measurements that are often applied to rank prey spectes importance. It may not be necessary to combine all measures into one index. One measure may describe most of the information in a data matrix.

\section{MATERIALS AND METHODS}

The data were collected as part of a study of spatial and temporal varlation in fish diet in the lower Bay of Fundy region, N.B., Canada 
$\left(45^{\circ} \mathrm{N}, 67^{\circ} \mathrm{W}\right)$. This is now being prepared for publication. Three hundred and ninety seven stomachs from five spectes of fish' (Pseudopleuronectes americanus - winter flounder, Hippoglossoides platessoides - plaice, Gadus morhua - cod, Macrozoarces americanus - ocean pout and

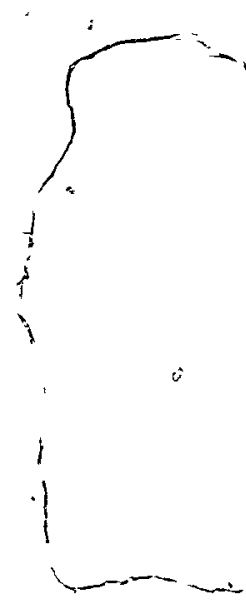

Glyptocephalus cynoglossus - witch flounder) were collected from two Sites at seven times over a perlod of one year (1979-80). Stomachs were . refoved immediately after capture and immersed in $10 \%$ formalin. They weye later transferred to $70 \%$ ethanol. Two hundred and seventeen prey species were identifled. Numerical abundances and blotted wet weights of 'each prey in each stomach were stored in matrix.format on a CDC-Cyber 170 computer at the University of Western Ontario. A FORTRAN program created a data file of mean number, mean welght and percent occurrence of three prey species (Ninoe nigripes - polychaete, Leptocheirus pinguis amphipod, Yoldia sapotilla - bivalve) in each fish specles caught at each site and time. The program also performed Taylor's power law (E1liott 1977 ) on the numbers and weights to transform them in a way that best removed the dependence of the varlance on the mean. The percerit occurrence datia were treated using an arcsine transformation for the same reason (Sokal and Rohlf 1973). The transformed data were analysed separately for each prey species using principal component analysis (FACTOR - SPSS) to determine the amount of variation in the data that was shared among the measurement variables. This process was repeated after removal of the added correlation caused by cases (fish at each site and time) where all three measures were zero. 


\section{RESULTS}

- Numerical abundance data required efther a square root or a log $(X+1)$ transformation. This is consistent with the literature (Marriott 1974, Green 1980). Transformations for welght data were less predictable as each prey specles required a different treatment under Taylor's power law (Table 1). The first peincipal (PC) component described a large portion of the variation whether or not groups with zero values were included - (Table 2). Ali three measurement variables loaded heavily on the first principal component axis'and were highly correlated with each other Fabie 3).

4

DISCUSSION

It is often desirable to reduce numbers of variables (see discussion In Green 1979). Lárge numbers of variables require extra work to collect and analyse, and they Increase sensitivity to violations of assumptions. in multivariate analyses. In many cases the additional information gained decreased rapidly.as more yartables are included (Kaesler et al 1974). The high posifive loadings on the first PC demonstrate that any one of the three variables in this study w11l adequately describe prey species importance regardless of the definttion of importance. "This avolds the difficulties involved in interpretation. and statistical analysts of compound" Indices (Green 1979). 

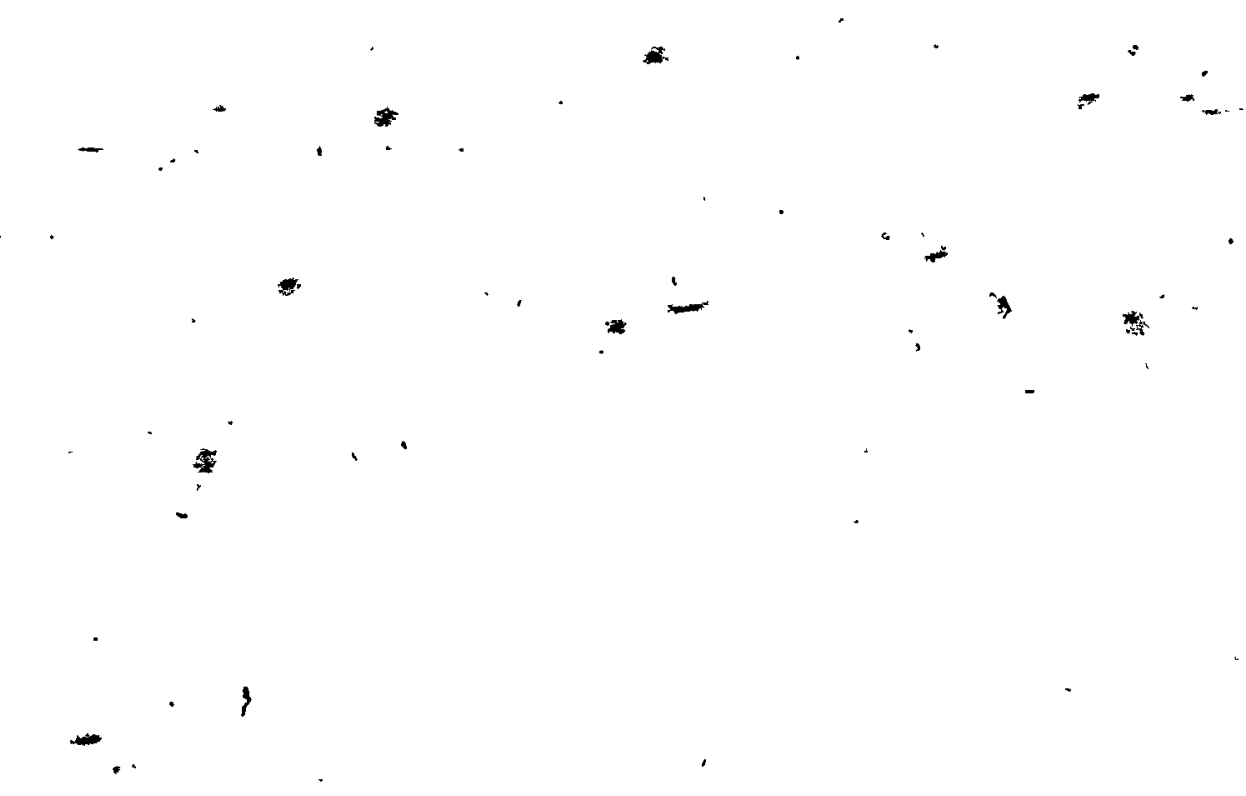

1

$\therefore$

*

244 



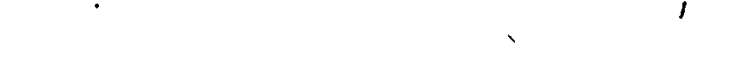

$\therefore$

$\therefore$

TABLE V - 2. Amount of variation accounted for by the first principal component of the analysis on each species. Runs were made.with and without the added correlation caused by cases where all 3 measures were zero.

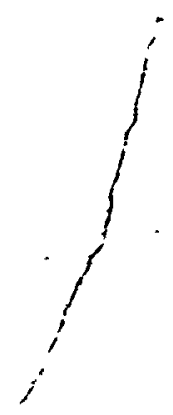

1 



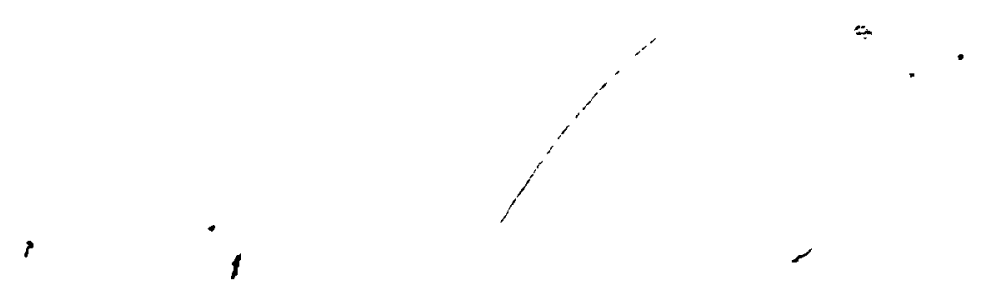

TABLE V - 3. Variable loadings on the first 3 principal components of each species. Correlation coefficients associated with each spectes are also included.

0 


\section{$\Theta$}

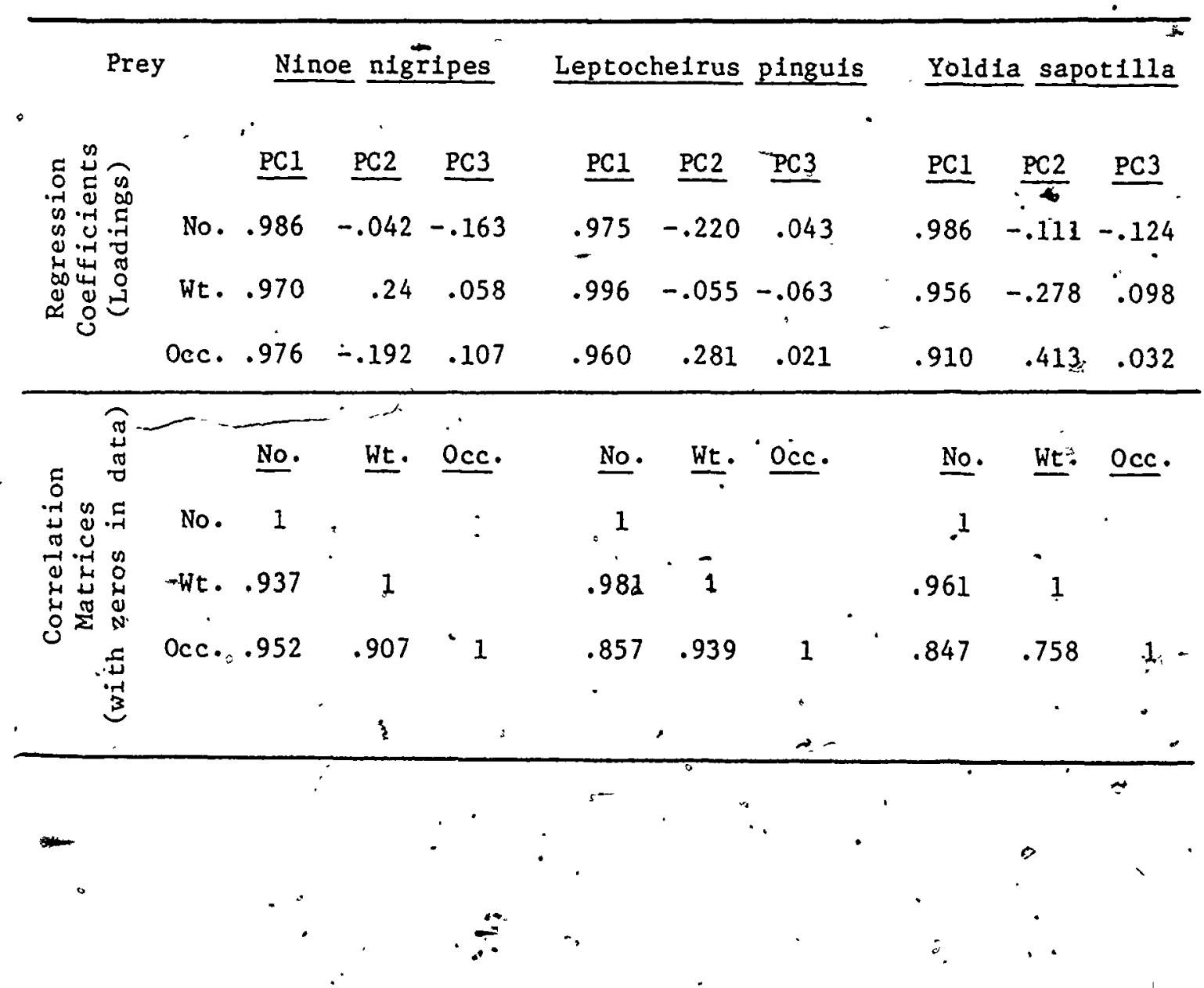




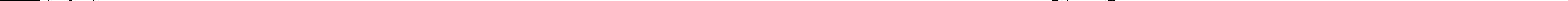


BERG, J. 1979. Discussion of methods of investigating the food of fishes, with reference to a preliminary study of the prey of Gobiusculus flavescens (Gobildae). Marine Biology 50: 263-273, CAILLIET, G.M.: 1976. Approaches to the feeding ecology of fishes, p. 113: In:C.A. Simenstad and it.J. Lipovsky [ed.]: Fish food habit studies; Ist' Paclfic northwest technical wo hikshop. 'Proceedings. University of Wash., Wash.

CURTIS, J.T. and R.P. McINTOSH: 1951. An upland forest continum in the prairle - forest border region of Wisconstn. - ${ }^{-E c o l . ~ 32: ~ 476-496 . ~}$ ELLIOTT, J.M. : 1977. Some methods for the "statistical analysis of samples' of benthic. Lnvertebrates, 2nd sed.' Freshwater Blological Assoc:, Sclentific . Publication $25, " 160$ pp:

ELLTS, D.V. AND K.E. CONLAN. "1979. Defining species" associations for pollution assessment. Canadían Reseàrch 12: 15-19.

ELLISON; J.P. 1978." "The use of disctiminant analysis in the study of fish food habits, p. 80-84. In S.J. Li povsky and C.A.' Simensitad C. [ed.]. Fish food habịt studies, 2nd Paclfic northwest technical workshop. Proceedings. University of Wash., Wash.

FEINȘ́INGER, R., E.E. SPEÁS AND' R'.W. POOLE. 1981. 'A simple measure of niche breadth. 'Ecol: 62(1): $27-32$.

FROST, W.E. 1977. The fqod 'of Char Salvelinus willughibil (Gunther) In Windermere. J. Fish Bioi 11: 531-547. GREEN, R.H. " 1979. Sampling design and statistical methods for environmental biologists. John willey, Toronto, ont. 257 pp. HACUNDA, J.S. 1979. Food resource partitioning by a demersal fish 
"community in.a.coastal area of the Gulf of Maine. M.Sc. Thesis. - University of "Maine, 138 pp.

HULBËG, L.W. AND J.'S. OLIVER. 1978, Prey avaliability and the diets of two co-occurring flatfish, p. 29-36. In S.J. Lipovsky and C.A. Simensted [ed.] Fish food habit studies, 2nd Pacific Northwest technical workshop:-Proceedings. University of Wash., Wash.

HYNES, H.B.N. 1950. The food of freshwater 'sṭicklébacks (Gasterasteus aculeatus and Rygosteus pungituis) with a review-of methods used in studies of foods of fishes. J. Animal Ecol. 19(1): 36-58.

HYSLOP, E.J. 1980. "Stomach content analysis - a review of methods and their application. J. Fish Bial; 17: 411-429.

KAESLER; $: \dot{R} . L ., j$ J. CATRNS,"Jr. AND J.S. CROSSMAN. . 1974." Redundancy in data 'from stream surveys. Water Rés. 8: 637-642.

MARRIC F.H.C. $1974^{\circ}$ The interpretation of multiple observations. Af .rilic Press, New York, N.Y., 117 pp.

PINKE: Albacore, bluefto tuna and bonito in California waters. Fish Bulli:. Calif: 152: 1-105.

PRINCE, E.D. 1975. Pinnixid crabs in the diej of young of the year copper rockfish (Sebastes caurinus). Trans. Am. Fish., Soc. 104: 539540 .

$\therefore$ RICHARDS; S.W. 1963. The demersal fish populations of Long Is land - Sound. III. Food of the juveniles from a mud locality: $\dot{B} u 11$. Bingham -.. Oceanogr. collect. "Yale U. 18: 73-93.

- SOKAL, R.R. AND R.J. ROHLF. 1973. Introduction to Biostatistics. W.H. Freeman, and Co. San Francisco, 368 pp. WINDELL, J.T. AND BOWEN. 1978. "Methods for. study of fish diets, p. 219- 
226.

gan in freshwater. :

sor assessment of fish production Oxford.

Blackwell, Scientific Publications IBP handbook 3,

$5^{\circ}$
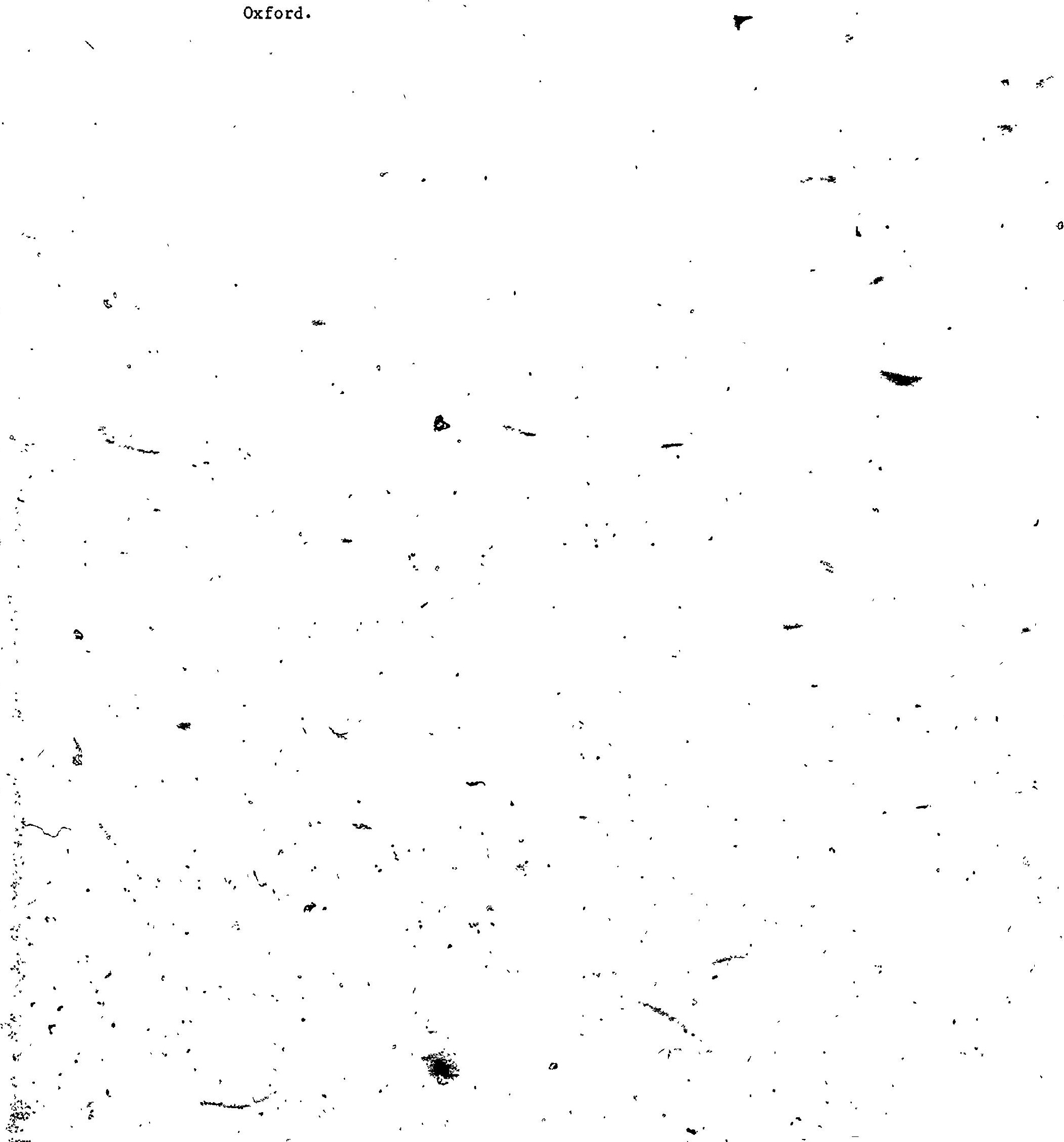
List of the 217 variables (prey or potential prey) collected using ali sampler types at both sites and all times. Each item is categorized by phylum. Numbers in brackets indicate number of those items collected during the entire sampling period. A total of 23,534 prey were corilected and identified. Species marked with an '*' are varlables of the 'reduced data matrix used for the multivariate statistical analysis of food habits.

Crassification is based on Gosner (1971). for the phyla Cnidaria, 'Rhynchocoela" and Echinodermata, Goșner, and Leim and Scott (1966) for" phỵlum Choŕdata, Brinkhurst et al. (1970), Dadsweil (pers. comm.), Roff (1978) and Smith (1964) for phylim Arthropoda, Gosner and Abboti (1974) for. phylum Molluska and Appy (1980) and Linkletter (pers. comm.) for phylúm Annelida. 
Phylum-Cnidaria (498)

Class Hydrozoa

Corymorpha perdula Peachia parasitica

Class Anthozoa

Edwardsia elegans

Bunadact1s stella

Phylum Rhynchocoela (45)

Class Anopla

* Micura affinis Cerebratulus Iacteus

Class Enopla

Amphiporus spp.

Tetrastemma spp.

Ototyphlonemertes pellucida

Phylum Molluscä $(4,664)$

Class Aplacophora

Chaetoderma nitidulum

Class Polyplacophora

Ischnochiton ruber

Class Gastropoda

Subclass Prosobranchia

Puncturella noachina

* Lunatia herós

L. pallidä

L. triseriata

Cólus stimpsoni

Colus obesus

Colus pygmaea

Cructbulum striatum

Propebela turricula

Trichotropis borealis

* Alvania pelagica

Natica pusilla

Natica clausa.

Mitrella dissimilis

Neptunea decemcostata

Oenopota decussata

Solariella lamellosa

unidentified gastropod

Subclass Oplsthobranchia Diaphana minuta

* Cylichna alba

Class Scaphopoda

* Dentalium entale

Class Pelecypoda

Subclass Protobranchia * Nucula proxima

.. $\quad *$ N.otenuis

* N. delphinodonta

* Yoldia sapotilla

* Nuculana tenuisulcata

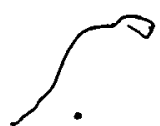




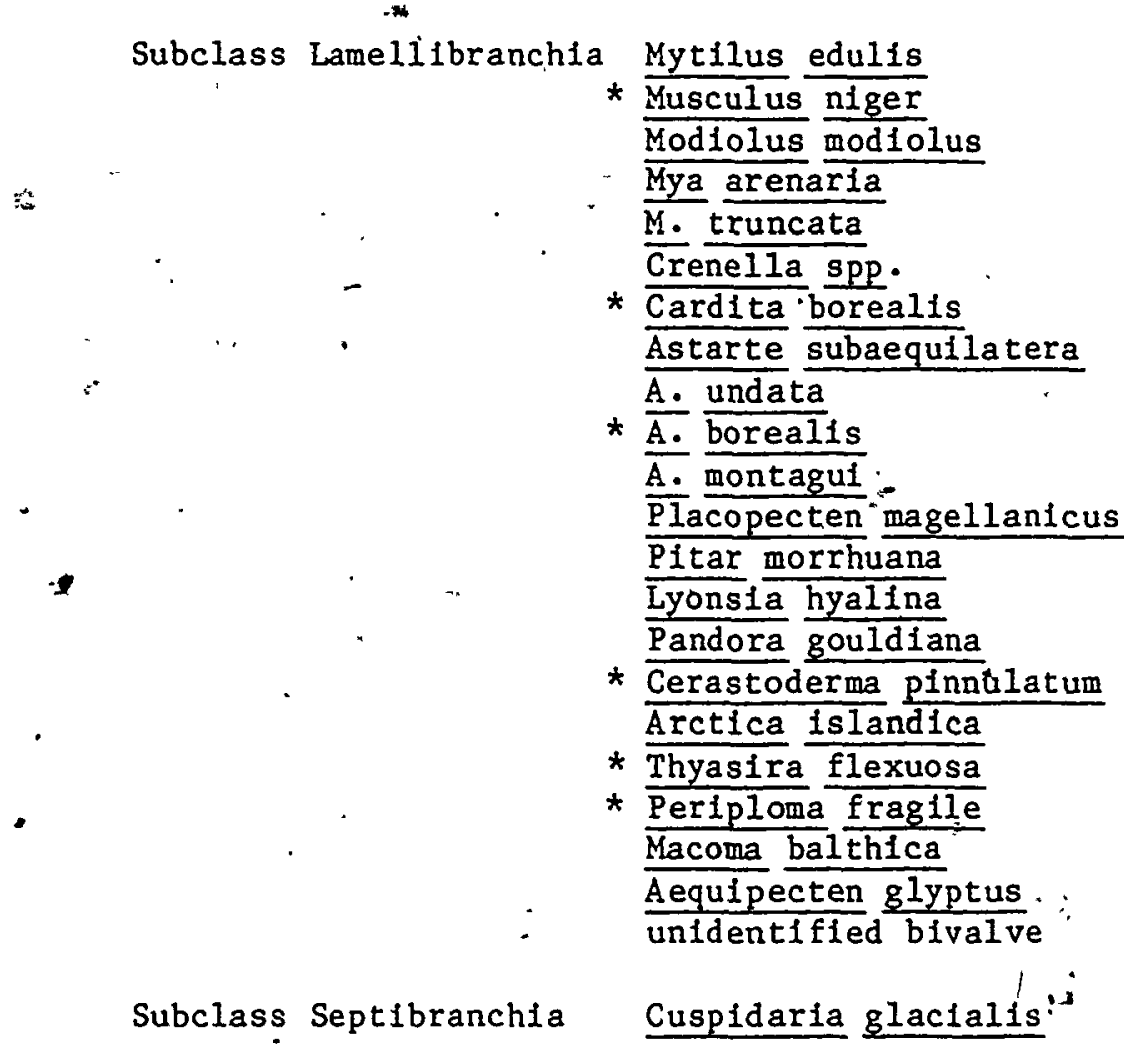

螘

$$
\text { Class Cephalopoda }
$$

Ilex 11 lacebrosus

Phylum Annelida $(8,274)$

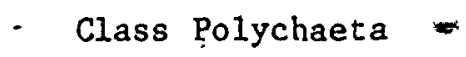

Subclass Errant1a

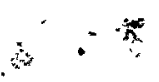

* Nepthys inciša

* Lumbrineris fragilis

L. tenuis

L. latre111

Lumbrinidae family

Drilonereis magna

* Ninoé nigripes

* Goniada maculata

* Phy1lodoce groenland1ca

P. maculata

- Teris virens

* Harmöthoe extenuata

* H. imbricata

Harmb thoe spp.

Eteone trilineata

* E. longa

E. flava

Eteone spp.

Paranaltis speciosa

* Ammotrypane aulogaster

Goniada norvegica

Ophloglycera gigantea

G1ycera spp. 


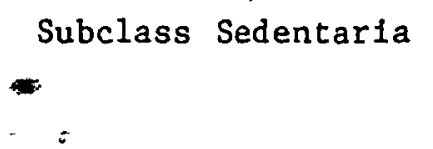

is

* Sternaspis scutata

* Terebellides stroemi1 Capitella capitata

* Rhodine loveni

* Melinna cristata

* Owenia fusiformis

* Tharynx acutus

* Potamilla neglecta

* P. reniformis

* Praxillella praetermisa P. gracilis

* Scalibregma inflatum

* Brada villosa

* Euchone rubrocincta.

* Ampharetidae family Pherusa plumosa

* Syl1is cornuta Trichobranchus glacialis Laonice cirrata Cossura longocirrata Clymonella zonalis

* Aricidea quadrilobata

* Chaetozone setosa

* Aphrodita hasata Sabellaria vulgaris

* Pherusa affinis Pherusa aspira Spirorbis spp. Brada viliosa Brada granosa Nicolea venustula Heteromastus filiformis Cistena granulata.

- Diplocirrus hirsutes

* Maldanidae family Unidentified worm

Phylum Arthropoda (9814) Subphylum Pycnogonida Nymphon grossipes

Subphylum Mandibulata Subclass Copepoda Order Cumacea Eudorella emaginata E. truncatula

* E. pusilla - E. hispida Diastylis rathkel

* D. quadrispinosa

* D. cornulfer

* D. sculpta D. polita Diastylis sp.

* Leptosty1 1s long imana 
order Cumacea (Cont'd.)

Order Isopoda

Order Amphipoda

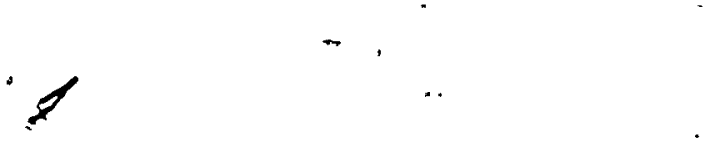

6

*

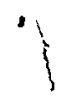

* Petalosarsia dedidis

Campylaspis rubicunda C. affinis

Leucon americanus

* Edotea montosa Idotea phosphorea

* Synidotea nodulosa Chiridotea laevis Ptilanthura tenuis Munna fabricil Calathura branchiata

* Leptocheirus pinguis

* Haploops fundiensis Casco bigelowi. Aeginina longicornus Erichthonius rubricornis

* E. difformis

* Unciola leucopis

* U. Irrorata

* U. Inermis Unciola spp.

* Stenopleustes inermis

* Orchomonella minuta Calliopius laeviusclus Byblis gaimardi.

* Maera danae M. 1oveni

* Syrrhoe crenulata Argissa hamatipes Hippomedon serratus

* H. propinquis Anonyx sarsi

* A. lill jeborgi Oedicerotidae family

* Westwoodilla caecula Monoculodes edwards1 Ampelisca aequicornus A. macroce phala Pontogeneia Inermis

* Dyopedos monocanthus

* D. porrectus Prôtomedia fasiata Parathemisto compressa Paroediceros 1ynceus Phot 1s macrocoxa

* Tmetonyx clcada Aceroldes latipes phoxocephalus holbolli Phoxichilidium, femoratum Acanthonotozoma serratum

* Harp1na proplnqua 
Order Amphipoda

(Cont'd.)

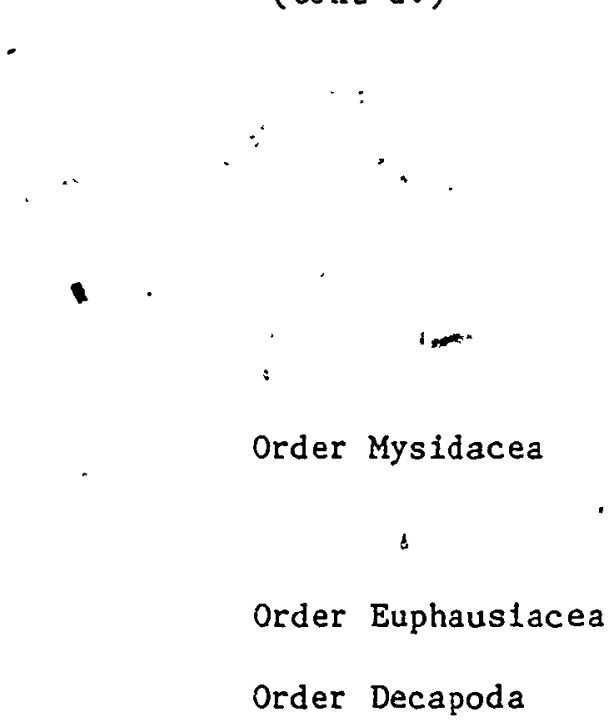

-

Phylum Echinodermata (155)

Class' Holothuroidea

Class stelleroidea

Phylum Chordata (83)

- Class Ascidiacea

Class Osteichthyes :

Additional Vardables
Ischyroceros angulpes

Stenopleustes gracilis

Paradulichia typica

Gammaropsis melanops

Metopella angusta

Caprella septemtrionalis

Melita dentata

Mayerella limicola

Pleurogonium spinossimum

Corophium bonelli

unidentified amphipod

Erythrops erythrophthalma

Neomysis americana

Mysis stenolepis

Meganyctiphanes norvegica

Pandalus borealis

P. montagui

Cancer 1rroratus

Pagurus spp.

Crangon septemspinosa

Eualus pusiolus

Molpadia oolithica

Gitenodiscus crispatus

Oph1ura sarsi

* Amphipholis squamata

Boltenfa ovifera

* Mogila spp.

Merlucclus bilinearis.

Clupea harengus

Pseudop Ieuranectes.

americanus

Osmerus mordax

* unidentified fish remains

inorganic sediment 

.

5

FORI

FORTRAN PROGRAM TO RUN ON THE CYBER 170 THAT CALCULATES SHORIGINS AND

C IVLEVS ELECTIVITY INDICES.PROGRAM ALSO CALCULATES MEAN NO. OF EACH PREY

C ITEM THAT WAS FOUND IN EACH PREDATOR SPECIES STOMACHEAND PERCENT FREQ.

$C$ OF OCCUR ENCES. DATA IS ENTERED FROM SEPERATE FILES; EACH FILE CONTAINS

C DATA FROM A SEPERATE PREDATOR SPECIES OR BOTTOM GRAB. INFORMATION ABOUT

C THE NO. OF FISH IN EACH FILE AND THE NO. OF VARIABLES IN ALL FILES IS

C ENTERED ON A SEPERATE CARD AT THE END OE THE PROGRAM.

$\mathrm{C}$

C

PROGRAM NAME (INPUT, OUTPUT, TAPE5 = INPUT, TAFE6 =OUTPUT, TAPET1, TAPE12, X.TAPE13, TAPE14, TAPE15, TAPE 16)

DINENSION $X(10,217,6), \operatorname{SUM}(217), N(6), \operatorname{GSUM}(6), \operatorname{SUM} 1(6), O C C(217)$,

$¥ \operatorname{PSUM}(217), \operatorname{PSUM} 1(217), \mathrm{E}(217), \mathrm{C}(217), \operatorname{MOC}(217), \mathrm{MN}(217), E(217)$

REAL SUM, PSUM, SUM1,MN,MOC, GSUM, X, E, C, F, OCC

INTEGER P, I, J, O, N, K, IU:M

READ ${ }^{*}, \dot{P}, N, L$

DO $500 \mathrm{~K}=1, \mathrm{~L}$

$\operatorname{IF}(N(K) . E Q .0)$ GO TO 500

IF(K.EQ.1) PRINT 11

11 FORMAT (" GRAB",/)

IF(K.EQ.2)PRINT' 12

12 FORMAT (" COD", /)

IF (K.EQ.3) PRINT. 13

13. FORMAT (" OP" $/ 1$ )

IF(K.Q. 4 )PRINT 14

14 FORMAT ("WF",/)

IF (K.EQ.5) PRINT 15

15 FORMAT (" PLAICE",/)

IF(K.EQ.6)PRINT 17

17 FORMAT ("WITCH", /)

$I U=K+10$

$M=N(K)$

DO $10 \quad I=1, M$

$\operatorname{READ}(I U, 16)(X(I, J, K), J=1, \ddot{P})$

16 FORMAT $(3.0(7 \mathrm{~F} 10.5 \%), 7$ F 10.5)

10 CONTINUE

$\operatorname{GSUM}(-K)=0$

$-\operatorname{SUM} 1(K)=0$

DO $30 \mathrm{~J}=1, \mathrm{P}$

$\operatorname{SUM}(J)=0.0$

$\operatorname{OCC}(J)=0.0$,

$\operatorname{MN}(J)=0.0$

$\operatorname{MOC}(\mathrm{J})=0.0$

DO $40 \quad I=1, M$

$\operatorname{SUM}(J)=\operatorname{SUM}(J)+X(I, J, K)$.

IF $(X(I, J, K) . G T . O) O C C(J)=O C C(J)+1$.

40 CONTINUE

$\operatorname{SUM} 1(K)=\operatorname{SUM}(J)+\operatorname{SUM} 1(K)$

$0=\mathrm{J}+19$

$\operatorname{MN}(J)=\operatorname{SUM}(J) / N(K)$

$\operatorname{MOC}(J):=0 C C(J) / N(K) * 100$

WRITE $(6,50) 0, \operatorname{SUM}(J), \operatorname{MN}(J), \operatorname{OCC}(J), \operatorname{MOC}(\mathrm{J})$

50 FORMAT (" SUM, MEAN SUM, OCCURING AND \% OCCURANCES OF VARIABLE ", *I3, 2X, F5. $1,2 X, F 7.3,2 X, F 3.0,2 X, F 7.3$ ? 
262

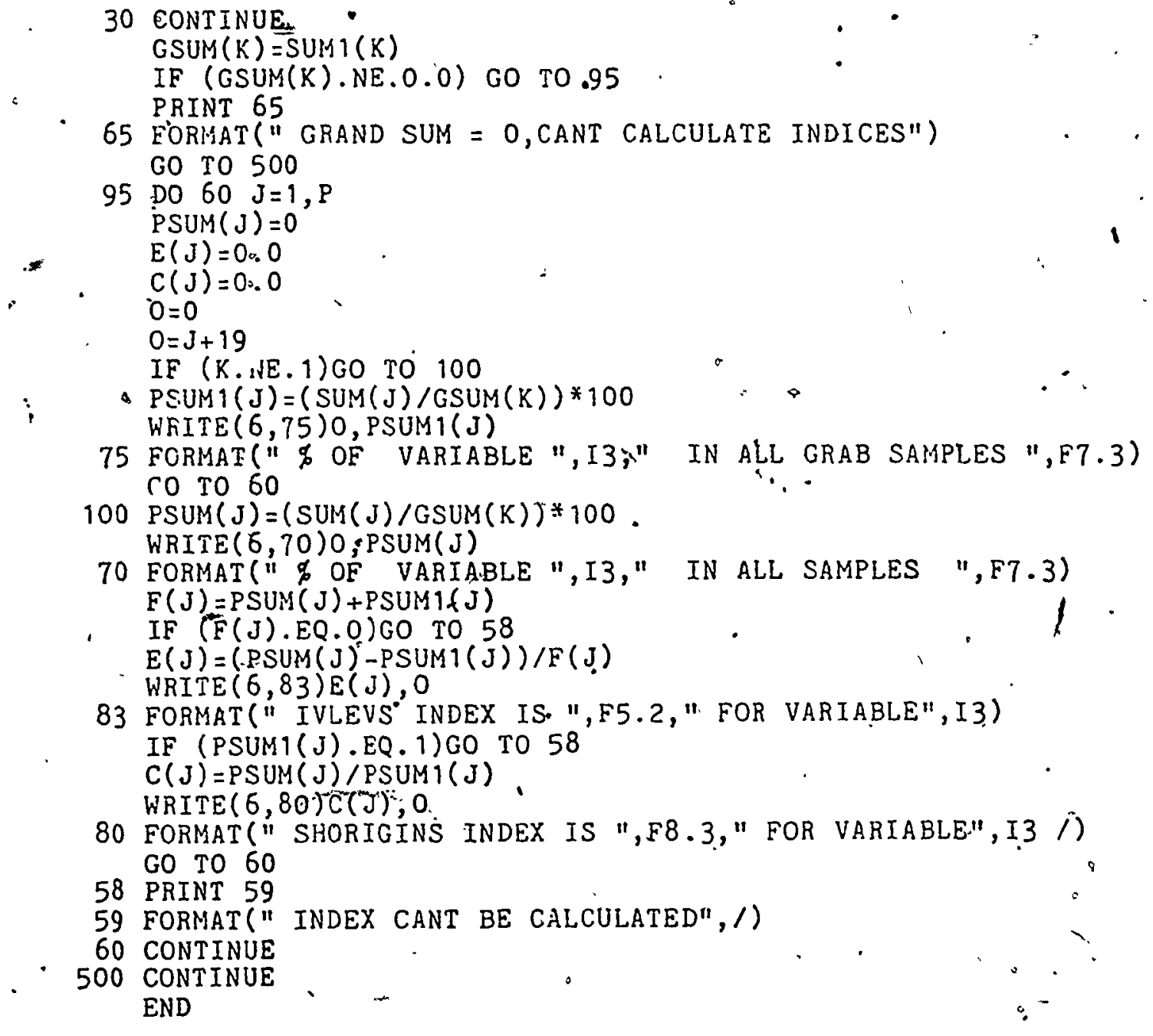



$\therefore$

264

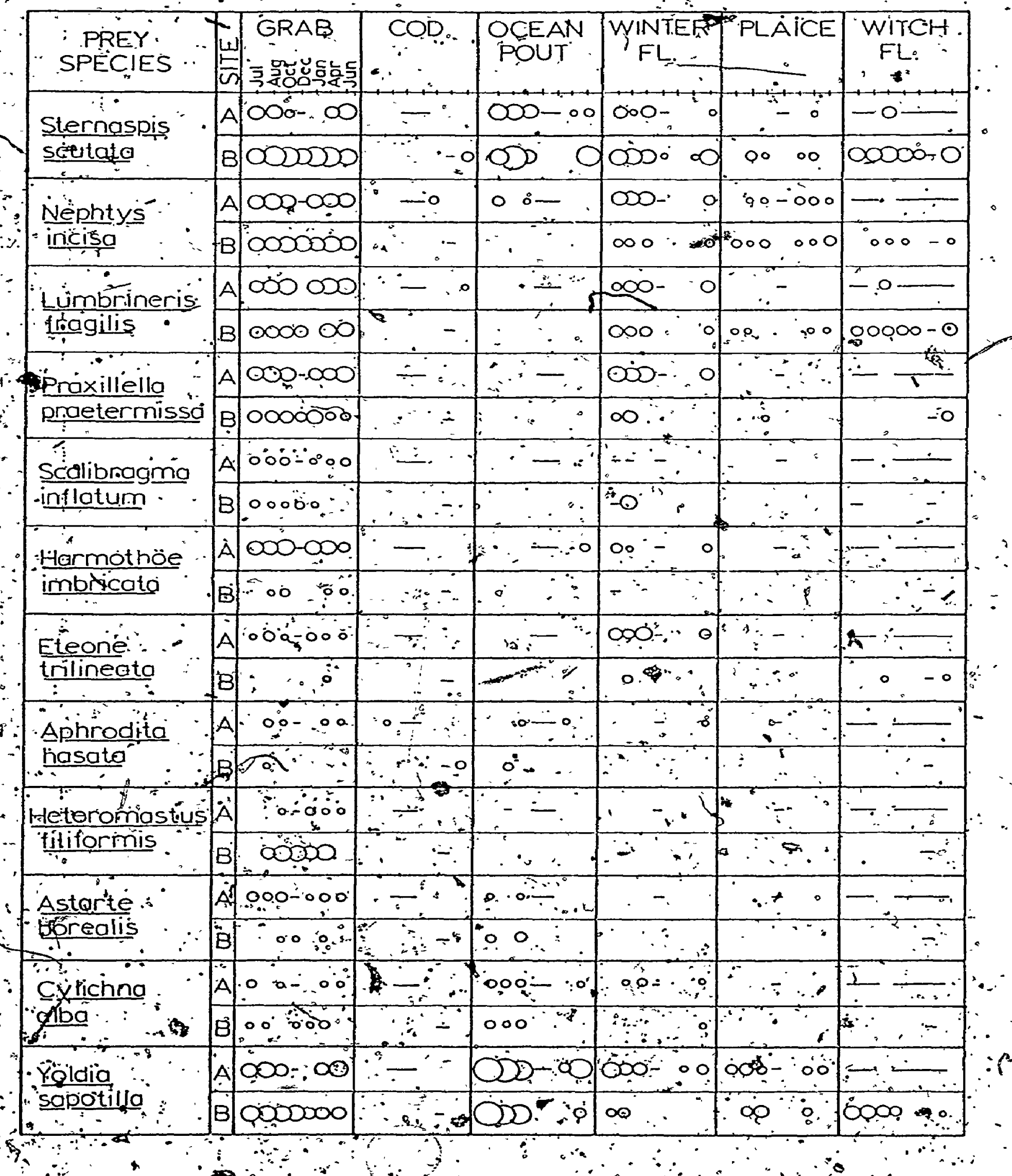




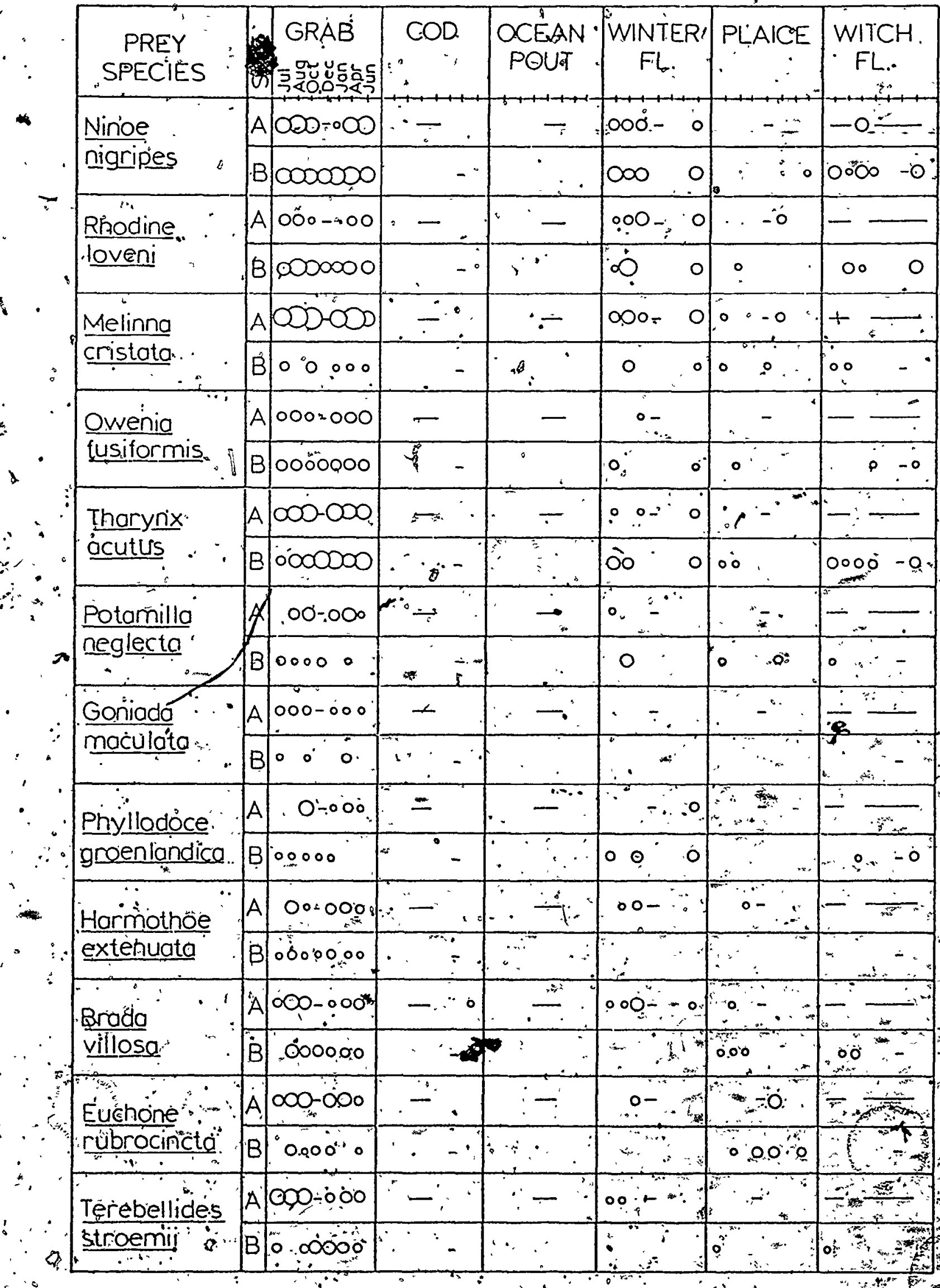

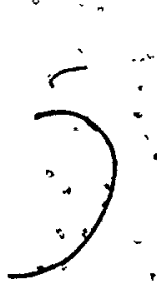

. $1:$ 


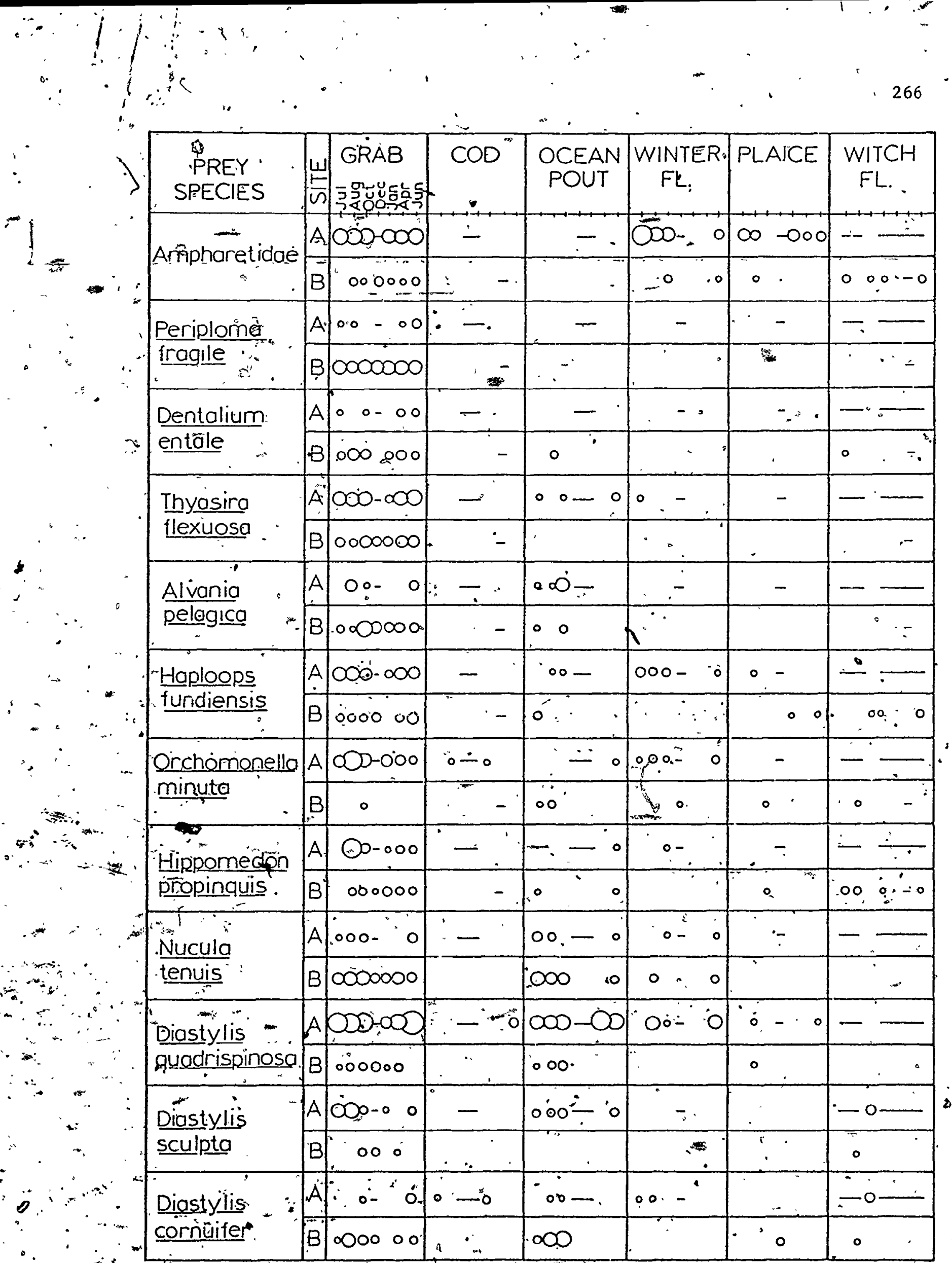




\begin{tabular}{|c|c|c|c|c|c|c|c|}
\hline $\begin{array}{c}\text { PREY } \\
\text { SPECIES }\end{array}$ & $\frac{w}{\omega}$ & 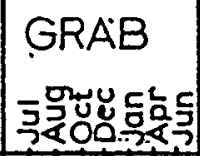 & COD & $\begin{array}{l}\text { OCEAN } \\
\text { POUT }\end{array}$ & $\begin{array}{c}\text { WINTER } \\
\text { FL. }\end{array}$ & PLAICE & $\begin{array}{l}\text { WITCH } \\
\text { FL: }\end{array}$ \\
\hline \multirow{2}{*}{$\begin{array}{l}\text { Nucula: } \\
\text { proximá }\end{array}$} & A & $\infty 00-\infty$ & - & $.00-$ & 00 & $00=$ & 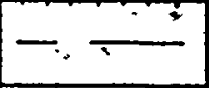 \\
\hline & $B$ & $\begin{array}{llll}0 & 0 & 0 & 0\end{array}$ & - & $\because 0$ & 。 & & -0 \\
\hline \multirow{2}{*}{$\frac{\text { Arctica }}{\text { islandica }}$} & A & $000-00$ & , & $00-0$ & $\circ$ & $\circ \quad-$ & $\div \div$ \\
\hline & $B$ & 0.00 & - & $\infty$ & & 。 &. \\
\hline \multirow{2}{*}{$\begin{array}{l}\text { Cerastodermo } \\
\text { pinnulatum }\end{array}$} & A & $\infty \infty 0-\infty$ & - & $\infty \infty-0$ & .0 & $\circ-$ & $-\div$ \\
\hline & $B$ & 000000 & - & $\infty$ & & & - \\
\hline \multirow{2}{*}{$\begin{array}{l}\text { Nuculana. } \\
\text { tenuisulcato }\end{array}$} & A & $000-00$ & - & $00-0$ & & -0 & $\therefore-$ \\
\hline & B & $\infty \infty 00.00$ & . $\quad-$ & $\infty$ & $\circ$ & 00 & $\circ \quad-$ \\
\hline \multirow{2}{*}{$\frac{\text { Musculus }}{\text { niger }}$} & A & $\mid \begin{array}{lll}0 & 0-0 & 0\end{array}$ & $\therefore$ & $0 \quad-0$ & 0. &. & -- \\
\hline & $B$ & . $\circ$ & $\therefore$ & $\begin{array}{lll}0 & 0 & \\
\end{array}$ & & & - \\
\hline \multirow{2}{*}{$\frac{\text { Cardita }}{\text { borealis }}$} & A & $00-00$ & - & $:-$ & & - & -- \\
\hline & $B$ & & - & & & - & $\therefore \quad-$ \\
\hline \multirow{2}{*}{$\begin{array}{l}\text { Leptocheirus } \\
\text { pinguis }\end{array}$} & A & ONOOD & $\infty-\infty$ & $000-\infty$ & OD 0 & -0 & $=-$ \\
\hline & $B$ & 000 & - & 10 & & 00 & $\because-0$ \\
\hline \multirow{2}{*}{ Casco } & A & $\infty$ & - 00 & $\circ 0-0$ & 000 & $0-0$ & $-0=$ \\
\hline & $B$ & 0000000 & - & $000 \quad 0$ & $\infty$ & $\infty 00 \quad 000$ & 00000 \\
\hline \multirow{2}{*}{$\begin{array}{l}\text { Erichithonius } \\
\text { rubricornis }\end{array}$} & A & 00 & - & - & o. & $\therefore$ & - \\
\hline & $B$ & ○ & - & & 1 & 0 & - \\
\hline \multirow{2}{*}{$\begin{array}{l}\text { Unciola } \\
\text { leucopis }\end{array}$} & A & $\infty \infty 0-\infty$ & $00-0$ & -00 & & $\because 0$ & -- \\
\hline & $B$ & & - & . & o & & - \\
\hline \multirow{2}{*}{$\frac{\text { Unciola }}{\text { irrorata }}$} & A & $100-\infty 0^{\circ}$ & $0-0 Q Q$ & $0-0-\infty$ & 인 & -0 & $\div$ \\
\hline & $B$ & & - & & $\cdot$ & $\circ$ & - \\
\hline \multirow{2}{*}{$\begin{array}{l}\text { Unciola } \\
\text { inermis }\end{array}$} & A & $0 .-00$ & 0 & $=0$ & $\circ$ & $\therefore-.8$ & $-\div$ \\
\hline & $B$ & & - & & & & .- \\
\hline
\end{tabular}




\begin{tabular}{|c|c|c|c|c|c|c|c|}
\hline $\begin{array}{l}\text { P PREY } \\
\text { SPECIES }\end{array}$ & $\frac{w}{\bar{v}}$ & 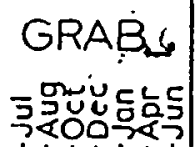 & $\mathrm{COD}$ & $\begin{array}{l}\text { OCEAN } \\
\text { POUT }\end{array}$ & $\begin{array}{c}\text { WINTER } \\
\dot{F L},\end{array}$ & PLAIÇE & $\begin{array}{l}\text { WITCH } \\
\text { FL. }\end{array}$ \\
\hline \multirow{2}{*}{$\frac{M}{\text { norvegica }}$} & A & $00-1$ & $0 \div 0$ & $\longrightarrow$. & {$\left[\begin{array}{c}\cdots+1 \\
-\end{array}\right.$} & -0. & $\div$ \\
\hline & $B$ & & & & - &.$\cdots$ & - \\
\hline \multirow{2}{*}{ Pandalus : } & A & - & $0 \rightarrow$ & - & $-\dot{ }$ & -0 & - \\
\hline & $B$ & & - & & $\therefore$ & & $\cdot \quad-$ \\
\hline \multirow{2}{*}{$\frac{\text { Moera }}{\text { loven }}$} & $A$ & $00-$ & - & 一 & - & & - \\
\hline & $B$ & 0 & - & & & & $-\because$ \\
\hline \multirow{2}{*}{$\begin{array}{l}\text { Dyopedos } \\
\text { monocanthus }\end{array}$} & A & $00-00$ & - & 一 & - & -.0 & $-\longrightarrow$ \\
\hline & $B$ & 00 & - & & 0 & . & $-i$ \\
\hline \multirow{2}{*}{$\begin{array}{l}\text { Eudornello } \\
\text { pusilla }\end{array}$} & A & $0=00$ & - & - &.- & - & $-\square$ \\
\hline & B & 0 & - & $\checkmark \quad$. & & . & $-i$ \\
\hline \multirow{2}{*}{$\begin{array}{l}\text { Maldanidae } \\
\text { family }\end{array}$} & A & $0-0$ & - & $\dot{ }^{-}$ &. .0 & $=0 \quad \therefore$ & $-\cdots$ \\
\hline & $\ddot{B}$ & : & - & 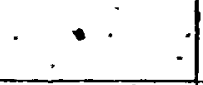 & 。 & 0 & - \\
\hline \multirow{2}{*}{$\begin{array}{l}\text { Amphipolis } \\
\text { squamata }\end{array}$} & $A$ & ogo- 00 & -0 & o $0 \ddot{-}$ & $\infty:-0$ & - -0.00 & -- \\
\hline & $B$ & $0 \quad 0 \quad 00$ & $=$ & - : & . & 0 & - \\
\hline \multirow{2}{*}{$\frac{\text { Nuculá }}{\text { delphinodonta }}$} & A & $\therefore \quad-\because \quad 0$ & $\ldots$ & $\infty-$ & - & : & $-r$ \\
\hline & $B$ & 0000000 & $-i=1$ & - 0. & , & $\therefore$ & - \\
\hline \multirow{2}{*}{$\frac{\text { Harping }}{\text { propingug }}$} & A & ó0-000 & $\div$ &. & - & - & $\div \div$ \\
\hline & $B$ & $0000 \%$ & - & & 8 & $?$ & $\begin{array}{l}0 \\
0\end{array}$ \\
\hline \multirow{2}{*}{$\begin{array}{l}\text { Syrrinoe } \\
\text { crenulata }\end{array}$} & A & $000-\quad 0$ & $\bar{x}$ & $\therefore=$ & $0-$ & $\therefore a-$ & $\operatorname{Sin}$ \\
\hline & B & 0 & $-\cdot$ & $7:{ }^{\circ}$ & & & $\because$ \\
\hline \multirow{2}{*}{$\begin{array}{l}\text { Chaetozone } \\
\text { setosa }\end{array}$} & $A$ & $:-$ & -5 & . & - & . & $-\div$ \\
\hline & $B$ & 000 & $. \quad-$ & & & $\therefore$ & - \\
\hline \multirow{2}{*}{$\frac{\text { Mogula }}{\text { spp. }}$} & A & .0 & $\therefore$ & $00-" 0$ & $.0-\quad 0$ & $:^{3} .-$ & $-\div$ \\
\hline & $\mathrm{B}$ & & $1 \div$ & $:$ & $\therefore$ & $\circ$ & 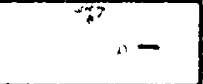 \\
\hline
\end{tabular}


\rfloor

APPENDIX IX

ForTRan program to calculate $95 \%$ confidence ellipses around centroids of any bivariate data. Comment statements (marked " $C$ " in the _left column) have been left in to ald future error searches's.

269

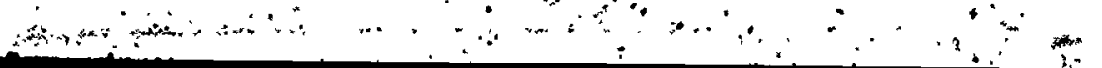




\section{(}

C THIS PROGRAM CALCULATES 95\%.CL ELIPSES AROUND THE CENTR6IDS

- C CALCULATED IN DISCRIMINANT ANALYSIS. THE DATA (THE DISCRIMINANT

C SCORES) ARE INPUT FROM UNIT =1. THE.DATA NEEDNT BE GROUPED. THE

- C USER MaY ENTER the dATA in RANDOM ÓRDER AND. THEN SPECIFY WHICH

C LINES ARE ASSOCIATED WITH EACH CENTROID.HOWEVER THE DATA MUST BE

C IN THO COLUMNS (ONE FOR EACH DISCRIMINANT FUNCTION).K(I) IS DIMENSIONED

C FOR THE NO. OF DISCRIMINANT SCORES. IF THE DATA IS IN GRPS IT CAN

C BE DIMENSIONED TO THE NO. OF GRPS. $M(I)$ AND $N$ ARE DIMENSIONED TO THE-

C NO. OF CENTROIDS. CENTI(I), CENT2(I) ARE DIMENSIONED TO CENTROID NO.

C THIS PROGRAM “WORKS WELL WITH ANY BIVARIATE DATA AS WELL!

$\mathrm{C}$
$\mathrm{C}$

INTEGER J,O,P,S,U, J1

REAL ICRIM2, DCRIM 1, CENT?, CHI

DIMENSION $K(20), M(10), N(30), \operatorname{CENT} 1(6), \operatorname{CENT} 2(6), \operatorname{CLX}(6), \operatorname{CLY}(6)$

$N 1=0$

TYPE 10 .

10 FORMAT ( FTN PROGRAM TO CALCULATE 95\% ELIPSES IN DCRIM ANALYSIS')

OPEN (UNIT $=1$, DEVICE $=$ 'DSK', ACCESS = 'SEQIN',FILE= 'DSDECW. DAT'

OPEN (UNIT $=2$, DEV ICE = 'DSK', ACCESS = 'SEQOUT', FILE= 'ELDECH.DAT' $)$

$O I^{\prime} E N$ (UNIT =20, DEVICE = 'DSK', $A C C E S S=$ 'SEQOUT', FILE= 'WF.DAT')

OP'EN (UNIT $=21$, DEVICE ='DSK', ACCESS = 'SEQOUT', FILE= 'OP.DAT' )

OPEN (UNIT $=22$, DEVICE ' $D S K^{\prime}$, , ACCESS = 'SEQOUT', FILE = 'C.DAT')

O'EN ('UNIT $=23$, DEVICE $=$ 'DSK', ACCESS = 'SEQOUT', FILE='P.DAT')

OPEN (UNIT $=24$, DEVICE ='DSK', ACCESS='SEQOUT', FILE=' 'W.DAT')

OPEN (UNIT $=25$, DEVICE $=$ 'DSK', ACCESS = 'SEQOUT', EILE= 'G. DAT')

15

TYPE 15

FORMAT(: HOW MANY CENTROIDS ARE THERE, $\dot{6}$ MAX.')

ACCEPT $*, J 1$

C TYPE 17

C17 FORMAT ENTER CHI X2 VALUE...FOR 2 DES, 95\% CL X2=5.991')

C

20 FORMAT(' HOW MANY GRPS IS THE DATA ARRANGED IN?')

ACCEPT *, CHI

TYPE 20

ACCEPT * $\mathrm{J}$

TYPE 30

30

FORMAT(" INPUT VECTOR OF GRP'SIZES')

DO $40 \quad I=1, \mathrm{~J}$,

$\operatorname{READ}(5,32) \mathrm{K}(\mathrm{I})$

32 FORMAT (I2)

$\mathrm{U}=\mathrm{U}+\mathrm{K}(\mathrm{I})$

$\because-40 \quad$ CONTINUE

H4 WRIE $(6,44) U^{\circ}$

44. FORMAT (' TOTAL NO. OF DCRIM SCORES FOR EACH DF EQUALS ' 14$)^{\circ}$.

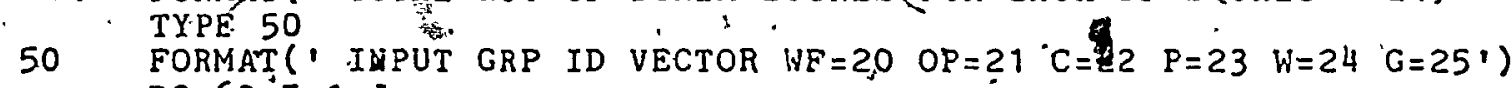

DO $60^{\circ} I=1, J$

60 CONTINUE

C WRITE $(6,61) M(1), M(2), M(3)$.

C61.

FORMAT ( ' I I , 1X, I2, $1 \mathrm{X}, \mathrm{I2})$

DO $55 \quad I=1,30^{\circ}$

$N(I)=0$

5.5. CONTINUE

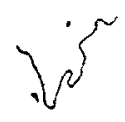




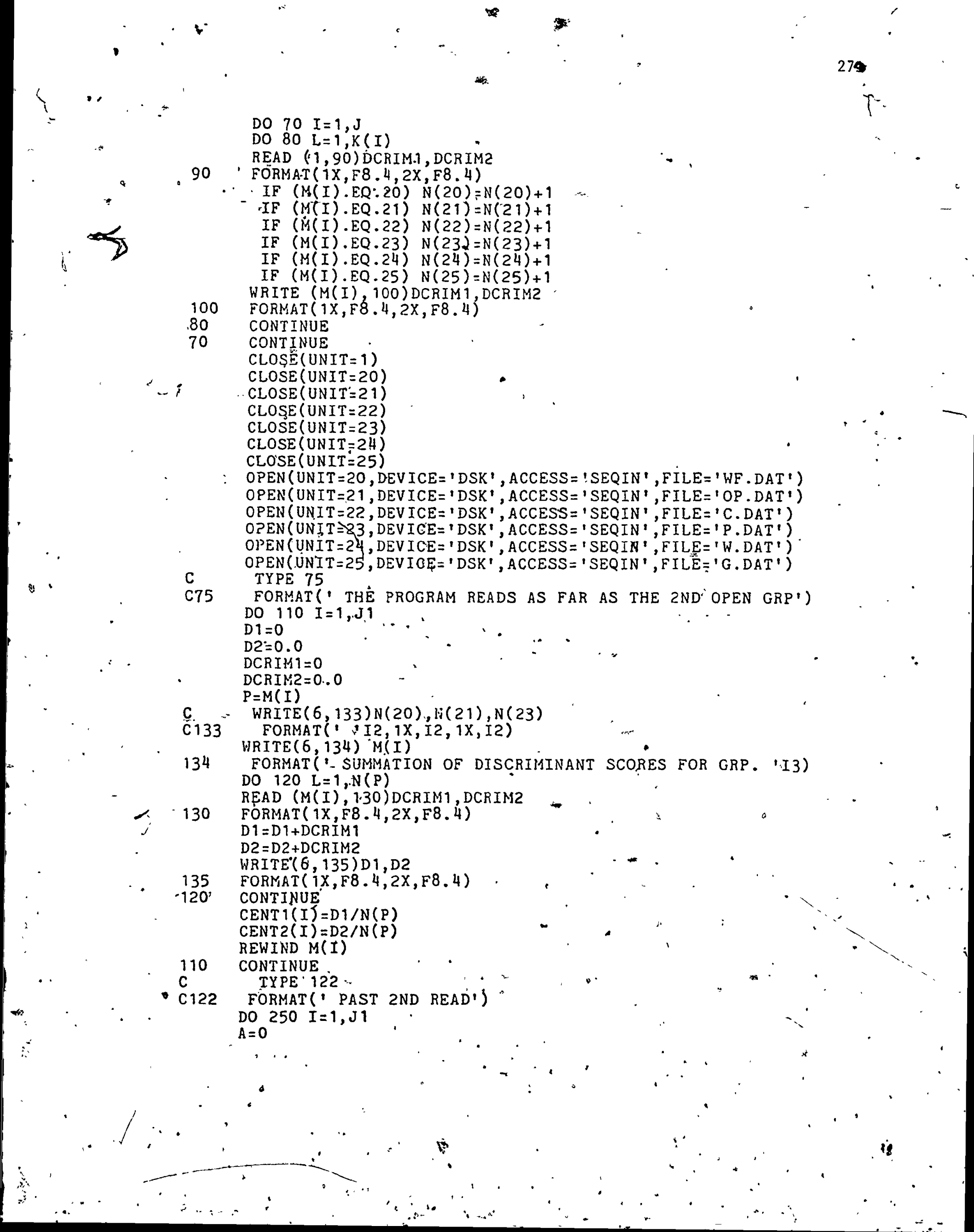




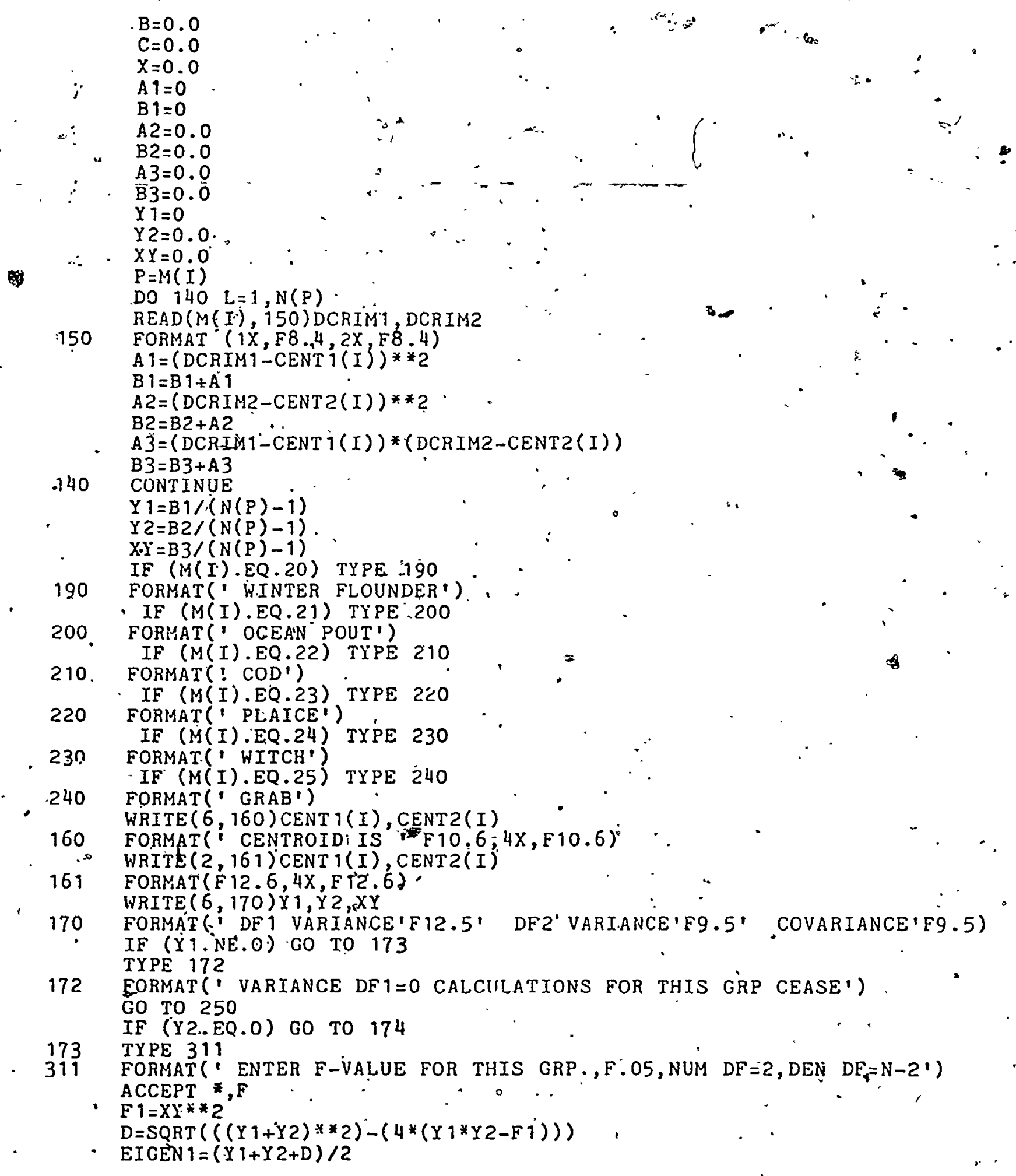




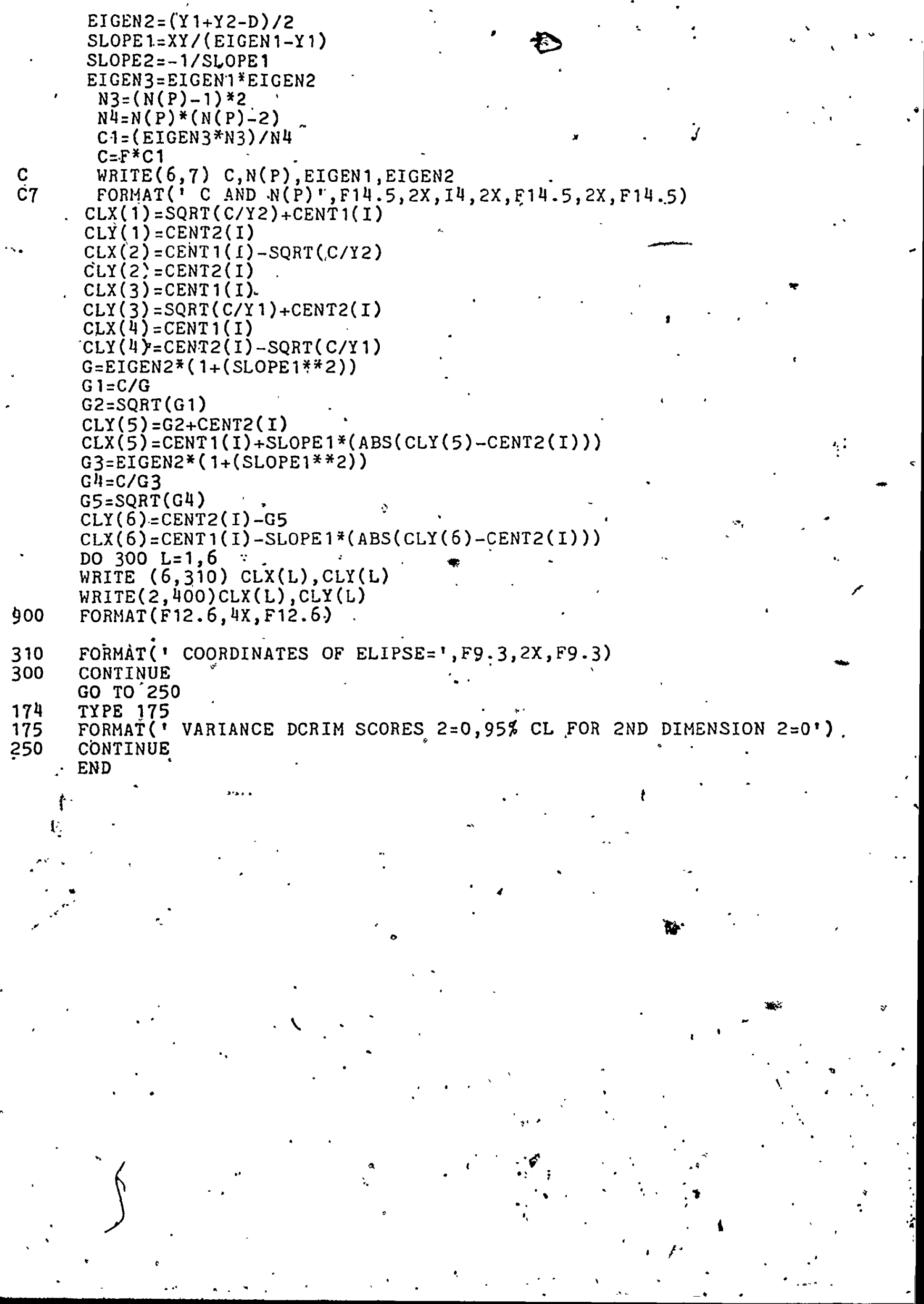




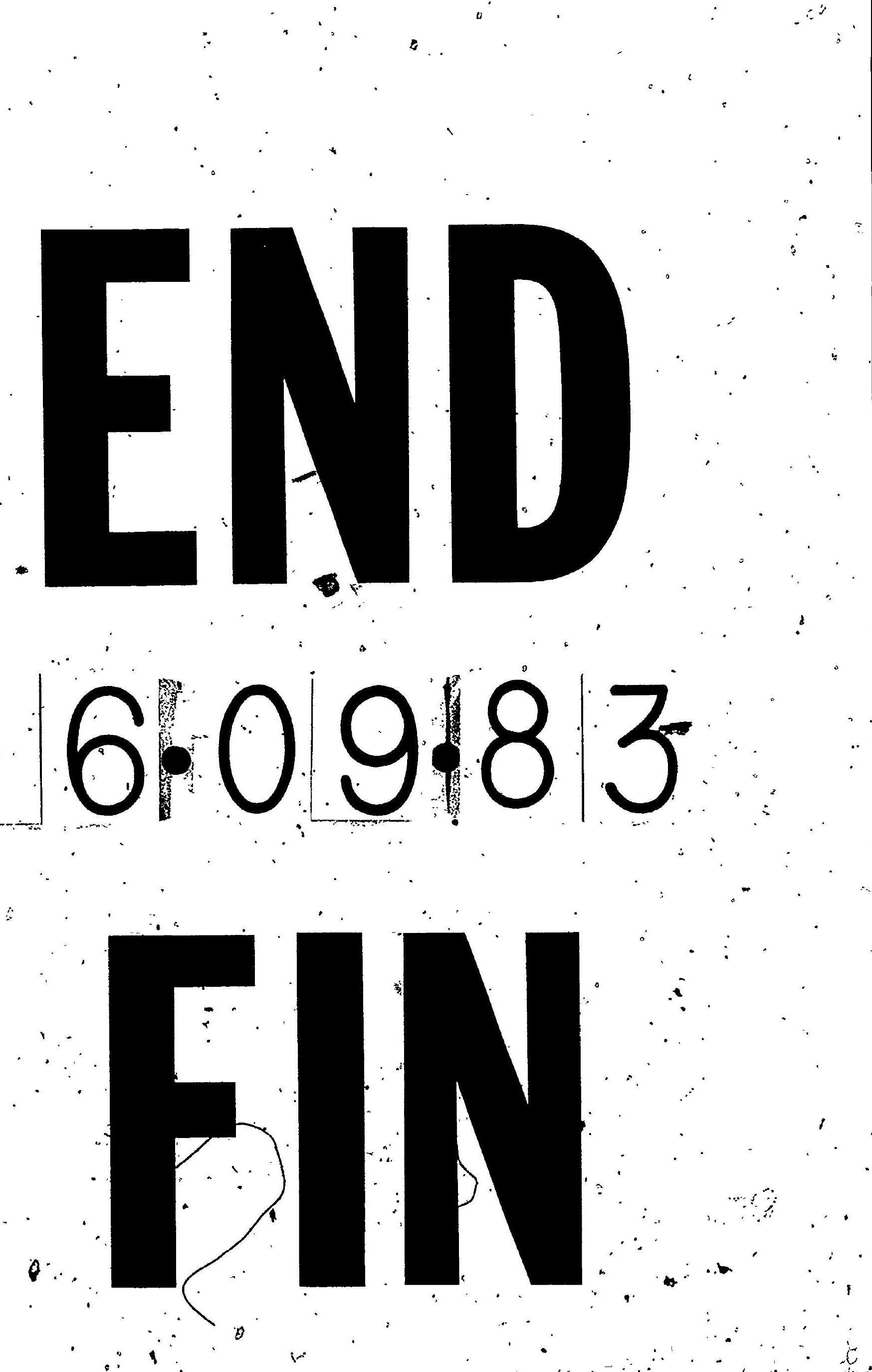

